SOFÍ A ISABEL TERÁN CÁCERES

\title{
RACIONALIZAÇÃO DE USO DE ENERGIA NA FLORICULTURA DA REGIÃO NORTE DO EQUADOR
}

Dissertação apresentada ao Programa Interunidades de Pós-Graduação em Energia (IEE-USP, EPUSP, FEA-USP, IFUSP) da Universidade de São Paulo para obtenção do título de Mestre em Energia.

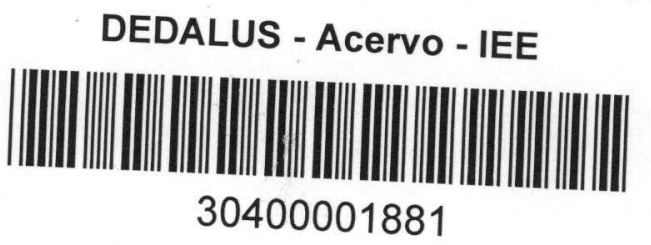

São Paulo

1994 


\section{SOFÍA ISABEL TERÁN CÁCERES}

\section{RACIONALIZAÇÃO DE USO DE ENERGIA NA FLORICULTURA DA REGIÃO NORTE DO EQUADOR}

Dissertação apresentada ao Programa Interunidades de Pós-Graduação em Energia (IEE-USP, EPUSP, FEA-USP, IFUSP) da Universidade de São Paulo para obtenção do título de Mestre em Energia.

Área de Concentração: Energia

Orientador:

Prof. Dr. Ildo Luis Sauer 
À minha família 


\section{A GRADECIMENTOS}

Ao professor Ildo Luis Sauer por sua orientação e sugestões na elaboração deste trabalho.

À International Energy Initiative (IEI) pelo apoio financeiro.

À Empresa Eléctrica Regional Norte S.A. (EMELNORTE S.A) de Equador pela minha liberação e pelos recursos dispostos para a realização deste trabalho.

Ao Instituto Ecuatoriano de Electrificación (INECEL) de Equador por facilitar a informação necessária para este trabalho.

A Alessandro Barginhi e a sua esposa Laura, meu profundo agradecimento pela amizade, ajuda e apoio permanente que recebi deles.

A todas as pessoas e instituições que de uma ou outra forma colaboraram na realização desta dissertação. 


\section{SUMÁRIO}

Página

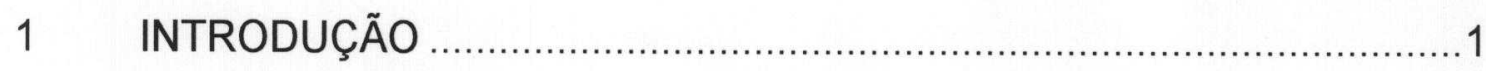

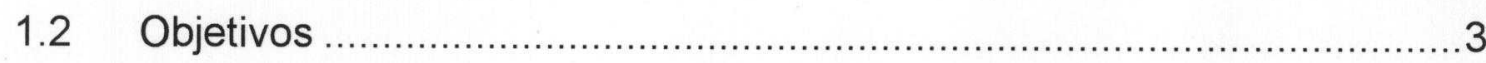

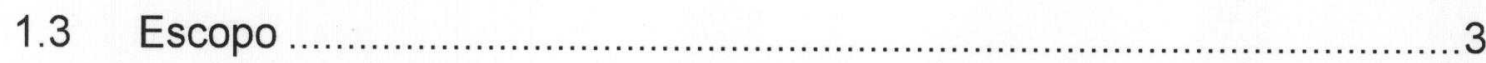

2 REVISÃO BIBLIOGRÁFICA SOBRE O EFEITO DA

LUZ NO CULTIVO DE FLORES, SISTEMAS DE

IRRIGAÇÃO E CÂMARAS DE REFRIGERAÇÃO

2.1 O EFEITO DA LUZ NO CULTIVO DE FLORES ......................................

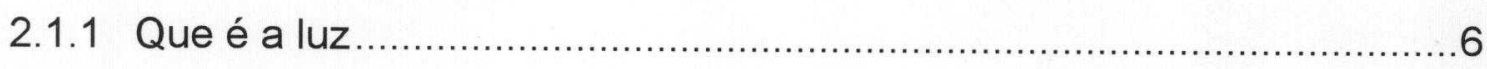

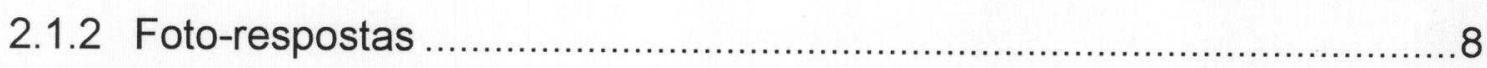

2.1.3 Fatores limitantes do crescimento das plantas .....................................13

2.1.4 Medição da energia radiante nas plantas ..............................................14

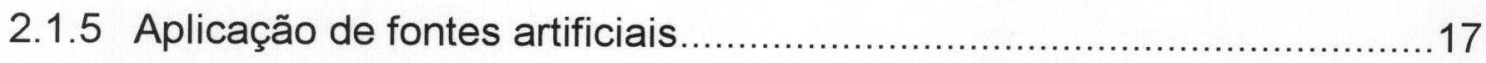

2.1.6 Tipos de fontes de luz artifical para cultivo de flores ...........................19

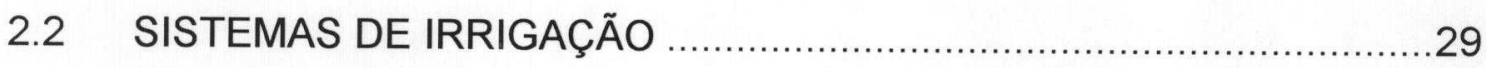

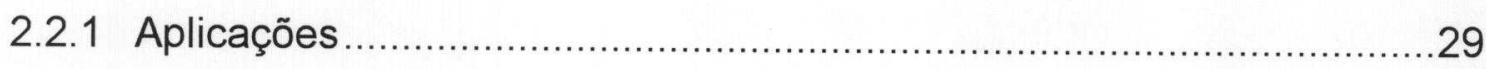

2.2.2 Componentes do sistema de irrigação por gotejo ....................................30

2.2.3 Princípios básicos do método de irrigação por gotejo.............................35

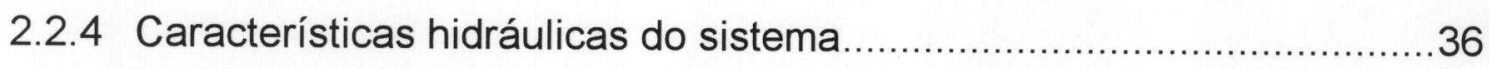

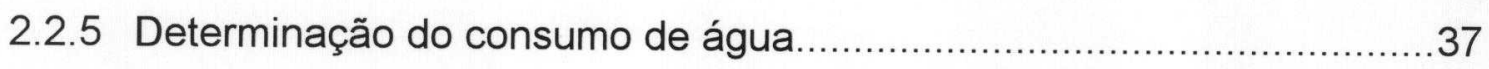

2.2.6 Eficiência do sistema de irrigação............................................................39

2.2.7 Benefício e dificuldades da irrigação por gotejo ...................................40

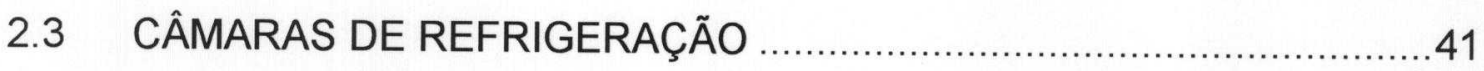


2.3.1 Cuidados básicos das flores dentro da câmara ....................................41

2.3.2 Características técnicas da instalação da câmara ................................4

3 CARACTERIZAÇÃO DA REGIÃO NORTE DA SERRA EQUATORIANA

3.1 CARACTERÍSTICAS CLIMÁTICAS ....................................................45

3.2 HISTÓRICO DA PRODUÇÃO DE FLORES .........................................4 48

3.3 ASPECTOS ASSOCIADOS COM A PRODUÇÃO DE FLORES ............50

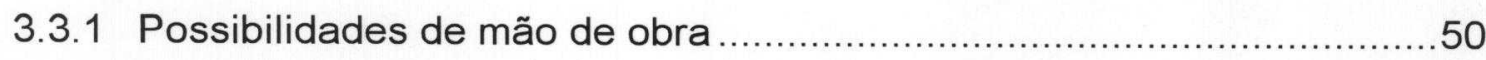

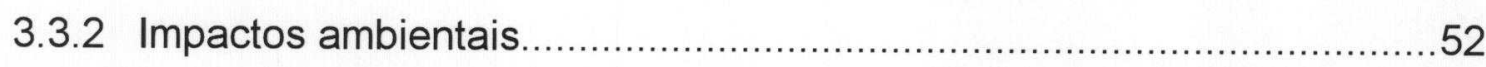

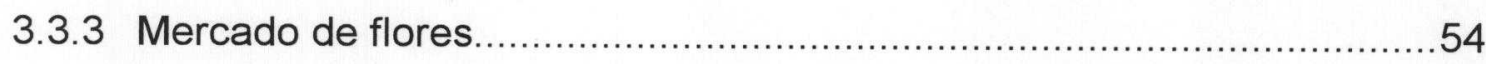

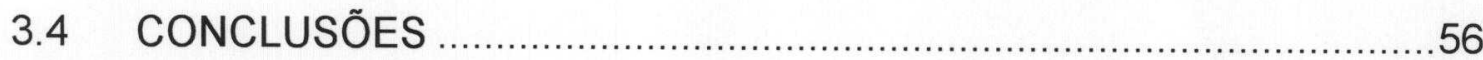

4 RELAÇÃO DO SETOR AGROINDUSTRIAL COM A CONCESSIONÁRIA DE ENERGIA

4.1 DEMANDA E CONSUMO DE ENERGIA …….......................................

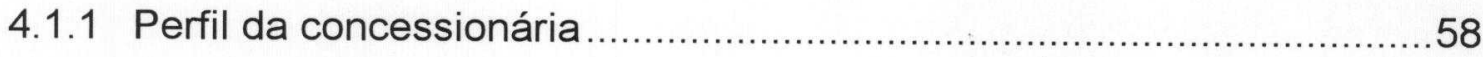

4.1.2 Participação do setor de cultivo de flores na demanda e consumo de energia...... 60

4.1.3 Comportamento do consumo agro industrial na curva

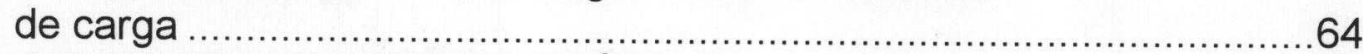

4.2 QUALIDADE DO SERVIÇO ELÉTRICO

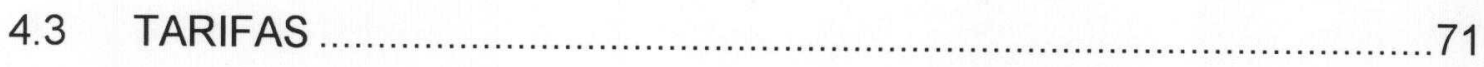

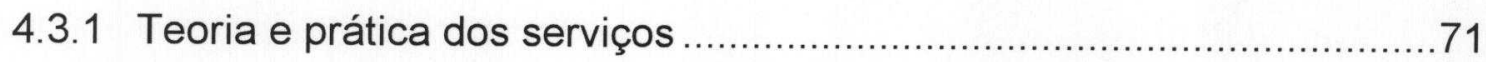

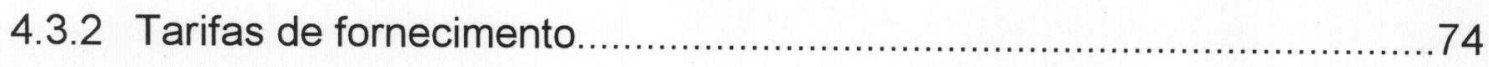

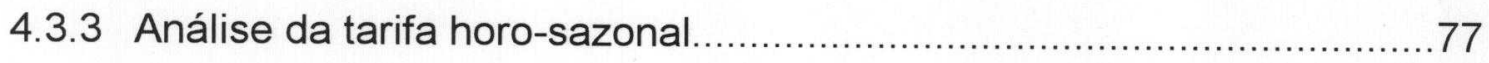

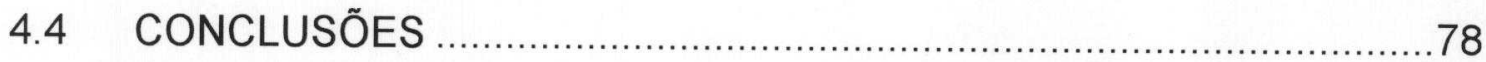


5 APRESENTAÇÃO DA PESQUISA DE CAMPO …................................8

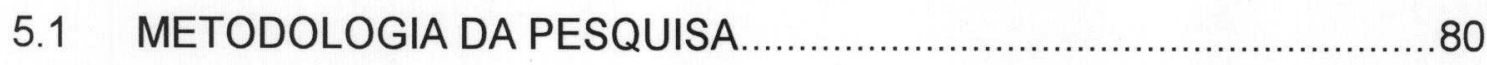

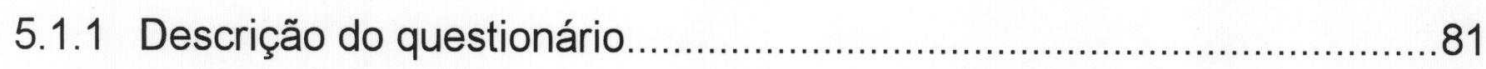

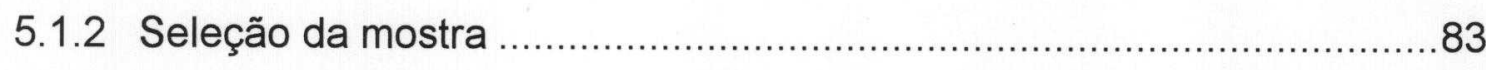

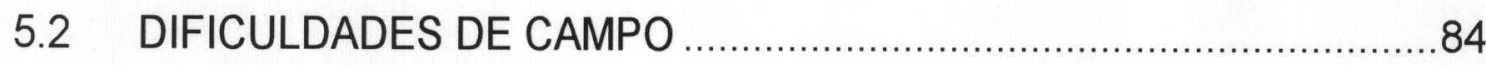

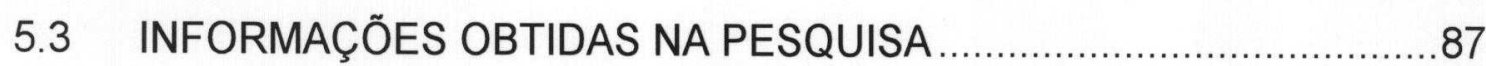

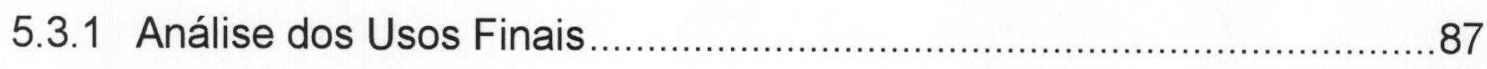

5.4 RESULTADOS OBTIDOS A PARTIR DA PESQUISA …........................95

5.4.1 Balanço energético, por uso final e por tipo de cultivo ..........................96

5.4.2 Comparação da energia calculada e energia registrada .....................104

5.4.3 Comparação da potência calculada e a potência contratada ...............105

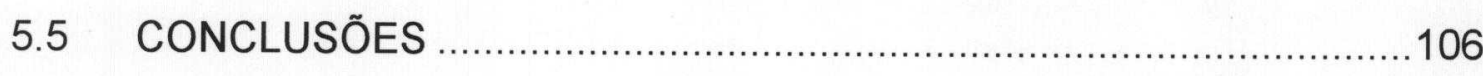

6 ANÁLISE DOS USOS FINAIS POR PROCESSO PRODUTIVO

6.1 SEQUÊNCIA DOS PROCESSOS PRODUTIVOS POR

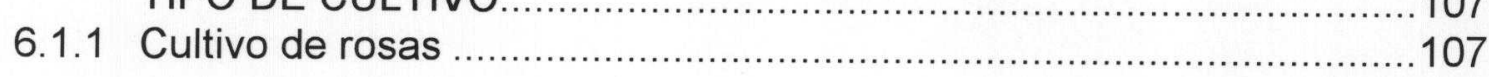

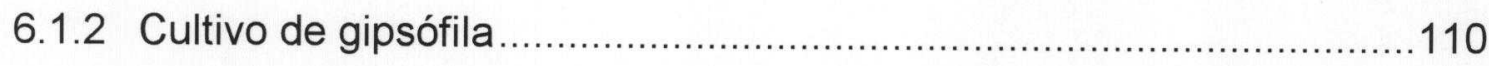

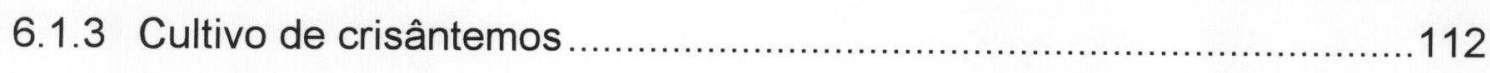

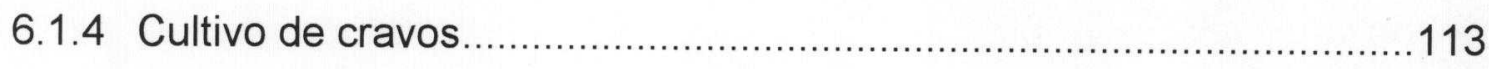

6.2 MEDIDAS DE RACIONALIZAÇÃO POR USO FINAL ……...................114

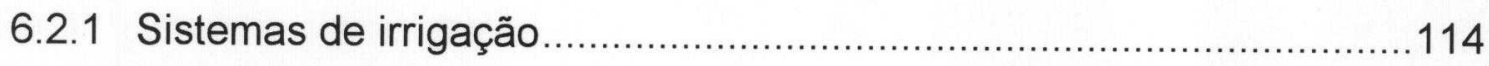

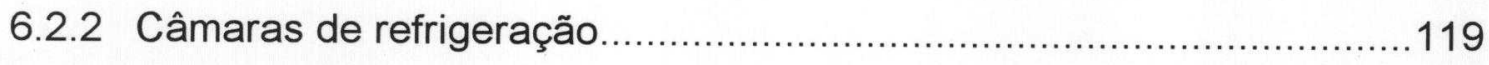

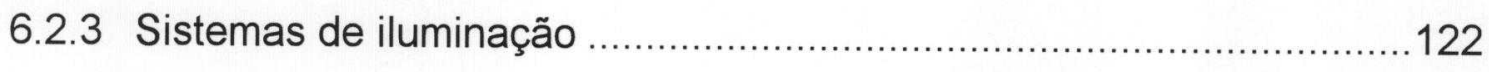

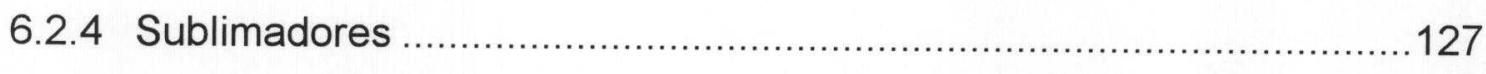

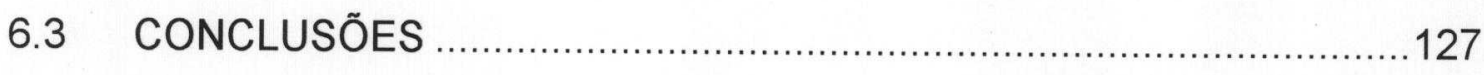




\section{AVALIAÇÃO ECONÔMICA E FINANCEIRA}

\subsection{AVALIAÇÃO FINANCEIRA DA TROCA DE LÂMPADAS} POR HECTARE DE CULTIVO DE FLORES

ANEXOS

Anexo A: CARACTERÍSTICAS DAS LÂMPADAS POWER

FLOWER E A VAPOR DE SÓDIO

Anexo B: MAPAS 143

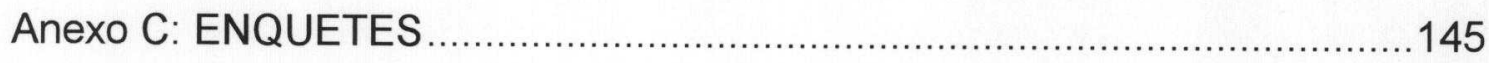

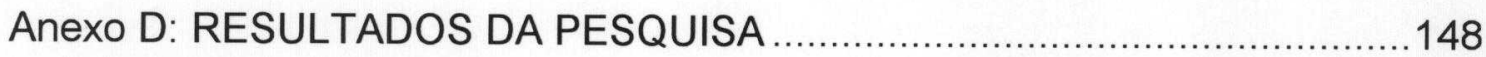

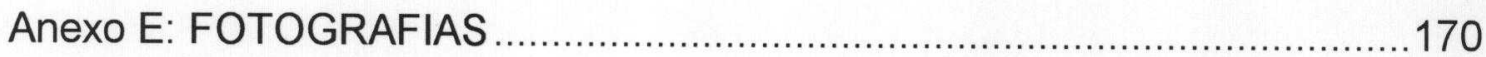




\section{LISTA DE FIGURAS}

Figura

Descrição

Página

2.1 Espectro electromagnético 7

2.2 Curvas de foto-respostas das plantas e visão

2.3 Fatores que influem no crescimento das plantas

2.4 Eficiência de uma lâmpada a vapor de sódio a alta pressão

Setores de consumo de EMELNORTE no ano 1993

Setor Industrial EMELNORTE no ano 1993

Consumo de energia para flores (1989-1993)

Demanda de potência (1989-1993) para o cultivo de flores

Curva circuito Pedro Moncayo - Curvas de carga por uso final

Curva de carga EMELNORTE - Curvas de carga por

uso final

5.1 Disposição física das lâmpadas incandescentes no cultivo de flores.

Ciclos liga/desliga das lâmpadas incandescentes.

5.3 Disposição física das lâmpadas a vapor de sódio no cultivo de flores.

Consumo de energia por uso final por hectare de cultivo de rosas

5.5 Consumo de energia no cultivo de gipsófila iluminado com lâmpadas incandescentes

5.6 Consumo/hectare de gipsófila lluminado com lâmpadas a vapor de sódio

5.7 Consumo de energia por uso final por hectare no cultivo de cravos

5.8 Consumo de energia por uso final por hectare de vários tipos de cultivo 


\section{LISTA DE TABELAS}

Tabela

Descrição

Página

2.1 Relação das unidades de radiometria e fotometria..........................15

3.1 Área do cultivo de flores por cantão .............................................48

3.2 Número de agroindústrias na região norte......................................49

3.3 Dados de população da região norte ..............................................51

3.4 Mão de obra empregada na produção de flores ...............................51

4.1 Número de consumidores por setores de consumo ........................59

4.2 Consumos parciais do setor Industrial no ano 1993 .......................61

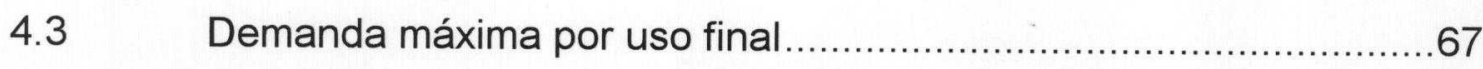

5.1 Número de agroindústrias por faixa de consumo ...........................84

7.1 Características das alternativas de iluminação para os cultivos ....130

7.2 Custos do investimento de lâmpadas, rede e acessórios ..............131

7.3 Período de vida útil dos elementos utilizados na instalação do sistema de iluminação

7.4 Custo do ciclo de vida anualizado CCVA do investimento e custo da energia economizada CEE

\section{Tabelas dos Anexos}

D.1 Cultivo de rosas: Dados gerais

D.2 Cultivo de rosas: Cálculo da potência contratada e energia

média mensal por hectare e por funcionário

D.3 Cultivo de rosas: Sublimadores

D.4 Cultivo de rosas: Sistema de irrigação.

D.5 Cultivo de rosas: Câmara de refrigeração 
D.6 Cultivo de rosas: Escritórios e serviços gerais 152

D.7 Cultivo de rosas: Comparação energia calculada, com a energia média mensal registrada. 153

D.8 Cultivo de rosas: Comparação da potência calculada, com a potência contratada.

D.9 Cultivo gipsófila: Dados gerais 154

D.10 Cultivo gipsófila: Cálculo da potência contratada e energia média mensal por hectare e por funcionário

D.11 Cultivo gipsófila: lluminação do cultivo 155

D.12 Cultivo gipsófila: lluminação sala de abertura 156

D.13 Cultivo gipsófila: Sistema de irrigação 157

D.14 Cultivo gipsófila: Câmaras de refrigeração. 157

D.15 Cultivo gipsófila: Escritórios e serviços gerais

D.16 Cultivo gipsófila: Comparação energia calculada, com a energia média mensal registrada

D.17 Cultivo gipsófila: Comparação da potência calculada, com a potência contratada 158

D.18 Cultivo cravos: Dados gerais 159

D.19 Cultivo cravos: Cálculo da potência contratada e energia média mensal por hectare e por funcionário

D.20 Cultivo cravos: Sistema de irrigação 160

D.21 Cultivo cravos: Câmaras de refrigeração 160

D.22 Cultivo cravos: Escritórios e serviços gerais. 160

D.23 Cultivo cravos: Comparação energia calculada, com a energia média mensal registrada. 
D.24 Cultivo cravos: Comparação da potência calculada, com potência contratada.

D.25 Cultivo várias espécies: Dados gerais 162

D.26 Cultivo várias espécies: Cálculo da potência contratada e energia média mensal por hectare e por funcionário 162

D.27 Cultivo várias espécies: lluminação do cultivo 163

D.28 Cultivo várias espécies: Iluminação sala de abertura 164

D.29 Cultivo várias espécies: Sublimadores 165

D.30 Cultivo várias espécies: Sistema de irrigação 166

D.31 Cultivo várias espécies: Câmaras de refrigeração. 167

D.32 Cultivo várias espécies: Escritórios e Serviços gerais 168

D.33 Cultivo várias espécies: Resistências. 168

D.34 Cultivo várias espécies: Comparação de energia calculada, com a energia média mensal registrada 169

D.35 Cultivo várias espécies: Comparação da potência calculada, com a potência contratada 169 


\section{RESUMO}

Esta dissertação analisa a situação atual e as perspectivas de melhoramento da eficiência energética no cultivo de flores da região norte do Equador.

Foi realizada uma pesquisa de campo, caracterizando o uso da energia elétrica para esse subsetor. Os usos finais identificados foram: irrigação, iluminação, sublimadores, câmaras de refrigeração e serviços gerais.

Além das características elétricas foram pesquisados dados sócio-econômicos, com a finalidade de avaliar de forma global a participação das agroindústrias na região.

Os resultados deste estudo mostram a grande conveniência de se utilizar tecnologias mais eficientes na iluminação devotada para o cultivo de flores. Também são apresentadas recomendações na operação dos sistemas de irrigação e câmaras de refrigeração.

As medidas de racionalização sugeridas neste trabalho visam o benefício econômico não apenas das agroindústrias mas também da concessionária e da sociedade. 


\begin{abstract}
This report analises the present situation and the improvement perspectives of energy efficiency in the flower culture in Northern Region of Equador.

A field research was carried out in order to charaterize the use of electric power by this subsetor. The end use identified were: irrigation, lighting, sublimation, refrigeration (chambers) and general services.
\end{abstract}

Socio-economic data were researched, beyond the eletrical charateristics, to evaluate the global share of the agro-industries in the region.

The results of this study show the great convenience of using more efficient technologies in the lighting of flower cultures and also presents recomendation to the operation of the irrigation and refrigeration (chambers) systems.

The racionalization measures sugested in this work view not only the economic benefit of the agro industrives but also of the society and the utility. 


\section{INTRODUÇÃO}

O tema deste estudo está definido como a análise do potencial de racionalização de energia no setor agroindustrial de cultivo de flores da Sierra Norte do Equador.

A escolha deste tema surgiu da necessidade de aprofundar a problemática que apresenta 0 subsetor floricultor, bastante variado e atualmente num acelerado crescimento, para assim compreender quais são suas necessidades.

De outro lado para a concessionária de energia é conveniente conhecer o comportamento dos consumos e demada de potência, com a finalidade de orientar aos consumidores a otimizar o uso da energia. Desta maneira a concessionária realizará o planejamento da demanda ao menor custo, sem comprometer maiores recursos financeiros.

O desenvolvimento do setor de flores envolve vários fatores, como são: sociais, ecomômicos e o atendimento do serviço elétrico. Do ponto de vista do atendimento à demanda de potência e energia por parte da concessionária é possível indicar o seguinte:

- O setor do cultivo de flores representa hoje mais de $22 \%$ do consumo industrial da concessionária, a sua participação é crescente como expressa a taxa de crescimento do consumo, que nos últimos 5 anos apresenta uma média de $63 \%$.

- As empresas agroindustriais se encontram distribuídas em cinco cantões da área da concessionária. Em dois cantões para $\circ$ atendimento aos consumidores foi preciso a construção de novos alimentadores e a restruturação dos existentes. 
- Sendo estas agroindústrias localizadas nas regiões rurais, causa uma descentralização da demanda, anotando um aspecto importante que viabiliza o processo de extensão da eletrificação rural, que em geral é deficitária. Portanto este setor tem grande interesse econômico e social para a concessionária.

- 0 aumento da ocupação, especialmente feminina, como mão de obra das agroindústrias, está tendo reflexos positivos sobre a economia da região, gerando inclusive um maior consumo residencial rural.

Para a concessionária a difusão das agroindústrias de flores tem sido positiva, ela concorda com o suporte ao crescimento deste setor e tem dedicados seus recursos financeiros para priorizar melhoras no sistema de distribuição que atinge a estes consumidores.

Para as agroindústrias contar com o serviço elétrico oportuno e eficiente é a base para a instalação de novas indústrias ou expansão das atuais. É de interesse dos produtores de flores dar o uso racional à energia e a suas instalações, sendo as principais razões as seguintes:

- Quase toda a produção deste setor é destinada para a exportação, portanto para um mercado altamente competitivo, (as flores entram em concorrência com a produção Norte Americana e com a Colombiana) onde uma redução de custos é um elemento que possibilita a expansão do mercado.

- É um setor que utiliza tecnologias bastantes sofisticadas, seja a nível agronômico de produção, seja a nível de conservação e transporte das flores, enquanto que o uso da energia não apresenta a mesma preocupação. Realizar o estudo do uso da energia pode contribuir para melhorar alguns dos processo produtivos.

A base do estudo foi uma pesquisa de campo realizada em janeiro 1994 nas agroindústrias de cultivo de flores na área de concessão da Empresa Elétrica 
Regional Norte (EMELNORTE). Dentro da pesquisa se realizou um cadastro das potências nominais dos equipamentos elétricos de cada agroindústria e a descrição dos modos de uso. Paralelamente foram colhidos os dados sócio econômicos e as variáveis agronômicas dos cultivos.

Tendo os dados, após uma depuração final das enquetes, se procedeu à normalização dos dados, calculando todas as variáveis como demanda, e consumo por uso final por hectare cultivado, obtendo desta forma os dados paramétricos comparáveis de uma agroindústria para outra.

Uma vez que os dados foram depurados e normalizados (expressos por hectare), se procedeu à interpretação dos mesmos.

O tema estudado durante seu desenvolvimento se apresentou bastante complexo. O cultivo de flores em geral, é visto como uma atividade extremamente simples, embora, na verdade, ele envolve uma tecnologia sofisticada, para os tratos agronômicos dos cultivos, para proporcionar um produto altamente competitivo nos mercados internacionais.

Para entender claramente os diferentes processos utilizados foi necessário entrar nos detalhes da resposta fotoperiódica das plantas à variação do comprimento do dia e analisar as características de luminância dos diferentes tipos de lâmpadas.

Por outro lado todas as fases do cultivo precisam do uso da energia, para a irrigação, para os tratamentos fito-sanitários, para o processo de conservação, em cada uma destas fase envolvem parâmetros fito-botânicos que devem ser perfeitamente conhecidos para otimizar o uso da energia. 


\subsection{OBJETIVOS}

Para cumprir com o estudo, propõe-se dois objetivos:

1.- Avaliar os consumos de energia elétrica para cada uso final utilizado no processo agroindustrial do cultivo de flores.

2.- Analisar técnica e economicamente as alternativas de substituição dos equipamentos utilizados atualmente, por equipamentos eficientes, ou orientar as medidas de racionalização de energia a ser implementadas nas agroindústrias.

\subsection{ESCOPO}

O número de hectares dedicados ao cultivo de flores na região em estudo ultrapassa os 230 hectares (até janeiro 1994). Comparando com as cifras proporcionadas na publicação de HEUSSLER(1991) e projetando até dezembro 1993, a superfície desta região representa o $50 \%$ da área que em todo o país está destinada para tal atividade. Apesar do estudo estar restrito para uma região, ele pode ser difundido para outras regiões, porque tem características climáticas similares e os processos produtivos correspondem ao mesmo padrão.

Os usos finais identificados em todas as agroindústrias são equipamentos para: o sistema de irrigação, câmara de refrigeração, iluminação (com lâmpadas incandescentes e a vapor de sódio), sublimadores e escritórios e serviços gerais. As medidas de racionalização proposta no estudo são para os 4 usos, excluindo os escritórios e serviços gerais porque a sua participação no consumo no global da agroindústria é muito baixo. 


\section{REVISÃO BIBLIOGRÁFICA SOBRE O EFEITO DA LUZ NO CULTIVO DE FLORES, SISTEMAS DE IRRIGAÇÃO E CÂMARAS DE FRIO.}

\subsection{O EFEITO DA LUZ NO CULTIVO DE FLORES}

A energia radiante torna possível a vida dos seres animais e vegetais. Para o desenvolvimento das plantas a luz é um dos fatores principais: somente em presença de luz realiza-se o processo de fotossíntese.

Luz normalmente é sinônimo de espectro visível ao olho humano. Nas plantas nem todo o espectro visível ocasiona respostas físico-químicas. Elas apresentam maior sensibilidade a alguns comprimentos de onda dentro e fora do espectro visível, o que motiva a expor os conceitos básicos relacionados com os efeitos que a energia radiante causa nas plantas, tanto as caraterísticas de absorção quanto os períodos de tempo que as plantas podem permanecer expostas às fontes de luz.

De maneira particular, para o cultivo de flores a luz é um fator que pode ser manipulado mediante a utilização de fontes artificiais, sendo importante conhecer as vantagens e desvantagens que oferecem os diferentes tipos de lâmpadas. Atualmente os fabricantes dos elementos de iluminação desenvolvem lâmpadas mais eficientes e apropriadas para o cultivo de flores.

Aproveitando os benefícios da luz artificial para acelerar o crescimento e florescimento de certas espécies de flores, os floricultores podem ampliar sua produção e manter o produto nos mercados consumidores em qualquer época do ano, independentemente das condições adversas de luz e temperatura decorrentes das estações do ano que poderiam impedir o cultivo dessas variedades. 


\subsubsection{QUE É A LUZ}

A luz é uma parte pequena do espectro de radiação eletromagnética, compreendida na faixa dos comprimentos de onda, desde $400 \mathrm{~nm}$ até $700 \mathrm{~nm} 1$. Nestes comprimentos de onda é possível estimular os nervos ópticos dos olhos humanos, produzindo a sensação visual. Dentro do espectro visível os comprimentos de onda são identificados pela cor da luz: violeta aproximadamente em $400 \mathrm{~nm}$, azul/verde em torno de $500 \mathrm{~nm}$, amarelo/laranja contíguo a $600 \mathrm{~nm}$ e vermelho próximo a $700 \mathrm{~nm}$, como se pode observar na Figura. 2.1 Os comprimentos de onda fora do espectro visível não são transformados pelos receptores da pupila humana em imagem visível. A sensibilidade máxima do olho humano ocorre a $555 \mathrm{~nm}$, mas este valor varia de pessoa a pessoa. Tem-se uma curva média para o olho compreendida na faixa de $400 \mathrm{~nm}$ até $700 \mathrm{~nm}$, Figura. 2.2

Para cada comprimento de onda o conteúdo de energia é diferente, a luz pode ser considerada como um fluxo de partículas chamadas fótons. Os fótons têm energia discreta segundo o comprimento de onda de onde provenham. Conforme a lei de Planck $\left(E=h{ }^{*} f\right)$, a energia de distribuição espectral $(E$, em J), é igual ao produto da frequência da radiação $\left(\mathrm{f}, \mathrm{em} \mathrm{s}^{-1}\right)$, pela constante de Planck $\left(\mathrm{h}=6.62 * 10^{-34} \mathrm{~J} * \mathrm{~s}\right)$. O conteúdo de energia incrementa-se para frequências maiores, portanto para comprimentos de onda menores; assim um foton de luz azul contém uma energia maior que um de luz vermelha., PHILIPS (1989).

$1 \mathrm{~nm}$ ou nanometro é um milionésimo do milimetro e é igual $10^{-9}$ metros 
Figura. 2.1 ESPECTRO ELETROMAGNÉTICO

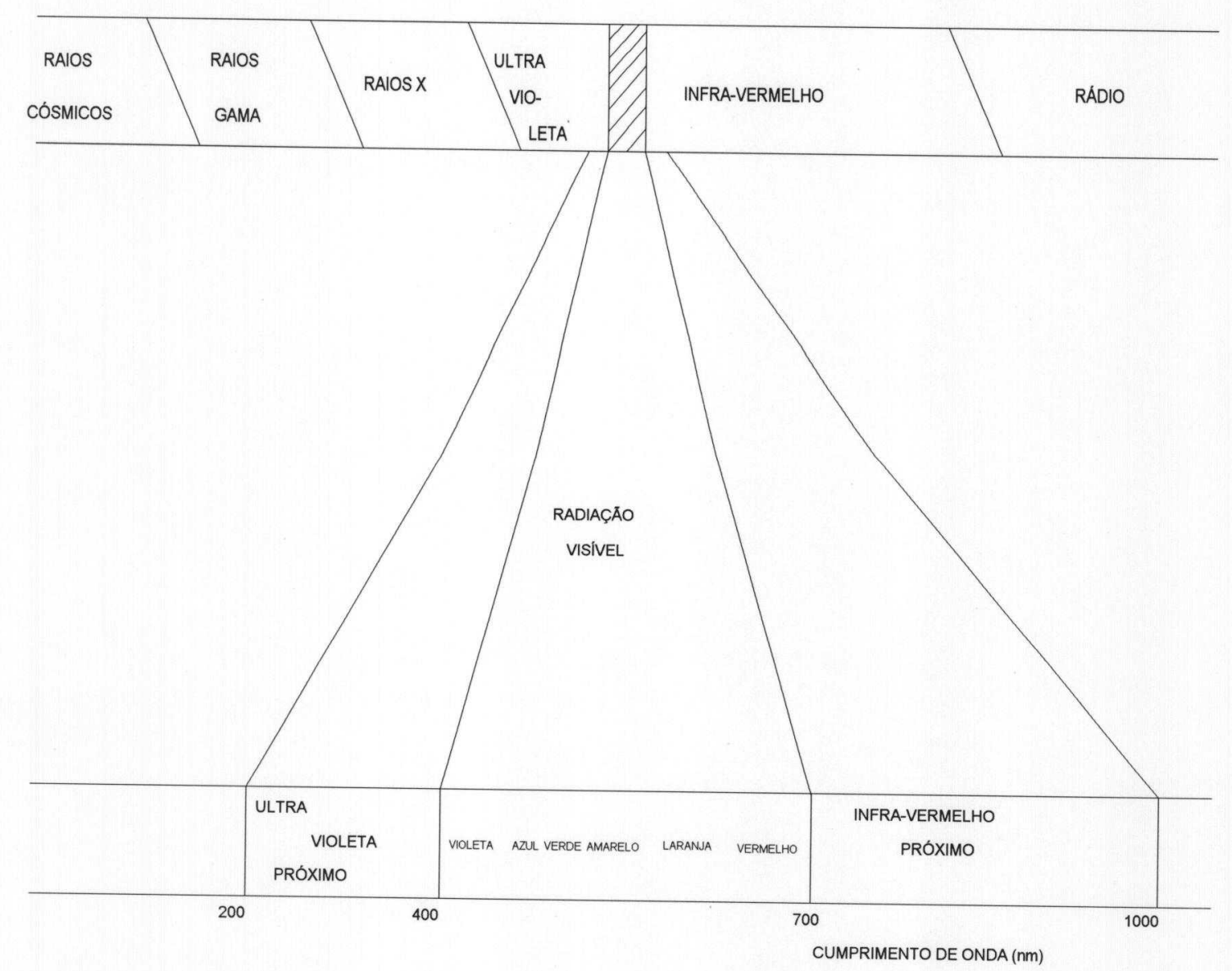

A sensibilidade das plantas à luz visível não é a mesma registrada pelos nervos ópticos dos seres humanos. A avaliação do efeito da luz aplicada nas plantas se realiza observando o desenvolvimento que elas adquirem no crescimento, na formação, florescimento, etc.

Quando a planta absorve a radiação luminosa, provoca aceleração das reações químicas que normalmente realizam-se lentamente. A luz utilizada como energia primária desencadeia uma série de reações.

O termo luz, nas plantas, inclui radiações invisíveis aos olhos humanos. Além do aproveitamento da luz para obter as foto-respostas, acontecem respostas de caráter biológico fora da faixa dos comprimentos de onda da luz visível, como 
por exemplo o efeito dos germicidas, que ocorrem nos comprimentos de onda de $290 \mathrm{~nm}$ até $300 \mathrm{~nm}$.

\subsubsection{FOTO-RESPOSTAS}

A energia radiante nas plantas provoca respostas, tais como: fotossíntese, fototropismo, fotomorfogênese, sendo a mais importante dentro da resposta de fotomorfogênese a resposta ao fotoperiodismo. Cada uma destas foto-respostas, cumprem funções particulares no desenvolvimento das plantas, como explica ILLUMINATING ENGINEERING SOCIETY OF NORTH AMERICA (IES) 1981.

- Fotossíntese

A fotossíntese é o processo no qual a energia radiante é convertida em energia química necessária para a síntese dos componentes orgânicos, essenciais para o crescimento da planta.

CANHAM (1966) diz que o processo de fotossíntese pode ser representado como uma simples reação:

$$
\mathrm{CO}_{2}+\mathrm{H}_{2} \mathrm{O} \text { - energia }
$$

Na prática o processo é o resultado de uma complexa cadeia de reações químicas, as quais ocorrem em cada célula da planta.

CONTI (1991) descreve o processo: a luz absorvida pelas folhas verdes fornece à planta a energia necessária para converter o $\mathrm{CO}_{2}$ e a água em clorofila; a molécula da água é aberta em cada um de seus elementos, liberando o oxigênio para $\circ$ ar e ० hidrogênio combina-se com o gás carbônico do ar, formando moléculas complexas que são os hidratos de carbono, principais componentes da 
clorofila; além disso ocorre a formação de açúcares e amidos. As moléculas de açúcar são armazenadas para satisfazer as necessidades de crescimento orgânico. No processo de fotossíntese ocorrem também manifestações térmicas, a temperatura da planta é um fator sensível no processo.

O oxigênio formado como subproduto da fotossíntese, é eliminado para a atmosfera, sendo usado na respiração das plantas e animais, na combustão, etc. As folhas emitem oxigênio quando a fotossíntese excede à respiração (em períodos de luz). Quando o nível de emissão de oxigênio diminui até o ponto onde os carbohidratos produzidos são usados na respiração, a reação fotossintética é zero e não há emissão de oxigênio: este fenômeno é chamado ponto de compensação. As reservas de carbohidratos são usadas pelas plantas em períodos de escuridão, par suprir a energia necessária aos processos vitais.

O processo de fotossíntese, é a maneira pela qual a luz induz o crescimento das plantas. A formação da clorofila é possível pela absorção e conversão da luz, ocasionando mudanças na estrutura molecular; tal processo é conhecido como síntese da clorofila.

Além da luz absorvida para o processo da fotossíntese, a luz produz mudanças químicas, aproveitadas pela planta para seu crescimento. Segundo DOWNS (1975), a luz é essencial para a formação de pigmentos, comanda a abertura dos estomatos, regula o relógio biológico interno, modifica o tamanho e forma da planta, tamanhos, formas e cores das folhas, o comprimento entrenó, a formação de flores e seus tamanhos, formas, fragrâncias e cores.

- Fototropismo

São os movimentos que a planta faz orientando-se na direção da fonte de luz. Esta foto-resposta é controlada pela absorção dos comprimentos de onda curta. Devido às mudanças na direção da fonte de luz as plantas apresentam 
respostas, tais como: curvatura do caule até a direção da fonte de luz, fecham as flores durante a noite e abrem durante o dia; esta resposta é conhecida como fotonastismo.

\section{- Fotomorfogênese}

É o controle do crescimento das plantas e está relacionado com a duração dos períodos de luz que elas recebem e com a densidade de fluxo radiante. São respostas à fotomorfogênese: fotoperiodismo (resposta aos períodos de luz e escuridão), germinação da semente, alongamento do caule e formação de pigmentos.

\section{Fotoperiodismo}

Está relacionada com a variação natural de duração relativa dos períodos de dia e noite: é o fator determinante da época de florescimento.

Segundo os botânicos (DOWNS 1975) dividem em três classes de plantas:

a- Plantas de dias curtos.- São as plantas nas quais o florescimento ocorre, ao existir uma redução do número de horas de sol, portanto o seu período de luz solar não ultrapassa um certo valor crítico.

b- Plantas de dias longos.- São as plantas cujo florescimento ocorre, quando aumenta o número de horas de luz solar, portanto florescem unicamente quando o período de luz solar ultrapassa um certo valor crítico.

c- Plantas de dia neutro.- Não são afetadas pelo número de horas de luz solar.

Esta caraterização, apesar de clássica na área da botânica, se aplica pouco ao clima do Equador, porque o número de horas de luz por dia é constante: a variação máxima do comprimento do dia é inferior a 20 minutos, nas diferentes 
estações, JONES (1992). Na região equatorial a iluminação artificial se aplica para modificar o dia padrão de 12 horas de luz diária. Assim:

- As plantas de dias curtos como os crisântemos, recebem durante o período vegetativo, uma complementação de luz durante um período de tempo, quando esta iluminação complementar é retirada, a planta "sente" que os dias se encurtam e inicia o processo de florescimento. O período de florescimento se dá porém com um dia de 12 horas. As plantas de dias curtos são sensiveis á redução da iluminação.

- As plantas de dias longos, como a gipsófila, recebem quando se quer induzir o florescimento, um aumento do número de horas de iluminação. O aumento do número de horas de luz induz o florescimento, começando o separar as gemas de flores. A partir deste momento a iluminação complementar pode ser suspensa, e a planta entrará em florescimento. Caso, a planta não receber iluminação complementar, ela tenderá a crescer vegetativamente, sem dar flores. As plantas de dias longos, são sensíveis ao aumento do período da iluminação.

CANHAM (1966) afirma que em certas espécies de plantas a sensibilidade ao fotoperiodismo depende da idade da planta, em tais espécies de plantas há uma fase juvenil na qual o crescimento é puramente vegetativo e não apresentam uma resposta ao florescimento até alcançar seu desenvolvimento, então a maior intensidade da luz fornecida à planta nesse tempo pode diminuir a fase juvenil e a absorção de energia radiante será somente para fotossíntese.

O processo de fotoperiodismo está influenciado pelo comprimento de onda da luz que a planta recebe: sob a luz vermelha e infravermelha a planta permanece no estado vegetativo e demora seu processo de florescimento; sob a luz ultravioleta e azul a resposta vegetativa da planta é fraca mas favorece o florescimento. 
As foto-respostas definidas, IES (1993), têm diferentes comportamentos dentro do espectro de respostas das plantas que compreende a faixa de $350 \mathrm{~nm}$ até $800 \mathrm{~nm}$. A Figura. 2.2 mostra, que as plantas apresentam maior sensibilidade nos comprimentos de onda de 400 até $500 \mathrm{~nm}$ para o fototropismo, de 600 até $700 \mathrm{~nm}$ para a fotomorfogênese, de 700 até $800 \mathrm{~nm}$ para a resposta inversa à fotomorfogênese. Em todo o espectro tem-se a presença da resposta à fotossíntese, esta curva média é bastante razoável para todo tipo de plantas com um desvio máximo da ordem de $5 \%$; a máxima sensibilidade para fotossíntese acontece aproximadamente em $675 \mathrm{~nm}$, como explica PHILIPS (1989). Pode-se observar que as foto-respostas das plantas são importantes onde as respostas da visão fotópica são mínimas.

Figura. 2.2 CURVAS DE FOTO-RESPOSTAS DAS PLANTAS E VISÃO

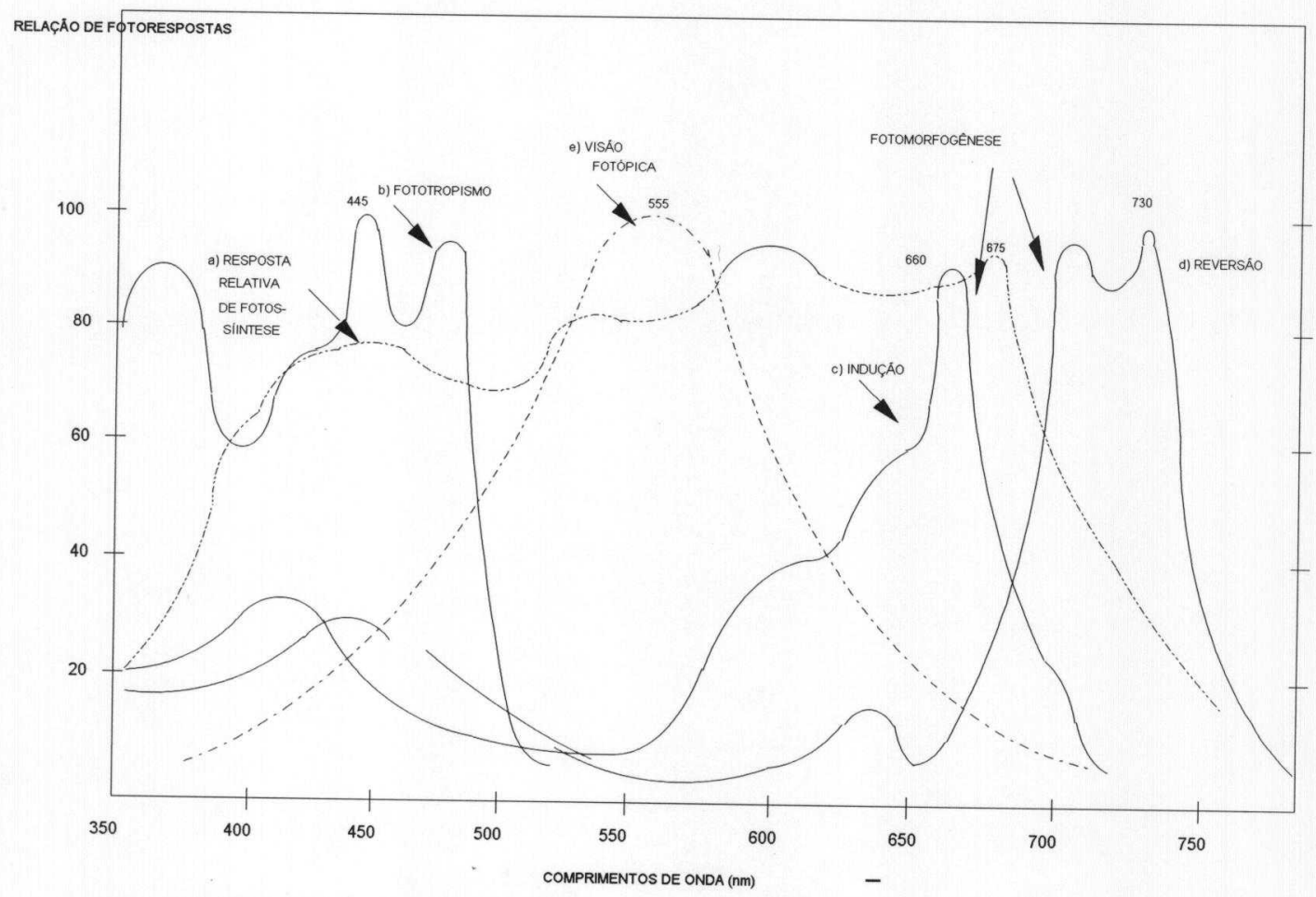
a) resposta relativa de fotossíntese, b) fototropismo
c) indução fotomorfogênese, d) inversão fotomofogenêse
e) visão fotópica. 


\subsubsection{FATORES LIMITANTES DO CRESCIMENTO DAS PLANTAS}

Outros fatores que também influenciam no crescimento das plantas são: água, nutrientes (sais minerais), temperatura e dióxido de carbono, que elas devem receber em quantidades ótimas para o melhor aproveitamento. A falta destes elementos limita o crescimento, IES (1981). Na Figura. 2.3 observa-se que bons níveis de fotossíntese são obtidos quando além de aumentar os níveis de iluminação, existem incrementos nas percentagens de $\mathrm{CO}_{2}$ e na temperatura. Estes princípios devem ser considerados ao se aplicar fontes artificiais de iluminação para acelerar o crescimento das plantas.

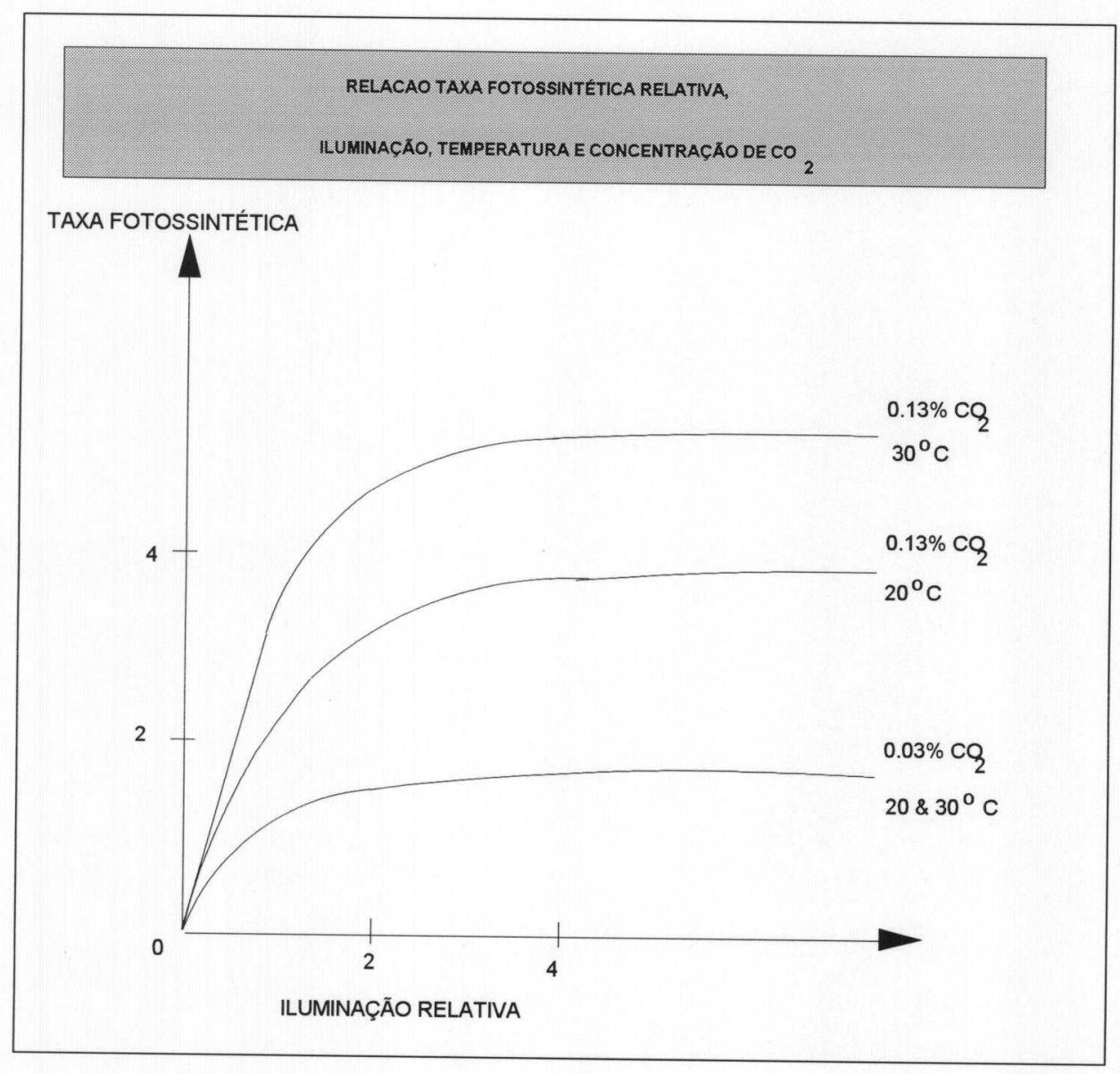

Fig. 2.3: FATORES QUE INFLUEM NO CRESCIMENTO DAS PLANTAS: TEMPERATURA, ILUMINAÇÃO RELATIVA E CO2 


\subsubsection{MEDIÇÃO DA ENERGIA RADIANTE NAS PLANTAS}

Para aplicar uma certa quantidade de luz às plantas é básico saber a quantidade de luz que elas necessitam e o tempo de luz natural disponivel, DOWNS (1975).

A quantidade diária de irradiação do sol que a Terra recebe, está expressa em energia por área e pelo tempo de incidência da luz solar, em Joule/cm² $\left(\mathrm{J} / \mathrm{cm}^{2}\right)$. A quantidade de radiação solar para uma localidade é função da latitude, altitude e condições climáticas da região. Quando o cultivo se faz dentro de estufa a quantidade de radiação no interior será afetada por um fator devido à transmissão da luz, que é da ordem de 0,7 para estufas novas e 0,3 para estufas sujas ou velhas.

De acordo com IES (1981) ao se referir à irradiação das plantas é necessário ter presente a diferença entre os conceitos de radiometria e de fotometria, assim como também as unidades correspondentes:

Energia radiante: é a energia emitida, transferida ou recebida em forma de radiação, em Joule (J) ou em watts.seg (W.s).

Energia luminosa: é a quantidade de luz que sensibiliza o olho humano, irradiada ou recebida num período de tempo, em lumen multiplicado por tempo, em lumen.segundo (Im.s).

Fluxo radiante: é a relação do fluxo de toda a energia desde uma fonte de radiação, em Joule por segundo (W).

Fluxo luminoso: é a relação de emissão de luz, derivado do fluxo radiante que sensibiliza o olho humano, expressado em lumen.

Irradiância: $\quad$ é a densidade de fluxo radiante incidente numa superfície ou a energia radiante recebida pela superfície em $\mathrm{W} / \mathrm{m}^{2}$. Nas 
plantas é considerada somente na parte do espectro visível.

Iluminância: é a densidade de fluxo luminoso incidente numa superfície, em lux.

Eficiência radiante: é a relação do fluxo de radiação total emitido por uma superfície de radiação, para a energia consumida. Para uma lâmpada é a relação de energia elétrica convertida em energia radiante.

Eficácia luminosa: é a relação do fluxo luminoso total emitido pela lâmpada para a potência.

$\mathrm{Na}$ Tabela 2.1, apresentam-se as unidades dos parâmetros antes mencionados, para radiometria e fotometria.

Tabela 2.1: RELAÇÃO DAS UNIDADES DE RADIOMETRIA E FOTOMETRIA

\begin{tabular}{|c|c|c|c|}
\hline \multicolumn{2}{|c|}{ RADIOMETRIA } & \multicolumn{2}{|c|}{ FOTOMETRIA } \\
\hline TERMOS & UNIDADES & TERMOS & UNIDADES \\
\hline $\begin{array}{l}\text { Energia radiante } \\
\text { Fluxo radiante } \\
\text { Irradiância } \\
\text { Eficiência } \\
\text { radiante }\end{array}$ & $\begin{array}{l}\text { Joule }(\mathrm{J}) \\
\text { Watts-seg }(\mathrm{W} . \mathrm{s}) \\
\text { Joule/seg }(\mathrm{J} / \mathrm{s}) \\
\text { Watts }(\mathrm{W}) \\
\text { Watts/m² }\left(\mathrm{W} / \mathrm{m}^{2}\right) \\
\\
(\mathrm{mW} / \mathrm{W})\end{array}$ & $\begin{array}{l}\text { Energia luminosa } \\
\text { Fluxo luminoso } \\
\text { Iluminância } \\
\text { Eficácia luminosa }\end{array}$ & $\begin{array}{l}\text { lumen-seg (Im.s) } \\
\text { lumen (Im) } \\
\text { lumen } / \mathrm{m}^{2}\left(\mathrm{Im} / \mathrm{m}^{2}\right) \\
\text { lux }(\mathrm{Ix}) \\
\text { lumen/Watts } \\
(\mathrm{Im} / \mathrm{W}) \\
\end{array}$ \\
\hline
\end{tabular}

A medição de irradiância é difícil de realizar porque o equipamento é dispendioso, não assim um luxo metro que é usado para medir iluminância e seu custo de adquirir-lo é menor. Por tais razões a medição de energia radiante se faz em termos de iluminância em lux ou "footcandle"; (1 lux =lumen $/ \mathrm{m}^{2}$; ou 1 
footcandle = lumen/foot $\left.{ }^{2}\right)$. A conversão de lux para "footcandle" é 1 footcandle = 10,764 lux. Para cada tipo de lâmpada a PHILIPS (1989) fornece o fator de conversão expresso em $\mathrm{mW} / \mathrm{lm}$, para converter o fluxo luminoso em fluxo radiante, portanto é possível obter a irradiância conhecendo-se a iluminância.

A medida de iluminância feita para resposta biológica é diferente que para a resposta da visão fotópica. Para um mesmo espectro, a sensibilidade de resposta é diferente, por exemplo: 300 lux emitidos por uma lâmpada incandescente não induz na mesma planta o efeito de 300 lux emitidos por uma lâmpada fluorescente, mas as duas lâmpadas apresentam a mesma estimulação visual, porque nas plantas, a maior sensibilidade de resposta ocorre fora dos comprimentos de luz visível, Figura 2.2.

DOWNS (1975) considera que, a fotometria do crescimento da planta se dá em termos de "radiação ativa fotossintética" (PAR), que é a relação da fotossíntese de uma "folha média", de forma similar às curvas de eficiência do espectro luminoso está na resposta de um "olho médio". A unidade da PAR é microeinstein $/ \mathrm{m}^{2} \cdot \mathrm{seg}$, esta medida pode obter-se somente na região do espectro de $400 \mathrm{~nm}$ até $700 \mathrm{~nm}$. Portanto a medida PAR não é possivel no efeito fotomorfogenético, que acontece na região de $700 \mathrm{~nm}$ até $800 \mathrm{~nm}$, onde há o maior efeito no crescimento e desenvolvimento da planta.

O crescimento da planta segundo IES (1993), pode ser medido também em quantum ou fluxo de fótons nos comprimentos de onda compreendidos entre 400 e $700 \mathrm{~nm}$ em micromoles/seg. $\mathrm{m}^{2}$ ( $\mu \mathrm{mol} / \mathrm{seg} \cdot \mathrm{m}^{2}$ por Watt/seg. $\mathrm{m}^{2}$ ) de luz do sol ou pela luz emitida por lâmpadas usadas para o crescimento das plantas. A conversão de fluxo de energia para fluxo de quantum vária com a distribuição espectral. A conversão de fluxo luminoso a fluxo de quantum ocorre entre 0,010 e $0,020 \mu \mathrm{mol} / \mathrm{seg} \cdot \mathrm{m}^{2}$ por lux. 


\subsubsection{APLICAÇÕES DAS FONTES DE LUZ ARTIFICIAL}

CANHAM (1966), diz que o número de horas de luz do dia (comprimento do dia), que uma localidade recebe nas diferentes épocas do ano depende da latitude, altitude e localização geográfica. Em regiões equatoriais, onde a latitude é zero, o comprimento do dia é aproximadamente 12 horas de luz e 12 horas de escuridão, mantendo-se praticamente os mesmos períodos de luz durante todo 0 ano, sem existir mudanças nas estações. Nas regiões dos hemisférios norte e sul - número de horas de luz natural diária depende da estação, no inverno pode alcançar de 8 até 10 horas e no verão até 16 horas.

Os objetivos para os quais se aplica a luz artificial no cultivo de flores, segundo IES (1993) são, principalmente para:

- Suplementação da luz do dia (fotossíntese)

- Modificação do tempo de luz do dia (fotoperiodismo)

- Substituição da luz do dia.

\section{Suplementação da luz do dia (fotossíntese)}

Se o período de luz do dia é curto, pode ser complementado usando luz artificial, antes do nascer do sol e depois do pôr do sol, obtendo-se como resultado desta aplicação: aceleração do crescimento vegetativo das plantas, (diminuição do tempo de propagação), aumento da colheita e melhoria da qualidade das plantas.

O nível e período de irradiação a serem aplicados depende: da espécie da planta, comprimento do dia e método do cultivo. Aplicar uma quantidade de luz artificial na forma de alta irradiância num curto tempo não tem o mesmo efeito que o baixo nível para longo tempo; CANHAM (1966) de acordo com experiências neste sentido recomenda a última aplicação como a mais apropriada. Além do 
tempo e nível de irradiância, não se deve descuidar dos outros fatores: como umidade, temperatura e nutrientes.

Para muitas espécies de plantas, diz DOWNS (1975) a quantidade de luz necessária para a fotossíntese está na ordem de 10 até 100 vezes mais que a quantidade requerida para fotoperíodo.

\section{Modificação do tempo de luz do dia (fotoperiodismo)}

O período adicional de luz artificial serve para: aumentar o crescimento vegetativo durante um intervalo de tempo mais longo, acelerar o crescimento vegetativo, adiantar ou retardar o momento de florescimento e melhorar a qualidade e a quantidade das flores.

Em certas plantas, como efeito de se prolongar a luz do dia, tornando os dias longos e noites curtas, a planta floresce. Em outras variedades se inibe a floração das plantas de dias curtos e noites longas. Em resumo: consegue-se o florescimento de plantas de dias longos e inibe-se o florescimento de plantas de dias curtos, PHILIPS (1983). O propósito de variar a época de florescimento é particularmente atrativo a fins comerciais.

A luz artificial usada exclusivamente para fotoperiodismo se aplica quando as necessidades do nível de irradiação é baixo na ordem de 0,5 até $1 \mathrm{~W} / \mathrm{m}^{2}$ e de pouco tempo da aplicação; para este fim é aceitável o uso de lâmpadas incandescentes ou lâmpadas compactas.

Uma das técnicas recomendadas por CANHAM (1966) para prolongar a luz do dia, é interrompendo os períodos de escuridão da noite, com fontes de luz artificial que opera em "ciclos de luz", os quais são curtos períodos de luz seguidos por curtos períodos de escuridão. A duração destes períodos está relacionada com a variedade e sensibilidade da planta. A luz fornecida durante 20 
até $30 \%$ do tempo permite que as plantas respondam como se a luz fosse fornecida de maneira contínua.

\section{Substituição da luz do dia.}

A técnica de substituir totalmente a luz natural pela luz artificial se aplica tanto em salas dedicadas para testes biólogos ou agrícolas, ou em cultivos feitos em quartos.

O cultivo em quartos é vantajoso e rentável quando as plantas têm as seguintes caraterísticas: -precisam de baixos níveis de irradiação; -precisam de alta temperatura; -o crescimento é rápido (de tal maneira que ocupam espaço durante pouco tempo); -são de pequeno porte, -alcançam bons preços fora da estação.

A substituição da luz natural, é usada para promover o crescimento rápido dos bulbos e para regular a germinação de sementes e mudas.

\subsubsection{TIPOS DE FONTES DE LUZ ARTIFICIAL UTILIZADAS NO CULTIVO DE FLORES}

Hoje a iluminação artificial é uma ferramenta importante para os floricultores. Permite-Ihes cultivar dentro de estufas, espécies e variedades de flores com ótimos resultados.

A luz artificial, de maneira similar à luz do sol, deve compreender todas as cores do espectro visível, já que a cor é fator determinante do tipo de crescimento da planta. Em geral a luz vermelha produz plantas com caule mais longo, enquanto que as cores azuis produzem o crescimento formativo, IES (1981). A falta da cor verde é caraterística das plantas que crescem em ausência de luz. 
Para alguns autores, como relata DOWNS (1966), a fotossíntese sob a luz vermelha é mais eficiente que sob a luz azul, acelerando a produção da clorofila; outros autores afirmam o contrário. Porém todos os comprimentos de onda entre $400 \mathrm{~nm}$ e $700 \mathrm{~nm}$ são ativos na síntese da clorofila, particularmente nas regiões azul e vermelha.

0 espectro efetivo para as plantas é na região do espectro azul de $350 \mathrm{~nm}$ até $450 \mathrm{~nm}$, e na região vermelha de $600 \mathrm{~nm}$ até $750 \mathrm{~nm}$, que podem estimular as foto-respostas das plantas (Figura 2.2).

Teoricamente as lâmpadas mais eficientes para fotossíntese podem ser as que emitem energia no comprimento de onda de $675 \mathrm{~nm}$, embora poderiam causar um excessivo elongamento do caule, afetando o crescimento formativo.

A eficiência das lâmpadas aplicadas na irradiação das plantas está determinada por dois fatores: - pela porção de energia elétrica convertida em energia radiante no espectro útil; - pela distribuição de energia radiante no espectro útil.

A escolha das lâmpadas depende de vários fatores: nível e tempo de irradiação, distribuição espectral que satisfaça as necessidades das diferentes espécies de plantas, suplementação, modificação ou substituição da luz do dia, ciclos de interrupção, espaço disponível e custos. A seleção da melhor lâmpada para uma aplicação específica pode ser difícil. Na prática comum se faz a escolha do tipo de lâmpada que há no mercado em função do custo.

De acordo com o manual da PHILPS (1989), usam-se como fonte de luz lâmpadas incandescentes de tungstênio e halogênio, e lâmpadas de descarga tais como: fluorescentes, mercúrio, compactas, metálicas e de sódio a alta pressão. Além disso várias combinações de lâmpadas são usadas. As combinações mais comuns são fluorescente e incandescente; alta pressão de 
sódio e halógena; alta pressão de sódio e mercúrio; alta pressão de sódio e incandescente.

\section{LÂMPADAS INCANDESCENTES}

\section{Lâmpada de tungstênio "GLS"}

As lâmpadas de filamento de tungstênio ou incandescentes, chamadas "General Ligthing Service" (GLS). São as mais simples, não precisam de nenhum controle especial e encontram-se facilmente no mercado, a baixo custo.

A lâmpada consiste de um filamento de tungstênio dentro de um tubo de vidro cheio de gás inerte ${ }^{2}$. Os extremos do filamento são conectados a contatos de metal que, por sua vez, fecham o tubo de vidro e constituem os contatos elétricos. A corrente elétrica que flui pelo filamento, aquece o mesmo, até uma temperatura tão alta que este emite radiação visual. A qualidade da luz depende da temperatura do filamento.

Tanto a duração como a eficiência (os lumens emitidos por watts consumidos) da lâmpada são determinados pela temperatura do filamento: quanto maior a temperatura maior eficiência e menor duração.

Segundo o manual de iluminação da PHILIPS (1983), as variações na tensão produzem mudanças na eficiência e vida da lâmpada. Para tensões de operação inferiores a $97 \%$ da tensão nominal, a vida útil não é alterada. Quando a tensão varia de $97 \%$ até $100 \%$ da tensão nominal, a vida da lâmpada mantémse em condições normais. A influência negativa na vida da lâmpada é devida ao aumento da tensão a níveis superiores ao nominal, para uma tensão $10 \%$ maior á nominal, a duração é de $28 \%$; como expressa a equação 2.1 :

\footnotetext{
2 Os gases inertes usados podem ser nitrogênio ou argônio ou os dois.
} 


$$
\begin{aligned}
& \text { Lo }=\text { vida sob tensão nominal (horas) } \\
& L=\text { vida sob tensão de ensaio (horas) } \\
& \text { Uo }=\text { Tensão nominal (volts) } \\
& \begin{array}{ll}
U= & \text { Tensão média efetiva durante ensaio (volts) } \\
n= & 13 \text { para lâmpadas a vácuo e } 14 \text { para lâmpadas a gás } \\
& \text { segundo norma NBR } 5387 / 1985
\end{array}
\end{aligned}
$$

Para tensões inferiores à nominal a eficiência é baixa e a vida aumenta, não assim para tensões maiores, portanto quando a eficiência da lâmpada aumenta e a vida útil diminui.

Uma lâmpada GLS de $100 \mathrm{~W}$ tem uma eficiência de $12,6 \mathrm{~lm} / \mathrm{W}$. A baixa eficiência é porque $75 \%$ da potência de entrada é irradiada no infravermelho, $19 \%$ perdem-se na forma de calor por condução e convecção, 0,25\% é irradiada no ultravioleta e somente $5,75 \%$ da energia é irradiada como luz visível. A emissão de radiação no infravermelho é aproveitada pelas plantas para fotossíntese.

As lâmpadas GLS são usadas para modificar o tempo de luz do dia (fotoperiodismo), já que emitem energia de baixa irradiância (200 até $800 \mathrm{~mW} / \mathrm{m}^{2}$ ), em espectro que facilita o controle do florescimento.

Geralmente as instalações com lâmpadas incandescentes operam em ciclos programados para se conseguir uma racionalização de energia, como expressa CANHAM (1966). Devido aos freqüentes acionamentos, a vida útil da lâmpada diminui.

Atualmente há lâmpadas especiais que têm em seu interior superfícies 
refletoras, como as lâmpadas "flower power" para aplicação no cultivo de flores. A superfície refletora permite direcionar a luz para baixo a fim de evitar as perdas de fluxo luminoso, emitido pela parte superior da lâmpada incandescente comum. Este tipo de lâmpada pode ser usada dentro de estufas ou ao ar livre, e é aplicado especialmente para fotoperiodismo. A principal vantagem das lâmpadas "flower power" é que economizam energia; uma lâmpada de $80 \mathrm{~W}$ equivale a uma de $100 \mathrm{~W}$ ou de $150 \mathrm{~W}$ sem superfície refletora. As caraterísticas nominais são apresentadas no Anexo A.

\section{- Lâmpadas halógenas}

São as lâmpadas de filamento de tungstênio dentro de uma atmosfera de vapor de elementos halogênios, como: iodo, cloro ou bromo para evitar que as partículas de tungstênio devido à alta temperatura se evaporem para depois condensar-se e enegrecer as paredes internas do tubo de vidro, reduzindo a emissão de fluxo luminoso. Apresentam maior eficiência, reduzem a porcentagem de deterioração do filamento

\section{LÂMPADAS DE DESCARGA}

A luz das lâmpadas de descarga não é produzida, como no caso das lâmpadas incandescentes, pelo aquecimento de um filamento, mas pelo arco de uma descarga elétrica mantida num gás ou vapor ionizado, algumas vezes em combinação com a luminescência dos compostos de fósforo excitados pela radiação gerada na descarga.

Como a energia elétrica é transformada diretamente em energia radiante, o processo é mais eficiente que nas lâmpadas em que intervém processos térmicos.

A emissão luminosa ocorre em bandas discretas chamadas "linhas", os 
comprimentos de onda que são caraterísticos do gás usado. A potência e intensidade das linhas dependem da pressão do gás. Os gases podem ser: mercúrio, sódio, neônio e xenônio. As caraterísticas elétricas da descarga do gás estão relacionadas com a tensão nominal.

As lâmpadas de descarga não podem funcionar sem um dispositivo, que limite a corrente que atravessa a lâmpada a um valor estabelecido, chamado reator, conectado em série com a lâmpada. 0 reator está constituído por bobinas ou combinação de bobinas e condensadores.

Para que comece a descarga usa-se um dispositivo de acendimento ou de ignição chamado "ignitor". Por si mesmo, ou junto com o reator, produz os impulsos de tensão que ionizam o caminho da descarga e facilitam a partida.

A ignição ocorre no período de partida, durante o qual o gás estabiliza-se podendo demorar até vários minutos dependendo do tipo de lâmpada. Neste intervalo o fluxo luminoso aumenta com um maior consumo de potência até que a lâmpada alcance seu valor nominal.

\section{- Lâmpadas fluorescentes (TL)}

São lâmpadas de descarga de vapor de mercúrio a baixa pressão. Além do mercúrio usa-se uma certa quantidade de gás inerte para facilitar o acendimento. A radiação emitida no espectro visível e ultravioleta é de baixa eficiência.

A lâmpada consiste de um tubo cilíndrico de vidro claro, com uma capa interna de pó fluorescente ou de fósforo (a quantidade destes compostos determina a cor da luz emitida). Nos extremos do tubo são colocados os eletrodos, que são bobinas de condutor recoberto com óxido metálico e estão presos ao casquete através do vidro que é fechado hermeticamente. Os extremos de cada bobina saem ao exterior do tubo e constituem os contatos elétricos. Ao 
iniciar a descarga os eletrodos são aquecidos e o material emissor favorece o fluxo de elétrons. A luz é gerada pelos pós fluorescentes ativados pela radiação ultravioleta da descarga.

As dimensões do tubo dependem da potência dissipada. A pressão de vapor e da densidade da corrente no tubo. A eficiência luminosa está relacionada com a potência dissipada por unidade de área do tubo e pelo tipo de fósforo usado, se a potência aumenta a eficiência também.

A eficiência de uma lâmpada fluorescente de $80 \mathrm{~W}$ : aproximadamente $2 \mathrm{~W}$ são dissipados como luz da própria descarga, $48 \mathrm{~W}$ como radiação ultravioleta, 12 W são convertidos em luz, 23 W são radiação de calor e 13 W são perdas por condução e convecção de calor. Portanto a emissão total de luz é 14 W (18\%), o resto de energia é dissipada em calor, $23 \mathrm{~W}(29 \%)$ em forma de radiação térmica e 43 W (53\%) como condução e convecção de calor. A distribuição espectral obtida depende da composição química e isotópica do pó fluorescente.

As lâmpadas fluorescentes são usadas em locais de altura limitada, onde o cultivo é feito em camadas. São instaladas muito próximas à planta. A distribuição luminosa é uniforme e tem a capacidade de iluminar uma grande superfície emitindo uma baixa quantidade de calor.

\section{- Lâmpadas compactas (SL*)}

São lâmpadas fluorescentes de mercúrio a baixa pressão de pequeno porte. Contêm em seu interior o reator em miniatura e o encaixe é do tipo universal (E-27) similar às incandescentes. Este tipo de lâmpada pode substituir as lâmpadas incandescentes para aplicações de fotoperiodismo, porque a eficiência máxima de radiação ocorre nos comprimentos de onda das cores azul verde e vermelho. 
Outra vantagem é a vida útil, que está em torno de 6.000 horas. Este tipo de lâmpadas é muito eficiente e permite uma substancial economia de energia, consumindo $25 \%$ de energia em comparação com as lâmpadas incandescentes de similar quantidade de luz.

\section{- Lâmpadas de sódio a alta pressão (SON-T)}

Outro metal comumente usado nas lâmpadas de descarga é o sódio. 0 tubo de descarga contém uma quantidade de vapor de sódio para proporcionar as condições de saturação quando a lâmpada está funcionando. Utiliza-se também mercúrio como gás amortecedor e inclui-se xenônio a baixa pressão para facilitar a partida e limitar a condução de calor do arco até as paredes do tubo. $\mathrm{O}$ tubo de descarga é de óxido de alumínio sintetizado, que resiste à intensa atividade química do vapor de sódio à temperatura de funcionamento, de $700^{\circ} \mathrm{C}$, e se deposita no interior de uma ampola protetora de vidro duro fabricado sob vácuo.

Nas lâmpadas a alta pressão, a luz emitida é descrita como "branco dourado". A maior emissão em linhas estreitas com alta intensidade é distribuída na faixa espectral que vai do verde ao amarelo, nos comprimentos de $570 \mathrm{~nm}$ até $630 \mathrm{~nm}$ e a emissão de energia diminui para o comprimento do vermelho.

Aproximadamente $85 \%$ da energia emitida é monocromática em $600 \mathrm{~nm}$. A eficiência luminosa é de $130 \mathrm{~lm} / \mathrm{W}$ e o nível de irradiância está entre 3.000 e $60.000 \mathrm{~mW} / \mathrm{m}^{2}$.

Na Figura. 2.4 pode-se visualizar a eficiência de uma lâmpada de $400 \mathrm{~W}$. A radiação visível é $118 \mathrm{~W}(30 \%)$, no infravermelho, $80 \mathrm{~W}(20 \%)$, as perdas nos eletrodos, $24 \mathrm{~W}$, as perdas não radiantes $176 \mathrm{~W}$, e $2 \mathrm{~W}$ de radiação no ultravioleta. Então o total de perdas é de 202 W (aproximadamente 50\%). 
Figura. 2.4 EFICIÊNCIA DE UMA LÂMPADA DE VAPOR DE SÓDIO A ALTA PRESSÃO.

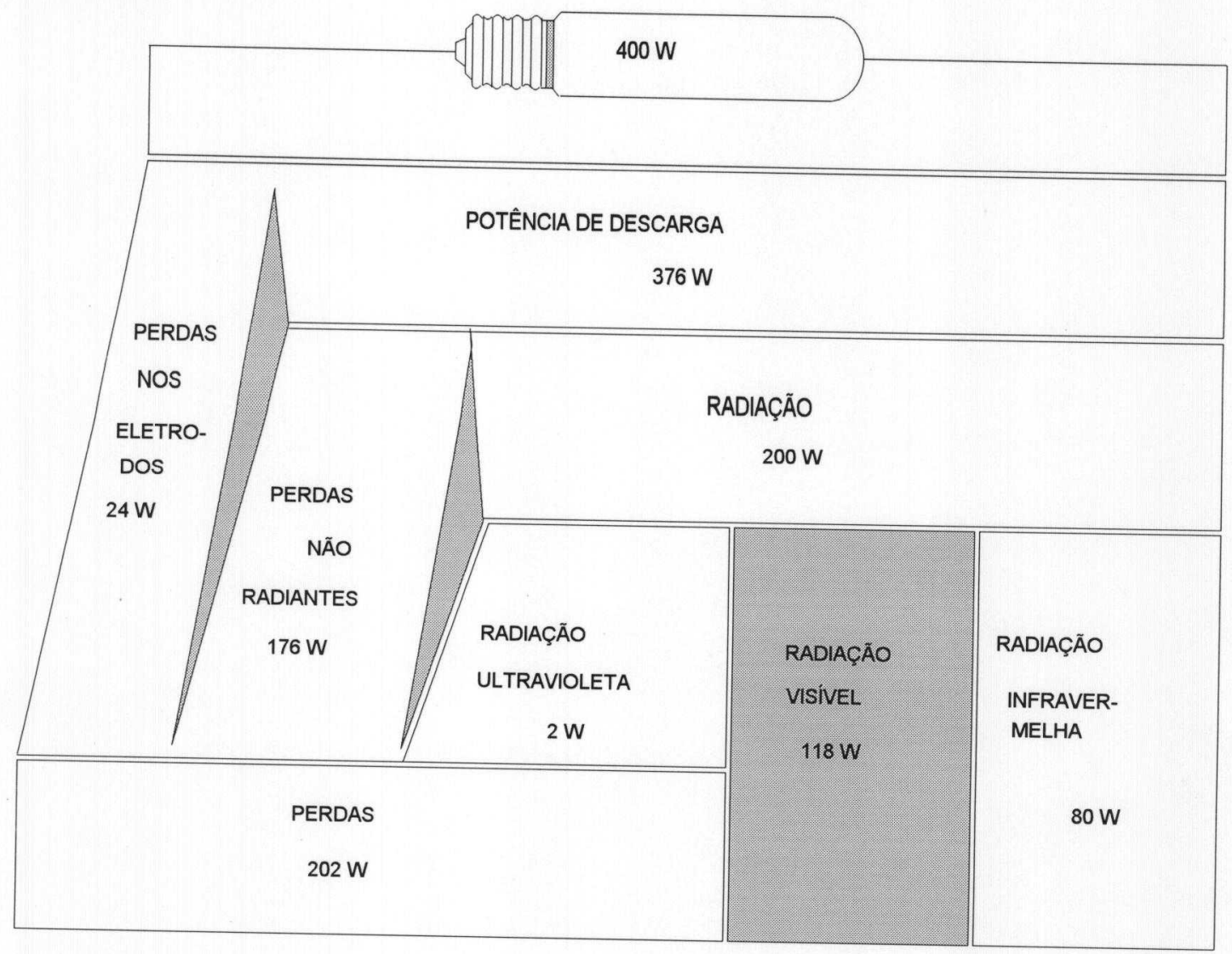

(Fonte: Manual da PHILIPS 1989)

A lâmpada de sódio a alta pressão têm longa vida. Numa lâmpada de 400 W, a perda de $50 \%$ de eficiência pode acontecer depois das 20.000 horas de uso. Os fatores que diminuem a vida da lâmpada são: as condições inadequadas do serviço, vibrações, partidas contínuas, perdas de sódio no tubo ou perdas nos eletrodos.

Em horticultura usam-se como suplemento da luz do dia (fotossíntese) as lâmpadas SON-T AGRO 400W (Philips), NAV-T 400W (Osram), Lucalux $400 \mathrm{~W}$ (GE), SONP-T $400 \mathrm{~W}$ (GEC). As lâmpadas SON-T AGRO 400W (Philips) são fabricadas com uma distribuição apropriada para as necessidades da planta para fotossíntese, fototropismo e fotoperiodismo, no Anexo A se apresenta as características deste tipo de lâmpadas, a distribuição espetral garante $30 \%$ de 
aumento no comprimento da cor azul, criando um equilíbrio entre a quantidade de "energia vermelha" e a "energia azul".

\section{-Combinação de lâmpadas}

As fontes de luz aplicadas para horticultura, de preferência, devem ter maior eficiência de energia radiante nos comprimentos de onda que sensibilizam as respostas das plantas como pode-se observar na Figura. 2.2. As lâmpadas antes mencionadas apresentam maior eficiência de energia radiante para certos comprimentos de onda. Nenhuma delas satisfaz todas as foto-respostas por si mesma. Por conseguinte é recomendável a combinação de alguns tipos de lâmpadas para compensar as deficiências de resposta que cada uma delas tem em determinado comprimento de onda.

As lâmpadas fluorescentes utilizadas para a fotossíntese tem melhor resultado com adição da energia proveniente de lâmpadas incandescentes, porque a radiação adicional das lâmpadas incandescentes ocorre no vermelho (de $600 \mathrm{~nm}$ até $700 \mathrm{~nm}$ ) e no infravermelho (de $700 \mathrm{~nm}$ até $800 \mathrm{~nm}$ ), onde as fluorescentes são deficientes. Não obstante, a planta necessita de energia nos comprimentos azuis das fluorescentes e vermelho das incandescentes.

As lâmpadas incandescentes e fluorescentes também são usadas em estufas para propósitos de fotoperiodismo. As lâmpadas incandescentes podem produzir maior elongação entrenó em alguns tipos de plantas.

É aconselhável usar lâmpadas a vapor de sódio a alta pressão que tenham radiação na cor azul, porque estas lâmpadas tem bom resultado na fotossíntese, e cor azul é necessária para o crescimento formativo da planta. 


\subsection{SISTEMAS DE IRRIGAÇÃO MÉTODO DE IRRIGAÇÃO POR GOTEJO}

O método de irrigação por gotejo foi desenvolvido em Israel, para irrigar plantas ornamentais cultivadas sob estufas. 0 maior interesse neste sistema foi porque ele permite maior economia de água aliado a um substancial aumento na produção das culturas, (CESP 1987). Atualmente a irrigação por gotejo tem-se desenvolvido bastante, devido principalmente ao aperfeiçoamento dos projetos e materiais.

\subsubsection{Aplicações}

A irrigação por gotejo exige um sofisticado sistema de filtragem da água e de fertilizantes e outros produtos químicos, tendo sido idealizado para condições específicas de uma agricultura altamente intensiva (LORDELLO 1987).

Os objetivos técnicos e agronômicos que motivam a escolha deste método de irrigação são:

- a possibilidade de obter alto conteúdo de umidade com baixo potencial de água no solo, sem problemas de aeração do solo.

- variações mínimas no conteúdo de umidade do solo durante o ciclo de irrigação.

- fornecimento de água para partes específicas do solo.

- a absorção de água pelo sistema radicular das plantas é mais eficiente.

- economizar água pela redução na evaporação, escorrimento superficial e percolação profunda (ALVES 1991).

- a pressão operacional do sistema deve ser relativamente baixa e com pequenos diâmetros para as tubulações. 
- requer um mínimo de mão de obra.

- 0 avanço tecnológico tem fornecido equipamentos adaptáveis às mais variadas situações e aos mais variados tipos de plantas.

\subsubsection{Componentes do sistema}

A irrigação por gotejo é baseada na pequena vazão através de orifícios de diâmetro reduzido, denominados gotejadores, inseridos em tubulações de plástico, localizadas sobre a superfície do solo. Os gotejadores tem a função de dissipar a pressão do sistema, para que a água possa ser aplicada em cada ponto, a uma vazão de somente alguns litros por hora (LORDELLO 1987). O sistema trabalha com uma pressão geralmente baixa, bem menor que a requerida pela aspersão. O sistema permite fornecer a água livre de impurezas e ainda com a possibilidade de aplicar substâncias químicas úteis para a planta.

Os componentes do sistema de irrigação por gotejo, são apresentados na Figura 2.5, e cumprem as seguintes funções:

Cabeçal de controle; compreendendo o conjunto moto-bomba, sistema de filtros (de areia e/ou de tela metálica), sistema injetor de fertilizantes e outros produtos químicos, sistema regulador da pressão e da vazão e sistema de controle automático de operação.

Geralmente está situado próximo ao abastecimento de água. O suprimento será por captação direta nos rios, ou reservatórios de acumulação (LORDELLO 1982).

O conjunto moto-bomba normalmente é considerado fora dos componentes do cabeçal, devendo fornecer a vazão e pressão desejadas. Em algumas ocasiões, o cabeçal de controle propriamente dito poderá estar localizado na parte mais alta do campo, bastante afastado do suprimento de água para evitar 
uma perda desnecessária de energia nas linhas de irrigação. Sua localização deve ser estudada através da forma, condições topográficas, modo de distribuição das tubulações, etc, podendo, ser subdividido em unidades secundárias para melhor manejo na irrigação.

Figura 2.5 COMPONENTES DO SISTEMA DE IRRIGAÇÃO POR GOTEJO

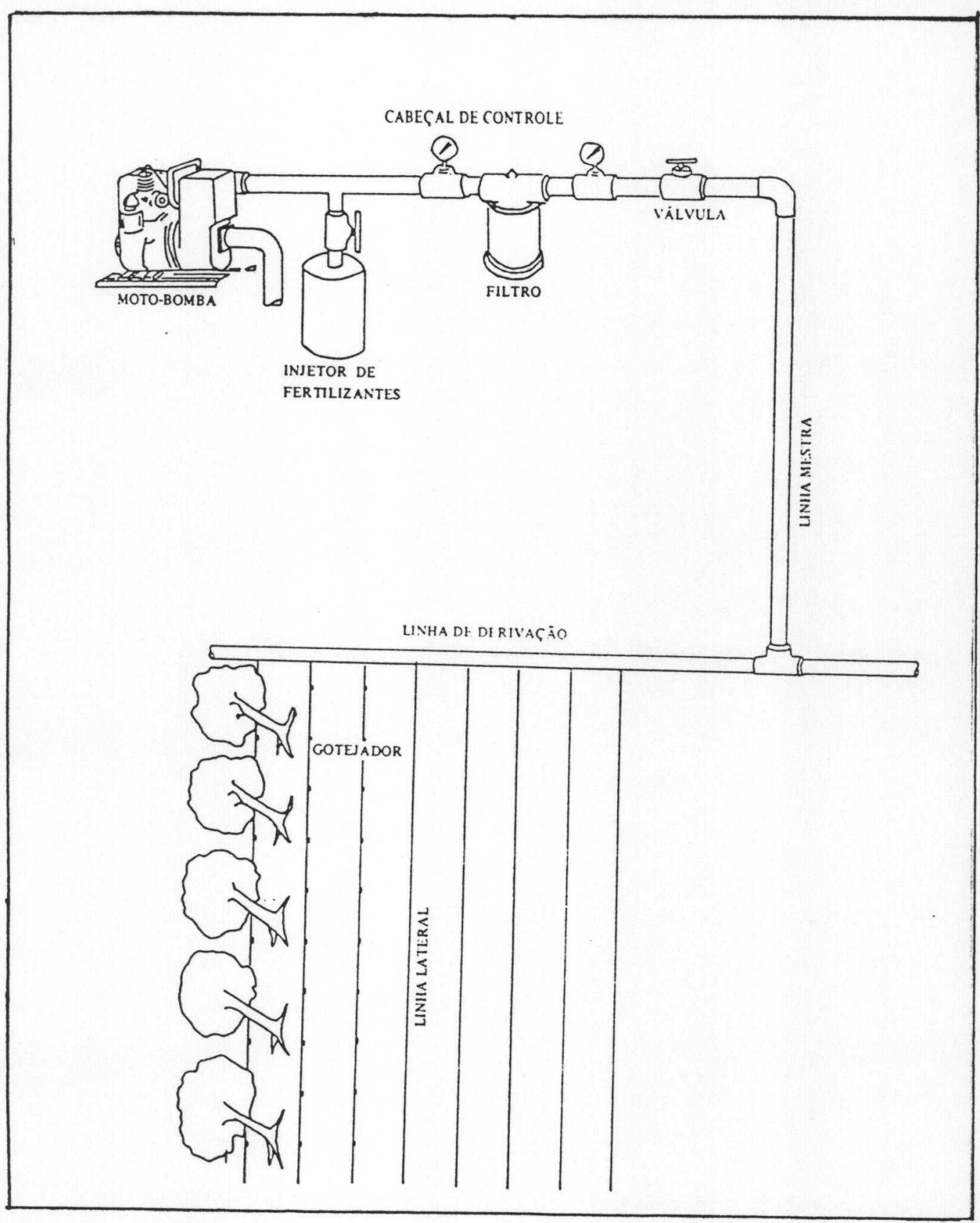

Fonte: LORDELLO Os métodos de irrigação, 1982 
A seqüência na posição dos componentes do cabeçal de controle pode variar de acordo com as necessidades e particularidades de um determinado projeto, mas de um modo geral, está na seguinte ordem: conjunto moto-bomba, válvula de controle (podendo ser um registro de controle manual ou uma válvula automática), válvula de retenção, saída para o tanque de fertilizantes, válvula redutora da pressão, entrada de fertilizantes, sistema de filtros de areia e/ou filtro de tela metálica, manômetro e saída para a linha mestre.

A válvula é utilizada para automatizar em certo aspecto, o funcionamento do sistema do gotejo. Ela permite uma regulagem de modo a se fechar automaticamente com a passagem de uma determinada quantidade de água.

A injeção de fertilizantes através de bombeamento permite um controle mais exato nas quantidades aplicadas, podendo-se conseguir uma alimentação continua em pequenas dosagens (LORDELLO 1982).

Sistema de filtragem. Os fatores que devem considerar-se na escolha de um sistema de filtragem são: a vazão, a pressão de funcionamento, perda de carga e a necessidade de limpeza (CESP 1987).

Os filtros comumente utilizados na irrigação por gotejo podem ser de areia ou de tela metálica. Outros tipos também são empregados como o de decantação ou de ação centrífuga.

O estudo de um sistema de filtragem pode levar à escolha da combinação de vários tipos no mesmo sistema, pois os filtros de areia retêm partículas finas e principalmente material orgânico, que normalmente obstruí as telas metálicas que são mais eficientes nas partículas finas.

Os filtros de areia apresentam camadas de cascalho e areia em diversos tamanhos e diversas espessuras de camadas, colocadas em recipientes 
cilíndricos. A água é introduzida na parte superior, passando através das camadas, deixando atrás as impurezas. Normalmente apresentam um sistema para a reversão do fluxo quando se faz a limpeza do filtro.

A operação de limpeza do filtro de preferência será praticada de maneira periódica, devendo-se evitar os tipos de filtros que exigem uma limpeza muito freqüente.

Os filtros de tela metálica são bastante simples e proporcionam um eficiente método de filtragem. $O$ tamanho dos orifícios e a área total do elemento filtrante determina a eficiência e os limites operacionais do sistema. Apresentamse geralmente em uma forma cilíndrica, constituindo-se de um recipiente metálico que pode apresentar malha de 0,074 mm. É comum a utilização de uma série de filtros ligados entre si para proporcionar a vazão desejada.

A necessidade de limpeza nos filtros pode ser determinada pela variação da pressão. Ao se projetar o sistema de irrigação, deve-se levar em consideração a perda de carga no filtro. É comum a utilização de conjuntos de filtros de areia e tela metálica, trabalhando em série para a filtragem da água na área total, em vez de pequenos conjuntos para áreas unitárias.

Tubulações: O princípio básico do método de gotejo prevê uma frequência de irrigação bastante alta, com aplicações de pequenas quantidades de água, com certo grau de pureza, permitindo ainda a introdução de substâncias químicas no sistema. Isto levou à utilização de materiais plásticos para as tubulações e acessórios de polietileno ou de PVC flexível, formando o reticulado necessário para abranger toda a área, que pode ser dividida em três categorias segundo sua finalidade: linha mestre, linha de derivação e linhas laterais (nestas últimas vão inseridos os gotejadores). Utiliza-se um extenso reticulado e tubulações em vários 
diâmetros para distribuir a água sob pressão, ao pé de cada planta.

A linha mestre faz a união do cabeçal do controle com as linhas de derivação utilizando-se tubulações de PVC ou polietileno, estando ou não enterradas para facilitar o trabalho da maquinaria agrícola.

A linha de derivação faz a distribuição da água para as linhas laterais, que podem estar ligadas à linha de derivação em um ou nos dois lados. O material utilizado é de polietileno flexível quando na superfície do solo ou PVC rígido que deverá estar enterrado. O dimensionamento é semelhante ao das linhas laterais, somente devido aos espaçamentos das saídas de água serem maiores e também maiores as vazões envolvidas. Nos terrenos, as linhas de derivação são colocadas no sentido da inclinação e as linhas laterais em nível, seguindo o contorno do terreno.

As linhas laterais realizam a distribuição da água para as plantas, através dos gotejadores que podem estar conectados de diversas maneiras.

Gotejador. É a estrutura mecânica idealizada para dissipar a pressão da água nas tubulações laterais, é a peça principal deste método de irrigação.

A vazão dos gotejadores pode variar desde 0,5 até 10 litros por hora (CESP 1987). A variação da pressão está determinada pelas perdas de energia por atritos, pela carga proveniente do atrito nas tubulações ou pelas diferenças de elevação de terreno (BARRAGAN 1993).

Como o orifício de fluxo do gotejador é reduzido, variado de 0,3 a 1,0 mm, sua confecção deverá ser exata e bastante uniforme na vazão. Quando o orifício de saída é muito pequeno, ele pode entupir facilmente. Aumentando a secção transversal do orifício, ocorre uma menor perda de energia e aumenta a vazão. Para se obter uma pequena vazão através de um grande orifício, é necessário 
reduzir a pressão da água entre a entrada e a saída no gotejador ou utilizando variados tipos de gotejadores.

O entupimento dos gotejadores é o problema mais comum, causado principalmente pela presença da partículas minerais ou orgânicas na água de irrigação, acarretando uma acentuada desuniformidade na distribuição ao longo das linhas laterais. A melhor defesa contra isto é proporcionar um bom sistema de filtragem pois é bastante trabalhosa a detecção e limpeza de gotejadores entupidos.

\subsubsection{Princípios básicos do método}

A irrigação por gotejo tem por base o conceito de que se logra um melhor uso da água e melhor desempenho agronômico da planta, já que evita-se déficit de água e mantém-se sempre condições favoráveis de umidade (LORDELLO 1987).

$\mathrm{Na}$ irrigação por gotejo, devido à alta frequência de operação, pode-se considerar o solo como um "reservatório de água" para as plantas, pois a frequência bastante alta supre as necessidades imediatas da planta.

A pequena vazão saindo do gotejador diretamente à superfície do solo, tem somente uma pequena área por onde se processa a infiltração. O efeito de qualquer método de infiltração da água no solo depende primeiramente das condições que prevalecem entre o solo e a superfície. No caso da irrigação por gotejo, estas condições podem ser definidas pela vazão do gotejador (q) medida como a quantidade de água por unidade de tempo e pela área (A) em que a infiltração se realiza. Foi observado que, em geral, esta área localizada pelo gotejador, apresenta em condições de saturação, formando um pequeno espelho de água na superfície. Como a presença da lâmina de água é muito pequena, o 
armazenamento superficial pode ser desprezado, indicando que a água proveniente do gotejador se infiltrará instantaneamente no solo. Deste modo, a taxa com que a água entra no solo através desta área, é equivalente à vazão do gotejador menos a evaporação (ALVES 1991). Isto é importante para o estabelecimento das condições do potencial da água no solo dentro do volume molhado pela irrigação.

Estes dados mostram que a vazão do gotejador tem um efeito marcante na forma do volume molhado. O aumento da vazão significa um aumento no sentido horizontal e um decréscimo na profundidade do volume molhado.

\subsubsection{Caraterísticas hidráulicas do sistema}

A irrigação por gotejo é baseada na vazão relativamente baixa dos gotejadores. Esta pequena vazão é conseguida pelo uso de pequenos orifícios na saída e uma pressão relativamente baixa no sistema.

O regime de fluxo no gotejador é caraterizado pelo número de Reynolds (NR), definido como a relação entre velocidade do fluxo no gotejador (V) em $\mathrm{m} / \mathrm{seg}$ e o diâmetro da secção transversal (D) em $\mathrm{m}$, pela viscosidade $(\rho)$ da água em $\mathrm{m}^{2} / \mathrm{seg}$, ou seja:

$$
\mathrm{NR}=\mathrm{V} \times \mathrm{D} / \rho \quad \text { Equação } 2.1
$$

Os regimes de fluxo podem ser definidos pelo valor de NR do seguinte modo: $\quad$ - regime laminar, $\quad \mathrm{NR}<2.000$

- regime crítico, $\quad 2.000<\mathrm{NR}<4.000$

- regime turbulento, NR $>4.000$

O tipo de regime está relacionado com a vazão dos gotejadores e diâmetro da secção transversal. 
No dimensionamento do sistema de irrigação o critério adotado é permitir uma variação máxima na vazão dos gotejadores de $10 \%$ em todo o campo(CESP 1987). A perda de carga permissível para produzir uma variação na vazão depende do tipo de gotejador e a relação entre pressão e vazão, ou seja, para produzir uma diferença de vazão de $10 \%$ nos gotejadores de regímen laminar a perda de carga máxima deve ser de $10 \%$ da pressão de serviço e nos gotejadores de regime turbulento a perda de carga pode atingir $20 \%$ da pressão de serviço. A diferença máxima na pressão devido a perda de carga ocorre entre as extremidades, isto é, entre o cabeçal na entrada do sistema e o último gotejador mais afastado. Estes dois extremos estão ligados à linha lateral e à linha de derivação, pois é comum a utilização de reguladores de pressão na entrada da linha mestre.

\subsubsection{Determinação do consumo de água}

O sistema de irrigação por gotejo envolve algumas considerações para assegurar uma aplicação correta da água, compatível com as necessidades da cultura.

A determinação da quantidade de água a ser aplicada é diferente às considerações dos métodos tradicionais, visto que somente parte do solo será molhado.

Para avaliar o consumo de água, tem-se desenvolvido muitos trabalhos que preconizam a utilização de dados de evaporação do tanque Classe $A$, (ALVES 1991). Este procedimento baseia-se no princípio de repor uma porcentagem da água perdida por evaporação, através da multiplicação por um fator (f) de consumo de água. Este fator recebe valores que variam desde 0,5 até maior que 1 , dependendo da cultura e das condições locais. 
A quantidade de água (V) a ser aplicada por pé por dia, pode ser calculada através da seguinte expressão:

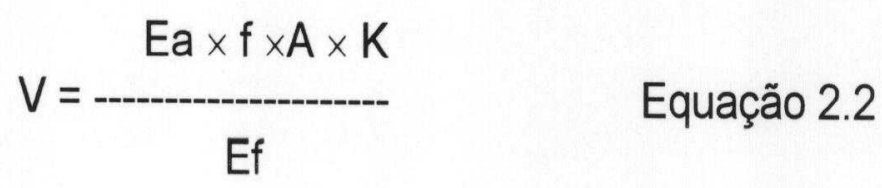

$$
\begin{aligned}
& V=\text { volume de água/pé/dia em litros; } \\
& \text { Ea = média de evaporação no tanque "Classe } \mathrm{A}^{\prime} \text { em } \mathrm{mm} / \mathrm{dia} \\
& \mathrm{f}=\text { fator de consumo de água } \\
& \mathrm{A}=\text { área correspondente ao espaçamento da cultura em } \mathrm{m}^{2} \\
& \mathrm{~K}= \\
& \quad \text { fator de cobertura relacionado com a porcentagem da área } \\
& \text { Ef = eficiência da irrigação }
\end{aligned}
$$

O volume $V$ de água será utilizado na determinação do tempo de irrigação, de acordo com a vazão e o número de gotejadores utilizados. Este cálculo também poderá ser feito com base na área total a irrigar.

Os valores de evaporação do tanque "Classe A" (CESP 1987) devem ser tomados no período mais quente do ano, considerando-se médias mensais e semanais. Na falta de maiores informações, recomenda-se utilizar o valor 0,60 ou 0,7 para o coeficiente $f$.

A área (A) é obtida simplesmente pela multiplicação do espaçamento entre linhas. No caso de culturas de espaçamento reduzido ou em linha, pode-se considerar a área de influência de um gotejador ou considerar a área total do projeto.

O fator de cobertura $(K)$ é calculado pela porcentagem de área coberta. Este fator assumirá o valor igual a 1 para culturas de espaçamento reduzido. 


\subsubsection{Eficiência do sistema de irrigação}

O rendimento da produtividade está diretamente relacionado com: a quantidade de água fornecida, o tempo que as plantas recebem a água e a eficiência de operação do sistema de irrigação (RODRIGUEZ 1993).

Uma otimização no consumo de água pode lograr-se quando, o manejo do sistema de irrigação é eficiente. Segundo expressa a equação 2.3 , a eficiência do sistema é a relação da quantidade de água consumida pela planta, com relação à quantidade de água fornecida.

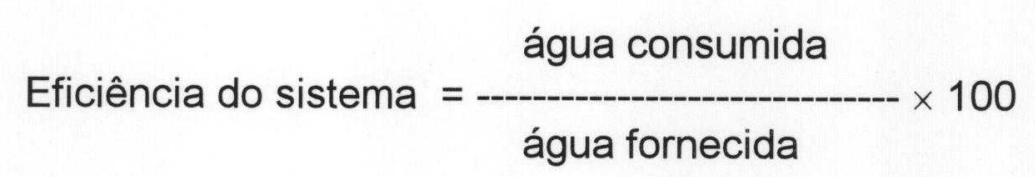

Equação 2.3

Os fatores que influem na eficiência do sistema são: a frequência ou doses de água fornecida ao cultivo, de acordo ao estudo realizado por RODRIGUEZ (1993), recomenda que a água fornecida deve molhar de 80 até $120 \%$ da profundidade radicular. Porém devido ao tipo de solos o requerimento de água é maior ou menor; no caso de solos argilosos há mais perda de água.

Outro fator que determina a eficiência do sistema de irrigação é a uniformidade de distribuição da água, portanto a pressão dos gotejadores deve manter-se constante e estar livre de entupimentos. Para o projeto deve considerar-se o gotejador que tem menor vazão como $\circ$ gotejador que determina o tempo de irrigação (IGLESIAS 1986).

Além dos fatores mencionados, para avaliar a eficiência devem levar-se em conta as perdas inevitáves da água por percolação profunda e por evaporação. 


\subsubsection{Benefícios e problemas na irrigação por gotejo}

Benefícios:

As perdas de água na irrigação são mínimas, proporcionam a maior eficiência dentro dos métodos de irrigação

Fornece de água diretamente à cultura

A resposta das plantas à irrigação por gotejo parece ser superior à dos outros métodos de irrigação. Muitos experimentos mostram melhor qualidade e uniformidade do produto.

Um sistema de irrigação manejado corretamente deverá proporcionar uma aeração eficiente ao solo, grande disponibilidade de nutrientes e um conteúdo de umidade útil para a planta.

Apresenta a possibilidade de automatizar o sistema

A irrigação não interfere com os tratos culturais.

Dificuldades do sistema de irrigação por gotejo:

Este método de irrigação está sujeito a entupimento dos gotejadores e o aumento da salinidade do solo (CESP 1987).

A obstrução do pequeno orifício de saída do gotejador é o problema mais sério neste método; detectar e limpar os gotejadores entupidos é bastante complicado. As causas de entupimento devem-se a: suspensão de materiais orgânicos, à baixa velocidade da água, à proliferação de microrganismos que obstruem o gotejador, à presença de compostos químicos como por exemplo a precipitação de carbonato de cálcio.

Outra desvantagem que apresenta este sistema é seu alto investimento, deve ser utilizado somente em culturas de alto retorno econômico, (LORDELLO 1987). 


\subsection{CÂMARAS DE REFRIGERAÇÃO}

A conservação das flores é um processo muito importante, sendo um produto de exportação, precisa chegar a seu destino final nas melhores condições, para que possa competir em qualidade e em preço.

\subsubsection{Cuidados básicos das flores dentro da câmara.}

Quando as flores são separadas (cortadas) do caule principal, elas experimentam uma morte súbita, rapidamente se desencadeia uma série de processos metabólicos e físicos que aceleram a deterioração da flor, como: se incrementa a respiração, desidratação, esgotamento dos nutrientes, evolução e efeitos do etileno, aumento de micro organismos (bactérias e fungos), acima dos níveis normais.

A respiração de maneira similar aos outros efeitos colaterais depende da temperatura. Normalmente a temperatura da flor é igual à temperatura do ar do ambiente, por tal razão as flores devem ser cortadas nas primeiras horas da manhã aproveitando a baixa temperatura. Depois de ser colhidas passam a uma etapa de classificação (ou controle de qualidade), imediatamente são armazenadas na câmara de refrigeração.

O resfriamento rápido é importante para prolongar a vida da flor, reduz o metabolismo dos tecidos, diminui a respiração, a produção de etileno e a multiplicação de micro organismos (RUDNICKI 1991). A respiração, normalmente imperceptível nas flores, pode provocar um reaquecimento, quando elas não estão submetida ao resfriamento, causando estragos irreversíveis.

Nas indústrias de flores utiliza-se o resfriamento com ar forçado, o calor é retirado com a ajuda de ventiladores que distribuem o ar dentro da câmara. Os tratamentos a baixa temperatura permitem conservar as flores por dias e semanas 
sem perda de qualidade, de tal maneira que possam suportar o transporte.

Durante o armazenamento é preciso manter constante a temperatura, a umidade relativa, a circulação do ar frio, sendo também necessária uma limpeza do interior da câmara.

Uma vez resfriada a flor não deve voltar a ser aquecida, porque perde qualidade. A temperatura média recomendada para a conservação da maioria das espécie de flores segundo o manual da ASHRAE (1994), varia de 0,6 até 0A umidade relativa que deve apresentar a câmara está na ordem de 90 ou $95 \%$. Sob estas condições o tempo mínimo que as flores pode ser armazenadas é uma semana (ASHRAE 1994).

O tempo de resfriamento das flores varia com as variedades e quantidades. Não obstante encontrou-se por exemplo, que para uma mesma quantidade de flores de gipsófila e crisântemos a relação do tempo de refrigeração é de 3 minutos a 20 minutos respetivamente, (ASHRAE, 1994).

$O$ pre-resfriamento pode ser praticado em algumas circunstâncias, porém mudanças freqüentes de temperatura podem prejudicar a flor provocando umidade superficial por condensação da água, além disso torna muito caro o processo de conservação da flor (HEUSSLER 1991).

Para embrulhar as flores podem usar-se três métodos conhecidos como: a seco, úmido ou controle da pressão; este último método é muito caro para ser praticado a nível industrial é aplicado para conservação em pequena escala.

O método de armazenar a úmido é usado para curtos períodos de 2 até 5 dias para todas as espécies de flores (RUDNICKI 1991). As flores uma vez cortadas são colocadas em água com nutrientes com a finalidade de hidratá-las, posteriormente são classificadas e embrulhadas em caixas de papelão. As paredes laterais da caixa tem pequenas janelinhas que permanecem abertas para 
que o ar frio da câmara, tire o calor do interior da caixa; em 20 ou 30 minutos o conteúdo da caixa está à temperatura da câmara. Em algumas espécies de flores para conseguir uma melhor conservação é necessário agregar compostos químicos na etapa de hidratação.

O método de embrulho a seco é mais eficiente para conservar por longo tempo. As flores são colocadas no interior da caixa sem passar pela etapa de hidratação. Todo o processo de embrulhamento realiza-se no interior da câmara (RUDNICKI 1991).

\subsubsection{Características técnicas da instalação da câmara de refrigeração}

A instalação frigorifica comumente utilizada é de ciclo de refrigeração por compressão. O líquido saturado a alta pressão retira o calor do meio para vaporizar-se quando a pressão se reduz, a vaporização do fluído refrigerante se realiza no evaporador. Para que novamente o fluído passe ao estado de líquido saturado a alta pressão intervim o trabalho do compressor que comprime o fluído refrigerante até a pressão inicial. Para voltar ao estado de líquido saturado a alta pressão o fluido passa pelo condensador.

O fluído refrigerante é o gás Freon-22 (mono cloro flúor metano). Para atingir a carga térmica, se instalam dois compressores, os quais operam alternativamente.

O sistema de condensação utilizado neste tipo de câmaras frigorificas geralmente é a ar. Nas indústrias que otimizam as instalações da câmaras, o ar quente emitido desde o condensador pode ser aproveitado para aquecer ambientes fechados onde realizam-se outros processos que precisam de calor.

Em relação aos evaporadores instalados de Freon-22, são de tipo ar forçado, eles estão conformados por grupos de 3 ou 4 ventiladores de baixa 
capacidade, da ordem de 1/4 HP. Os ventiladores distribuem a circulação do ar frio dentro da câmara, o ar é confinado a regiões próximas ao forro, havendo difusão uniforme pelo efeito ejetor do ar frio no ambiente da câmara.

O funcionamento da instalação pode incluir um controle de operação dos compressores e evaporadores, desta maneira se otimiza a operação da câmara conforme a carga térmica. 0 controle permite o funcionamento alternado dos compressores e evaporadores quando a carga térmica é grande. No caso contrário dará a sinal para o funcionamento de uma única unidade de refrigeração. Para o isolamento térmico as paredes e piso são revestidos de chapas metálicas com núcleo de poliuretano. 


\section{CARACTERIZAÇÃO DA REGIÃO NORTE DA SERRA EQUATORIANA}

Equador tem uma vocação agrícola muito importante, a contribuição deste setor nos aspectos econômico e social deve ser aproveitada pelo Estado, em procura das soluções que ajudem a superar a difícil crise interna do país.

Faz muitos anos que os produtos tradicionais provenientes do Equador, tais como: cacau, banana, camarão são colocados nos mercados mundiais, competindo com produtos de ótima qualidade.

As etapas de recessão econômica, a acumulação da dívida, entre outros fatores levaram ao governo a propor novas políticas agropecúarias que possibilitem a agro exportação de produtos não tradicionais, permitindo uma diversificação na produção agro exportadora.

Ao abordar as atividades agrícolas é importante referir-se aos fatores metereológicos. Um bom produto agrícola depende do clima, das caraterísticas do solo, das condições ecológicas.

\subsection{CARACTERÍSTICAS CLIMÁTICAS DA REGIÃO EM ESTUDO}

O Equador está situado ao nordeste da América do Sul, na latitude $01^{\circ} 20^{\prime}$ $\mathrm{N}$ e $05^{\circ} \mathrm{S}$, e desde o Oceano Pacífico até a parte oriental da planície Amazónia, (BLANDIN 1977).

O território do Equador está dividido em três regiões naturais, claramente definidas pela topografia, clima, vegetação e povoação. Estas regiões são "Litoral", "Serra", e "Oriente".

A 600 milhas da costa equatoriana, em direção oeste encontram-se as "Ilhas Galápagos". 
O Litoral compreende amplas planícies que vão desde os limites com o Peru até os limites com a Colômbia. As altitudes do Litoral variam desde o nível do mar até os 1.200 metros.

A região da Serra é atravessada pela "Cordilheira dos Andes" que vai de norte a sul. A Cordilheira se divide em dois sistemas paralelos: Cordilheira Oriental e Ocidental, separadas por uma planície comprida que está dividida em vários vales por nodos transversais. Na Serra as altitudes variam de 1.200 até 6.000 metros acima do nível do mar.

No Oriente existem planícies ainda não exploradas. Suas condições naturais são semelhantes a todas as regiões tropicais do mundo.

Devido à posição geográfica, e à diversidade de alturas impostas pela Cordilheira dos Andes, o Equador apresenta uma grande variedade de climas e mudanças substanciais a curtas distâncias, (BLANDIN 1977).

A divisão política do Equador é por "Províncias". As três regiões naturais encontram-se divididas em Províncias, sendo um total 20, mais Galapagos que constitui uma Província só. Por sua vez as Províncias contém "Cantões", os quais estão divididos em paróquias urbanas e paróquias rurais.

O cultivo de espécies e variedades de flores de corte para exportação se realiza na região da serra, que apresenta as melhores condições agro ecológicas de solo, temperatura, pluviosidade, níveis de radiação solar, entre outras que permitem obter produtos de qualidade, que satisfaçam as exigências do mercado. Atualmente as agroindústrias de cultivo de flores têm se espalhado em vários cantões da serra.

O presente estudo está restrito para a região Norte do Equador que se caracteriza como um grande vale com uma altura média em torno de 2.000 metros acima do nível do mar, fechado entre duas redes montanhosas a 5.000 metros 
acima do nível do mar. Do ponto de vista geográfico, a região se encontra em posição totalmente equatorial.

As atividade de floricultura na região norte tem-se desenvolvido nos cantões Cayambe e Pedro Moncayo pertencente à Província de Pichincha e os cantões Otavalo, Cotacachi e Ibarra pertencentes à Província de Imbabura. Mais ao norte na Província do Carchi (que é a Província do extremo norte, ver Anexo B), não existem agroindústrias dedicadas ao cultivo de flores. Portanto, para propósitos do estudo são definidos como a região norte da serra equatoriana, os cinco cantões .

HEUSSLER (1991) afirma que as flores equatorianas têm a fama de ser as melhores por sua qualidade, caule comprido, botões grandes, intensas cores e longa vida no vaso. Flores com estas caraterísticas obtém-se nas regiões altas. A região preferida para o cultivo de flores no Equador encontra-se a $80 \mathrm{Km}$ de Quito (Capital do Equador), nos cantões Pedro Moncayo e Cayambe a altitudes de 2.800 até 2.900 metros acima o nível do mar. A região tem clima pouco úmido, apresenta alto nível de luminosidade ${ }^{1}$, a temperatura média vai de $15^{\circ} \mathrm{C}$ até $18^{\circ} \mathrm{C}$, baixando na noite.

De características climáticas similares aos cantões Cayambe e Pedro Moncayo, são os cantões Otavalo e Cotacachi a 2.600 metros acima o nível do mar, diferente de lbarra localizada a 2.200 metros acima o nível do mar que apresenta a temperatura média até $24^{\circ} \mathrm{C}$ e com um clima mais seco.

\footnotetext{
1 BORRERO (1991) diz que a luminosidade é um fator muito importante na produção de flores de exportação. Em regiões de escassa luminosidade e horários restritos de luz solar pode causar problemas de fototropismo nas plantas.
} 


\subsection{HISTÓRICO DA PRODUÇÃO DE FLORES}

No estudo realizado pelo Banco Mundial (MORROW 1989), acerca do subsetor de flores, Equador incursiona como agro exportador de flores aos Estados Unidos desde o ano 1978.

HEUSSLER (1991) afirma que as atividades de produção de flores no Equador começaram dez anos mais tarde em relação à Colômbia que tinha desenvolvido este tipo de agro indústria. A agro exportação de flores é a presença de novos produtos equatorianos no mercado mundial.

Segundo as cifras estatísticas do Banco Central do Equador e do Programa de Exportações Agrícolas não Tradicionais (PROEXANT), o valor F.O.B. das exportações de flores subiu de US\$525.700 em 1985 para US\$35.616.223 em 1993.

A área dedicada ao cultivo de flores, segundo os dados apresentados por HEUSSLER (1991), para o ano 1990 em todo o país foi de 286 hectares, com uma taxa de crescimento anual do 19\%. Projetando estes dados, até dezembro 1993, a área em todo o país teria alcançado 494 hectares.

A produção de flores se faz em pequenas propriedades, de poucos hectares de superfície. A economia de escala não é significativa, portanto o tamanho da agro indústria não é importante.

Para a região em estudo, a área destinada em cada cantão para o cultivo de flores é apresentada na Tabela 3.1

Tabela 3.1 ÁREA DE CULTIVO DE FLORES POR CANTÃO

\begin{tabular}{|l|c|}
\hline CANTÕES & ÁREA (hectares) \\
\hline Pedro Moncayo & 104.5 \\
Cayambe & 89.3 \\
Otavalo & 24.5 \\
Cotacachi & 7.5 \\
Ibarra & 11.0 \\
T O T A L & 236.3 \\
\hline
\end{tabular}

Fonte: Usos finais de energia nas agroindústrias de cultura de flores. Enquetes 
Os 236,3 hectares correspondem à área das agroindústrias nas quais se fez a pesquisa, de usos finais de energia. (No capítulo 5 apresenta-se a informação da pesquisa realizada). Comparando com as cifras a nível nacional (494 hectares), a superfície desta região representa o 50\% da área que em todo o país é destinada para esta atividade.

O número de agroindústrias na região norte nos últimos cinco anos tem um incremento considerável, de 8 em 1989 até 39 em 1993, com uma taxa de incremento anual de $37 \%$. A Tabela 3.2 mostra a evolução no número de agroindústrias pertencentes a cada cantão.

Tabela 3.2: NÚMERO DE AGROINDÚSTRIAS NA REGIÃO NORTE

\begin{tabular}{|l|ccccc|}
\hline CANTÕES & \multicolumn{5}{|c|}{ ANOS } \\
\cline { 2 - 6 } & 1989 & 1990 & 1991 & 1992 & 1993 \\
\hline Pedro Moncayo & 4 & 5 & 13 & 14 & 21 \\
Cayambe & 3 & 4 & 6 & 7 & 12 \\
Otavalo & & 3 & 3 & 4 & 4 \\
Cotacachi & & & & 1 & 1 \\
Ibarra & 1 & 1 & 1 & 1 & 1 \\
T O T A L & 8 & 13 & 23 & 27 & 39 \\
\hline
\end{tabular}

Fonte: EMELNORTE (1993); Cadastro de consumidores de energia

O maior crescimento no número de agroindústrias tem-se nos cantões Pedro Moncayo e Cayambe, enquanto que nos outros cantões o número de agroindústrias se mantém.

O desenvolvimento das agroindústrias de cultivo de flores na região é bastante recente, seu acelerado crescimento demonstra que a atividade desenvolve-se com otimismo e se prevê um incremento progressivo para os próximos anos.

O crescimento vertiginoso da flori*cultura, como menciona WATERS (1992) deve-se a uma série de fatores, tais como: - as melhorias tecnológicas que se refletem no aumento da produtividade; - ao aumento no número de produtores; - 
ao aumento das variedades de exportação, que começou com cravos, rosas atualmente chega a mais de 40 variedades; - à participação de grupos de investidores não agricultores que diversificam seus investimentos 2 ; - ao ingresso de importantes capitais estrangeiros; - às ótimas condições agro ecológicas; - à disponibilidade de mão de obra relativamente barata; - por estar próximos geograficamente aos mercados mundiais.

O estudo realizado pelo Banco Mundial (MORROW 1989), mostra que desde o ano 1986 os países de Europa, Asia e Estados Unidos incrementaram as importações de flores, provenientes dos países onde as condições climáticas favorecem o cultivo.

O mesmo estudo afirma que a demanda das flores tem uma tendência a incrementar-se nos próximos 10 anos: se o consumo pecapita aumenta e se os produtores colocarem no mercado flores de qualidade a preços baixos.

\subsection{ASPECTOS ASSOCIADOS COM A PRODUÇÃO DE FLORES}

O desenvolvimento das agroindústrias de cultivo de flores, engloba aspectos de caráter econômico, social, ambiental e do mercado.

\subsubsection{Possibilidades de mão de obra}

A produção e exportação de flores tem geram a possibilidade de emprego de mão de obra para os habitantes rurais que moram nas regiões de desenvolvimento das agroindústrias.

A Tabela 3.3 apresenta os dados da população de cada cantão nos quais tem-se desenvolvido a atividade agroindustrial de cultivo de flores.

\footnotetext{
2 O investimento para o cultivo de flores ultrapassa os US $\$ 200.000$ por hectare.
} 
Tabela 3.3: $\quad$ DADOS DE POPULAÇÃO DA REGIÃO NORTE

\begin{tabular}{|l|c|c|c|c|c|}
\hline POPULAÇÃ & OTAVALO & CAYAMBE & $\begin{array}{l}\text { PEDRO } \\
\text { MONCAYO }\end{array}$ & IBARRA & COTACACHI \\
\hline URBANA & 21.508 & 16.849 & 3.114 & 80.991 & 6.051 \\
RURAL & 34.238 & 30.089 & 12.604 & 38.502 & 27.199 \\
TOTAL & 56.286 & 46.938 & 15.718 & 119.493 & 33.250 \\
P.E.A (*) & 18.978 & 15.699 & 5.680 & 40.019 & 12.308 \\
\hline
\end{tabular}

Fonte: INEC (1990). V Censo de población y vivienda 1.990

(*) PEA População Economicamente Ativa

As diferentes etapas do processo produtivo, como são a semeadura, cuidados, colheita, classificação e transporte, realizam-se manualmente. Portanto as agroindústrias precisam contratar pessoal que realize esta atividades. A Tabela 3.4 apresenta o número de funcionários das agroindústrias pertencentes a cada cantão.

Tabela 3.4: MÃO DE OBRA EMPREGADA NA PRODUÇÃO DE FLORES NA REGIÃO NORTE DA SERRA EQUATORIANA

\begin{tabular}{|l|c|}
\hline \multicolumn{1}{|c|}{ CANTÕES } & $\begin{array}{c}\text { MÃO DE OBRA } \\
\text { (Número de funcionários) }\end{array}$ \\
\hline Pedro Moncayo & 1.784 \\
Cayambe & 1.392 \\
Otavalo & 427 \\
Cotacachi & 150 \\
Ibarra & 170 \\
\hline T O TA L & 3.923 \\
\hline
\end{tabular}

Fonte:Usos finais de energia nas agroindústrias de cultivo de flores

Se comparamos a mão de obra empregada em cada cantão com o número de população economicamente ativa (PEA), a relação é muito baixa para os contões da Província de Imbabura e, diferentemente para Cayambe e Pedro Moncayo onde a relação é de $8 \%$ e $31 \%$ respectivamente.

Nas agroindústrias trabalham habitantes provenientes das regiões urbanas e rurais do próprio cantão e de cantões vizinhos, além disso existem habitantes 
de cantões próximos onde não há este tipo de agroindústrias que também prestam seus serviços nas agroindústrias. Portanto é um erro estabelecer uma relação direta da PEA com o número de funcionários de cada cantão.

Uma relação mais adequada é comparar a área utilizada para o cultivo com o número de funcionários, com o propósito de encontrar um fator que relacione o número de funcionários por hectare de cultivo. Na Tabela 3.1 apresenta-se o número de hectares cultivados para a região, e na Tabela 3.4 tem-se a mão de obra empregada. Pode-se inferir que esta atividade industrial é uma fonte de trabalho para 16 pessoas em cada hectare cultivado.

THRUPP (1992) afirma que aproximadamente $75 \%$ de mão de obra empregada pelas agroindústrias é representada por mulheres. Elas participam em todas as etapas do ciclo produtivo, na semeadura, nos cuidados diários, no corte das flores, no controle de qualidade e a embalagem. A presença da mulher é importante no trabalho produtivo rural.

Sob a responsabilidade dos homens estão os trabalhos de: preparação do solo e camas, fumigação, irrigação e transporte.

\subsubsection{Impactos ambientais}

As flores, para que possam ser exportadas, devem cumprir com padrões de qualidade que são principalmente: aparência física (frescor da flor), e estar livres de pragas e insetos. $O$ produto para ingressar no mercado consumidor passa por um rigoroso controle sanitário.

A sanidade da flor e sua qualidade são os fatores que dão a possibilidade de obter bons preços do produto. 
Com o propósito de obter ótima qualidade na produção, aumento no rendimento da produção por hectare, o cultivo requer o uso intensivo de agroquímicos, entre eles: praguicidas, fungicidas, pesticidas e o uso de fertilizantes.

Nos cultivos de flores as plantas são semeadas muito próximas entre si, formando um cultivo denso. A presença de pragas e pestes, ocasiona ao cultivo um estrago considerável.

De estudos realizados no Equador, RODRIGUEZ (1992) diz que o problema da contaminação é grave. Nas estufas de cultivo de flores a aplicação de pesticidas para o controle de insetos, é realizado cada três dias, e com a mesma frequência se realiza a aplicação de fungicidas.

Os agroquímicos utilizados provocam gravísimos problemas na saúde humana e no meio ambiente. Os funcionários que fazem a aplicação dos agroquímicos não estão protegidos e muitos não sabem manejar os agroquímicos, desta forma existe o risco de contaminar o meio ambiente empobrecendo o solo e contaminando a água.

O uso dos agroquímicos deve ter um controle e ser realizado em níveis adequados, porque eles causam no ser humano que está em contacto, doenças a médio e longo prazo, incluindo problemas no sistema reprodutor (esterilidade, câncer, tumores) e alterações no sistema nervoso.

A má operação dos sistemas de irrigação, provoca deterioração do meio ambiente, na medida em que não existe controle no fornecimento de água, o excesso de água ocasiona o lavagem de nutrientes do solo, levando o nitrogênio, potássio, fosforo e outros minerais a contaminar os rios mais próximos. 


\subsubsection{Mercado de flores}

A produção de flores no Equador está destinada ao mercado no exterior, extremamente exigente em termos de padrão da flor. 0 mercado depende basicamente de três fatores, que são: a qualidade, os cuidados do transporte e os preços.

A qualidade: além dos controles fito-sanitários, que garantem as condições fito-sanitárias das flores, as caraterísticas físicas são as que motivam os consumidores na compra do produto. Sendo as caraterísticas físicas os tamanhos, formas cores e o próprio frescor. A escolha das cores e tamanhos depende do mercado, geralmente os americanos preferem rosas e crisântemos de cores intensos, de botões grandes e de folhas largas. No mercado europeu a preferência é por as flores de cores pastel e tamanhos pequenos. O mercado Japonês, apresenta um padrão diferente, sendo as variedades preferidas os crisântemos e orquídeas. Outras variedades vendidas no mercado mundial, mas em menor quantidade, são as variedades de gladiolas, gipsófila, astroemerias, gerbera, statice, tulipas, íris, lilies, entre outras.

A atividade de exportação de flores, exige muitos cuidados no momento do transporte. O produto, por ser altamente perecivel, deve cumprir um processo de conservação a baixas temperaturas. Aliás, o transporte deve ser eficiente, para assegurar uma entrega imediata nos mercados de consumo. A demora no transporte pode influir na qualidade do produto e inclusive provocar estragos ou perdas totais da mercadoria.

Para os compradores de flores, se bem a qualidade é um fator importante, mas não é determinante. O fator que faz que um comprador escolha uma determinada flor é o preço. O preço depende de duas variáveis, que são: o mercado e a estação do ano. Os países importadores situados no hemisfério 
norte, demanda a maior quantidade de flores no inverno (dezembro até fevereiro). Outras épocas pico de venda de flores são os dias de comemorações especiais, como dia das Mães, São Valentim (fevereiro). Para alcançar um maior benefício nestas épocas, os exportadores mantém um planejamento de produção, de tal maneira de colocar no mercado o maior volume de flores nos períodos de demanda máxima.

De acordo com o estudo realizado pelo Banco Mundial (1989), para os países em desenvolvimento, a produção de flores apresenta três vantagens: baixos custos de produção, ter as possibilidades de produzir em estações complementares às do hemisfério norte e as poucas regulações governamentais.

Baixos custos de produção.- Dos materiais utilizados, os fertilizantes podem ser considerados como um forte gasto, mais eles estão diretamente relacionados com a quantidade e qualidade da flor, portanto o custo é plenamente recuperado. A despesa com energia não é alta, já que não existe um gasto de energia para criar condições favoráveis de temperatura dentro das estufas de cultivo, como é necessário nos países de clima quente.

. Manter a produção fora das estações é uma grande vantagem, nos países nos quais $\mathrm{o}$ ano inteiro, existe alta luminosidade e não se alternam dias curtos e dias longos.

Poucas regulamentações governamentais. O preço final não está afetado como nos países onde existem regulamentos para o uso da terra, da água, uso dos pesticidas, fatores que influem no preço do produto final. 


\subsection{CONCLUSÕES}

- Neste capítulo foi apresentada uma visão geral das condições climáticas que apresenta a região. Estas condições são propícias para o cultivo de flores, obtendo-se um produto de ótima qualidade e em todas as épocas do ano.

- É importante conhecer as condições climáticas porque elas influem na utilização do equipamento elétrico, assim no caso das regiões quentes, demanda de um maior número de horas de uso dos sistemas de irrigação, porque as plantas apresentam uma maior evapotranpiração.

-Outros aspectos abordados neste capitulo foram: a mão de obra empregada, os impactos ambientais devido ao uso de agroquímicos e o mercado de flores. Para o cultivo de flores o emprego de mão de obra é relativamente baixo, de 16 pessoas por hectare. Porém para o cantão Pedro Moncayo o cultivo de flores é a única atividade industrial neste cantão, portanto abre as possibilidades de emprego para a população rural, deste cantão.

- A atividade de cultivo de flores merece um controle permanente por parte dos Ministérios de Agricultura e Saúde, já que o uso intensivo de agroquímicos compromete o meio ambiente e a saúde do pessoal que está em contato direto com estes agroquímicos.

- É recomendável fazer uma avaliação da conveniência de sublimar o enxofre com uma despesa de energia elétrica, evitando desta maneira o uso intensivo de agroquímicos. 
- Sendo as condições climáticas propícias para produzir flores em todo o ano, o produto pode ser entregado no mercado internacional na época de inverno do hemisfério norte, a qual coincide com o período de ponta (Natal e São Valentim) no uso de flores. De fato esta situação torna mais dinâmica à atividade de produção. 


\section{RELAÇÃO DO SETOR AGRO-INDUSTRIAL COM A CONCESSIONÁRIA DE ENERGIA}

\subsection{DEMANDA DE POTÊNCIA E CONSUMO DE ENERGIA}

\subsubsection{Perfil da concessionária}

A concessionária de energia elétrica que atende à região norte da serra equatoriana é a Empresa Eléctrica Regional Norte (EMELNORTE). A área de concessão abrange às Províncias de Carchi, Imbabura e uma parte da Província de Pichincha, os cantões Cayambe e Pedro Moncayo. O Anexo B, apresenta a área de concessão e o diagrama do sistema de subtransmissão da EMELNORTE.

A demanda de potência média mensal da concessionária no ano 1993 foi de $45 \mathrm{MW}$ e a demanda média mensal de energia no mesmo ano foi de 13.951 $M W h^{1}$. O fator de carga $(\mathrm{Fc})$ médio mensal é 0,51 .

Para atender a demanda de potência e energia a EMELNORTE contratou durante o ano 1993 à "Dirección de Operación do Sistema Nacional Interconectado" (DOSNI) ${ }^{2}$, a compra de $30 \mathrm{MW}$ de potência máxima mensal e energia média mensal de $12.040 \mathrm{MWh}$. O resto da potência e energia, para completar sua demanda foi obtida de seu próprio sistema de geração.

A EMELNORTE dispõe de $12.5 \mathrm{MW}$ de potência instalada em pequenas centrais hidráulicas e $2.5 \mathrm{MW}$ de uma central térmica a óleo diesel.

A operação do sistema de geração se faz, da seguinte maneira: durante as horas pico, das $18 \mathrm{~h}$ até as $22 \mathrm{~h}$, operam a plena carga os $15 \mathrm{MW}$ das pequenas centrais da EMELNORTE e compra-se $30 \mathrm{MW}$ do Sistema Nacional Interconectado (SNI). Fora das horas pico, a geração própria diminui a $10 \mathrm{MW}$ e o

\footnotetext{
1 Fonte EMELNORTE, Suministro de potencia y energía del Sistema Nacional Interconectado. Ibarra 1993 2 O Instituto Ecuatoriano de Electrificación INECEL, administra o sistema de geração e transmissão interconectado em todo o país, através da Dirección de Operación del Sistema Nacional Interconectado (DOSNI).
} 
resto da potência é completada com a compra do SNI.

0 número de consumidores servidos pela concessionária em dezembro 1993 foi de 89.346, em todos os setores de consumo3. A Tabela 4.1 e Figura 4.1, apresentam a participação de cada setor, tanto no número de consumidores, quanto na energia consumida por setor no ano 1993.

Tabela 4.1: C CONSUMO POR TIPO DE SERVIÇO NO ANO 1993

\begin{tabular}{|c|c|c|c|c|c|c|}
\hline \multirow[t]{2}{*}{$\begin{array}{l}\text { SETOR DE } \\
\text { CONSUMO }\end{array}$} & \multicolumn{2}{|c|}{ CONSUMIDORES } & \multicolumn{3}{|c|}{ ENERGIA ANO } & $\begin{array}{l}\text { ENERGIA } \\
\text { MÊS }\end{array}$ \\
\hline & NÚMERO & $\begin{array}{l}\text { CENT } \\
(\%) \\
\end{array}$ & MWh & $\begin{array}{c}\text { PORCENT } \\
(\%) \\
\end{array}$ & $\begin{array}{c}\text { POR } \\
\text { CONSUMI } \\
\mathrm{kWh} \\
\end{array}$ & \begin{tabular}{|l|} 
POR \\
CONSUMI \\
$\mathrm{kWh}$
\end{tabular} \\
\hline Residencial & 79.279 & 88,73 & 75.708 & 45,22 & 955 & 80 \\
\hline Comércio-Serviços & 8.287 & 9,28 & 22.973 & 13,72 & 2.772 & 231 \\
\hline Iluminação Pública & 14 & 0,02 & 14.750 & 8,81 & 1.053 .571 & 87.798 \\
\hline Bombeio água & 47 & 0,05 & 4.824 & 2,88 & 102.638 & 8.553 \\
\hline Industrial & 1.209 & 1,35 & 48.114 & 28,74 & 39.797 & 3.316 \\
\hline Outros & 510 & 0,57 & 1.039 & 0,62 & 2.037 & 170 \\
\hline T O T A L & 89.346 & 100,00 & 167.408 & 100,00 & & \\
\hline
\end{tabular}

Fonte: EMELNORTE Estatísticas por tipo de serviço, Ibarra 1993

O setor de maior participação é o setor residencial, tanto no número de consumidores que corresponde a $88,7 \%$ do total, quanto no consumo de energia que é $45,2 \%$. É importante notar que o consumo por domicílio é muito baixo (Tabela 4.1), aproximadamente $80 \mathrm{kWh} / \mathrm{mês}$. Este índice de consumo reflete a baixa renda da região. O uso predominante no consumo residencial é a iluminação, sendo o responsável pelo alto pico de demanda nas primeiras horas da noite.

Seguindo uma ordem decrescente do consumo está o setor industrial, que tem um consumo significativo do $28,7 \%$, não obstante ter um baixo número de consumidores de apenas $1,3 \%$.

${ }^{3}$ Fonte: EMELNORTE Estadísticas de consumo. Ibarra 1993 
Figura 4.1:

\section{SETORES DE CONSUMO EMELNORTE \\ NO ANO 1993}

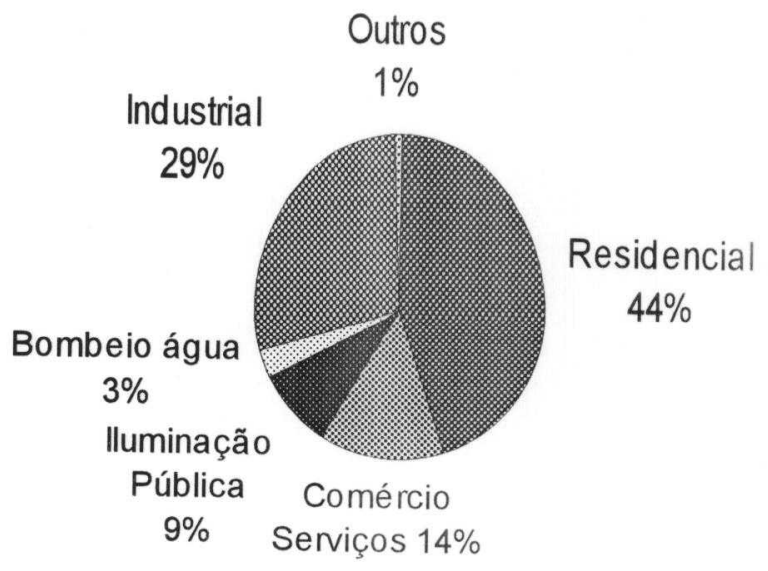

De menor participação no consumo é o setor comércio-serviços, que representa $13,7 \%$ e o número de consumidores é $9,3 \%$.

Os 14 consumidores do setor de iluminação pública correspondem às 14 Agências que a concessionária tem espalhadas em toda sua área de concessão, já que se registra a informação de iluminação pública por Agência. O consumo deste setor está na ordem de $9 \%$ do consumo total da EMELNORTE.

A participação do setor de bombeio de água e dos outros setores é pequena.

\subsubsection{Participação do setor agroindustrial de cultivo de flores no consumo de energia e na demanda de potência da EMELNORTE}

A participação do setor industrial no consumo global da EMELNORTE representa $28,7 \%$. Por sua vez o setor industrial encontra-se desagregado nos subsetores: cimento, têxteis, laticínios, flores e outros. 
Dentro do setor industrial, o sub-setor de flores representa $22,4 \%$ do consumo de energia 4 . A Tabela 4.2 e a Figura 4.2 apresentam a participação dos sub-setores industriais dentro de todo o setor industrial. Apesar do significativo consumo do sub-setor de flores no setor industrial, o consumo das agroindústrias dentro do total da EMELNORTE, não ultrapassa 6,4\%.

Tabela 4.2: CONSUMOS PARCIAIS DO SETOR INDUSTRIAL NO ANO 1993

\begin{tabular}{|l|rr|cr|}
\hline \multirow{2}{*}{$\begin{array}{l}\text { SUB-SETOR CONSUMO } \\
\text { DE CONSUMIDORES }\end{array}$} & \multicolumn{2}{|c|}{ ENERGIA } \\
\cline { 2 - 5 } & $\begin{array}{c}|c| \\
\text { NÚMERO }\end{array}$ & $\begin{array}{c}\text { PORCENTAGEM } \\
\text { (\%) }\end{array}$ & MWh & $\begin{array}{c}\text { PORCENTAGEM } \\
(\%)\end{array}$ \\
\hline Cimento & 1 & 0,08 & 20.537 & 42,68 \\
Têxteis & 15 & 1,24 & 3.591 & 7,46 \\
Laticínios & 12 & 0,99 & 5.110 & 10,62 \\
Flores & 55 & 4,55 & 10.778 & 22,40 \\
Outros & 1.126 & 93,13 & 8.097 & 16,83 \\
T O T A L & 1.209 & 100,00 & 48.114 & 100,00 \\
\hline
\end{tabular}

Fonte: EMELNORTE. Estatísticas por tipo de servicio, Ibarra 1993

Figura 4.2

\section{SETOR INDUSTRIAL EMELNORTE \\ NO ANO 1993}

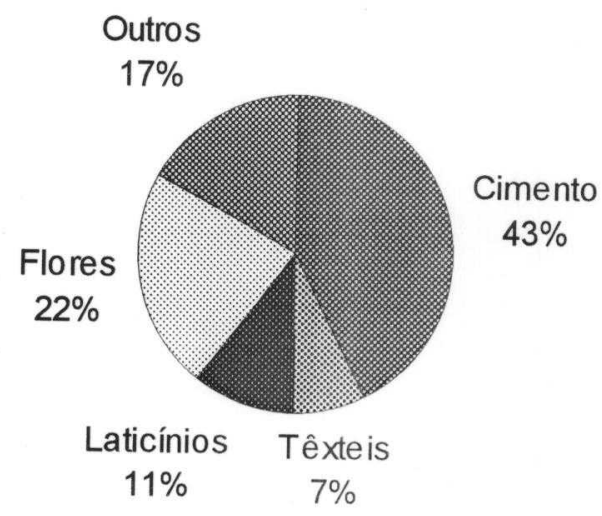

${ }^{4}$ Fonte: EMELNORTE Estadísticas de consumo 1993 
O número de agroindústrias na região norte é 39 em dezembro 1993, como se apresenta no capítulo 3. Aliás na Tabela 4.2 constam 55 consumidores do subsetor de flores. Esta diferença deve-se a 0 fato de que muitas agroindústrias possuem mais de um medidor. A infra estrutura interna das agroindústrias é implementada progressivamente a curto prazo. A expansão das instalações requer novos transformadores e no secundário de cada um deles instala-se 0 medidor. (Na seção 4.2 deste capítulo explica-se melhor o porque desta diferença)

O cultivo de flores é bastante recente na região, o desenvolvimento destas agroindústrias apresentam uma demanda crescente de potência e energia. Nos últimos cinco anos (1989-1993), o consumo de energia experimentou um crescimento de 0,18 MWh de consumo máximo mensal em 1989, até 1,18 MWh de consumo máximo mensal no ano 1993. Na Figura 4.3, encontram-se as curvas do consumo mensal dos cinco últimos anos. A taxa anual de incremento do consumo de energia é $63 \%$.

A potência contratada pelas agroindústrias de flores passou de 0,75 MW em 1989 até 4,4 MW em 1993, valor que hoje representa 10\% da demanda da concessionária. (Ver Figura 4.4).

A participação do setor agroindustrial na demanda de potência é de $10 \%$, e no consumo de energia em torno de $6.4 \%$. Com respeito ao global da EMELNORTE, aparentemente as cifras são baixas, mas o setor agroindustrial encontra-se em constante crescimento, tanto no número de agroindústrias a uma taxa anual de $37 \%$, quanto na demanda de potência e energia. Portanto é importante que a concessionária cuide deste mercado que poderia transformar-se numa importante receita. 


\section{Figura 4.3}

CONSUMOS DE ENERGIA (1989 - 1993)

PARA O CULTIVO DE FLORES

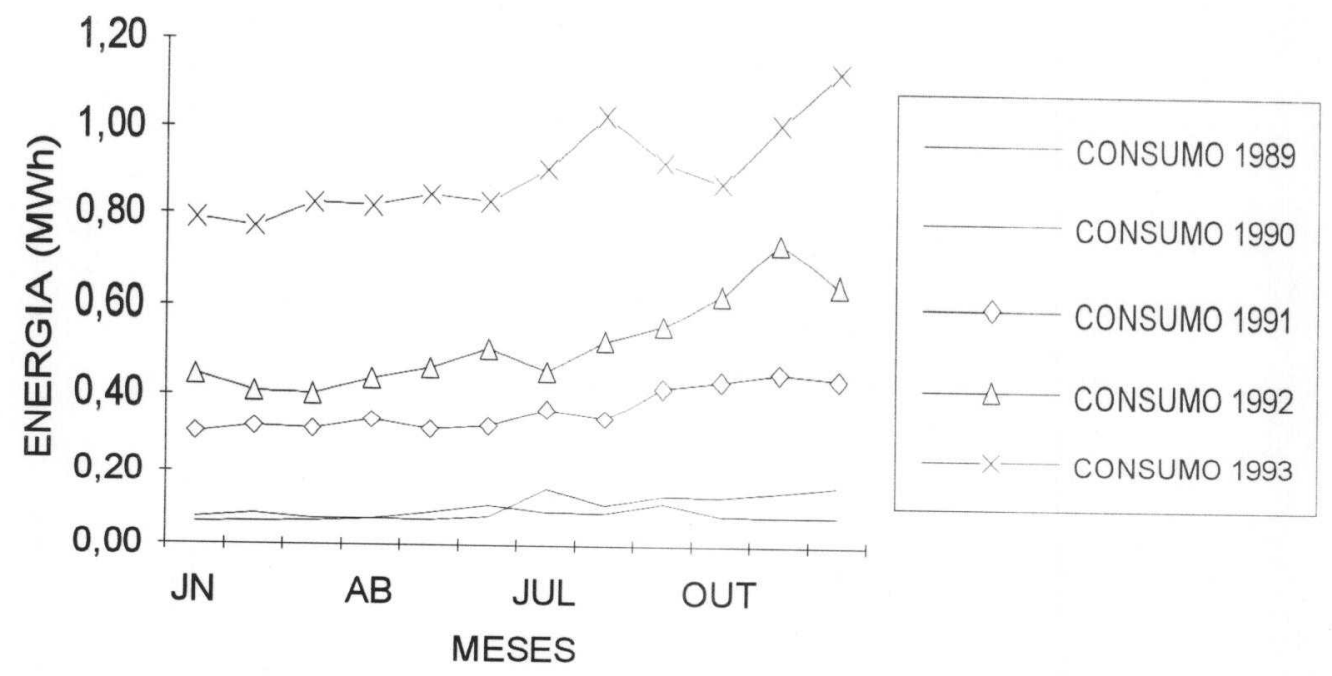

Figura 4.4

DEMANDA DE POTÊNCIA (1989 - 1993)

PARA O CULTIVO DE FLORES

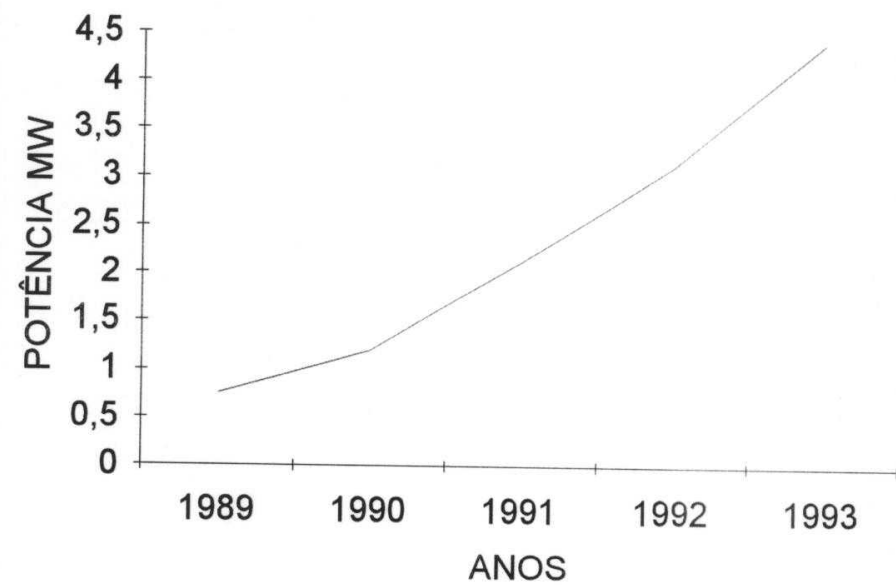

A efervescência na formação de novas agroindústrias e a execução dos programas de expansão, das agroindústrias localizadas nos cantões Cayambe e Pedro Moncayo, ocasionaram nos anos 1992 e 1993 sobrecarga do transformador 
da subestação Cayambe e nos alimentadores primários. Esta situação motivou à concessionária a limitar o serviço, dificultando a expansão e formação de novas agroindústrias, pela falta de disponibilidade de potência.

A manter-se o ritmo de crescimento, as agroindústrias demandarão do sistema EMELNORTE, nos próximos três anos uma potência de 12,6 MW e o consumo máximo mensal das agroindústrias possivelmente chegará a 7,8 MWh.

\subsubsection{Comportamento do consumo agroindustrial na curva de carga Comportamento do consumo agroindustrial na curva de carga do circuito Pedro Moncayo}

A Tabela 3.2 apresenta o número de agroindústrias pertencentes a cada cantão.

A maior concentração de agroindústrias tem-se no cantão Pedro Moncayo, praticamente a metade do número total das agroindústrias.

Para atender o serviço elétrico do cantão Pedro Moncayo, a EMELNORTE dispõe de um alimentador primário que sai desde a subestação Cayambe. A Figura 4.5 apresenta a curva de carga do alimentador primário (para um dia típico), na qual foram incluídas as curvas de carga de cada uso final, das 17 agroindústrias pesquisadas neste cantão.

Analisando os usos finais das agroindústrias, o mais representativo é a iluminação, o pico de potência máxima alcança $423 \mathrm{~kW}$ e ocorre às $20 \mathrm{~h}$, de fato a iluminação utilizada no cultivo e na sala de abertura das flores é ligada desde as $18 \mathrm{~h}$ até $4 \mathrm{~h}$ diariamente.

Os sublimadores apresentam uma potência máxima de $293 \mathrm{~kW}$ das $20 \mathrm{~h}$ até as $22 \mathrm{~h}$, fora destas horas a curva desce, permanecendo constante das 18h até as $5 \mathrm{~h}$. A ligação destes aparelhos é diária. 
Os sistemas de irrigação: operam em dois períodos, o primeiro período vai de $6 \mathrm{~h}$ até $11 \mathrm{~h}$ e o segundo período de $15 \mathrm{~h}$ até $18 \mathrm{~h}$, nestes períodos há dois picos de potência máxima de $352 \mathrm{~kW}$ ás $9 \mathrm{~h}$ e ás $16 \mathrm{~h}$.

\section{Figura 4.5}

\section{CURVA CIRCUITO PEDRO MONCAYO CURVAS DE CARGA POR USO FINAL}

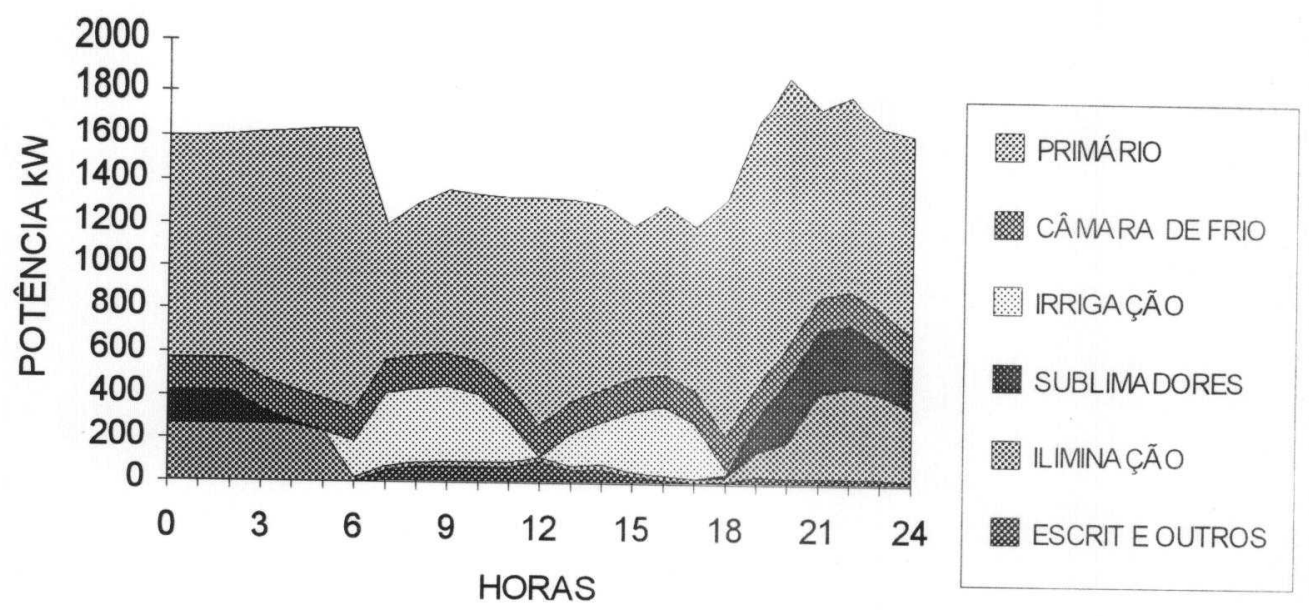

As câmaras de refrigeração apresentam uma potência constante de 149 kW durante as 24 horas do dia.

Outro uso analisado neste estudo é denominado escritórios e outros serviços gerais. A potência máxima deste uso é $99 \mathrm{~kW}$ ao meio dia, fora desta hora a potência diminui quase simetricamente, mantendo durante todo o dia uma potência de $20 \mathrm{~kW}$.

Somando a potência de cada uso final, em cada hora do dia obtem-se a envolveste de todos os usos ou o comportamento de consumo das 17 agroindústrias existentes neste cantão. O pico de potência máxima é 900 kW e ocorre às 22h. A potência deste setor agroindustrial representa a metade da potência máxima de todo o alimentador. 


\section{- Comportamento na curva de carga do sistema EMELNORTE}

O Figura 4.6 apresenta a curva de carga do sistema da EMELNORTE, a demanda mínima nas horas vale é de $12 \mathrm{MW}$, o pico de demanda máxima que vai das $18 \mathrm{~h}$ até às $22 \mathrm{~h}$ é de $45 \mathrm{MW}$ e ocorre às $19 \mathrm{~h}$. Conjuntamente com a curva de carga do sistema foram colocadas as curvas de carga de cada um dos usos finais das agroindústrias.

Figura 4.6:

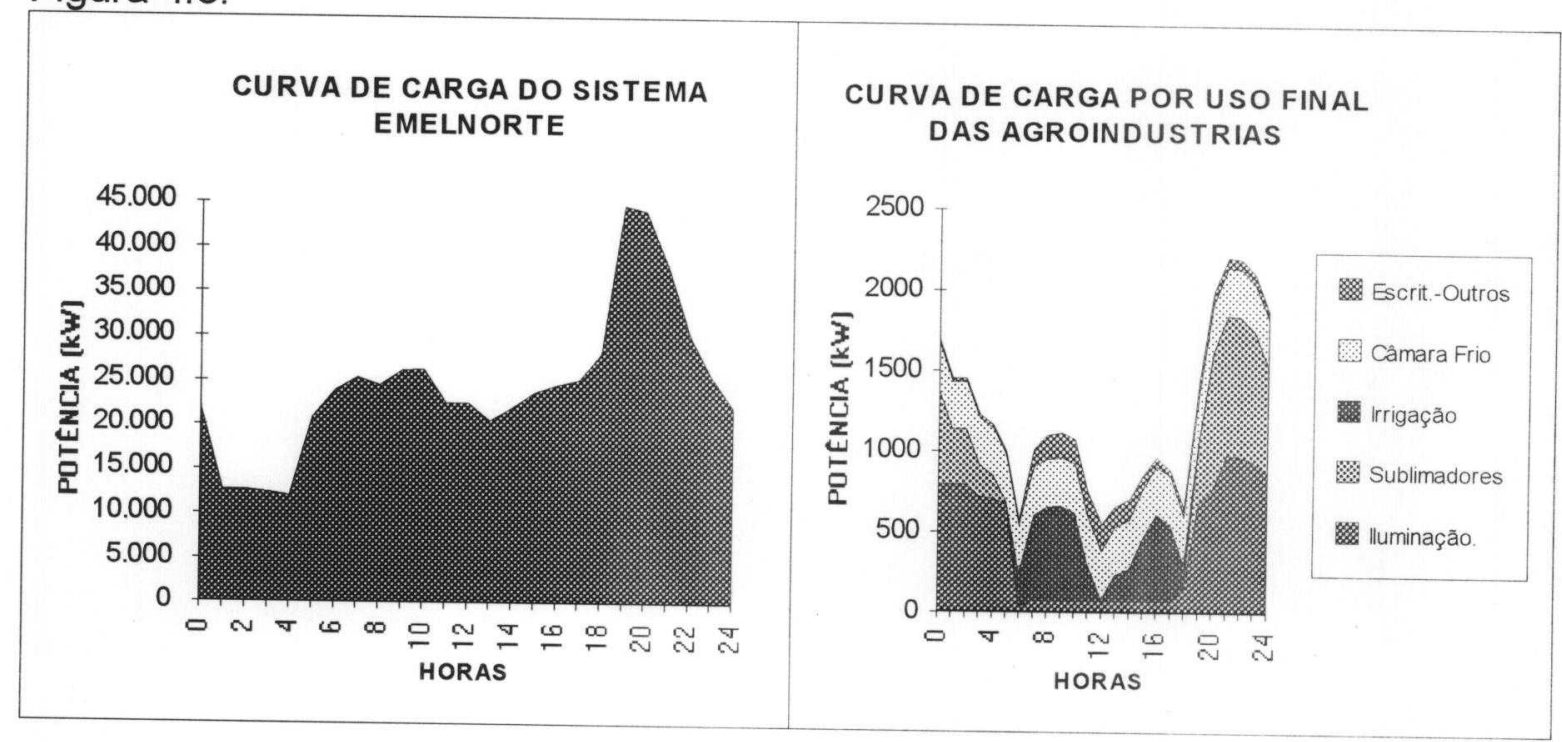

Fazer uma análise do comportamento de cada um dos usos finais na curva de carga da concessionária resulta difícil, devido a que a representatividade do setor agro-industrial é pequena, a potência máxima alcança 2,2 MW as $21 \mathrm{~h}$, portanto representa os $5 \%$ do pico da concessionária.

Porém serão colocados os resultados do comportamento de cada uso final, como mostra a Tabela 4.3. O uso final de maior potência é a iluminação, o pico de demanda máxima $985 \mathrm{~kW}$ ocorre às $21 \mathrm{~h}$, este uso final utilizado diariamente das 
$18 \mathrm{~h}$ até as $5 \mathrm{~h}$, nas agroindústrias que precisam de iluminação no processo produtivo.

Os sublimadores apresentam uma demanda máxima de $865 \mathrm{~kW}$ no período das $20 \mathrm{~h}$ até as $22 \mathrm{~h}$, o uso diário deste aparelho nas agroindústrias que tem cultivo de rosas vai desde às $18 \mathrm{~h}$ até às $5 \mathrm{~h}$.

Os sistemas de irrigação apresentam dois períodos de operação: o primeiro período de $6 \mathrm{~h}$ até as $11 \mathrm{~h}$, onde a potência máxima $576 \mathrm{~kW}$ ocorre as $9 \mathrm{~h}$, no segundo período de $15 \mathrm{~h}$ até $18 \mathrm{~h}$, a potência máxima $535 \mathrm{~kW}$ ocorre às $16 \mathrm{~h}$.

O comportamento das câmaras de refrigeração tem uma potência constante de $298 \mathrm{~kW}$ durante as $24 \mathrm{~h}$.

Finalmente o uso em escritórios e serviços gerais: o período de maior uso vai das $7 \mathrm{~h}$ até $14 \mathrm{~h}$, a demanda máxima é $168 \mathrm{~kW}$ e ocorre ao meio dia, porém fora destas horas também o uso permanece ligado, mas a carga é mínima.

Tabela 4.3 DEMANDA MÁXIMA POR USO FINAL

\begin{tabular}{|l|c|}
\hline \multicolumn{1}{|c|}{ USO } & $\begin{array}{l}\text { Demanda } \\
\text { Máxima } \mathrm{kW}\end{array}$ \\
\hline Iluminação & 985 \\
Sublimadores & 865 \\
Irrigação & 576 \\
Câmaras de refrigeração & 298 \\
Serviços Gerais. & 168 \\
\hline
\end{tabular}

\subsection{QUALIDADE DO SERVIÇO ELÉTRICO}

\section{-Análise da rede de distribuição}

A partir da década dos anos 70 , em todo o país iniciou-se a execução de programas de eletrificação rural, com o propósito de melhorar as condições de vida dos habitantes rurais, dotando-os dos serviços básicos, OLADE (1993). 
A eletrificação rural foi realizada com extensões de linhas e redes a partir das redes de distribuiçao existentes na época, a construção foi feita com condutores de baixo calibre, que pudessem suportar a reduzida carga residencial rural que consistia basicamente na iluminação e o uso de rádio.

Os programas de eletrificação não levaram em conta o potencial de desenvolvimento agropecuário da região, que naquela época não era esperado. O fornecimento do serviço desde redes subdimensionadas e sobrecarregadas, causa um atendimento deficiente nas agroindústrias, especialmente nas horas pico, já que as linhas não foram contruidas para atender uma carga industrial. Desta forma se registram-se quedas de tensão de 210 para $190 \mathrm{~V}$, como tensão de serviço.

Paralelamente ao desenvolvimento agropecuário, a concessionária fez muitos esforços para priorizar o melhoramento das redes que fornecem o serviço a este setor.

O maior desenvolvimento agroindustrial do cultivo de flores, tem-se nos cantões Pedro Moncayo e Cayambe, um total de 28 agroindústrias localizadas nestes cantões. Esta região é atendida pela EMELNORTE a partir da subestação Cayambe. No mês de março de 1994 o transformador de 7,5 MVA foi trocado por um transformador de 12,5 MVA, foram aumentados os alimentadores primários e modificada a rede de distribuição de Cayambe. A nova subestação dispõe de 5 circuitos primários a $13,2 \mathrm{kV}$, quatro destes circuitos percorrem o cantão Cayambe e o quinto é exclusivo para o cantão Pedro Moncayo.

As agroindústrias do cantão Cayambe, atualmente recebem o serviço elétrico de ótima qualidade, devido às melhoras na subestação e sistema de distribuição. 
Para o cantão Pedro Moncayo, ainda o serviço elétrico é deficiente, a rede de distribuição não foi melhorada posto que a concessionária tem planejado a instalação de uma subestação no centro de carga do cantão Pedro Moncayo.

O Figura 4.7 apresenta o alimentador para o cantão Pedro Moncayo. 0 circuito é radial, trifásico a 13,2 kV. Depois de percorrer $7 \mathrm{~km}$ (nó 1) tem-se a primeira derivação para um grupo de agroindústrias, $11 \mathrm{~km}$ mais adiante tem-se as derivações desde o circuito principal (nó de 2 até 6) para um grupo de agroindústrias, que encontram-se próximas entre elas. Depois o circuito avança até a agro indústria FLOREMIT mais longe (nó 7) a $20 \mathrm{~km}$ desde o centro de carga deste circuito. FLOREMIT é a maior agroindustrial, tem contratada uma potência de $450 \mathrm{~kW}$.

Figura 4.7 CIRCUITO PRIMÁRIO PARA O CANTÃO PEDRO MONCAYO

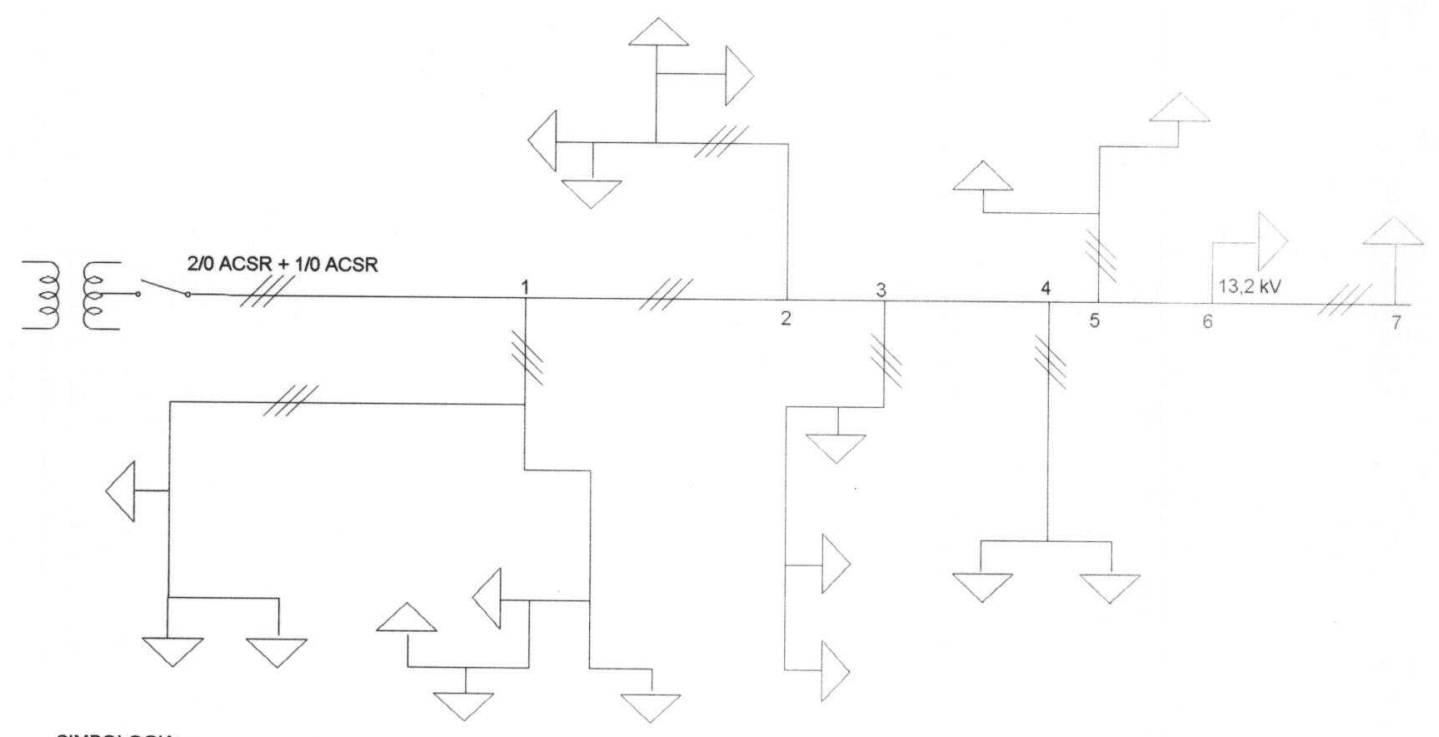

SIMBOLOGIA:

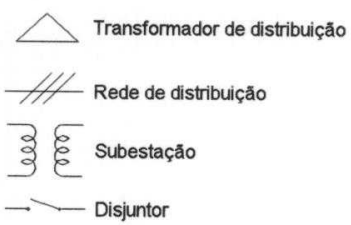


A rede principal é trifásica, construída com calibre 2/0 ACSR para as fases e 1/0 ACSR para o neutro. A maioria das derivações em alta tensão são trifásicas.

Devido à origem do sistema elétrico equatoriano, que se formou a partir de um grande número de pequenas concessionárias isoladas, não existe um padrão uniforme quanto a projetos e especificações de componentes. Isto gera uma grande variedade de equipamentos diversos que inclusive não permite a padronização das tensões secundárias. Por exemplo: os transformadores monofásicos freqüentemente usados para o serviço das agroindústrias são de potências nominais: $7.5 ; 10 ; 15 ; 25 ; 37.5 ; 50$ kVA, tensão de serviço 220/110 V. Os transformadores trifásicos utilizados são de 15; 30; 45; 50; 75; 100; 112.5; 125 kVA, tensão nominal em baixa de 210/121; 220/127; 208/120 V

Dessa maneira se registra uma forte variação da tensão nominal, no caso de $110 \mathrm{~V}$ a tensão variar de 110 até $127 \mathrm{~V}$, portanto com uma faixa de variação de $10 \%$. No caso de $220 \mathrm{~V}$, a variação vai de 210 até $220 \mathrm{~V}$, portanto é de $5 \%$. Se a essa variação de tensão nominal adicionarem-se as oscilações da tensão devido a circuitos compridos podemos verificar variações de tensão de até $13 \%$. Portanto se prejudica o uso eficiente da energia em todos os equipamentos sejam resistivos e indutivos.

As $4(10 \%)$ agroindústrias localizadas em Otavalo, são atendidas a partir da subestação Otavalo, que também é uma subestação bastante nova, cujos alimentadores primários a 13,2 kV são construídos com calibre de condutor para suportar a carga industrial.

As agroindústrias pertencentes aos cantões Ibarra (INFLOREX) e Cotacachi (AGRISAMA) são atendidas mediante circuitos primários a $6.2 \mathrm{kV}$ e $13.2 \mathrm{kV}$ que originam-se na central diesel em Ibarra. O serviço que recebem estas agroindústrias é crítico, porque as agroindústrias encontram-se nos extremos de 
cada alimentador. São alimentadores bastante compridos, no caso de AGRISAMA o alimentador percorre a cidades de Atuntaqui e Cotacachi, num total de $45 \mathrm{~km}$.

\subsection{TARIFAS}

\subsubsection{Teoria e prática dos projetos elétricos das agroindústrias}

Conforme o regulamento interno da EMELNORTE, para que uma agro indústria receba o serviço elétrico, ela deve apresentar um pedido de ligação à concessionária, dependendo da demanda contratada serão observados dois procedimentos:

1.- Se a carga a ser instalada é menor de $10 \mathrm{~kW}$, a EMELNORTE concede o serviço diretamente a partir da rede de distribuição em baixa tensão, com um padrão de cabos e medidores dimensionados para essa carga.

2.- Se a carga for superior a $10 \mathrm{~kW}$, a agro indústria deve apresentar à "Dirección Técnica" da concessionária um projeto, que detalhe a rede interna de distribuição, as caraterísticas dos componentes e as demandas de potência que ela necessitará para seu normal funcionamento. O corpo técnico da concessionária poderá avaliar a qualidade e a conformidade com as normas. Aprovado o projeto, o usuário poderá começar as obras. Antes da ligação a EMELNORTE realizará a fiscalização, para verificar o cumprimento do projeto originário e a instalação dos contadores de energia. Desta forma a concessionária garante a execução do projeto com as normas técnicas, que asseguram uma boa qualidade da alimentação.

A seqüência descrita, que é obrigatória para conseguir o serviço elétrico, não é respeitada pela maioria das agroindústrias por duas razões básicas:

a.- A maioria das agroindústrias surge como pequenas empresas, não estruturadas adequadamente, sem grandes recursos de capitais, portanto tendem 
a minimizar os investimentos. As agroindústrias iniciam as atividades com cargas inferiores a $10 \mathrm{~kW}$, recebendo o serviço elétrico a partir dos circuitos de distribuição em baixa tensão, diretamente das redes da concessionária.

Conforme a agro indústria aumenta sua área de cultivo, a necessidade de equipamento elétrico também aumenta, portanto é solicitada à concessionária a instalação de um transformador para uso exclusivo.

b.- A dinâmica do setor é elevada, após a primeira instalação, quase em forma de teste, as pequenas empresas agroindustriais vão crescendo, aumentando as necessidades elétricas. Esta dinâmica de expansão da área de cultivo se faz por etapas, geralmente apresentam-se as seguintes situações:

- Uma vez aprovado o projeto, se constroe uma parte e paulatinamente é completando o projeto, conforme as necessidades.

- A instalação de transformadores não corresponde ao projeto original, pois são instalados de menor ou maior capacidade à especificada, posteriormente são trocados para as capacidades solicitadas.

- O projeto é apresentado e aprovado com transformadores de distribuição trifásicos, no momento da execução instalam transformadores monofásicos de maneira "provisória".

- Outra situação: depois de construir o projeto conforme à verificação da EMELNORTE, são prolongadas as redes de distribuição interna e instalados novos transformadores.

Uma prática comum das agroindústrias é a construção das redes internas sem nenhuma informação prévia à concessionária. As instalações são tecnicamente deficientes e para conseguir a aprovação se exercem mecanismos de pressão, inclusive de caráter político. 
Uma vez atingidas as solicitações, caraterizadas pelas situações antes mencionadas, se passa a legalizar a relação de consumidor do serviço elétrico. Cada novo transformador é registrado com um número de conta ou código, que permita emitir a faturação correspondente e integrá-lo ao cadastro de consumidores do serviço industrial (ID). Naquelas agroindústrias que instalam o sistema de irrigação exclusivamente desde um transformador, a tarifa designada para esse tipo de serviço é de bombeio de água, então elas passam a ser registradas pela concessionária como um usuário do serviço de bombeio de água (BA). O bombeio de água está sujeito a tarifa especial, na maioria de agroindústrias que em teoria diz ter os sistemas de irrigação desde o transformador. Na prática, porém, em muitos destes transformadores são ligadas as cargas que não tem a ver com o bombeio de água.

Esta maneira de expansão das agroindústrias faz que se tenha como consumidores do sub-setor flores 55 consumidores e no setor de bombeio de água estão incluídas as 14 contas das agroindústrias registradas com tarifa BA. Em resumo, se tem 69 contas contra 39 empresas efetivas, portanto com uma média de 1.76 medidores por consumidor.

A série de situações faz com que para a concessionária, o desenvolvimento da rede rural se apresente bastante caótico, sem possibilidades de previsão no aumento da carga. Por exemplo, uma floricultura pode apresentar uma demanda superior à demanda de um povoado inteiro.

O dinâmico crescimento das instalações nas agroindústrias, com o tempo cria situações difíceis do ponto de vista elétrico, observa-se a instalação de até 6 transformadores monofásicos de $100 \mathrm{kVA}$, ao final de um circuito primário.

A instalação, por etapas dos transformadores faz com que a concessionária não possa instalar um sistema efetivo de medição. Este fato é 
grave do ponto de vista técnico e do ponto de vista tarifário.

As falências no serviço elétrico devem-se em grande parte a uma falta de comunicação entre a concessionária e os usuários, e à incapacidade de convencer aos usuários que a qualidade dos projetos elétricos é de interesse das duas partes.

A prática de sempre conseguir a aprovação dos projetos de expansão, faz que a própria agro indústria seja a primeira penalizada, porque causa uma alimentação inadequada e o sistema de distribuição perde confiabilidade, então ocorrem contínuas interrupções da alimentação elétrica (praticamente todas as agroindústrias são obrigadas a manter pequenos geradores térmicos de emergência), também os equipamentos apresentam diminuição da sua vida útil, devido às fortes flutuações da voltagem.

\subsubsection{Tarifas de fornecimento}

Dependendo da potência contratada e finalidade do uso da energia, os consumidores podem estar sujeitos a 3 tarifas: Indústrial sem demanda (I), industrial com demanda (ID), e bombeio de água (BA) ${ }^{5}$

Industrial sem demanda (I.)- Válida para usuários alimentados em baixa tensão, com demanda máxima menor a $10 \mathrm{~kW}$.

O faturamento de energia $(E)$ é realizado com tarifa monômia, na base de uma componente variável de 76.36 US\$/MWh.

\footnotetext{
5 Os preços por energia, potência e taxas de impostos são expressos em dolares US\$, ao valor do dolar de 2.260 sucres por dolar $(1 \mathrm{US} \$=\mathrm{S} / 2.260$ ).
} 
A título de impostos complementares na conta incluem-se os seguintes acréscimos: Taxa de iluminação pública, 11\% do montante por energia. "Fondo rural urbano marginal", $10 \%$ do montante por energia. Bombeiros, uma quantidade fixa de 1,33 US\$ por fatura.

A cobrança de impostos dentro da conta do consumo de energia, desvirtua o sentido da cobrança, encarece a planilha de 76.36 US\$/MWh para 92,39 US\$MWh.

Industrial com demanda (ID).- Válida para usuários alimentados em baixa e alta tensão, com demanda superior a $10 \mathrm{~kW}$. Se bem a estrutura tarifária equatoriana estabelece o pagamento de uma tarifa binomial, a maioria de medidores não tem registro de demanda, o faturamento da demanda portanto é realizado por estimativa. Quando existe medidor de demanda, esta é faturada pelo maior valor registrado nos últimos 12 meses a um valor de 2.65 US $\$ / \mathrm{kW}$. Quando não existe medidor de demanda a potência é faturada como a soma de todas as potências nominais dos equipamentos instalados, recebendo um pequeno desconto, portanto o preço por demanda é 2,31 US\$/kW.

O faturamento se realiza na base de uma componente variável de 70,37 US\$/MWh e a componente por demanda indicada no parágrafo anterior.

A título de impostos complementares na conta incluem-se os seguintes acréscimos: Taxa de iluminação pública, $11 \%$ do pagamento por energia mais potência. Fondo rural urbano marginal, $10 \%$ do pagamento por energia mais potência. Bombeiros, uma quantidade fixa de 1,330 US $\$$ por fatura.

Segundo a planilha ID, o usuário além de pagar pelo preço da energia 70,37 US $\$ / M W h$, tem acréscimo dos impostos $21 \%$ no preço por $\mathrm{MWh}$, totalizando o pagamento de 85,15 US $\$ / M W h$. 
Bombeio de água BA .- Válida para usuários alimentados em baixa e alta tensão, sem limites de potência.

O faturamento realiza-se na base de uma componente variável de 5752 US $\$ / M W h$ e uma componente de 2,10 US $\$ / \mathrm{kW}$ de demanda.

Os impostos agregados nesta tarifa são similares às outras tarifas a exceção do pagamento da taxa do "Fondo rural urbano marginal". Portanto. o preço da fatura tem um acréscimo, sendo o preço final 63.84 US $\$ / M W h$.

O Fondo rural urbano marginal é a taxa que os lisuários pagam para financiamento de eletrificação rural. Este pagamento representa para a concessionária um retorno do investimento das redes rurais. A demanda de energia para as agroindústrias, justifica a execução de projetos de desenvolvimento rural.

A taxa por iluminação pública que é cobrada aos usuários, é uma transferência da dívida que os Municípios mantém com a concessionária pela iluminação de ruas, avenidas, parques, etc, porque os Municipios como acionistas da concessionária, consideram a forma idônea de cobrar aos usuário diretamente.

Por norma da concessionária, ligações acima de 300 kVA deveriam ser medidas em alta tensão, porém poucas empresas apresentam esta medição, porque no momento que instalam os novos transformadores cada transformador novo é considerado um usuário, com sua própria medição. Esta situação acontece porque a atual tarifa não apresenta preços diferenciados por faixa de tensão e para o usuário não existe incentivo em instalar uma única medição em alta tensão.

A política tarifária atual não incentiva a otimizar o fator de carga por parte dos usuários industriais, saindo das horas pico e achatando a curva de demanda. 


\subsubsection{Análise da tarifa horo-sazonal}

A estrutura tarifária equatoriana atual, é uma tarifa binômia, o preço por kWh não corresponde ao seu custo de produção, o preço não varia com o nível de tensão, não tem diferença no horário de utilização.

As agroindústrias apresentam um consumo mais acentuado no período compreendido entre as $18 \mathrm{~h}$ e as $22 \mathrm{~h}$, após este horário, o consumo decresce.

O sistema horo-sazonal visa cobrar preços justos dos usuários de modo a cobrir os custos marginais do sistema elétrico bem com uma modulação no perfil de consumo de modo de achatar o pico de demanda, uniformizar a demanda durante o dia, (CESP 1993).

A nova proposta tarifária a custo marginal prevê preços distintos dependendo da tensão de alimentação e acima de uma determinada potência instalada, o usuário poderá optar por uma tarifa horo-sazonal, (INECEL-DECTA 1992). Os registros dos valores das demandas e consumos nos horários de ponta e fora de ponta, e nos períodos secos e úmidos, serão obtidos através de medição específica a ser instalada sob responsabilidade da EMELNORTE.

Ao aplicar-se a proposta tarifária horo-sazonal as indústrias floricultoras poderiam diminuir sua demanda nas horas pico, tendo como vantagem diminuir o preço da planilha, portanto os custos de produção. A diminuição de demanda na ponta desloca carga para períodos de menor custo.

A estrutura tarifária baseada em custos marginais é importante, na medida em que as tarifas por segmentos horários e sazonais conduzem à eficácia do fornecimento e do uso de energia elétrica, (INECEL - DECTA 1992).

Os resultados da implantação da estrutura tarifária horo-sazonal, se traduz em otimização da curva de carga do sistema, deslocando energia para horários de menor demanda. Para os usuários a estrutura tarifária horo-sazonal estimula o 
uso racional de energia fazendo que eles gerenciem a curva de carga, alterando o preço médio do kWh, obtendo um preço justo de acordo com sua forma de utilizar a eletricidade.

\subsection{CONCLUSÕES}

Neste capítulo foram abordadas as responsabilidade, que deve cumprir tanto a concessionária quanto as agroindústrias.

- Por parte da concessionária, o fornecimento do serviço elétrico tem que ser de ótima qualidade; se este é inadequado, com amplas variações da voltagem, é difícil estabelecer programas de conservação de energia com equipamentos eficientes.

- A utilização de equipamento eficiente não faz que o serviço de fornecimento melhore, pelo contrário o funcionamento do mesmo passa a ser inadequado e inclusive com possibilidade de reduzir sua vida útil.

- É também responsabilidade da concessionária a cobrança da tarifa. Assim, no caso da tarifa por bombeio de água (BA), foi observado que em todas as agroindústrias faturadas com esta tarifa, o uso da energia não é exclusivamente para tal propósito; portanto, é recomendável que a concessionária faza uma revisão da correta aplicação da estrutura tarifária. 
- Por outro lado é responsabilidade dos consumidores, apresentar os projetos prévios a sua execução para revisão por parte do pessoal técnico da concessionária. Eles devem ser apresentados desde sua fase preliminar, cumprindo com as especificações que a EMELNORTE exige, para garantir um serviço confiável.

- Por iniciativa própria dos consumidores é difícil conseguir que a demanda nas horas pico seja trasladada às horas da madrugada. A implantação da nova estrutura tarifária, incentivará aos consumidores a modificar os padrões de consumo e conseqüentemente lograr um melhor gerenciamento e operação dos equipamentos instalados. 


\section{APRESENTAÇÃO DA PESQUISA DE CAMPO}

A pesquisa de campo realizada em janeiro de 1994, contou com o apoio e recursos da EMELNORTE. De fato os programas de conservação de energia são de interesse da concessionária, a fim de liberar potência de seu sistema a custos menores que os custos de expansão do sistema elétrico.

Por outro lado a pesquisa foi bem recebida pelos usuários, que concordaram em buscar as melhoras do uso da energia.

A pesquisa permite um diagnóstico real da utilização da energia elétrica no processo produtivo agroindustrial. Chegar até o consumidor para levantar os dados, facilita constatar as instalações de maneira verbal e visual.

A cobertura da pesquisa alcançou todos os consumidores agro industriais de cultivo de flores servidos pela EMELNORTE, sendo pesquisados os usos finais, seus modos de operação, as tecnologias aplicadas. Com os resultados obtidos é possível avaliar a participação do setor agro-industrial no consumo global da concessionária. Além disso foi possível conhecer os índices de potência e consumo por mês e por hectare em cada tipo de cultivo.

\subsection{METODOLOGIA DA PESQUISA}

Com o propósito de conhecer a utilização da energia elétrica nos consumidores agro industriais, foi realizada a pesquisa de campo, sendo levantadas as caraterísticas nominais dos equipamentos elétricos, assim como os períodos de uso diário, mensal e anual.

Os equipamentos básicos utilizados em todas as agroindústrias, tanto para o processo agronômico, quanto para a conservação do produto final são: 


\section{Sistema de irrigação}

2. Câmaras de refrigeração

3. lluminação, nas espécies de flores sujeitas a fotoperiodismo

4. Sublimadores, no cultivo de rosas.

\section{Escritórios e serviços gerais}

Para avaliar a informação, classificou-se as agroindústrias pelo tipo de cultivo, identificando a responsabilidade de cada uso final. Foram construidas as curvas de carga de cada uso e colocadas na curva de carga da EMELNORTE, como mostra a Figura 4.6 na qual pode-se apreciar a participação do setor agroindustrial.

Após calcular os consumos a partir da pesquisa foram comparados com os consumos históricos, registrados na concessionária. Finalmente se fez comparação da potência contratada com a potência instalada.

\subsubsection{Descrição do questionário}

$\mathrm{Na}$ maioria das agroindústrias em que se registram mais de um transformador, o objetivo da pesquisa foi avaliar cada agro indústria de maneira global, sem fazer uma análise por transformador ou número de conta do consumidor.

O questionário foi elaborado, para conseguir a maior informação possível das características dos equipamentos; suas horas de utilização diária e o planejamento de produção, que está relacionado com a utilização dos equipamentos elétricos.

Basicamente o questionário está dividido em 3 seções (ver Anexo C). A primeira seção abordou os aspectos gerais das agroindústrias; tais como: nome, endereço, tipo de cultivo ou espécie de flor, superfície cultivada por espécie, 
número de funcionários. Nesta seção do questionário foi também incluída, a informação do consumo médio mensal registrado no medidor de energia correspondente ao ano 1993 e a potência contratada à concessionária, por parte da agroindústria.

A segunda seção, apresenta a evolução da rede de distribuição interna. Como foi explicado no capítulo anterior, o incremento dos transformadores é uma característica da dinâmica da maioria das agroindústrias. Os dados coletados nesta seção foram: a capacidade dos transformadores de distribuição e a carga servida a partir de cada um deles.

$\mathrm{Na}$ terceira seção, foi realizado um inventário dos equipamentos utilizados para: iluminação, sublimadores, sistema de irrigação, câmaras de refrigeração e escritórios e serviços gerais; anotando desses usos as caraterísticas nominais e modos de operação; em continuação são especificadas as características dos equipamentos.

lluminação.- A informação coletada foi: Tipo de lâmpadas utilizadas no cultivo e na sala de abertura das flores, horas diárias de funcionamento, disposição física das lâmpadas no cultivo e na sala. Nas caraterísticas das lâmpadas foi consultado a iluminância exigida e conseguida (devido à queda de tensão), horas de vida útil e a potência nominal.

Sublimadores.- Foram anotadas as caraterísticas nominais e as horas de uso diário.

Irrigação.- Os parâmetros pesquisados do sistema de irrigação, foram: método de irrigação, frequência de irrigação, como é controlada a vazão, a distância mais longa a ser irrigada, pressão da bomba e dos orifícios, diâmetro e material das tubulações principal e laterais, períodos de trabalho das bombas. Como caraterísticas elétricas foram pesquisadas, potências nominais das bombas 
ou sucção e de distribuição.

Câmaras de refrigeração.- As informações solicitadas foram: volume da câmara, tipo e espessura do isolamento térmico, fluído refrigerante, temperatura ambiente externa à câmara, temperatura interna, umidade relativa do ar dentro da câmara, quantidade média de material armazenado e as caraterísticas elétricas de potência e voltagem nominal dos compressões, ventiladores e difusores.

Escritórios e serviços gerais.- Foram anotadas as potências nominais dos equipamento utilizados nos escritórios e os serviços gerais (iluminação de caminhos, pequenas ferramentas oficinas e outros).

Depois do inventário dos equipamentos, no questionário foi deixado um espaço para observações, onde foram anotadas experiências da operação dos equipamentos elétricos, testes praticados na iluminação das estufas, previsão de expansão do cultivo e outras informações úteis para este estudo .

\subsubsection{Seleção da amostra}

A seleção das agroindústrias a serem pesquisadas, foi realizada tendo como referência o consumo médio mensal de energia do ano 1993. Estabelecendo cinco faixas de consumo, assim: de 0 até $20 \mathrm{MWh} / \mathrm{mês}$, de 20 até $50 \mathrm{MWh} / \mathrm{mês}$, de 50 até $100 \mathrm{MWh} / \mathrm{mês}$ e superior a $100 \mathrm{MWh} / \mathrm{mês}$. A Tabela 5.1 apresenta as agroindústrias pertencentes a cada cantão por faixa de consumo

A maioria das agroindústrias estão situadas na faixa de baixo consumo. As agroindústrias de recente formação registram baixos consumos, emquanto que as agroindústrias mais antigas apresentam altos consumos. Como foi explicado no capítulo 4, isto deve-se à dinâmica de expansão das agroindústrias. 
Tabela 5.1 NÚMERO DE AGROINDÚSTRIAS POR FAIXA DE CONSUMO

\begin{tabular}{|l|cccc|}
\hline CANTÃO & \multicolumn{4}{|l|}{ FAIXA DE CONSUMO MÉDIO EM MWh/mês } \\
\hline & $0-20$ & $20-50$ & $50-100$ & $>100$ \\
\hline Cayambe & 6 & 6 & & \\
Pedro Moncayo & 15 & 5 & & 1 \\
Otavalo & 1 & 2 & 1 & \\
Ibarra & & & 1 & \\
Cotacachi & & & 1 & 1 \\
TO TAL & 22 & 13 & 3 & 1 \\
\hline
\end{tabular}

Fonte: EMELNORTE, Cadastro de consumo de energia, 1993

A pesquisa abrange o universo de todas as 39 agroindústrias servidas pela EMELNORTE. Porém quando foram depurados os dados foi preciso anular 5 pesquisas de agroindústrias da faixa de 0-20 MWh/mês e uma da faixa de 20-50 $\mathrm{MWh} /$ mês, porque os dados estavam incoerentes e não existiu a possibilidade de retornar às instalações. As pesquisas realizadas para as 33 agroindústrias cobrem mais de $85 \%$ do universo, a eliminação das 6 pesquisas não inválida os resultados obtidos, pelo contrário os resultados são confiáveis e refletem a modalidade do uso da energia elétrica de todo o universo de usuários.

\subsection{DIFICULDADES DE CAMPO}

Apesar da grande colaboração recebida pela maioria das agroindústrias, no momento da pesquisa encontrou-se algumas dificuldades, que é conveniente apresentar para entender melhor a qualidade dos dados e a necessidade de depurações. As principais dificuldades foram de 4 tipos:

1. Falta de informação técnica por parte do usuário.

2. Reticência dos usuários em declarar o uso efetivo dos equipamentos por medo de que a pesquisa pudesse servir para controlar o consumo de energia. 
3. O período no qual a pesquisa foi realizada.

4. Dinâmica das agroindústrias.

1. Falta de informação técnica por parte do usuário.

Apesar da grande capacidade técnica na área agronômica, na maioria das agroindústrias não há pessoal especializado na área de energia. De fato, as instalações dos equipamentos são realizadas por firmas externas. Faltam assim as informações específicas sobre os critérios do projeto e as caraterísticas técnicas dos equipamentos. Em muitos casos foi necessário verificar pessoalmente as caraterísticas de placa dos diferentes equipamentos.

2. Reticência dos usuários em declarar o uso efetivo dos equipamentos por medo de que a pesquisa podesse servir para controlar o consumo de energia.

Esta dificuldade é relativamente séria. Devido ao alto nível de perdas registradas na concessionária, todas as vezes que se realizam pesquisas na região, os consumidores tendem a considerar a pesquisa como uma verificação dos consumos de energia. Portanto tendem a minimizar as informações sobre o consumo e as vezes até escondem a existência de alguns equipamentos. Para superar esta situação foi necessário insistir com os usuários que a pesquisa não tinha a finalidade de fiscalizar consumos e que o estudo a realizar-se precisava de dados confiáveis.

3. O período no qual a pesquisa foi realizada.

Como foi explicado no capítulo 2, o cultivo de flores é um fenômeno estritamente sazonal, com ponta de produção máxima durante o período de inverno do hemisfério norte (de dezembro a final de fevereiro). Como a pesquisa 
foi realizada em janeiro, a data coincidiu com a época de pico da produção1. Desta forma, os pesquisados tendiam a considerar a modalidade na qual se encontravam como modalidade média de funcionamento anual. Ao momento da depuração dos dados se verificou que os consumos históricos registrados, não correspondiam aos consumos calculados; eles guardam relação com os máximos consumos registrados. Por esta razão, na depuração dos dados foi considerado como consumo médio (das agroindústrias em expansão), o obtido dos 3 últimos meses do ano 1993.

4. Dinâmica das agroindústrias.

Como foi indicado no capítulo 4 as agroindústrias estão registrando uma taxa anual de crescimento do consumo de $63 \%$ e as agroindústrias novas tendem a registrar uma taxa ainda superior. Esta situação provoca dois problemas: 0 primeiro, é que os consumos históricos das agroindústrias em expansão são insuficientes para comparar a situação atual, já que existem novos equipamentos que vão sendo agregados. O segundo, é que nas empresas recentes, algumas instalações (especialmente as instalações fixas, como câmaras de refrigeração e sistemas de irrigação) tendem a nascer super dimensionadas, porque se prevê um aumento das necessidade futura. Desta forma os dados paramétricos (volume da câmara por hectare de cultivo ou potência do sistema de bombeio de água por hectare) tendem a registrar um forte desvio. Portanto é preciso levar em conta que algumas instalações são projetadas para atender a demanda de uma situação futura.

\footnotetext{
1 Na modalidade de pico da produção, os equipamentos operam na máxima capacidade. Em algumas agro-industrial na época de máxima produção incrementam-se os pontos de iluminação até em $30 \%$ da instalação média anual.
} 


\subsection{INFORMAÇÕES OBTIDAS A PARTIR DA PESQUISA}

\subsubsection{Análise dos usos finais}

lluminação.- A iluminação é utilizada para 0 cultivo de flores sujeitas a fotoperiodismo (como foi explicado no capítulo 2). No caso da gipsófila além do cultivo, uma fase complementar do processo, para garantir o choque do florescimento é submeter as flores cortadas a um nível de iluminação superior ao do cultivo. Portanto as flores cortadas são colocadas numa sala fechada, conhecida como "sala de abertura" das flores.

De acordo à informação da pesquisa encontrou-se tanto no cultivo quanto na sala, a utilização somente de dois tipos de lâmpadas elas são: lâmpadas incandescentes de $220 \mathrm{~V}, 200 \mathrm{~W}$, e as lâmpadas a vapor de sódio de $250 \mathrm{~W}$, ou $400 \mathrm{~W}, 220 \mathrm{~V}$.

lluminação com lâmpadas incandescentes. As lâmpadas incandescentes são distribuídas no cultivo de tal forma que se possa obter uma iluminância de 10 a 13 foot candle que é o requisito agronómico destas plantas. 0 esquema da Figura 5.1, mostra o espaçamento equidistante de $3 \mathrm{~m}$ entre lâmpadas. A altura à qual são instaladas é de $2 \mathrm{~m}$ do solo, quando a planta cresce o espaço entre a lâmpada e a topo da planta é de $40 \mathrm{~cm}$. No Anexo $\mathrm{E}$ mostra fotografias da distribuição das lâmpadas no cultivo

Como indicado no capítulo 2 a iluminação artificial pode operar em ciclos de liga/desliga. Mediante temporizadores, a quantidade de lâmpadas instaladas para iluminar uma área determinada é dividida em 3 ou 4 grupos cada qual é ligado de maneira alternada. Na Figura 5.2 encontram-se os ciclos de operação de 3 grupos. O período durante o qual cada grupo de lâmpadas permanece ligado, é critério da própria agro indústria, encontrando-se períodos de 5; 7; 10 e 
15 minutos. 0 tempo durante 0 qual todas as lâmpadas permanecem desligadas, antes que o novo grupo seja ligado varia de 1 a 5 minutos. 0 intervalo durante 0 qual todas as lâmpadas permanecem desligadas permite uma economia de energia, que será analisada no seguinte capítulo.

Figura 5.1: DISPOSIÇÃO FÍSICA DAS LÂMPADAS INCANDESCENTES NO CULTIVO DE FLORES

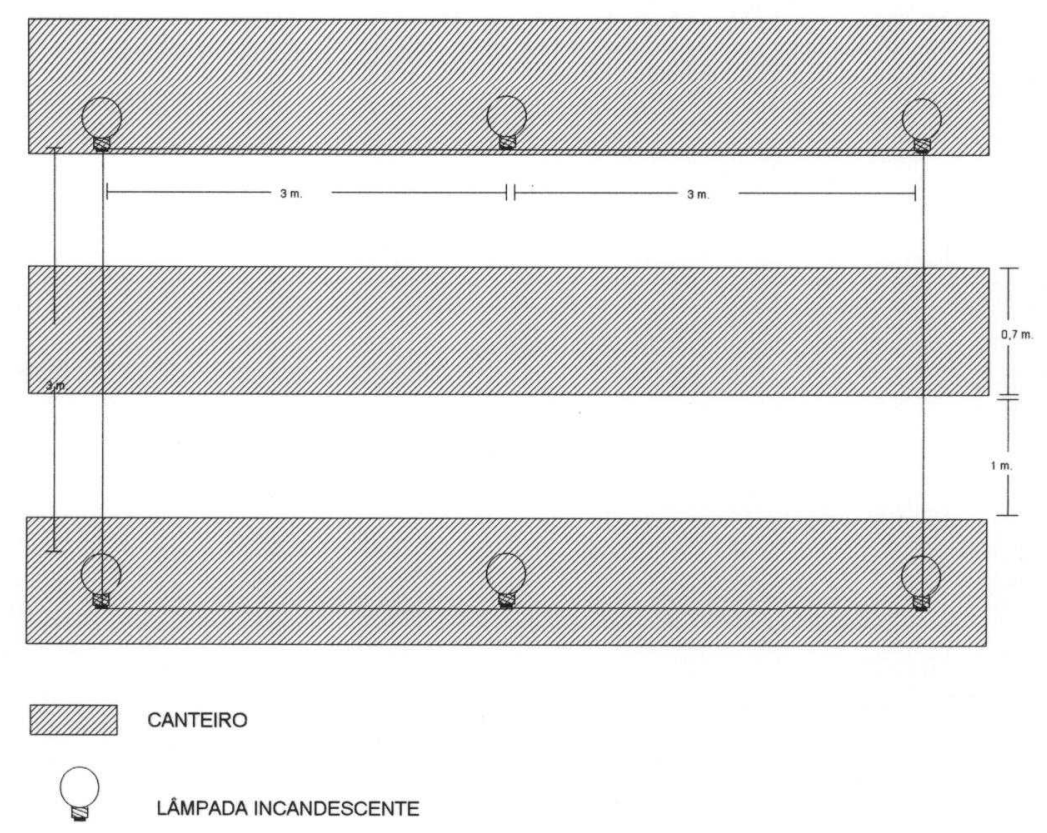

A operação cíclica liga/desliga, permite que a demanda máxima se reduza à terceira ou quarta parte da potência instalada. Dessa forma a demanda coincidente $^{2}$ diminui em 33,33 ou $25 \%$ da potência instalada. Além disso é possível uma economia de energia nos períodos de escuridão.

Ainda existem agroindústrias que não tem implementada a operação cíclica das lâmpadas, por tal motivo, elas operam com períodos de 3 ou 4 horas contínuas cada grupo de lâmpadas, mediante chaves manuais.

${ }^{2} \mathrm{~A}$ demanda coincidente é a demanda do uso final que opera simultaneamente um período de tempo. 
Figura 5.2 CICLO LIGA/DESLIGA DAS LÂMPADAS INCANDESCENTES.

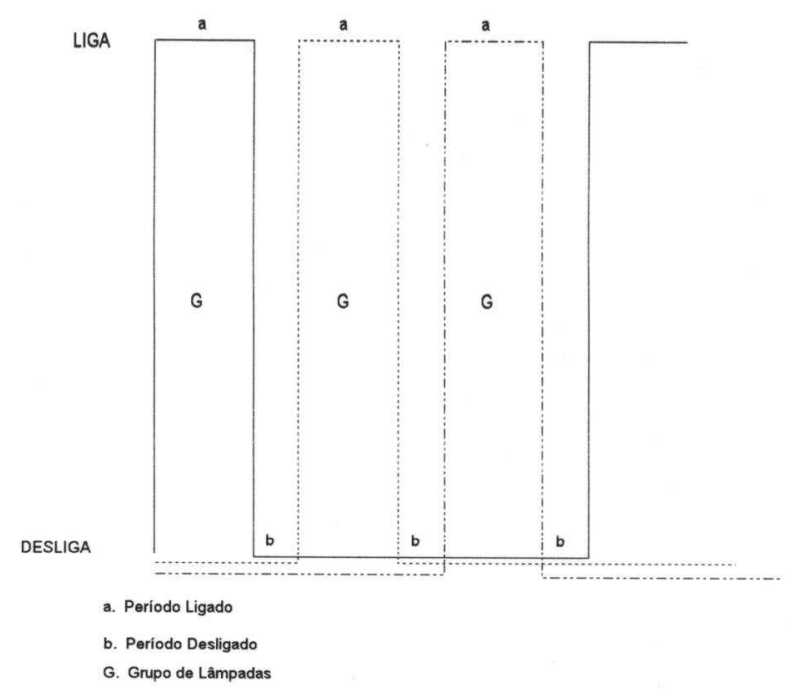

O período de fornecimento de iluminação artificial para as plantas ocorre das $18 \mathrm{~h}$ até as $6 \mathrm{~h}$. Deve-se lembrar que na região equatorial não existe uma variação significativa do comprimento do dia.

$\mathrm{Na}$ sala de abertura o requerimento de iluminação é de 15 ou $24 \mathrm{~h}$. O nível de iluminância necessária vai de 190 até 220 lux, por esta razão a disposição física das lâmpadas é de 1,4 m equidistantes entre si. Com o propósito de evitar o troco frequênte das lâmpadas se instalam duas lâmpadas juntas formando um ponto de iluminação, funcionando porém uma lâmpada por vez. Portanto, a metade das lâmpadas funcionam 12 horas e a outra metade as outras 12 horas.

A vida útil das lâmpadas, de acordo com a informação do pessoal de manutenção, está na faixa de 600 até 800 horas, não se cumpre conforme às especificações do fabricante, que indicam 1.000 horas.

lluminação com lâmpadas a vapor de sódio.- Encontrou-se somente uma agroindústria que utilizava no cultivo lâmpadas a vapor de sódio a alta pressão de 250 e $400 \mathrm{~W}, 220 \mathrm{~V}$. As lâmpadas são colocadas dentro da estufa a 12 m de distância si, encontram-se instaladas a $4,5 \mathrm{~m}$ de altura desde o solo. A 
Figura 5.3 apresenta a disposição física das lâmpadas. O Anexo E mostra a distribuição das lâmpadas a vapor de sódio utilizadas dentro da estufa e em cultivos que realizam-se fora da estufa.

Figura 5.3 DISPOSIÇÃO DAS LÂMPADAS A VAPOR DE SÓDIO NO CULTIVO

\section{DE FLORES}

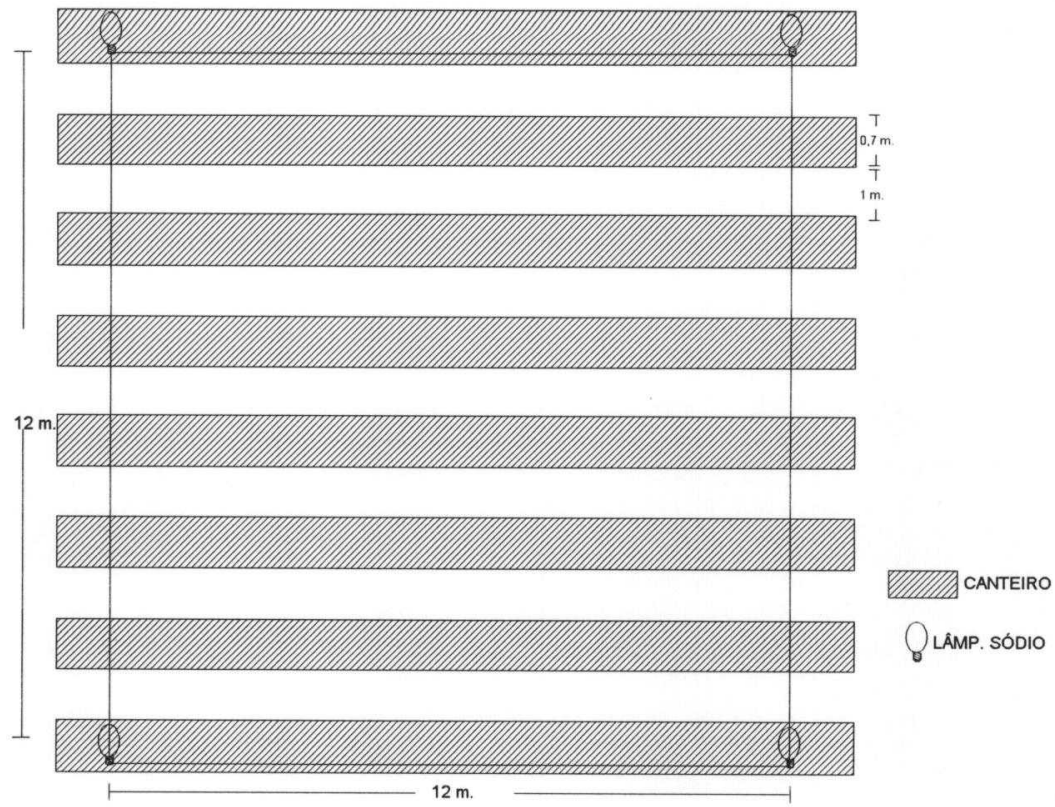

Todas as lâmpadas instaladas no cultivo operam de forma continua, durante $4 \mathrm{~h}$ diárias das 20 até as 24 horas. 0 conjunto de lâmpadas é ligado simultaneamente. Portanto, a demanda máxima é igual à potência instalada.

Em várias agroindústrias encontrou-se a utilização de lâmpadas a vapor de sódio de $250 \mathrm{~W}$ na sala de abertura. Devido a que a iluminância exigida na sala é maior, fisicamente se encontram dispostas muito perto 2,5 ou $3 \mathrm{~m}$ de distância entre elas e suspensas a $2 \mathrm{~m}$ do solo.

Em algumas agroindústrias estas lâmpadas permanecem ligadas 24 horas, mas em outras agroindústrias são ligadas somente 15 horas por dia. 
O uso de lâmpadas a vapor de sódio nas salas de abertura permite uma sensível redução da energia, já que se consegue o mesmo fluxo luminoso com uma potência de metade da necessária com lâmpadas incandescentes. Esta redução é aparente porque as lâmpadas a vapor de sódio não emitem calor, portanto é necessário colocar nas paredes da sala resistências elétricas ${ }^{3}$ para aquecer 0 ambiente de 18 até $25^{\circ} \mathrm{C}$, já que o calor é uma variável importante para a abertura das flores. Desta maniera a economia de energia proporcionada pela eficiência das lâmpadas é anulada pela necessidade de resistências usadas como fonte de calor.

Devido à pouca altura à qual as lâmpadas são instaladas tanto no cultivo quanto na sala, a área iluminada pela lâmpada é mínima com respeito à capacidade que a lâmpada tem de iluminar maior superfície quando ela é instalada a maior altura.

Em referência à vida útil, não havia por parte do usuário, um registro do tempo de vida das lâmpadas, porque a utilização destas lâmpadas é mais recente. Portanto, eles mantêm a própria informação do fabricante.

A visita às instalações mostrou a construção precária das salas de abertura, de algumas agroindústrias: o teto é feito de papelão e as paredes de plástico ou alvenaria.

Sublimadores.- Para o controle sanitário das roseiras a maioria das agroindústrias utilizam de maneira distribuída no cultivo os chamados sublimadores de enxofre. Estes aparelhos são resistências elétricas dentro de um suporte de porcelana em forma de um prato, no Anexo E mostra uma fotografia dos sublimadores. Sobre a resistência é colocado o pó de enxofre, o qual é 
sublimado com o calor da resistência quando está ligada, formando no ambiente uma atmosfera do gás de enxofre. A potência nominal desses sublimadores é de 40 W. Porém numa só agroindústria encontrou-se sublimadores de $200 \mathrm{~W}$, para tal efeito.

O período durante o qual os sublimadores permanecem ligados depende das necessidades das plantas. Se registram vários critérios, do tempo que estes aparelhos devem permanecer ligados. Porém o período médio de ligação varia de 4 até 12 horas consecutivas, sendo que todos são ligados simultaneamente. Estes elementos são ligados nas horas da noite, das $18 \mathrm{~h}$ até as $6 \mathrm{~h}$, para evitar contato dos funcionários com o gás de enxofre.

Nas agroindústrias que não utilizam os sublimadores o controle sanitário das plantas se faz com agroquímicos.

Sistema de irrigação.- A tecnologia adotada nos projetos de irrigação é uniforme, a grande maioria das agroindústrias contratam a mesma firma para compra e instalação dos equipamentos. Os sistemas de irrigação utilizados no cultivo de flores são por gotejamento e microasperção.

Desta maneira pode-se observar coincidência nos materiais e critérios de implementação, o controle da vazão, em todas as agroindústrias realiza-se com válvula volumétrica.

A pressão de trabalho das bombas está na ordem de 3 até 5 atmosferas e pressão nos orifícios de 2 até 4 atmosferas.

$\mathrm{Na}$ maioria das agroindústrias as tubulações principais apresentam um diâmetro de 4 polegadas ou $110 \mathrm{~mm}$ e as tubulações laterais, de $12 \mathrm{~mm}$ até 90 $\mathrm{mm}$. O material das tubulações é de PVC e mangueiras de polietileno para as tubulações de menor diâmetro. 
A informação sobre as potências nominais das bombas foi muito variada. Motores que vão desde 50 HP até 5 HP para as bombas de sucção e os motores para distribuição da água desde $20 \mathrm{HP}$ até $3 \mathrm{HP}$. Dependendo da quantidade de água a ser bombeada e das condições topográficas do terreno.

As horas de uso nos casos onde o processo está automatizado é de um período de 20 minutos a cada hora. 0 mesmo sistema de irrigação é aproveitado para fornecer às plantas dos fertilizantes e nutrientes. Nas agroindústrias que ainda não têm os sistemas de irrigação automatizados, a ligação das bombas depende das condições ambientais diárias. Porém o horário de irrigação é nas primeiras horas da manhã das 7 até $10 \mathrm{~h}$ e pela tarde, depois das $14 \mathrm{~h}$ até as $17 \mathrm{~h}$. Desta forma o funcionamento mínimo, médio diário das bombas é 6 horas em cada agroindústria.

Em poucas agroindústrias a distribuição da água se faz por gravidade, aproveitando a topografia do terreno, na maioria dos casos a captação de água é superficial e em poucos casos de poços profundos.

Câmaras de refrigeração.- São instalações permanentes, realizadas em alvenaria com um reforço de isolamento térmico entre as paredes, composto de chapas de poliuretano ou em alguns casos com palha de arroz.

As unidades de refrigeração são compostas por grupos herméticos ou semi herméticos de potência variável. $\mathrm{Na}$ maioria dos casos se usam unidades modulares de 3 a $7 \mathrm{~kW}$, com condensador a ar e ventilação forçada. Dentro da câmara a difusão é realizada com "fan coil", com potências que vão de 120 até $480 \mathrm{~W}$, a expansão direta do gás refrigerante (mono cloro flúor metano), com unidades modulares de ventiladores de $60 \mathrm{~W}$, atingindo uma potência total que vai de 120 a $480 \mathrm{~W}$. 
As unidades de refrigeração utilizadas são de marcas reconhecidas que garantem a qualidade e o rendimento. Apesar de todos os componentes ser de alta qualidade, não necessariamente o projeto global é eficiente. Os principais problemas encontrados durante a inspeção visual a algumas instalações foram:

- A heterogeneidade dos materiais de construção das câmaras, utilizam componentes próprios para câmaras frigoríficas, associados com materiais relativamente ineficientes. Por exemplo, a porta, típica de câmaras frigoríficas, com adequado isolamento; não obstante, o forro da própria câmara pode ser de alvenaria e sem isolamento térmico. Além disso, durante as horas de trabalho do pessoal, a porta permanece aberta, e para impedir a entrada do ar quente de fora até a câmara, coloca-se uma cortina de plástico.

- Poucos cuidados com os equipamentos: Em geral as agroindústrias não possuem técnico especializado em refrigeração, portanto, os cuidados com os equipamentos são deficientes, os condensadores, instalados em posição pouco acessível, são em geral sujos e os evaporadores apresentam depósitos de gelo.

- Não existem critérios uniformes no dimensionamento das câmaras, durante grande parte do ano eles mantêm um nível reduzido de ocupação, já que as câmaras são dimensionadas para os picos de produção. A quantidade de material armazenado, está em torno de $300 \mathrm{Kg}$ até $900 \mathrm{Kg}$ em média por dia. A permanência média do material armazenado na câmara é 48 horas.

- Algumas agroindústrias apresentam uma câmara de pré-refrigeração, onde 0 material permanece a temperatura de $4^{\circ} \mathrm{C}$. Contígua à câmara de prérefrigeração está a câmara de refrigeração, onde a temperatura é $2^{\circ} \mathrm{C}$. Porém há agroindústrias que dispõem de câmara de refrigeração a $2^{\circ} \mathrm{C}$, sem ter a câmara de pré-refrigeração. A temperatura exterior à câmara é de $14^{\circ} \mathrm{C}$, quando a câmara é construída de lado da sala de classificação das flores. Mas no caso, da câmara 
ser construída junto à sala de abertura, a temperatura desta sala chega até $25^{\circ} \mathrm{C}$.

A umidade relativa do ar dentro das câmaras é de 80 ou $90 \%$.

Para fins de cálculo do consumo de energia das câmaras de refrigeração foi estimado como fator de uso $466,6 \%$ ou $2 / 3$ do tempo os compressores estão em funcionamento. Este valor é baseado nas especificações técnicas dos fabricantes.

Escritórios e serviços gerais.- Se fez uma soma das potências nominais dos equipamentos utilizados nos escritórios, ferramentas menores, moradia do porteiro, etc. Anotando para o cálculo de energia as horas de uso dos diferentes equipamentos.

\subsection{RESULTADOS DA PESQUISA}

Como o uso do equipamento depende do tipo de cultivo, para melhor análise dos resultados classificou-se as agroindústrias em quatro grupos, assim: Primeiro aquelas que tem cultivo exclusivo de rosa. Segundo, agroindústrias que cultivam exclusivamente gipsófila. Terceiro, as que cultivam somente cravos. Quarto agroindústrias com cultivo de rosas, cravos, gipsófila e outras espécies, tais como: crisântemos, solidaster, spider e outras espécies.

Os cálculos de consumo e potência instalada de cada uso foram realizados por hectare, para ter os resultados numa unidade que permita comparar as agroindústrias dedicadas ao mesmo tipo de cultivo (ou classificadas no mesmo grupo).

\subsubsection{Balanço energético, por uso final e por tipo de cultivo.}

${ }^{4} \mathrm{O}$ Fator de uso é a percentagem que numa hora encontra-se ligada uma carga elétrica. 
- Cultivo de rosas.- Os dados paramétricos de potência e energia utilizados por hectare são apresentados nas Tabelas D. 1 e D. $2^{5}$ a demanda é 9 $\mathrm{KW} / \mathrm{ha} /$ e consumo de $2.300 \mathrm{kWh} / \mathrm{mês}$ por hectare, indicando um fator de carga de 0,35. Na Tabela D.2 se encontram os índices médios que descrevem a realidade das demandas energéticas do cultivo. Porém é importante notar que em alguns casos alterações no processo (substituição dos sublimadores de enxofre por tratamento químico, ou maior facilidade de disponibilidade de água na irrigação), podem alterar o quadro de demanda e de consumo de energia.

Dentro desses valores gerais do cultivo, a distribuição dos consumos por uso final são apresentados nas Tabelas D.3 até D.6, notando-se para cada uso os seguintes comentários:

As câmaras de refrigeração são as maiores responsáveis pelo consumo de energia, podendo ser-Ihes atribuída a responsabilidade de $40 \%$ dos consumos globais. As câmaras são também o uso final mais uniforme, sendo utilizadas por todas as agroindústrias, excetuando uma agroindústria que utiliza das instalações de outra agroindústria. A responsabilidade da refrigeração sobre o consumo de cada agroindústria varia de um mínimo de 20,4\% até uma máxima de $73,4 \%$

Os sublimadores são os segundos responsáveis pelo consumo de energia, podendo ser atribuídos os $38 \%$ dos consumos globais nos cultivos de rosas. Eles, porém não são universalmente aceitos, observando-se que em 4 agroindústrias se utilizam agrotóxicos em substituição ao enxofre, por outro lado também aquelas agroindústrias que utilizam sublimadores, registram um relativo desvio nos consumos já que os requisitos agronômicos (horas de funcionamento), variam de uma agroindústria para outra.

${ }^{5}$ As Tabelas D.1 até D.35 mostram os resultados da pesquisa de campo, são apresentadas no Anexo D 
A irrigação é o terceiro responsável pelo consumo de energia, podendo ser atribuído a ela $15 \%$ dos consumos globais. Excetuando uma agroindústria, que utiliza irrigação por gravidade, todas as agroindústrias (à exceção de uma agroindústria) utilizam eletricidade para irrigação, com uma média de potência instalada de 2,87 kW/ha, e um consumo médio de $381 \mathrm{kWh} / \mathrm{mês} / \mathrm{h} a$. A variação registrada no consumo e na potência demandada, além dos diferentes modos de operação, deve-se a diferentes situações topográficas (declividade do terreno e posição da captação) e ao diferente regime pluviométrico das micro regiões.

Figura 5.4

CONSUMO DE ENERGIA POR USO FINAL POR HECTARE DE CULTIVO DE ROSAS

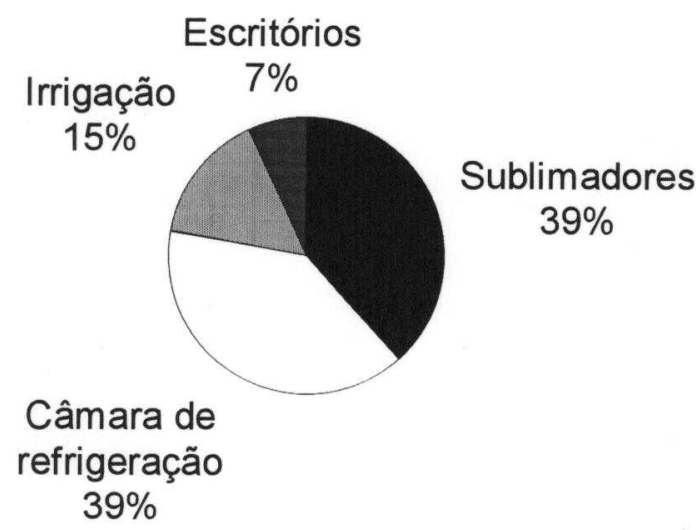

Sublimadores

Câmara de frio

Irrigação

Escritórios

O último uso final responsável do consumo é o uso de energia para escritórios e oficinas, que inclui iluminação ambiente, máquinas de escritório e pequenas ferramentas elétricas. Estes usos são responsáveis unicamente por $7 \%$ dos consumos globais, são portanto pouco significativos sobre o total.

A Figura 5.4, resume a responsabilidade de cada uso final, no consumo global do cultivo de rosas, como foi explicado anteriormente. 
- Cultivo de Gipsófila.- Neste grupo há somente 3 agroindústrias que cultivam exclusivamente gipsófila. Os dados paramétricos de potência e energia são apresentados na Tabela D.9. Por outro lado as demandas de potência e energia por hectare são apresentados na Tabela D.10, sendo a demanda 38 kW/ha e o consumo de $7.200 \mathrm{kWh} / \mathrm{mês} / \mathrm{ha}$, indicando um fator de carga de 0,26; esta última Tabela mostra as necessidades energéticas do cultivo. Porém é conveniente notar que a utilização de diferentes tipos de lâmpadas no cultivo, traz como resultado uma responsabilidade diferente de cada uso.

Para a análise de consumo de cada uso, se estimou conveniente tratar por separado as empresas que utilizam lâmpadas incandescentes daquelas agroindústrias que utilizam lâmpadas a vapor de sódio. As Tabelas D.11 até D.15 apresentam os cálculos de consumo por uso.

Cultivo de gipsófila com lâmpadas incandescentes.- A iluminação do cultivo é o maior responsável pelo consumo de energia, en torno de $70,4 \%$ dos consumos globais.

Em ordem decrescente do consumo, a iluminação da sala de abertura é o segundo uso, podendo ser-lhe atribuídos os $11,8 \%$ dos consumos globais. Observando-se dois critérios diferentes no número de horas diárias de funcionamento das lâmpadas.

A irrigação, tem uma responsabilidade no consumo global de 10,9\%. A agroindústria menor apresenta um consumo/mês/ha que é o dobro da agroindústria maior, já que a agroindústria pequena tem ao momento um super dimensionamento do sistema de irrigação.

A câmara de refrigeração é o quarto responsável pelo consumo de energia, podendo ser-Ihe atribuído $6 \%$ dos consumos globais. A menor empresa utiliza as instalações de outra agroindústria, portanto o consumo deste uso é zero para 
essa agroindústria.

Finalmente os escritórios e serviços gerais, têm uma resposabilidade baixa de 1\%. Excetuando-se a agroindústria pequena, que ainda não tem implementado esse uso.

A Figura 5.5 apresenta as percentagens de responsabilidade de consumo, quando a iluminação do cultivo de gipsófila é realizada com lâmpadas incandescentes.

Figura 5.5

CONSUMO DE ENERGIA CULTIVO DE GIPSÓFILA COM LÂMPADA

INCANDESCENTE

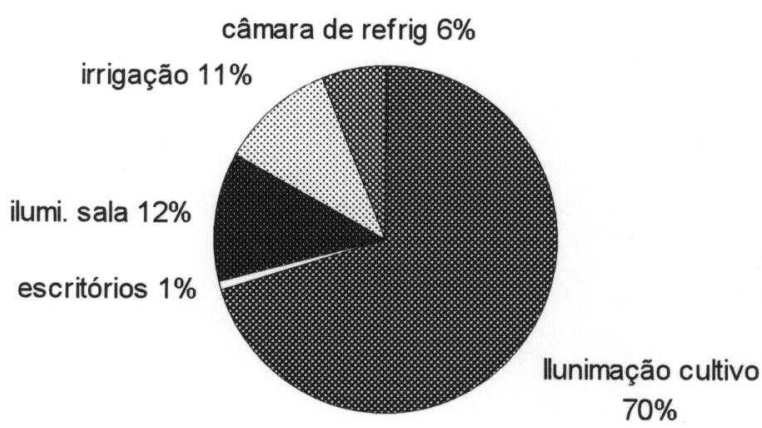

O consumo de energia mensal por hectare é $12.379 \mathrm{kWh}$, quando o cultivo realiza-se com lâmpadas incandescentes.

Cultivo de gipsófila com lâmpadas a vapor de sódio.- Fez-se a análise para a única agroindústria que utiliza lâmpadas a vapor de sódio no cultivo. A iluminação do cultivo é o maior responsável pelo consumo de energia, aproximadamente $38 \%$ dos consumos globais. 
A iluminação da sala de abertura é o segundo responsável pelo consumo de energia, podendo-lhe ser atribuído $30,2 \%$ dos consumos globais, já que nesta agroindústria a iluminação da sala se faz com lâmpadas incandescentes, sendo a potência instalada a quarta parte da potência instalada no cultivo.

A câmara de refrigeração é o terceiro responsável pelo consumo de energia, podendo ser-Ihe atribuído $16,8 \%$ dos consumos globais.

A irrigação, tem uma participação mais baixa, de $7,9 \%$ dos consumos globais.

Finalmente os escritórios e serviços gerais, têm uma responsabilidade de $7.3 \%$.

A Figura 5.6 apresenta a participação de cada uso final no cultivo de gipsófila, quando a iluminação do cultivo é realizada com lâmpadas a vapor de sódio.

Figura 5.6
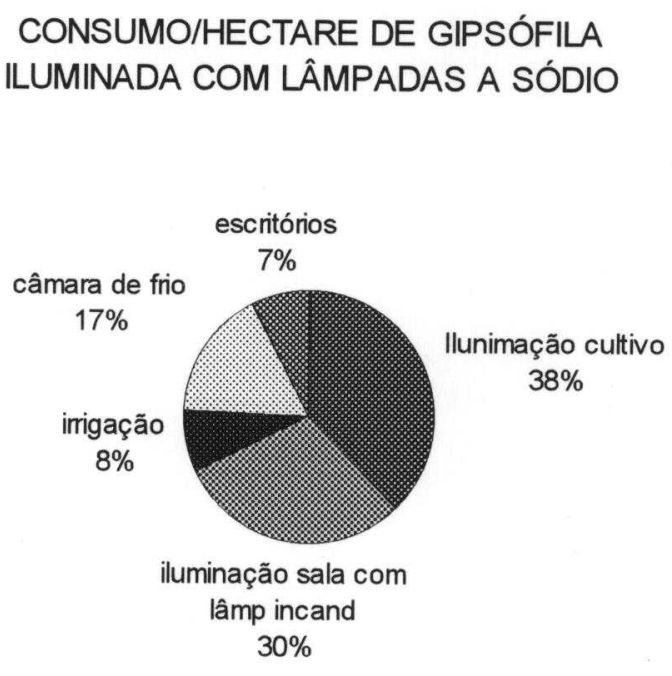

O consumo global de energia mensal por hectare é $5.186 \mathrm{kWh}$, quando o cultivo é iluminado com lâmpadas a vapor de sódio. 
- Cultivo de cravos.- Os dados paramétricos de potência e energia utilizados por hectare são apresentados nas Tabelas D.18 e D.19 a demanda é 5 $\mathrm{kW} / \mathrm{ha}$ e consumo de $670 \mathrm{kWh} / \mathrm{mês}$, indicando um fator de carga de 0,185. Na Tabela D.19 se encontram os índices médios que descrevem a realidade das demandas energéticas do cultivo. É importante ressaltar que este tipo de cultivo realiza-se em duas agroindústrias, sendo as demandas e consumos de energia por uso bastante uniforme, já que as duas agroindústrias são muito similares.

Dentro destes valores gerais do cultivo, a distribuição dos consumos por uso final são apresentados nas Tabelas D.20 até D.22, atribuindo para cada uso a seguinte participação:

As câmaras de refrigeração são as maiores responsáveis pelo consumo de energia, pudendo ser-lhe atribuída a responsabilidade de $70 \%$ dos consumos globais.

A irrigação é o segundo responsável pelo consumo de energia, podendo ser atribuído $19 \%$ dos consumos globais.

O último uso final responsável pelo consumo é o uso de energia para escritórios e oficinas, que inclui iluminação ambiente, máquinas de escritório e pequenas ferramentas elétricas. Estes usos são responsáveis unicamente por $11 \%$ dos consumos globais.

A Figura 5.7 apresenta as percentagens de responsabilidade dos três usos finais, utilizados no cultivo de cravos. 
Figura 5.7

CONSUMO DE ENERGIA POR USO FINAL
POR HECTARE NO CULTIVO DE CRAVOS

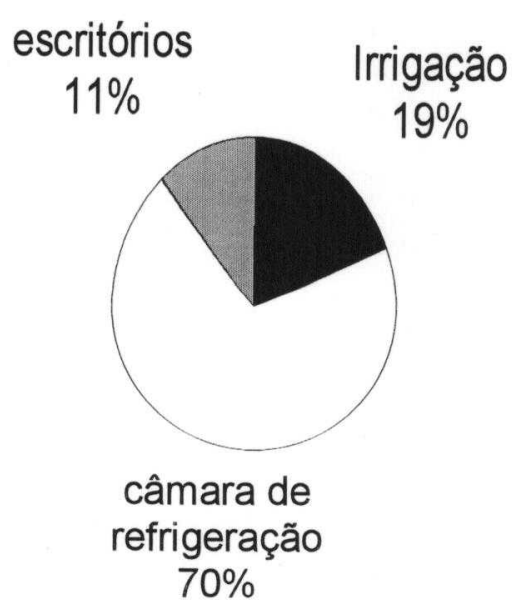

- Cultivo de várias espécies.- Os dados paramétricos de potência e energia utilizados por hectare são apresentados nas Tabelas D.25 e D.26 a demanda é $22 \mathrm{~kW}$ e consumo de $4.600 \mathrm{kWh} / \mathrm{mês} / \mathrm{ha}$, indicando um fator de carga de 0,30. Nesta última Tabela, se encontram os índices médios das demandas energéticas para as agroindústrias que cultivam várias espécies de flores. É importante levar em conta que nestas agroindústrias não existe uniformidade na utilização dos equipamentos, devido à diversidade dos processos. Desta forma, os resultados de demanda e consumo de energia do grupo variam bastante entre as agroindústrias.

Dentro destes valores gerais do cultivo, a distribuição dos consumos por uso final são apresentados nas Tabelas D.27 até D.33, sendo pertinente fazer para cada uso, os seguintes comentários: 
A iluminação do cultivo é a maior responsável pelo consumo de energia, em torno de $54,3 \%$ dos consumos globais. A iluminação do cultivo se faz com lâmpadas incandescentes, sendo utilizadas em todas as agroindústrias que precisam de iluminação. A responsabilidade da iluminação sobre o consumo de cada agroindústria vária de $7,8 \%$ até $67,3 \%$.

A iluminação da sala de abertura com lâmpadas incandescentes é o segundo responsável pelo consumo de energia, sendo atribuídos $11 \%$ dos consumos globais. Porém não são aceitos por todas as agroindústrias, existindo uma que utiliza lâmpadas a vapor de sódio e lâmpadas incandescentes e a outra agroindústria que utiliza para a iluminação das salas exclusivamente lâmpadas a vapor de sódio.

As câmaras de refrigeração são responsáveis por 10,5\% do consumo de energia global. As câmaras são também o uso final mais uniforme, sendo utilizadas por todas as agroindústrias. A responsabilidade da refrigeração sobre 0 consumo de cada agroindústria varia entre o mínimo de $7,5 \%$ até $68.7 \%$. Em todas as agroindústrias observa-se um relativo desvio nos consumos, devido à diferença de critérios na construção das câmaras.

Os sublimadores são responsáveis por $10.9 \%$ dos consumos globais, porém não são aceitos em todas as agroindústrias, uma delas tem substituído por agrotóxicos. A responsabilidade dos sublimadores sobre o consumo de cada agroindústria vária de $5,4 \%$ até $53,5 \%$. O desvio registrado no consumo, deve-se aos diferentes critérios agronômicos (horas de funcionamento), aplicados de maneira particular em cada agroindústria.

O sistema de irrigação é responsável de $10,6 \%$ do consumo de energia global. Excetuando uma agroindústria que utiliza óleo diesel, todas utilizam eletricidade para o sistema de irrigação. Este uso demanda uma potência 
instalada de 3,3 kW/ha e um consumo médio de $784 \mathrm{kWh} / \mathrm{mês} / \mathrm{ha}$. 0 desvio registrado na potência e consumo deve-se às dificuldade de extração e distribuição da água. A responsabilidade do sistema de irrigação no consumo de cada agroindústria varia de $7,1 \%$ até $31 \%$.

O uso de menor responsabilidade é o uso de energia para escritórios e oficinas, podendo ser atribuído 2,6\%, ainda que seu uso ocorra em todas as agroindústrias.

A Figura 5.8 apresenta as percentagens de responsabilidade de todos os usos finais, utilizados nas agroindústrias de várias espécies de flores.

Figura 5.8

CONSUMO DE ENERGIA POR USO FINAL POR HECTARE DE VARIOS TIPOS DE CULTIVO

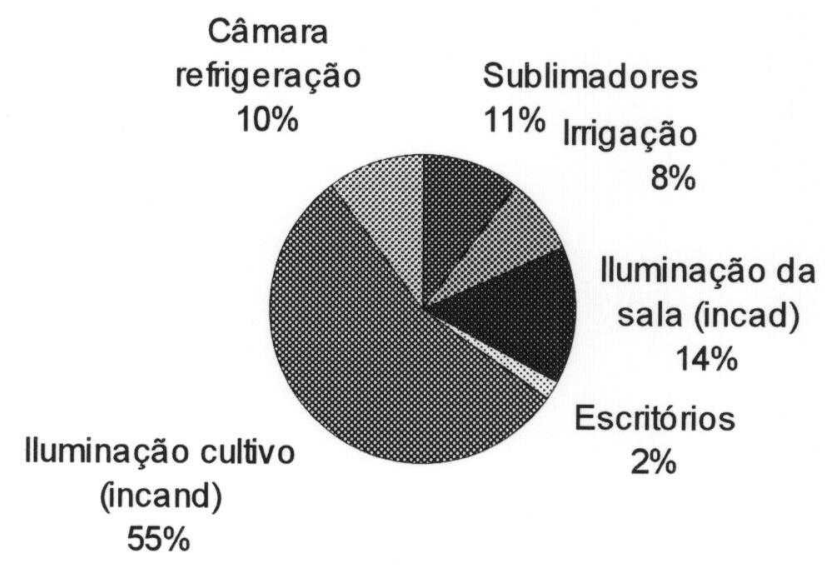

\subsubsection{Comparação da energia calculada e energia registrada}

De maneira geral para todas as agroindústrias, se procedeu a comparar o consumo calculado a partir dos dados da pesquisa com o consumo histórico, considerou-se aceito o resultado quando a porcentagem de erro é $\pm 10 \%$.

Ao consolidar a informação encontrou-se erros bastante altos em algumas 
agroindústrias do ordem do $80 \%$, estes erros deviam-se a situações particulares de cada uma delas. Portanto foi necessário uma análise individual. Em outras agroindústrias os erros deviam-se aos fatores explicados na seção 5.2 deste capítulo

Feita a análise particular das agroindústrias, os resultados estão na faixa aceitável de $\pm 10 \%$.

Nas Tabelas D.7; D.16; D.23 e D.34 apresentam-se os resultados para cada tipo de cultivo.

\subsubsection{Comparação de potência calculada e potência contratada.}

Ao comparar a potência calculada a partir da potência nominal dos equipamentos com a potência contratada à concessionária, considerou-se aceito o resultado quando a porcentagem de erro é $\pm 10 \%$.

Em quase todas as agroindústrias os valores de potência instalada superam o valor da potência contratada, em percentagens superiores a $200 \%$, como mostram as Tabelas D.8; D.17; D.24; D.35.

Esta situação deve-se à dinâmica de expansão das agroindústrias, as quais aumentam a instalação dos equipamentos de maneira progressiva. Como foi indicado anteriormente, em muitas das agroindústrias não esta instalados medidores binários e o faturamento é realizado na base da carga instalada, desta maneira penaliza á concessionária que subfaturamento a demanda contratada.

A demanda instalada em todas as agroindústrias alcança a $6.174 \mathrm{~kW}$, entanto que a concessionária fatura $3.975 \mathrm{~kW}$, obtendo-se um déficit de faturamento por demanda de $2.199 \mathrm{~kW}$ que representa o $35,6 \%$ de demanda instalada. 


\subsection{CONCLUSÕES}

Foi muito positivo chegar até os consumidores para levantar uma cadastro dos tipos de equipamentos utilizados para a produção de flores. Sendo também possivel conhecer as etapas do processo produtivo que vão acompanhadas dos períodos de uso do equipamento elétrico.

Para avaliar os dados obtidos na pesquisa, se fez uma classificação por tipo de cultivo. Como variável explicatica de comparação entre agroindústrias se definiu a quantidade de energia e potência por hectare. Porém as diferentes técnicas aplicadas apresentava desvios amplos de uma agroindústria para outra.

Os consumos de energia calculados a partir da pesquisa forão comparados com aqueles registrados na concessionária. Encontrou-se que para algumas agroindústrias os valores registrados não correspondiam a os valores calculados obtendo-se erros superiores ao $\pm 10 \%$. Esta diferença reflete a má informação proporcionado pelo pessoal que atendeu a pesquisa, ou deve-se à dinâmica de expansão das agroindústrias, elas não mantém um planejamento uniforme no ano.

De maneira similar à comparação do consumo de energia se fez para a demanda, os erros obtidos forão muito altos. Detectou-se uma subfaturação na demanda mensal de 2,2 MW. O que indica a necessidade por parte da concessionária de instalar medidores binârios, com a finalidade de ter um controle da demanda. 


\section{ANÁLISE DOS USOS FINAIS POR PROCESSO PRODUTIVO}

\subsection{SEQÜÊNCIA DOS PROCESSOS PRODUTIVOS POR TIPO DE CULTIVO.}

O processo de produção de flores é eminentemente agronômico, com um uso de energia elétrica limitado a poucos processos. Porém para ter claro o potencial de racionalização de energia é importante ter presente as sequências dos processos, já que a produtividade está diretamente relacionada com o funcionamento dos equipamentos elétricos.

No capítulo anterior foram classificadas as agroindústrias em 4 grupos de acordo com o tipo de cultivo. Dependendo do tipo de cultivo vão associados, além dos equipamentos básicos para irrigação e conservação, os sublimadores e iluminação.

Neste capítulo será descrita a seqüência dos processos para os cultivos de rosas, cravos, gipsófila e crisântemos, que são os quatro tipos de cultivos padrão quanto à utilização do equipamento elétrico.

\subsubsection{Cultivo de rosas}

O processo de produção das rosas se divide em duas partes distintas: A primeira é a produção propriamente dita, um processo agronômico no qual se usa energia unicamente para bombear a água de irrigação e para alguns processos de tratamento fito-sanitário. A segunda parte é de preparação para o transporte, na qual a energia entra só para os processos de refrigeração e conservação das flores. Paralelamente a estas atividades, todas as agroindústrias apresentam um consumo de energia para as atividades de escritórios e serviços gerais. 
Todo o processo de cultivo é realizado em estufas com estrutura em madeira roliça e cobertura com plástico transparente. 0 terreno coberto pela estufa é arado e adubado, sendo predisposta uma estrutura semi-permanente de distribuição da água com gotejadores. 0 próprio sistema de irrigação incorpora sistemas de injeção de fertilizantes. 0 plantio das roseiras é realizado diretamente no canteiro final, onde são plantadas as mudas, sendo a reprodução realizada por via vegetativa.

Entre a fase de plantio e a primeira colheita decorrem de seis a oito meses até o início da produção. Iniciada a produção a muda continua produzindo rosas por cerca de três a quatro anos, quando a muda encontra-se cansada e recebe uma poda profunda, que proporciona maior vigor vegetativo para a próxima produção (GUILLÉN 1978). Em uma região como a "serra norte" do Equador onde não se registram variações sazonais climáticas apreciáveis as mudas florescem durante todo $\mathrm{o}$ ano, porém dada a alta sazonalidade do comércio de flores com a concentração das vendas nas festas de final de ano e de São Valentim (fevereiro), a administração das estufas realiza tratos agronómicos para concentrar a produção nestes períodos. Isto é possível com a poda profunda nos períodos apropriados, com o manejo dos fertilizantes, irrigação e com tratamentos de conservação das flores.

Em condições vegetativas e climáticas normais as rosas podem exigir a reposição de uma evapo transpiração da ordem de 8 a $10 \mathrm{~mm}$ de água diária, com pontas máximas que podem atingir, em algumas regiões valores da ordem de 24 $\mathrm{mm} /$ dia, o que significa que o bombeamento de água se faz em períodos prolongados de até 11 horas diárias.

Os tratamentos fito-sanitários periódicos podem realizar-se com nebulizadores manuais que pulverizam os elementos químicos. Outro método de 
controle sanitário, para tratamento contra doenças fúngicas ${ }^{1}$, praticado na maioria das agroindústrias é utilizando enxofre, o qual é distribuido no ambiente utilizando resistências elétricas que sublimam o enxofre puro com o calor. Neste caso, o consumo de energia do processo é apreciável.

Uma vez cumprido o tempo de maturação, se procede à colheita diária das flores em botão. De forma imediata as flores recebem cuidados especiais de hidratação e fornecimento de nutrientes, já que a colheita da flor desencadeia uma série de processos metabólicos e físicos, todos eles que aceleram a morte da flor. Portanto estes cuidados proporcionam às flores resistência e podem manter sua qualidade durante a classificação, armazenamento e transporte, assegurando uma vida útil de mais de duas semanas.

Terminada a fase propriamente agronômica, as rosas são submetidas a um tratamento térmico de resfriamento que induz à florada, inibindo porém a abertura do botão. Após o processo de refrigeração, as rosas devem ser conservadas (refrigeradas) até a entrega no mercado. Então, com o novo choque térmico, novamente com o calor do ambiente a flor se abre.

Para as etapas de armazenamento e embalagem existem dois métodos, como se descrevem:

1. Depois de colocadas em uma solução de nutrientes as flores são embrulhadas fora da câmara de refrigeração. As flores são colocadas nas caixas de papelão e levadas à câmara onde resfriam-se rapidamente com a aplicação do ar forçado com ajuda de "fan coir", o qual permite injetar ar frio nas caixas através das janelinhas abertas das caixas, em 20 ou 30 minutos o conteúdo da caixa está à temperatura da câmara de frio $\left(2^{\circ} \mathrm{C}\right)$.

\footnotetext{
${ }^{1}$ As doenças fúngicas são especialmente graves em ambientes confinados como as estufas e tendem a incrementar-se durante o armazenamento e transporte, sobre tudo nos ambientes fechados da embalagem de pouca ventilação e alta umidade.
} 
2. Embalagem em seco. As flores depois da classificação são colocadas em caixas forradas de polietileno, sem pô-las em água previamente. As caixas abertas são colocadas na câmara de frio, até obter o resfriamento total, depois se fecha o polietileno, se fecha a caixa mantendo-se a temperatura entre $\pm 2^{\circ} \mathrm{C}$, com este método as flores podem durar por mais tempo.

\subsubsection{Cultivo de gipsófila.-}

Popular mente conhecida como "mosquitinho" é uma planta que dá flores pequenas, de apenas $1 \mathrm{~cm}$. Normalmente usa-se a gipsófila para dar leveza aos arranjos de flores maiores e mais vigorosas, como rosas e crisântemos.

As plantas devem receber sol pleno, porém o cultivo se realiza dentro de estufa, para evitar que fortes chuvas possam tombar as plantas, já que as hastes são muito frágeis. Cultivar a gipsófila sob coberta adiciona uma vantagem, que é a cor das flores, elas são mais brancas.

Existem variedades de gipsófila que são cultivadas fora de coberta, as flores que se obtém são branco-rosa, neste caso estas flores apresentam longa vida no vaso, o caule é mais resistente. Cultivar a gipsófila dentro ou fora da estufa depende principalmente da preferência do agricultor.

O processo de produção de gipsófila começa com a semeadura das mudas ou semente. Depois de preparar o solo com adubos, se formam as camas, que são os canteiros de $0,7 \mathrm{~m}$ de largura e de comprimento variável segundo o comprimento da estufa, onde as mudas serão colocadas nos dois lados do canteiro. 
As tabulações para a distribuição da água por gotejamento são instaladas previamente à semeadura, para que o plantio receba todos os cuidados desde 0 primeiro momento.

Após a quarta semana da semeadura as plantas já estão crescidas e são submetidas a prolongados períodos de luz, para acelerar a época do florescimento; já que a gipsófila é uma planta de dias longos, ela precisa de períodos prolongados de luz para ser induzida ao florescimento.

Para prolongar o período de luz do dia, se utilizam instalações de luz artificial. A iluminância média para estimular às plantas é 12 "foot candle". Nas agroindústrias em estudo observou-se a utilização de lâmpadas incandescentes e lâmpadas a vapor de sódio a alta pressão. Dependendo da eficiência da fonte utilizada as plantas podem receber luz artificial de 5 a 6 semanas, período no qual se consegue que sejam induzidas o florescimento.

Quando começam a aparecer os botões é suspensa a estimulação luminosa artificial, então a planta continua um crescimento vegetativo, sem ainda dar flores. Quatro semanas mais tarde são cortadas as hastes com um grande volume de botões.

A etapa seguinte ao corte é levar os botões a um processo de abertura, no qual as hastes cortadas são colocadas em recipientes com água e nutrientes para continuar seu processo vegetativo. Além dos cuidados para evitar a desidratarão, e o esgotamento dos nutrientes, ou os ataques microbiológicos, se providencia luz, com níveis de iluminância de 20 a 25 "foot candle", para garantir o choque do florescimento. Neste processo os botões permanecem no mínimo 48 horas.

Terminado o processo de abertura, as flores passam a ser classificadas e embrulhadas, para continuar com o processo de conservação, a fim de que possam ser transportadas mantendo as condições de aparência e 
comercializadas. A conservação se faz de forma similar à das rosas, e são também refrigeradas $\mathrm{a} \pm 2^{\circ} \mathrm{C}$.

Uma vez cortadas as hastes, as plantas são submetidas a um repouso vegetativo, sendo conveniente praticar uma poda profunda para que a planta tome vigor vegetativo e possa produzir flores de qualidade na próxima colheita. Aproximadamente a vida útil destas plantas é de 3 anos, depois deste período os canteiros recebem novas mudas.

\subsubsection{Cultivo de crisântemos}

Os crisântemos pertencem ao mesmo gênero botânico da margarida comum. Os crisântemos destinados ao corte precisam de cuidados especiais.

A reprodução das mudas se realiza com a colocação das estacas não raizadas em câmaras especiais a temperatura de $14^{\circ}$ a $18^{\circ} \mathrm{C}$ com $80 \%$ de umidade. Durante esta etapa de enraizamento a porcentagem de água é muito importante (GUILLÉN 1978).

Antes de transplantá-las no canteiro sob cobertura, os produtores fertilizam o solo com adubos minerais ricos em nitrogênio, tomando ainda o cuidado de desinfeta-lo contra insetos, fungos, etc.

Na cultura dos crisântemos, a iluminação tem grande importância. já que são plantas de dias curtos e florescem quando, além das condições favoráveis de temperatura, recebem um número menor de horas de luz por dia. O sistema de iluminação instalado no cultivo faz que as mudas se acostumem a receber mais horas de luz por dia. Portanto se inibe o florescimento e se permite que as mudas cresçam até alcançar maior tamanho. Este processo dura aproximadamente 6 semanas. Quando a planta apresenta um desenvolvimento adequado é retirada a 
estimulação artificial de luz, deixando que as plantas comecem a etapa de florescimento, porque o período diário de luz diminui. A iluminância suficiente para inibir o florescimento da planta é de 10 a 12 "foot candle".

As flores são colhidas com botões abertos até a metade e, em seguida passam aos galpões de classificação e embalagem, onde são resfriadas até $\pm 2^{\circ} \mathrm{C}$, permanecendo prontas para o embarque até o mercado.

\subsubsection{Cultivo de cravos}

Como a rosa, o cravo tem sido prestigiado há algumas gerações por sua beleza e perfume caraterístico.

Os caules são herbáceos e cada haste pode sustentar mais de uma flor terminal. Para ter uma flor exuberante, se suprimem os botões que brotam na mesma haste. A primeira produção se obtém depois de 3 ou 4 meses do transplante das mudas. $O$ cultivo é realizado em estufas.

O solo arenoso é mais adequado ao desenvolvimento dos craveiros, que são plantas que requerem menor quantidade de água, já que são plantas que sofrem mais com excesso de umidade do que com seca, porém ambas condições precisam estar sob controle.

Além dos cuidados comuns a todos os cultivos, os craveiros precisam de "tutoramento", para isso são enfiadas estaquinhas de madeira no canteiro, às quais as hastes são amarradas com um fio.

O cultivo de cravos torna a terra "cansada" em 2 anos de produção, sendo conveniente fazer um plantio de uma leguminosa na área, ou substituir a terra por outra, vinda de lugar onde não se tenha cultivo de cravos. 
A energia para este tipo de cultivo é utilizada em irrigação e nas câmaras de refrigeração, que realizam-se de maneira similar aos outros cultivos descritos anteriormente.

\subsection{MEDIDAS DE RACIONALIZAÇÃO DE ENERGIA}

Considerando que, num processo produtivo industrial, nenhuma medida de conservação de energia pode ser praticada se esta compromete o rendimento do processo, inclusive até poderia-se falar que um conveniente aumento da produtividade é uma boa justificativa para um aumento no consumo de energia.

A indústria de flores no Equador é recente, portanto não existe uma ampla experiência na otimização das instalações elétricas. Durante as visitas, para realizar a pesquisa foi possível verificar de maneira visual as instalações e operação dos equipamentos.

Sob tais premissas, basea-se indicar as principais diretrizes de racionalização de energia por uso final, utilizado no processo produtivo de flores.

\subsubsection{Sistemas de irrigação.}

A disponibilidade de água é uma exigência fundamental para obter-se flores grandes e sadias: a irrigação excessiva provoca o apodrecimento das flores, enquanto que a irrigação deficiente cria desidratação nos caules antes do corte. Durante $\mathrm{o}$ ano inteiro as estufas devem ser irrigadas, repondo no solo a quantidade de água absorvida pelas plantas e a evaporada (evapo-transpiração).

O consumo de energia na irrigação depende basicamente de duas variáveis: 
1. Localização da água em relação à região do cultivo, vale dizer, a altura manométrica na qual a água deve ser bombeada.

2. Necessidade de água, portanto a quantidade de água a ser bombeada por hectare.

3. Tipo de instalação (perda de carga).

1. A localização da água em relação ao espaço cultivado, pode exigir diferentes consumos de energia para a mesma quantidade de água.

2. As necessidades de água dependendo de duas condições, que são: as condições climáticas da região e as condições de vegetação da planta.

a.- As condições climáticas locais, sendo os principais fatores: a umidade relativa, a temperatura externa e o regime de ventos, já que o ar seco (com elevada temperatura e ventos) aumentam a evapo-transpiração e portanto a necessidade hídrica. Dependendo da localidade as plantas recebem a rega de 4 até 11 horas diárias.

b.- As condições de vegetação das plantas, ou seja, suas necessidades agronómicas em função das espécies, dos ciclos sazonais de produção como por exemplo o cravo, que com menor exigência de água, tem um consumo por hectare inferior ao das rosas. Durante a estação das chuvas, de dezembro até abril, a necessidade de água é diminuída, aumentando durante o período da seca, principalmente nos meses de junho, julho, e agosto, demostrado claramente o aumento da demanda de energia durante estes meses, na maioria das agroindústrias. 
3. Tipo de instalação; como se trata de sistema de irrigação por gotejo, a pressão nos goteros é baixa para que a irrigação seja mais uniforme. Devido às componentes do sistema, como são: material e diâmetro das tubulações, a extensão do reticulado influem numa perda de carga hídrica.

As Tabelas D.4; D.13; D.20; D.30; mostram os consumos de energia para irrigar um hectare das diferentes espécies de flores. Como mostram as Tabelas, a variação de consumo registrado entre as diferentes culturas e diferentes agroindústrias é relativamente ampla, por exemplo nas rosas, com uma média de $381 \mathrm{kWh} / \mathrm{mês} / \mathrm{ha}$, se registra um desvio de $122 \mathrm{kWh} / \mathrm{mês} / \mathrm{ha}$.

\section{Otimização da utilização da água.}

Os dados de campo mostram um forte desvio de consumo de energia por unidade de superfície, o que reflete em parte as diferentes práticas culturais e os parâmetros do projeto. Durante as visitas foi possível verificar que as condições de irrigação dos diferentes canteiros e das diferentes agroindústrias não é constante, é freqüente encontrar canteiros com água correndo, com níveis de saturação do solo, que já deveriam estimular a suspensão da irrigação. Por outro lado não foi encontrado em nenhuma das instalações visitadas, instrumental de medição de campo, por exemplo, não foi encontrado nenhum tanque de evaporação classe A (que é o instrumento primário para avaliar as exigências da água de uma região e o cultivo). Por outro lado, apesar de algumas instalações serem totalmente automatizadas, com ciclos automáticos de rotação da irrigação nos diferentes canteiros, não foi possivel observar nenhum sistema automático com sensores de umidade no solo, os quais pudessem controlar automaticamente a irrigação a partir das condições de campo. 
Não é possível, sem medições específicas de campo, chegar a uma avaliação definitiva sobre a qualidade das práticas de irrigação, porém a presença de água correndo nos canteiros é a primeira indicação de um excedente hídrico, obtido a custa de um dispêndio de energia. 0 extravazamento de altas quantidades de água em um curto intervalo de tempo, saturando as camadas superficiais, favorecem os escorrimentos, e a cria condições inadequadas de nutrição da planta. A capacidade de extravasamento de água por parte dos gotejadores ou dos micro aspersores deve ser tal que forneça a quantidade de água necessária, sem criar estes problemas de escorrimentos. É provável que, em grande parte, os sistemas provenham de projetos inadequados, ou que as práticas de operação não sejam corretas.

Por outro lado a experiência internacional mostra que é freqüente, quando se implanta novas tecnologias no campo, que a sua aceitação é crítica durante os primeiros anos, porque a sociedade agrícola tradicional tende a assimilar a nova tecnologia dentro dos contextos culturais das próprias tradições. No caso específico da irrigação na "sierra norte" do Equador poder-se-ia dizer que existe uma grande dificuldade cultural na assimilação das tecnologias por gotejo e por micro aspersão, já que, apesar de tratar-se de uma região na qual a irrigação tem uma tradição milenar, as técnicas tradicionais de irrigação são por alagamento, portanto a quantidade de água suprida por área é bem maior e sempre a irrigação é praticada até um nível de sobre saturação do solo. É claro que, quando se utiliza uma técnica de gotejamento e de micro aspersão, os parâmetros técnicos são totalmente distintos (a irrigação é praticada diariamente e não em ciclos de 7 ou 15 dias como na agricultura tradicional, além disso existe um uso intensivo de fertilizantes químicos, facilmente solúveis em água e a não utilização de adubo orgânico, cujas perdas de nutrientes é menor em presença de água). 
Este conjunto de fatores indicam que é provável que exista um manejo não ótimo da água o que se traduz em um desperdício de energia e da própria água (que é um bem escasso e severamente controlado), desperdícios que provocam a perda de fertilizantes, lavados pelo excesso da água, que percola nas camadas inferiores do solo, em lugares não mais acessíveis ao cultivo, vindo ao mesmo tempo a contaminar o lençol freático.

A quantificação deste fenômeno é difícil, como indicado, sem medições de campo. É difícil, unicamente a partir destes dados, avançar com propostas de medidas específicas; não restam porém dúvidas que o problema merece ser estudado mais a fundo e que é de interesse da concessionária elaborar parâmetros mais confiáveis sobre o tópico. Esta atividade da empresa elétrica pode ser facilitada, pelo fato de que a difusão dos sistemas de irrigação está concentrada em poucas empresas multinacionais, as quais possuem no exterior uma profunda experiência. Adequados contatos com as empresas matriz poderão facilitar a instalação de sistemas mais avançados e a realização de cursos de treinamento para os operadores. Ocorre notar que neste caso, a conservação de energia se daria sem necessidade de investimentos, unicamente com uma maior capacitação do pessoal técnico de projeto e de operação.

\section{Otimização do uso de energia.}

Independente da quantidade de energia utilizada, a distribuição de consumo no tempo (fator de carga das instalações) é uma variável importante para a concessionária e indiretamente para o consumidor. O uso de instalações super-dimensionadas, operando por uma curta duração, obriga a construção de linhas de distribuição sub utilizadas, com uma conseqüente sub utilização dos investimentos. 
A atual tarifa de baixa e média tensão do Equador, é de tipo binomial, mas quando a concessionária não dispõe de medidores de demanda, permite o faturamento da demanda na base da soma de todas as potências instaladas do consumidor. Esta norma evidentemente não incentiva a otimização do uso de energia por parte do consumidor, o qual independente do modo de operação, acaba pagando a mesma tarifa. A nova proposta tarifária emitida pelo INECEL DECTA (1992), permite uma cobrança mais justo pelo consumo da energia (como foi explicado no capítulo 4), por outro lado a maioria das agroindústrias encontram-se em faixas de consumo nas quais é conveniente a instalação de medidores de demanda.

Com a instalação de medidores de demanda, e com uma tarifa por demanda fixada em 2.31 US\$/kW, automaticamente o consumidor tenderá a otimizar suas instalações. Assim, os erros de super-dimensionamento das instalações tenderão a ser corrigidas, favorecendo desta forma um consumo mais uniforme da energia elétrica, e inclusive um melhor desempenho agronômico da água

\subsubsection{Câmaras de refrigeração}

Após o processo agronômico, a etapa de conservação das flores é de vital importância, assim como o choque térmico ao qual são submetidas as flores com a refrigeração que garante o florescimento. A refrigeração das flores permite prolongar o período de vida por mais de duas semanas, para que elas possam suportar o transporte e cheguem nas melhores condições de frescor e aparência ao mercado. 
Nas visitas realizadas, encontrou-se uma diversidade de critérios na concepção dos projetos, não há uniformidade do projeto entre agroindústrias. Sendo informados que a quantidade de flores armazenadas diariamente não lotam o volume das câmaras. Além disso o tempo de permanência das caixas dentro da câmara de refrigeração é relativamente curto, estando ao critério da agro indústria; para algumas, duas horas pode ser o tempo mínimo, enquanto que para outras o tempo mínimo é 24 horas.

As Tabelas D.5; D.14; D.21 e D.31, mostam o volume por hectare e os consumos de energia por hectare, para todos os tipos de cultivo e nas diferentes agroindústrias. O consumo registrado entre as diferentes culturas e as diferentes agroindústrias é muito ampla. Por exemplo o consumo de energia nas agroindústrias de várias culturas apresenta uma média de $901 \mathrm{kWh} / \mathrm{mês} / \mathrm{ha}$ e se registra um desvio muito alto de $607 \mathrm{kWh} / \mathrm{mês} / \mathrm{ha}$. Este fato deve-se aos diferentes critérios de construção das câmaras, tanto as dimensões e materiais de construção quanto ao dimensionamento das unidades de refrigeração. Em referência ao volume, para o grupo de agroindústrias que apresentam várias culturas, as Tabelas mostram uma média de $45 \mathrm{~m}^{3} / \mathrm{ha}$ com um desvio de 18 $\mathrm{m}^{3} / \mathrm{ha}$.

\section{Otimização da construção das câmaras}

Uma proposta de otimização da construção das câmaras é a realização de câmaras modulares, pois esta forma de construção permite pelo menos 3 maneiras de economia.

a.- Determinado o projeto global ele pode ser realizado por etapas com adição de novas unidades, já previstas. O projeto poderia ser único para todas as 
agroindústrias, o que facilitaria a execução das câmaras a nível semi industrial com uma conseqüente redução dos custos.

b.- Possibilidade de operação depende do regime de sazonalidade do mercado. Provavelmente o dimensionamento ideal é a divisão do espaço em 3 áreas sendo uma área a superfície para operar nos períodos de baixa atividade, e o total necessário nas condições pico.

c.- Maior segurança em caso de quebra de um equipamento, com a possibilidade de continuar operando, apesar de forma precária, com as demais câmaras.

\section{Otimização no consumo de energia.}

Como existe uma forte sazonalidade e as agroindústrias tendem a realizar as instalações em função de uma previsão de crescimento a otimização das instalações fixas pode ser obtida atraves da modulação. Por exemplo; supondo que a câmara é construída de maneira modular, com 3 unidades: Cada módulo consome uma energia de $400 \mathrm{kWh} / \mathrm{mês} / \mathrm{ha}$. Durante o período de máxima produção que são 3 meses, o consumo de energia será de $1.200 \mathrm{kWh} / \mathrm{mês} / \mathrm{ha}$, portanto nos 3 meses o consumo é $3.600 \mathrm{kWh} / \mathrm{mês} / \mathrm{ha}$. Nos 9 meses restantes a câmara não é utilizada em sua plena capacidade, portanto o consumo de energia de toda a câmara é de $800 \mathrm{kWh} / \mathrm{mês} / \mathrm{ha}$ (funcionado os 2 módulos com baixa carga térmica), obtendo-se o consumo correspondente aos 9 meses de 7.200 kWh/ha. Nestas condições de funcionamento da câmara o consumo anual é $10.800 \mathrm{kWh} / a n$ o/ha. Sem a operação modular e sazonal: nos três meses de maior produção de flores, o consumo de energia será de $3.600 \mathrm{kWh} / \mathrm{ha}$ e durante os 9 meses restantes o funcionamento também é de toda a câmara, portanto o consumo poderia alcançar $10.800 \mathrm{kWh} / \mathrm{ha}$. Nesta condição de funcionamento o 
consumo de energia ao ano será da ordem de $14.400 \mathrm{kWh} / \mathrm{ano} / \mathrm{ha}$.

No exemplo hipotético ao comparar, os dois resultados, que para o caso de construção não modular é de 14.400 kWh/ano/ha, e para o caso da construção modular é $10.800 \mathrm{kWh} / \mathrm{ano} / \mathrm{ha}$, pode-se observar que o funcionamento da câmara de refrigeração por módulos permite uma apreciável economia de energia.

Do exemplo anterior não pode generalizar -se que a economia de energia está nessa ordem dos resultados. Para ter uma avaliação real das condições de funcionamento das câmaras é indispensável realizar medições de temperatura, pressão e relacionar com o consumo de energia. Sendo recomendável colocar um mínimo de instrumental, dentro da câmara e no grupo frigorifico, para poder avaliar as perdas térmicas que se traduz em perdas de energia elétrica.

Outra medida de otimização de energia é estabelecer regimes de manutenção. Os equipamentos de refrigeração são estremamente sensíveis a condições de conservação e limpeza de seus componentes, especialmente do evaporado e do condensador. Deveriam ser montadas rotinas de inspeção periódica dos equipamentos, com a indicação dos cuidados a serem tomados com os diferentes componentes.

\subsubsection{Sistemas de iluminação:}

Naquelas agroindústrias que cultivam espécies de flores sujeitas a fotoperiodismo a iluminação estimula ou inibe o florescimento destas espécies, portanto os cultivos precisam de um maior número de horas de luz por dia, sendo iluminados depois das 18 horas até as 6 horas da manhã. A iluminação do cultivo, representa uma parcela muito alta do consumo de energia para as agroindústrias que cultivam estas espécies. No caso do cultivo da gipsófila, além de utilizar a 
iluminação no cultivo, se utiliza para uma etapa complementar de abertura das flores que realiza-se numa sala fechada denominada a "sala de abertura das flores".

Os projetos de iluminação são realizados na base do critério de obter uma iluminância média uniforme em todos os canteiros de 130 lux (12 foot candle $)^{2}$, que é a exigência agronômica para induzir as plantas ao florescimento. Porém segundo CANHAM (1966) é suficiente uma iluminância de 54 até 110 lx para estimular as plantas.

Dependendo da fonte de luz utilizada, sejam lâmpadas incandescentes ou a vapor de sódio, vai associada a maneira de operação das lâmpadas, portanto a demanda e o consumo de energia. Os critérios do projeto de iluminação com lâmpadas incandescentes ou a vapor de sódio, são analisados a seguir:

1- O projeto com lâmpadas incandescentes.- O consumo de energia, depende dos períodos estabelecidos de liga/desliga nos ciclos de operação das lâmpadas. As Tabelas D.11 e D.27 mostram para as agroindústrias que utilizam lâmpadas incandescentes, utilizam uma potência instalada por hectare em média de 92 $\mathrm{kW} / \mathrm{ha}$, com um baixo desvio de $12 \mathrm{~kW} / \mathrm{ha}$; esta similaridade na potência instalada se deve aos critérios de execução do projeto, que são uniformes entre as agroindústrias. Porém a média dos consumos é de $6.180 \mathrm{kWh} / \mathrm{mês} / \mathrm{ha}$, com um considerável desvio de $1.976 \mathrm{kWh} /$ mês/ha, este desvio é explicável em função da escolha dos tempos de operação de cada cíclo que são diferentes, para cada agroindústria.

2Dado obtido das informações da pesquisa de campo. 
2- No caso de utilização de lâmpadas a vapor de sódio, o funcionamento das lâmpadas é de maneira contínua, todas são ligadas por vez, durante 4 horas. $\mathrm{Na}$ Tabela D.11 mostra a potência instalada é 16,36 kW/ha e o consumo de energia de $1.964 \mathrm{kWh} / \mathrm{mês} / \mathrm{ha}$.

As Tabelas D.11 e D.27 mostram os dados de demanda e energia, ao iluminar os cultivos com lâmpadas incandescentes e a vapor de sódio. É importante notar a diferença tanto na demanda quanto no consumo, que tem uma relação de 1 a 5.

\section{Otimização da energia no cultivo}

Foram realizados os cálculos do projeto de iluminação visando obter uma iluminância uniforme de 130 lux. Para determinar a quantidade de lâmpadas, que guarde similaridade com os dados da pesquisa, foi necessário assumir alguns parámetros do projeto, tais como: o fator de eficiência dos materiais de construção da estufa e das luminárias, em torno de $80 \%$, situação que não pode ser aceita, porque na realidade a eficiência das luminárias e do local são baixas, já que são materiais pouco refletivos. Desta maneira foi comprovada que a iluminância colocada como uma exigência fixa, não é obtida a campo. Os cálculos mostram que as condições de operação são com uma iluminância da ordem de 90 até 110 lux.

A concepção do projeto é bastante bom. Porém como medidas de racionalização de energia se propõe duas alternativas:

1.- Otimizar os intervalos de escuridão no ciclos de operação de liga/desliga das lâmpadas. 
Para o caso de iluminação com lâmpadas incandescentes, se observa que o fator de utilização ultrapassa $70 \%$ por hora, portanto os períodos de escuridão que se obtém devido aos intervalos nos quais todas as lâmpadas estão desligadas, antes de ligar o novo grupo de lâmpadas, de acordo aos ciclos estabelecidos são de 7 ou 5 minutos. Estes períodos curtos de escuridão que ocorre ao desligar o grupo de lâmpadas até ligar o seguinte grupo, representa $30 \%$ (18 minutos durante uma hora), durante o qual não há consumo de energia.

Para otimizar o consumo de energia se poderiam prolongar os períodos de escuridão a $40 \%$, de maneira que em cada hora se tem 24 minutos sem consumo de energia. Passar de $30 \%$ a $40 \%$ de escuridão, representa 6 minutos em cada hora, esta modalidade estendendo para 10 horas de funcionamento dos ciclos e uma demanda média de $92 \mathrm{~kW} / \mathrm{h} a$, se obtém uma economia de energia de 33.580 kWh/ano/ha (aproximadamente $2.700 \mathrm{kWh} / \mathrm{mês} / \mathrm{ha}$ ).

2.- Implementar os novos projetos com lâmpadas fabricadas para propósitos agronômicos, como são: lâmpadas a vapor de sódio T-AGRO de 400 W e as lâmpadas incandescentes "flower power", que tem superfície refletora em seu interior 3 .

Com a mesma metodologia com a qual foi calculado o projeto com as lâmpadas incandescentes, foi calculado para as lâmpadas "flower power", de sódio $400 \mathrm{~W}$, de sódio $250 \mathrm{~W}$ e a SON-T AGRO 400W. A demanda e consumo de energia que se obteve com estas lâmpadas para iluminar os $7.000 \mathrm{~m}^{2}$ é menor com respeito à demanda e energia que se obteve com as lâmpadas incandescentes convencionais; porém devido a seu alto custo de investimento é industriais, para iluminação dos cultivos. 
conveniente realizar a análise econômica destas alternativas de iluminação.

\section{Otimização da utilização de lâmpadas incandescentes e a vapor de}

\section{sódio na sala de abertura.}

As condições de projeto das salas de abertura das flores, são precárias e construídas com materiais, como papelão, plástico,"tijolo", que não favorecem nenhuma das exigências básicas que a sala requer, que são: manter uma elevada temperatura e um alto nível de iluminância.

Quando as salas são iluminadas com lâmpadas incandescentes, se registra uma alta perda do fluxo luminoso, as lâmpadas são instaladas sem luminária e o material com que é construído o teto da sala não permite a reflexão da luz. Devido à proximidade das lâmpadas com o teto é recomendável que o teto seja realizado em alvenaria e pintado com pintura refletiva.

No caso de iluminar com lâmpadas a vapor de sódio, a sala é aquecida com resistências elétricas, as quais são colocadas nas paredes da sala. A utilização destas resistências representam um alto consumo de energia. Considera-se conveniente propor duas soluções:

Primeira, seria possível a construção de salas para abertura das flores com maior índice de isolamento térmico, permitindo um aumento da temperatura com uma menor potência. Se as salas fossem construídas com forro isolado, a quantidade de calor proporcionada pelas lâmpadas a vapor de sódio seria suficiente para o aquecimento.

Uma segunda opção seria realizar o aquecimento do ambiente utilizando estufas a gás liquefeito de petróleo (GLP). Esta solução teria a vantagem adicional de gerar $\mathrm{CO}_{2}$. o qual representa um nutriente para as plantas, acelerando os processos fisiológicos. 


\subsubsection{Sublimadores}

Nas Tabelas D.3 e D.29 mostram os consumos de energia correspondentes à utilização dos sublimadores. 0 mesmo modelo de sublimador é difundido em todas as agroindústrias. Estes aparelhos são ligados diariamente 7 horas a partir das 18 horas.

No caso das agroindústrias de cultivo exclusivo de rosas o consumo de energia dos sublimadores é representativo, está na ordem de $1.077 \mathrm{kWh} / \mathrm{mês} / \mathrm{ha}$, sendo quase $040 \%$ do total da energia da agro indústria.

São aparelhos que não apresentam um tecnologia desenvolvida que otimize o consumo de energia. Não obstante, para melhor utilização destes aparelhos se propõe as seguintes medidas na operação:

1.- Automatizar o liga/desliga, a fim de que a operação dos equipamentos seja realizada após as 22 horas, conseguindo desta maneira que o funcionamento se realize fora das horas pico, sendo desligados antes da chegada dos funcionários a suas tarefas cotidianas.

2.- Estudar sistemas que garantem uma distribuição mais uniforme do sublimador do enxofre. Uma solução seria ter os sublimadores mais fechados,

\subsection{CONCLUSÕES}

As medidas de racionalização de energia foram propostas na base de conseguir uma melhor utilização da energia elétrica, sem comprometer os níveis de produtividade das agroindústrias.

Para emitir os critérios de medidas de racionalização, foram analisados os projetos, o de dimensionamento dos equipamentos a ser instalados e os modos de utilização. 


\section{AVALIAÇÃO ECONÔMICA}

No capítulo anterior, foram apresentadas cinco alternativas para iluminação do cultivo de flores, cada qual cumprendo com as exigências agronômicas que estimulam as respostas de florescimento das plantas. Como as alternativas satisfazem tecnicamente o fim ao qual são destinadas é pertinente realizar a avaliação econômica, a fim de decidir qual é o projeto de iluminação mais econômico.

\subsection{ANÁLISE FINANCEIRA DA TROCA DE LÂMPADAS POR HECTARE DE CULTIVO DE FLORES.}

Para avaliar as diferentes alternativas de iluminação, tais como: lâmpadas incandescentes convencionais, lâmpadas incandescentes "power flower", lâmpadas a vapor de sódio 400 W, lâmpadas a vapor de sódio 250 W e lâmpadas a vapor de sódio "SONT-AGRO" 400 W, foi utilizada a informação da pesquisa de campo respeito a potência, espaçamento (de instalação) e tempo de uso, diário.

As lâmpadas incandescentes são colocadas no cultivo a $3 \mathrm{~m}$. de distância entre si, desta maneira cada lâmpada cobre uma área de $9 \mathrm{~m}^{2}$. Para iluminar um hectare $^{1}$ de cultivo precisa-se de 759 lâmpadas, portanto se obtém uma demanda de $150 \mathrm{~kW} / \mathrm{ha}$ e uma energia média mensal de $9.235 \mathrm{kWh} / \mathrm{mês} / \mathrm{ha}$.

No caso de lâmpadas incandescentes espelhadas "power flower" (suas caraterísticas encontram-se no Anexo A), foram escolhidas sob o critério que são lâmpadas de uso exclusivo par fins agrícolas. A presença da superfície refletora permite uma melhor eficiência do fluxo luminoso. 
Para o dimensionamento do projeto se fez sob o critério de conseguir uma iluminância de 110 até 130 lux. Para obter um nível uniforme de 100 até 130 lux, elas devem ser colocadas a 2,7 m de distância entre si, portanto a quantidade total de lâmpadas por hectare é 962. Esta quantidade de lâmpadas representa uma demanda de $77 \mathrm{~kW} / \mathrm{ha}$ e um consumo de energia mensal de 4.682 kWh/mês/ha.

Os projetos com lâmpadas a vapor de sódio foram calculados de maneira a se obter um nível de iluminância de 130 lux, como mostram os dados da pesquisa. Desta forma se obteve o seguinte espaçamento: as lâmpadas a vapor de sódio $400 \mathrm{~W}$, se encontram a $12 \mathrm{~m}$ de distância entre elas, as lâmpadas a vapor de sódio $250 \mathrm{~W}$ a 9 m equidistantes entre si e as lâmpadas SONT-AGRO $400 \mathrm{~W}$ são espaçadas a $14 \mathrm{~m}$.

Como no caso das lâmpadas incandescentes, a área útil estimada é 7.000 $\mathrm{m}^{2}$ por hectare. No projeto foi calculado a quantidade de lâmpadas a vapor de sódio, estimando como fator de eficiência da luminária em torno de $65 \%$.

Uma vez determinada a quantidade de lâmpadas para cada alternativa foi elaborada a Tabela 7.1 anotando as caraterísticas de cada uma delas, portanto a potência nominal das lâmpadas, a demanda por hectare, a vida útil, as horas de uso (que mais adiante serão explicadas) e finalmente o consumo de energia anual e mensal.

As horas de uso das lâmpadas incandescentes foram calculadas considerando que a potência coincidente é a terceira parte da potência instalada, o que significa que cada lâmpada funciona 20 minutos em cada hora. Além disso foram levados em conta os ciclos de operação recomendados neste estudo de $60 \%$ de luz (ligada a lâmpada) e $40 \%$ de escuridão (desligada a lâmpada), sendo o tempo de funcionamento da lâmpada não de 20 minutos, mas de 12 minutos. De 
acordo com as informações da pesquisa, diariamente o sistema de iluminação trabalha uma média de 10 horas, portanto cada lâmpada funciona 2 horas por dia, desta maneira, nos 365 dias do ano funcionará 730 horas.

Nos casos das lâmpadas a vapor de sódio, segundo a informação da pesquisa elas não cumprem ciclos alternos de funcionamento, são ligadas 4 horas diárias de maneira contínua, sendo no ano o funcionamento de 1.460 horas.

Tabela 7.1: CARATERÍSTICAS DAS ALTERNATIVAS PARA ILUMINAÇÃO DOS CULTIVOS

\begin{tabular}{|c|c|c|c|c|c|c|c|}
\hline ALTERNATIVAS & QUAN & $\begin{array}{l}\text { POT } \\
\text { NOM } \\
\text { W }\end{array}$ & $\begin{array}{l}\text { DEM } \\
\text { MAXI } \\
\text { kW/ha }\end{array}$ & $\begin{array}{l}\text { VIDA } \\
\text { ÚTIL } \\
\text { horas }\end{array}$ & $\begin{array}{l}\text { HOR } \\
\text { USO } \\
\text { h/ano }\end{array}$ & $\begin{array}{l}\text { ENERG } \\
\text { ANO } \\
\text { kWh/ha }\end{array}$ & $\begin{array}{l}\text { ENERG } \\
\text { MÊS } \\
\text { kWh/ha }\end{array}$ \\
\hline Incandescente conven A & 759 & 200 & 152 & 800 & 730 & 110.814 & 9.235 \\
\hline Incandescente espelha B & 962 & 80 & 77 & 800 & 730 & 56.181 & 4.682 \\
\hline Sódio $400 \mathrm{~W}$ & 42 & 440 & 18 & 12.000 & 1.460 & 26.981 & 2.248 \\
\hline Sódio $250 \mathrm{~W}$ & 78 & 275 & 21 & 12.000 & 1.460 & 31.317 & 2.610 \\
\hline SONT-AGRO $400 \mathrm{~W} \quad \mathrm{E}$ & 38 & 435 & 17 & 12.000 & 1.460 & 24.134 & 2.011 \\
\hline
\end{tabular}

Observando os dados resumidos na Tabela 7.1, a demanda das lâmpadas a vapor de sódio é muito baixa ( 7 vezes menor) que a demanda das lâmpadas incandescentes convencionais.

A relação do consumo de energia das lâmpadas a vapor de sódio com o das lâmpadas incandescentes convencionais é de $25 \%$ porque de fato o número de horas de funcionamento das lâmpadas a vapor de sódio é quase o dobro.

Para realizar a avaliação econômica das alternativas é conveniente calcular o custo do investimento e o custo da energia das diferentes alternativas. Além dos custos das lâmpadas, o cálculo deve levar em conta o custo da alimentação elétrica, porque os equipamentos para a instalação das lâmpadas a vapor de sódio é diferente em relação à rede para as lâmpadas incandescentes. 
Portanto o investimento em transformador de distribuição, cabos, controle da automatização dos ciclos de operação influência no custo total da alternativa.

Para calcular o custo da energia economizada (custo de energia economizada CEE), é necessário calcular o custo efetivo do investimento por unidade de energia economizada ao ano.

A Tabela 7.2 mostra os custos de investimento de cada elemento utilizado na implementação das alternativas.

Tabela 7.2: CUSTOS DO INVESTIMENTO DE LÂMPADAS, REDE E ACESSÓRIOS

\begin{tabular}{|l|r|r|r|r|r|}
\hline ACESSÓRIOS & INCAND A & INCAND B & SÓD400 W & SÓD250 W & SONT400W \\
\hline LÂMPADA US $\$ / \mathrm{u}$ & 1,20 & 3,75 & 32,50 & 26,30 & 37,60 \\
LUMINÁRIA US $\$ / \mathrm{u}$ & 0,60 & 0,00 & 87,00 & 87,00 & 197,00 \\
REATOR US $\$ / \mathrm{u}$ & 0,00 & 0,00 & 16,50 & 16,50 & 19,40 \\
TRANSFOR US $\$ / \mathrm{u}$ & $2.250,00$ & $1.125,00$ & 750,00 & 750,00 & 750,00 \\
REDE US $\$ \mathrm{ha}$ & $2.459,00$ & $2.459,00$ & $1.496,00$ & $1.496,00$ & $1.496,00$ \\
CONTROLE US $\$ / \mathrm{ha}$ & 810,00 & 810,00 & 0,00 & 0,00 & 0,00 \\
INVESTIMENT US $\$ / \mathrm{ha}$ & $6.885,20$ & $8.001,50$ & $7.958,00$ & $12.370,40$ & $11.898,00$ \\
\hline
\end{tabular}

Os preços foram pesquisados no mercado equatoriano. (1 US $\$=2.260$ SUCRES)

Em todos os custos está incluído o imposto ao valor agregado (IVA) de 10\%.

A Tabela 7.2 mostra que apesar do maior custo unitário das lâmpadas a vapor de sódio de $400 \mathrm{~W}$, os totais mostram para os dois tipos de lâmpadas um investimento similar.

Esta situação é devido a que nas lâmpadas incandescentes o custo do controle, transformador e da rede de distribuição, aumenta o custo total da alternativa.

Como cada elemento apresenta diferente vida útil, conforme mostra a Tabela 7.3 , foram calculados os valores anualizados destes elementos para uma 
taxa de desconto de $15 \%$. Foi escolhido o $15 \%$ como taxa de desconto, porque normalmente os investidores privados usam uma taxa de desconto alta que seja atrativa para realizar o investimento. Desta maneira foi utilizado um valor maior ao que a concessionária utiliza para as análises de alternativas de geração, que está na faixa de 7 até $12 \%$.

Aliás o resultado de sensibilidade, mostrados na Figura 7.1, indica que as condições das alternativas são insensíveis à variação da taxa de desconto.

Tabela 7.3: TEMPO DE OPERAÇÃO DOS ELEMENTOS UTILIZADOS NA INSTALAÇÃO DO SISTEMA DE ILUMINAÇÃO

\begin{tabular}{|l|r|}
\hline MATERIAIS UTILIZADOS PARA A INSTALAÇÃO DAS & $\begin{array}{l}\text { TEMPO DE } \\
\text { OPERAÇÃO } \\
\text { ALTERNATIVAS }\end{array}$ \\
\hline Lâmpadas incandescentes convencionais, e power flower (1) & 1,09 \\
Lâmpadas a vapor de sódio 400 W; 250 W; SONT 400 W(1) & 8,21 \\
Luminária para incandescente (1) & 3 \\
Luminária para sódio 250 W; 400 W (2) & 6 \\
Luminária para SONT-AGRO 400W (2) & 8 \\
Reator sódio 250W; 400W; SONT (2) & 8 \\
Rede interna (3) & 10 \\
Transformadores 75; 37,5 25 kVA (4) & 15 \\
Controle para as lâmpadas incandescentes (2) & 2 \\
\hline
\end{tabular}

(1) O tempo de operação destes equipamentos foi calculado na base das informações da pesquisa.

(2) O tempo de operação destes elementos foi determinado na base das informações do fabricante.

(3) A rede interna foi estimado como tempo de operação 10 anos, porque os condutores estão sujeitos a uma contaminação química dos agro tóxicos.

(4) Foi estimado como tempo de operação 15 anos, na base da estimação que faz a concessionária.

Para poder comparar o custo implementação de cada alternativa, foi calculado o custo do ciclo de vida anualizado de todos os componentes de cada alternativa, (custo de ciclo de vida anualizado CCVA). 
Prévio ao cálculo de CEE e CCVA, se fez uma análise de sensibilidade do custo anualizado do investimento de cada alternativa ao variar as taxas de desconto de $7 \%$ até $25 \%$, como mostra a Figura 7.1

Para calcular o custo de energia, foram utilizados os dados de tarifa vigente no Equador de 70,37 US $\$ / \mathrm{kWh}$ e o custo de demanda de 2,31 US $\$ / \mathrm{kW}$ instalado (estes valores foram apresentados no capítulo 4). Os cálculos do custo de consumo de energia e demanda foram realizados com a tarifa industrial com demanda (ID),

Figura 7.1

\section{CUSTO ANUAL DAS ALTERNATIVAS}

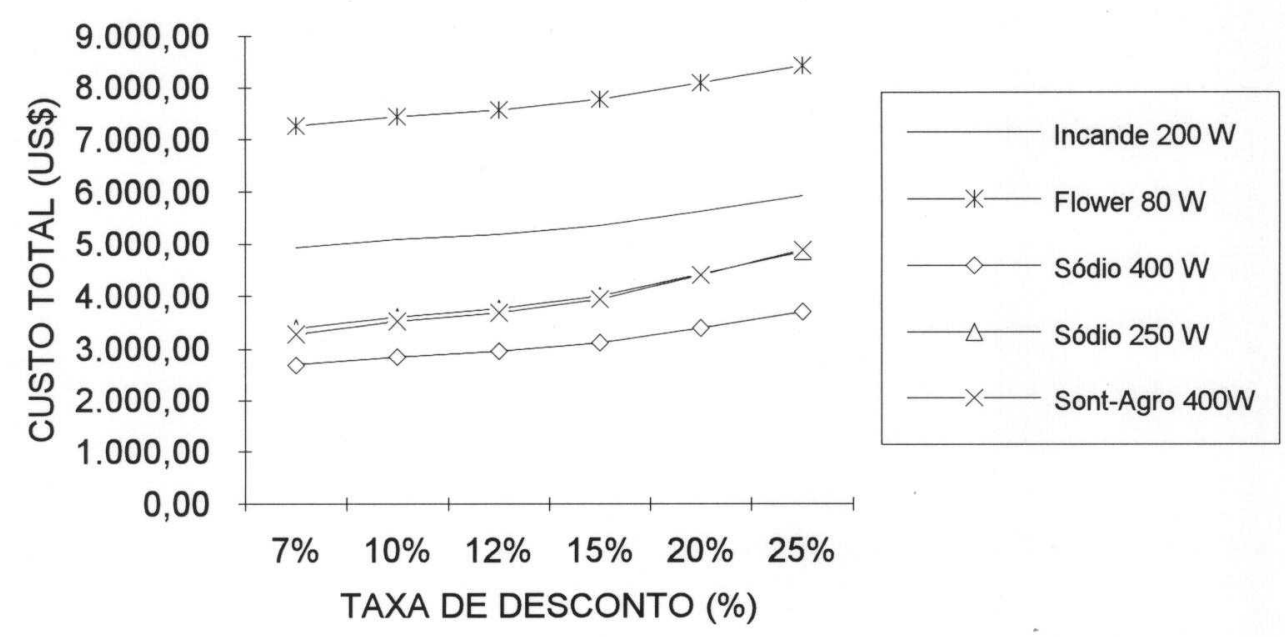

A Tabela 7.4 apresenta, o custo anualizado do investimento a taxa de $15 \%$, como a soma dos valores anualizados das lâmpadas e acessórios, levando em conta o tempo de operação destes elementos. A Tabela 7.4 também apresenta o custo de manutenção anual, custo anual de energia e os cálculos de CCVA e CEE. 
Tabela 7.4: $\quad$ CUSTO ANUALIZADO DO INVESTIMENTO CCVA E CUSTO DE ENERGIA ECONOMIZADA CEE

\begin{tabular}{|c|c|c|c|c|c|}
\hline ALTERNATIVA & $\begin{array}{l}\text { INVESTIMEN } \\
\text { ANUALIZAD } \\
\text { US\$ }\end{array}$ & $\begin{array}{c}\text { MANUTE } \\
\text { ANUAL } \\
\text { US\$ }\end{array}$ & $\begin{array}{c}\text { CUSTOIANO } \\
\text { ENERGIA } \\
\text { US\$ }\end{array}$ & CCVA & US\$/kWh \\
\hline Incandescente $\mathrm{A}$ & $2.597,33$ & $2.760,00$ & $14.527,11$ & $19.884,44$ & \\
\hline Incandescente B & $5.004,00$ & $2.760,00$ & $7.365,00$ & $15.129,00$ & 0,044 \\
\hline Sódio 400 W C & $1.846,28$ & $1.380,00$ & $2.917,19$ & $6.143,47$ & $-0,025$ \\
\hline Sódio 250 W D & $2.824,71$ & $1.380,00$ & $3.400,45$ & $7.605,16$ & $-0,014$ \\
\hline AGRO-400W E & $2.563,10$ & $1.380,00$ & $2.620,49$ & $6.563,59$ & $-0,016$ \\
\hline
\end{tabular}

Ao comparar os resultados obtidos das figuras de mérito, a melhor alternativa para iluminar, com custos baixos está representada pelas lâmpadas a vapor de sódio de $400 \mathrm{~W}$, que registra o menor custo de investimento, o menor custo de manutenção, e o menor custo de energia.

Por outro lado todas as alternativas, executando as lâmpadas "power flower", comparada com as lâmpadas incandescentes convencionais, são interessantes, tanto do ponto de vista do investimento quanto do consumo de energia. Porém a alternativa das lâmpadas de sódio $400 \mathrm{~W}$ é preferível, sendo também atrativa a alternativa das lâmpadas SONT 400W, elas apresentam maior eficiência, e seu objetivo de aplicação é para o setor agrícola.

Por outro lado o CEE, para as lâmpadas sódio $400 \mathrm{~W}$ é de 0,025 US\$/kWh, por tanto $1 / 3$ do custo da energia fornecida pela concessionária, conseqüentemente é um investimento vantajoso para as agro indústrias. Pudendo, decidir as instalações do sistema de iluminação com lâmpadas de sódio $400 \mathrm{~W}$. 


\subsection{CONCLUSÕES}

Como medidas de racionalização de energia para o sistema de iluminação se propõe a mudança das lâmpadas incandescentes para lâmpadas a vapor a sódio a alta pressão de $400 \mathrm{~W}$, sendo esta recomendação avaliada na base do requerimento agronômico (técnico) das plantas e da avaliação econômica do projeto.

No caso de manter as lâmpadas incandescentes a proposta é otimizar os períodos de liga e desliga, numa relação de $60 \%$ do período de luz e $40 \%$ de escuridão. Para o qual é necessário modificar os ajustes nos temporizadores do sistema de controle

Se, a agro indústria decide a utilização das lâmpadas a vapor de sódio, é conveniente instala-las a alturas superiores a $9 \mathrm{~m}$, portanto sua aplicação é interessante em cultivos fora de estufa. A instalação das lâmpadas à altura mencionada permite iluminar uma maior área do cultivo, portanto o sistema de iluminação apresenta maior eficiência. 


\section{CONCLUSÕES E RECOMENDAÇÕES}

Para cada uso final foram propostas medidas específicas de racionalização de energia. Maior ênfases se fez no uso da iluminação, sendo apresentadas quatro alternativas, que foram avaliadas técnica e economicamente.

Para os outros usos, como: câmara de refrigeração, irrigação e sublimadores, não foi quantificado o potencial de demanda e energia conservada, porque não se dispõe dos dados para realizar a avaliação correspondente. Porém foram expostos alguns critérios como medidas de racionalização de energia baseados na pesquisa de campo.

Como resultado principal da pesquisa foi possível demostrar que o sistema atualmente utilizado para induzir o florescimento de plantas sujeitas a fotoperiodismo (sejam elas plantas de dia longo ou de dia curto) utilizando lâmpadas incandescentes é menos eficiente, econômica e energeticamente, que o uso de lâmpadas a vapor de sódio.

Utilizando lâmpadas a vapor de sódio, é possível economizar $90 \%$ da potência instalada e $80 \%$ do consumo de energia. O fato mais importante foi demostrar que, apesar do maior custo do investimento em lâmpadas a vapor de sódio, quando é levado em conta o custo adicional da alimentação elétrica (transformadores de distribuição, cabos e controles) o custo do investimento é similar nas duas opções, portanto, não existe restrição à difusão desta tecnologia.

No caso da irrigação, comparando os dados parametrizados nas diferentes empresas e nas diferentes culturas foi possível notar um elevado desvio de consumo, a média do consumo e da potência instalada são respectivamente de 
$586 \mathrm{kWh} / \mathrm{ha}$ e de $3 \mathrm{~kW} / \mathrm{ha}$, com um desvio de $557 \mathrm{kWh} / \mathrm{ha}$ e de 1,8 kW/ha.

É possível indicar que o amplo desvio depende, de um lado, das condições de projeto (posição da água em relação à área irrigada e as exigências dos cultivos), e do outro, depende em parte de um manejo inadequado dos sistemas de irrigação.

A impressão visual durante as visitas foi de que, na maioria das culturas se trabalha com excesso de água e não com deficiências. Este fato demostra que além do desperdício de energia para bombear a água, existem perdas de nutrientes no solo por percolação, portanto, poluição e perda da própria água.

Não foi possível avaliar o potencial de economia de energia pela ausência de dados específicos como: o nível de evapo-transpiração da região, altura mano métrica e as necessidade agronómicas das plantas.

Um estudo mais aprofundado do problema, com a instalação de sistemas de controle eletrônico poderia permitir reduções sensíveis destas perdas. O melhor controle no suprimento da água, se traduz em reduções significativas de energia. A racionalização do uso da água leva também um aumento do rendimento agronômico.

Porém, como medidas propostas para a utilização de energia se recomenda a instalação de sensores de umidade no solo, a fim de automatizar a necessidade de água fornecida.

Outra recomendação válida, é que o dimensionamento das bombas, sejam de baixa capacidade, de maneira que possam satisfazer o fornecimento de um volume de água em maiores períodos de tempo, melhorando assim o fator de carga deste uso. 
Outra proposta de racionalização de energia pode conseguir-se controlando a velocidade dos motores com reguladores de velocidade substituindo às válvulas volumétricas, utilizadas em todas as agro indústrias. Esta proposta é aplicável para os casos onde é preciso variar a vazão e o fornecimento de água se realiza em prolongados períodos.

Sendo o choque térmico um processo complementar para garantir o florescimento, é um uso básico de todas as agro indústrias. Aliás, o consumo de energia não é o mais representativo dentro de todo o setor de cultivo de flores. Porém o consumo de energia e a demanda de potência alcançam uma média de $938 \mathrm{kWh} / \mathrm{ha}$ e de $1,97 \mathrm{~kW} / \mathrm{h}$ a respectivamente, com um desvio de $444 \mathrm{kWh} / \mathrm{ha}$ e $1,66 \mathrm{~kW} / \mathrm{ha}$. A origem do grande desvio neste uso final é atribuído à falta de definição nas técnicas utilizadas. Os dados paramétricos mostram uma variação enorme nas variáveis de construção como o volume das câmaras, varia de 8 até $90 \mathrm{~m}^{3} / \mathrm{ha}$

As câmaras são construídas sem nenhum padrão, encontrando-se materiais e unidades de refrigeração numa ampla gama.

Com a relação das caraterísticas das câmaras, é factível recomendar duas medidas de otimização de energia, que são: que a construção seja de forma modular e outra medida estabelecer rotinas de manutenção das unidades de refrigeração.

Nas agro indústrias que cultivam gipsófila, as salas de abertura devem ser construidas de lado da câmara de refrigeração, para que o calor emitido pelo condensador seja aproveitado no aquecimento da sala. Desta maneira a sala pode ser iluminada com lâmpadas a vapor de sódio sem precisar das resistências que são colocadas para gerar calor na sala. 
Para obter uma otimização de energia na utilização dos sublimadores recomenda-se instalar temporizadores que automatizem os períodos de ligado nas horas da madrugada. Desta maneira seria deslocada a carga dos sublimadores que é representativa dentro do setor de flores e que coincide com as horas pico da concessionária.

O cálculo das mudanças nos sistemas de iluminação para induzir o florescimento representa um resultado positivo do estudo. O estudo poderá ampliar-se para os outros usos, quando se disponha dos dados específicos.

Por ser um setor pequeno em número de consumidores, existe uma boa probabilidade, que as propostas de medidas de racionalização de energia enunciadas anteriormente sejam acolhidas de maneira prática pelos floricultores.

Para que o estudo tenha uma consequência prática, ele será difundido nas Instituições diretamente relacionadas com o setor de floricultores, como são: "Asociación de floricultores del Ecuador", "Programa de Exportaciones Agrícolas No Tradicionales PROEXANT"

Devido ao dinâmico crescimento das agro indústrias é conveniente que através da concessionária se participe aos novos consumidores das possibilidades de racionalização em a instalação e operação dos equipamentos. 
ANEXOS 


\section{ANEXO A :}

CARACTERISTICAS DAS LÂMPADAS INCANDESCENTES POWER FLOWER E LÂMPADAS A VAPOR DE SÓDIO SONT-AGRO

\section{Tabela A.1:}

\section{CARACTERÍSTICAS DA LÂMPADA POWER FLOWER $80 \mathrm{~W}$}

\begin{tabular}{|l|l|}
\hline \multicolumn{2}{|l|}{ Características das lâmpadas power flower } \\
\hline Potência & $80 \mathrm{~W}$ \\
Tensão & $230 \mathrm{~V}$ \\
Vida útil & 1.000 horas \\
Intensidade luminosa & 300 candle \\
Ângulo & $80^{\circ}$ \\
Peso. & $45 \mathrm{gr}$ \\
Cap. & E27 \\
\hline
\end{tabular}

Fonte: PHILIPS Lighting Product information (1993)

Figura A.1: CURVAS DE INTENSIDADE LUMINOSA PARA A LÂMPADA POWER FLOWER $80 \mathrm{~W}$

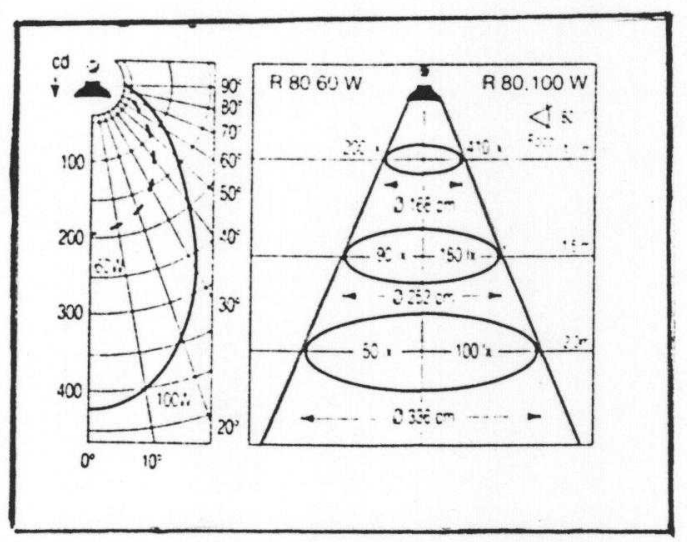

Fonte: PHILIPS Lighting Product information (1993) 


\section{Tabela A.2: CARACTERÍSTICAS DAS LÂMPADAS A VAPOR DE SÓDIO SONT-AGRO $400 \mathrm{~W}$}

\begin{tabular}{|l|c|}
\hline Fluxo medido & $52.000 \mathrm{Im}$ \\
Potência & $435 \mathrm{~W}$ \\
Fluxo radiante & $130 \mathrm{~W}$ \\
Eficiência de radiação & $300 \mathrm{~mW} / \mathrm{W}$ \\
Fator de conversão & $2,5 \mathrm{~mW} / \mathrm{lm}$ \\
Tensão mínima do ignitor & $2.800 \mathrm{~V}$ \\
Tensão mínima & $198 \mathrm{~V}$ \\
Máxima corrente de partida & $5,5 \mathrm{~A}$ \\
Mínima tensão para operação estável & $198 \mathrm{~V}$ \\
Corrente média & $4,13 \mathrm{~A}$ \\
Tensão média & $116 \mathrm{~V}$ \\
\hline
\end{tabular}

Fonte: PHILIPS Lighting Product information (1993) 


\section{ANEXO B:}

Figura B.1: DIVISÃO POLITICA DO TERRITÓRIO EQUATORIANO

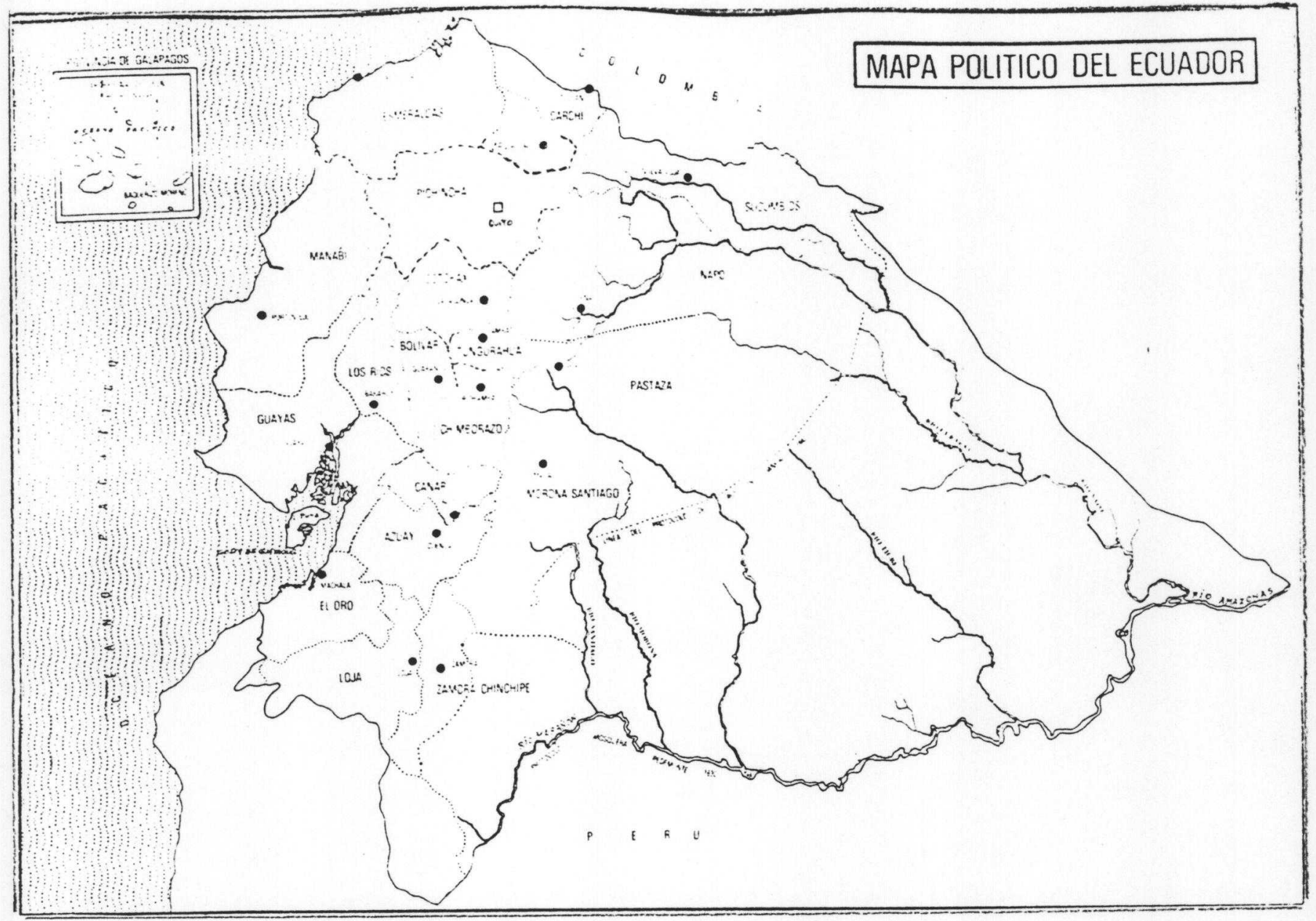


Figura B.2: ÁREA DE CONCESSÃO E DIAGRAMA DO SISTEMA DE SUBTRANSMISSÃO DA EMELNORTE

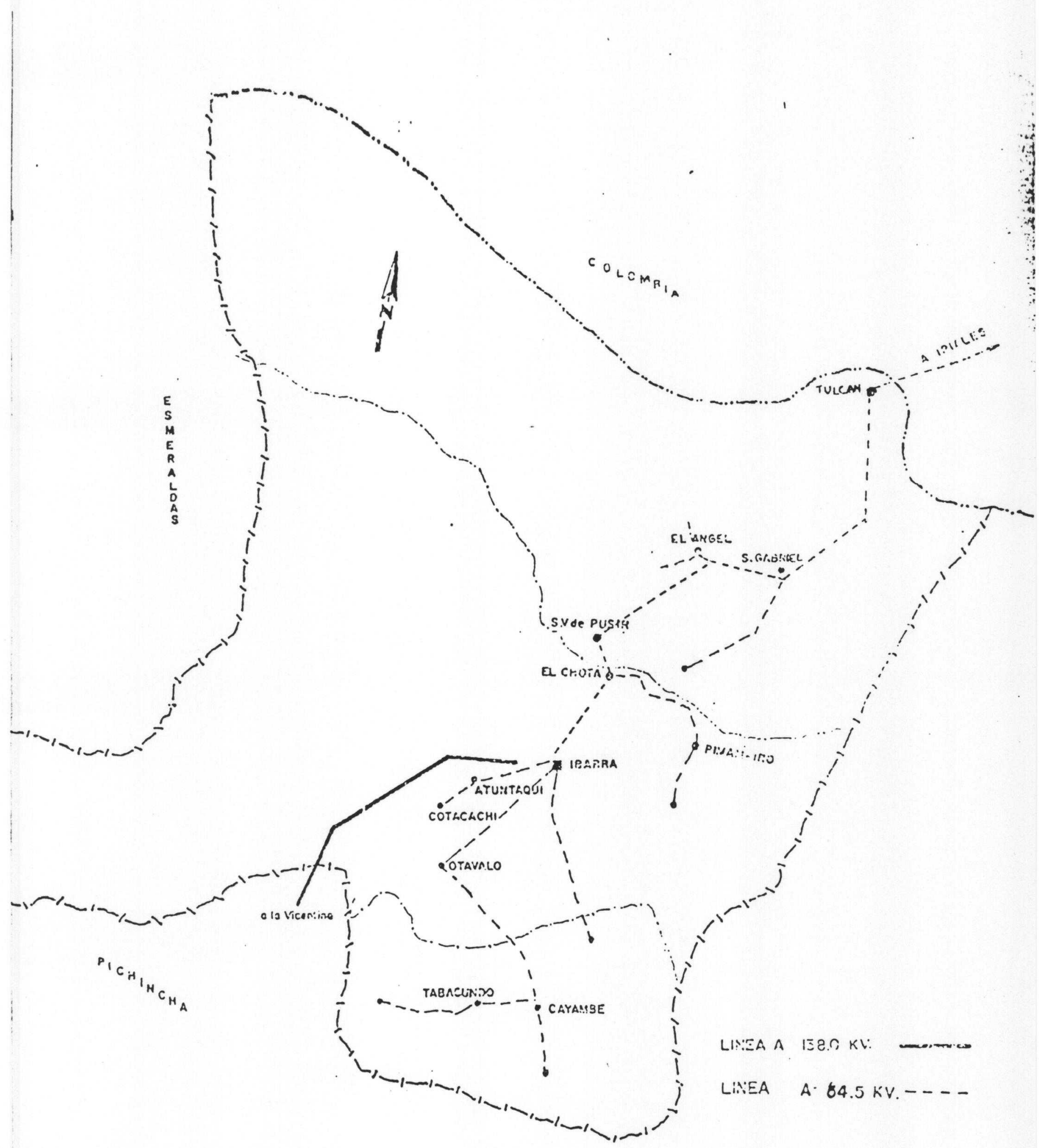




\section{ANEXO C}

\section{USOS FINAIS NAS AGROINDÚSTRIAS DE CULTIVO DE FLORES}

\section{INFORMACÕES GERAIS DA AGROINDÚSTRIA}

Nome da agroindústria

Endereço......

Data:

Consumo médio mensal (ano 1993):

Potência média instalada (ano 1993):

Tipo de cultivo: Área

Área.

O cultivo é dentro de estufa? SIM.........NÃO

Número de funcionários

\section{REDE DE DISTRIBUIÇÃO}

Evolução das instalações dos transformadores de distribuiçao. Cargas atingidas

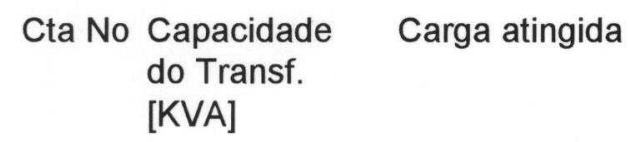

\section{EQUIPAMENTOS DE USOS FINAIS E CONSUMO DE ENERGIA}

\section{ILUMINAÇÃO}

Lâmpadas incandescentes:

No cultivo:

finalidade de uso

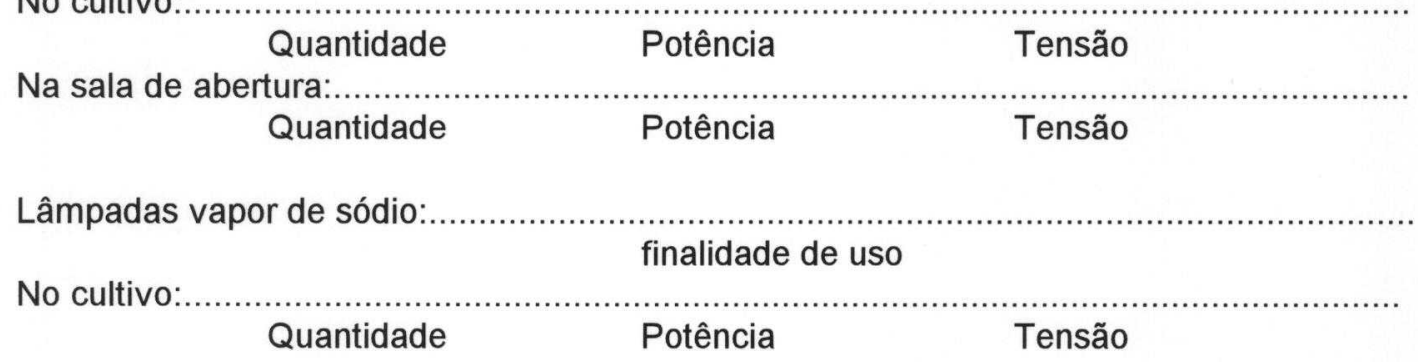

Na sala de abertura. 
Horas de trabalho diário das lâmpadas incandescentes:

No cultivo: Na sala desde até desde até

Horas de trabalho diário das lâmpadas de vapor de sódio:

No cultivo: Na sala:

desde até desde até

Disposição física das lâmpadas incandescentes:

No cultivo

Na sala de abertura.

Disposição física das lâmpadas de vapor de sódio:

No cultivo

Na sala de abertura.

Acendido e desligado dos elementos de iluminação . No cultivo

Na sala de abertura.

Iluminância: precisado conseguido

Vida útil das lâmpadas

SUBLIMADORES

Finalidade de uso:

Potência

Horas de trabalho diário da:. 


\section{MOTORES PARA IRRIGAÇÃO}

Método de irrigação Frequência de irrigação.

Como controla a vazão:

Distância mais longa a ser irrigada:.

Pressão:.

da bomba

do orifício

Diâmetro da tubulação:...

Material da tubulação:

principal laterais

principal laterais

Potência nominal Pm:

Horas diárias de trabalho $\mathrm{hm}$ :

Controle do sistema de irrigação:

CÂMARA DE REFRIGERAÇÃo

Quantidade de câmaras:

Dimensões:

\begin{tabular}{|c|c|c|}
\hline $\begin{array}{l}\text { comprimento } \\
\text { Isolamento térmico:.................. }\end{array}$ & largo & altura \\
\hline tipo & & espesura \\
\hline quantidade & tensão & potência \\
\hline Ventiladores:... & tensãso & potência \\
\hline quantidade & voltagem & potência \\
\hline
\end{tabular}

Temperatura ambiente:

Temperatura interna:

Umidade relativa do ar na câmara:

Quantidade média do material armazenado: . $\mathrm{kg}$

Tempo de permanência do material na câmara:

mínimo máximo recomendável

\section{ESCRITÓRIOS E SERVIÇOS GERAIS}

Potência total dos escritórios e serviços gerais :

Horas de uso diário:

\section{OBSERVAÇÕES:}


ANEXO D: RESULTADOS DA PESQUISA DE CAMPO

Tabela D.1: CULTIVO DE ROSAS: DADOS GERAIS.

\begin{tabular}{|c|c|c|c|c|c|}
\hline \multirow{2}{*}{$\begin{array}{l}\text { NOME DA } \\
\text { AGROINDÚSTRIA }\end{array}$} & \multirow{2}{*}{$\begin{array}{l}\text { ÁREA } \\
\text { (ha) }\end{array}$} & \multicolumn{2}{|c|}{ NÚMER FUNCIONÁRIOS } & \multirow{2}{*}{$\begin{array}{l}\text { POTÉNCIA } \\
\text { CONTRATAD } \\
(\mathrm{kW})\end{array}$} & \multirow{2}{*}{$\begin{array}{c}\text { ENERGIA } \\
\text { MÉDIA } \\
\text { (kWh/mês) }\end{array}$} \\
\hline & & TECNICO & PRODUÇẢO & & \\
\hline Rosinvar-Cayambe * & 4,0 & 8 & 52 & 55 & 717 \\
\hline Rosas del Ecuador & 11,0 & 16 & 164 & 165 & 26.840 \\
\hline Plan flor & 8,5 & 15 & 120 & 71 & 27.093 \\
\hline Pontetresa & 6,0 & 12 & 86 & 50 & 18.690 \\
\hline Rosedex & 2,0 & 6 & 24 & 10 & 2.938 \\
\hline Flores de la montaña & 8,0 & 18 & 112 & 85 & 19.396 \\
\hline Flores del Cayambe & 13,0 & 20 & 170 & 132 & 31.800 \\
\hline Florifrut & 4,0 & 6 & 54 & 11 & 8.590 \\
\hline Rosinvar-Tabacundo & 5,0 & 10 & 70 & 80 & 11.714 \\
\hline Florinsa & 11,2 & 20 & 160 & 110 & 25.330 \\
\hline Agroflora & 8,5 & 14 & 126 & 102 & 23.080 \\
\hline Floricultura & 7,0 & 14 & 90 & 30 & 7.656 \\
\hline Florvalle & 4,0 & 10 & 56 & 29 & 5.796 \\
\hline Astroflores & 4,0 & 8 & 60 & 25 & 13.427 \\
\hline Waserig & 3,0 & 5 & 40 & 10 & 6.341 \\
\hline Royal flowers & 6,0 & 12 & 78 & 40 & 15.160 \\
\hline Rosas del monte & 7,5 & 20 & 100 & 107 & 28.004 \\
\hline Vegaflor & 9,0 & 18 & 147 & 60 & 20.078 \\
\hline
\end{tabular}

Fonte: Usos finais nas agroindústrias. Ibarra Janeiro 1994

* É uma agroindústria nova, ainda não tem instalado todo o equipamento

Tabela D.2: CULTIVO DE ROSAS: CÁLCULO DE POTÉNCIA CONTRATADAE ENERGIA MÉDIA MENSAL POR HECTARE E POR FUNCIONÂRIO

1)POTÊNCIA POR HECTARE, 2)ENERGIA POR HECTARE, 3) POTÊNCIA POR FUNCIONÁRIO, 4)ENERGIA POR FUNCIONÁRIO, 5) FUNCIONÁRIO POR HECTARE

\begin{tabular}{|c|c|c|c|c|c|}
\hline NOME DA & 1) & 2) & 3) & 4) & 5) \\
\hline AGROINDÚSTRIA & $\mathrm{kW} / \mathrm{ha}$ & $\mathrm{kWh} / \mathrm{ha}$ & $\mathrm{kW} /$ Func & $\mathrm{kWh} /$ Func & Func/ha \\
\hline Rosinvar-Cayambe & 13,75 & 179 & 0,92 & 11,95 & 15 \\
\hline Rosas del Ecuador & 15,00 & 2.440 & 0,92 & 149,11 & 16 \\
\hline Plan flor & 8,35 & 3.187 & 0,53 & 200,69 & 16 \\
\hline Pontetresa & 8,33 & 3.115 & 0,51 & 190,71 & 16 \\
\hline Rosedex & 5,00 & 1.469 & 0,33 & 97,93 & 15 \\
\hline Flores de la montaña & 10,63 & 2.425 & 0,65 & 149,20 & 16 \\
\hline Flores del Cayambe & 10,15 & 2.446 & 0,69 & 167,37 & 15 \\
\hline Florifrut & 2,75 & 2.148 & 0,18 & 143,17 & 15 \\
\hline Rosinvar-Tabacundo & 16,00 & 2.343 & 1,00 & 146,43 & 16 \\
\hline Florinsa & 9,82 & 2.262 & 0,61 & 140,72 & 16 \\
\hline Agroflora & 12,00 & 2.715 & 0,73 & 164,86 & 16 \\
\hline Floricultura & 4,29 & 1.094 & 0,29 & 73,62 & 15 \\
\hline Florvalle & 7,25 & 1.449 & 0,44 & 87,82 & 17 \\
\hline Astroflores & 6,25 & 3.357 & 0,37 & 197,46 & 17 \\
\hline Waserig & 3,33 & 2.114 & 0,22 & 140,91 & 15 \\
\hline Royal flowers & 6,67 & 2.527 & 0,44 & 168,44 & 15 \\
\hline Rosas del monte & 14,27 & 3.734 & 0,89 & 233,37 & 16 \\
\hline Vegaflor & 6,67 & 2.231 & 0,36 & 121,68 & 18 \\
\hline MÉDIA & 8,92 & 2.291 & 0,56 & 143,64 & 16 \\
\hline DESVIO & 4,02 & 852 & 0,25 & 51,77 & 1 \\
\hline
\end{tabular}


Tabela D.3: CULTIVO DE ROSAS: SUBLIMADORES

\begin{tabular}{|c|c|c|c|c|c|c|c|c|}
\hline $\begin{array}{l}\text { NOME DA } \\
\text { AGROINDÚSTRIA }\end{array}$ & $\begin{array}{l}\text { ÁREA } \\
\text { (ha) }\end{array}$ & $\begin{array}{l}\text { POTÉNCIA } \\
\text { INSTALADA } \\
(\mathrm{kW})\end{array}$ & $\begin{array}{c}\text { HORAS } \\
\text { DIÁRIAS } \\
\text { (h) }\end{array}$ & $\begin{array}{c}\text { FATOR } \\
\text { UTILIZAÇÃO } \\
(\%)\end{array}$ & $\begin{array}{c}\text { ENERGIA } \\
\text { ANUAL } \\
(\mathrm{kWh})\end{array}$ & $\begin{array}{l}\text { POTÉNCIA } \\
\text { POR ha } \\
\text { (kW/ha) }\end{array}$ & $\begin{array}{c}\text { ENERGIAVMES } \\
\text { POR ha } \\
(\mathrm{kWh} / \mathrm{ha})\end{array}$ & $\begin{array}{c}\text { PORCENTAG } \\
\text { DE USO } \\
(\%)\end{array}$ \\
\hline Rosinvar-Cayambe & 4,0 & & & & & & & \\
\hline Rosas del Ecuador & 11,0 & 58,3 & 7 & 1 & 146.916 & 5,30 & 1.113 & $46,4 \%$ \\
\hline Plan flor & 8,5 & 61,2 & 8 & 1 & 176.256 & 7,20 & 1.728 & $50,5 \%$ \\
\hline Pontetresa & 6,0 & 43,2 & 8 & 1 & 124.416 & 7,20 & 1.728 & $51,3 \%$ \\
\hline Rosedex & 2,0 & & & & & & & \\
\hline Flores de la montaña & 8,0 & 51,2 & 6 & 1 & 110.592 & 6,40 & 1.152 & $43,0 \%$ \\
\hline Flores del Cayambe & 13,0 & 94,0 & 7 & 1 & 236.880 & 7,23 & 1.518 & $56,0 \%$ \\
\hline Florifrut & 4,0 & 20,0 & 4 & 1 & 28.800 & 5,00 & 600 & $28,5 \%$ \\
\hline Rosinvar- Tabacundo & 5,0 & 14,0 & 8 & 1 & 40.320 & 2,80 & 672 & $25,8 \%$ \\
\hline Florinsa & 11,2 & 47,0 & 4 & 1 & 67.680 & 4,20 & 504 & $20,2 \%$ \\
\hline Agroflora & 8,5 & 39,0 & 7 & 1 & 98.280 & 4,59 & 964 & $35,5 \%$ \\
\hline Floricultura & 7,0 & & & & & & & \\
\hline Florvalle & 4,0 & & & & & & & \\
\hline Astroflores & 4,0 & 14,0 & 12 & 1 & 60.480 & 3,50 & 1.260 & $39,7 \%$ \\
\hline Waserig & 3,0 & 12,0 & 5 & 1 & 21.600 & 4,00 & 600 & $30,9 \%$ \\
\hline Royal flowers & 6,0 & 32,0 & 8 & 1 & 92.160 & 5,33 & 1.280 & $50,5 \%$ \\
\hline Rosas del monte & 7,5 & 61,2 & 8 & 1 & 176.256 & 8,16 & 1.958 & $50,1 \%$ \\
\hline Vegaflor & 9,0 & 56,0 & 6 & 1 & 120.960 & 6,22 & 1.120 & $53,6 \%$ \\
\hline MÉDIA & & & 6,5 & & & 5,13 & 1.077 & $38,5 \%$ \\
\hline DESVIO & & & 2,7 & & & 2,10 & 536 & \\
\hline
\end{tabular}


Tabela D.4: CULTIVO DE ROSAS: SISTEMA DE IRRIGAÇÃO

\begin{tabular}{|c|c|c|c|c|c|c|c|c|c|c|}
\hline $\begin{array}{c}\text { NOME DA } \\
\text { AGROINDÚSTRIA }\end{array}$ & $\begin{array}{l}\text { ÁREA } \\
\text { (ha) }\end{array}$ & $\begin{array}{l}\text { POTÊNCIA } \\
\text { INSTALADA } \\
(k w)\end{array}$ & $\begin{array}{l}\text { FATOR } \\
\text { COINCID } \\
(\xi)\end{array}$ & $\begin{array}{c}\text { POTÊNCIA } \\
\text { COINCIDEN } \\
(\mathrm{kW})\end{array}$ & $\begin{array}{c}\text { HORAS } \\
\text { DIÁRIAS } \\
\text { (h) }\end{array}$ & $\begin{array}{c}\text { FATOR } \\
\text { UTILI ZAÇÃO } \\
(₹) .\end{array}$ & $\begin{array}{l}\text { ENERGIA } \\
\text { ANUAL } \\
(\mathrm{kWh})\end{array}$ & $\begin{array}{l}\text { POTÊNCIA } \\
\text { POR ha } \\
(\mathrm{kW} / \mathrm{ha})\end{array}$ & $\begin{array}{c}\text { ENERGI/MÊS } \\
\text { POR ha } \\
\text { (kwh/ha) }\end{array}$ & $\begin{array}{l}\text { PORCENTAG } \\
\text { DE USO } \\
\text { (8) }\end{array}$ \\
\hline var-Cayambe & 4,0 & & & & & & & & & \\
\hline del Ecuador & 11,0 & 34,0 & 0,89 & 30,3 & 8 & 0,75 & 65.362 & 3,09 & 495,2 & $20,6 \%$ \\
\hline or & 8,5 & 24,0 & 0,66 & 15,8 & 8 & 0,75 & 34.214 & 2,82 & 335,4 & $9,8 \%$ \\
\hline resa & 6,0 & 16,4 & 0,50 & 8,2 & 8 & 0,75 & 17.712 & 2,73 & 246,0 & $7,3 \%$ \\
\hline ex & 2,0 & 5,2 & 1,00 & 5,2 & 3 & 1,00 & 5.616 & 2,60 & 234,0 & $17,5 \%$ \\
\hline de la montaña & 8,0 & 13,0 & 1,00 & 13,0 & 6 & 0,83 & 23.306 & 1,63 & 242,8 & $9,1 \%$ \\
\hline del Cayambe & 13,0 & 37,3 & 0,70 & 26,1 & 7 & 1,00 & 65.797 & 2,87 & 421,8 & $15,6 \%$ \\
\hline 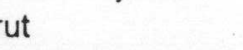 & 4,0 & 13,0 & 1,00 & 13,0 & 5 & 1,00 & 23.400 & 3,25 & 487,5 & $23,1 \%$ \\
\hline var-Tabacundo & 5,0 & 14,0 & 1,00 & 14,0 & 8 & 0,75 & 30.240 & 2,80 & 504,0 & $19,3 \%$ \\
\hline sa & 11,2 & 39,0 & 0,49 & 19,1 & 8 & 1,00 & 55.037 & 3,48 & 409,5 & $16,4 \%$ \\
\hline ora & 8,5 & 26,0 & 1,00 & 26,0 & 7 & 1,00 & 65.520 & 3,06 & 642,4 & $23,7 \%$ \\
\hline ultura & 7,0 & 10,0 & 1,00 & 10,0 & 6 & 0,67 & 14.472 & 1,43 & 172,3 & $17.3 \%$ \\
\hline alle & 4,0 & 7,5 & 1,00 & 7,5 & 5 & 1,00 & 13.500 & 1,88 & 281,3 & $19,6 \%$ \\
\hline lores & 4,0 & 19,0 & 0,63 & 12,0 & 8 & 0,75 & 25.855 & 4,75 & 538,7 & $17.0 \%$ \\
\hline rig & 3,0 & 12,0 & 0,80 & 9,6 & 5 & 0,80 & 13.824 & 4,00 & 384,0 & $19,8 \%$ \\
\hline flowers & 6,0 & 13,4 & 0,82 & 11,0 & 6 & 1,00 & 23.734 & 2,23 & 329,6 & $13,0 \%$ \\
\hline del monte & 7,5 & 34,0 & 0,76 & 25,8 & 8 & 0,50 & 37.210 & 4,53 & 413,4 & $10,6 \%$ \\
\hline lor & 9,0 & 15,0 & 1,00 & 15,0 & 7 & 1,00 & 37.800 & 1,67 & 350,0 & $16.7 \%$ \\
\hline IÉDIA & & & & & 7 & & 32.506 & 2,87 & 381,6 & $15,4 \%$ \\
\hline ESVIO & & & & & 1 & & 18.958 & 0,93 & 122,3 & \\
\hline
\end{tabular}


Tabela D.5: CULTIVO DE ROSAS: CÂMARA DE REFRIGERAÇÃO

\begin{tabular}{|c|c|c|c|c|c|c|c|c|c|c|}
\hline $\begin{array}{c}\text { NOMB DA } \\
\text { AGROINÚSTRIA }\end{array}$ & $\begin{array}{l}\text { ÁRBA } \\
\text { (ha) }\end{array}$ & $\begin{array}{l}\text { POTÊNCIA } \\
\text { INSTALADA } \\
(\mathrm{kW})\end{array}$ & $\begin{array}{l}\text { VOLUMEN } \\
\text { CÂMARA } \\
(\mathrm{m} 3)\end{array}$ & $\begin{array}{c}\text { HORAS } \\
\text { DIÁRIAS } \\
\text { (h) }\end{array}$ & $\begin{array}{c}\text { FATOR } \\
\text { UTILIZAÇÃO } \\
(8) \\
\end{array}$ & $\begin{array}{c}\text { ENERGIA } \\
\text { ANUAL } \\
(\mathrm{kWh})\end{array}$ & $\begin{array}{l}\text { POTÊNCIA } \\
\text { POR ha } \\
(\mathrm{kW} / \mathrm{ha})\end{array}$ & $\begin{array}{c}\text { ENERGIA/MÊS } \\
\text { POR ha } \\
(\mathrm{kWh} / \mathrm{ha})\end{array}$ & $\begin{array}{l}\text { VOLUMEN } \\
\text { POR ha } \\
(\mathrm{m} 3 / \mathrm{ha})\end{array}$ & $\begin{array}{c}\text { PORCENT } \\
\text { DE USO } \\
(z)\end{array}$ \\
\hline sinvar-Cayambe & 4,0 & & & & & & & & & \\
\hline sas del Ecuador & 11,0 & 15,0 & 150,0 & 24 & 0,66 & 85.536 & 1,36 & 648,0 & 13,6 & $27.0 \%$ \\
\hline n flor & 8,5 & 21,0 & 360,0 & 24 & 0,66 & 119.750 & 2,47 & 1. 174,0 & 42,4 & $34,3 \%$ \\
\hline htetresa & 6,0 & 15,0 & 300,0 & 24 & 0,66 & 85.536 & 2,50 & 1. 188,0 & 50,0 & $35,3 \%$ \\
\hline sedex & 2,0 & 4,1 & 100,0 & 24 & 0,66 & 23.551 & 2,07 & 981,3 & 50,0 & $73,2 \%$ \\
\hline res de la montaña & 8,0 & 20,0 & 150,0 & 24 & 0,66 & 114.048 & 2,50 & 1. 188,0 & 18,8 & $44,3 \%$ \\
\hline res del Cayambe & 13,0 & 15,0 & 150,0 & 24 & 0,66 & 85.536 & 1,15 & 548,3 & 11,5 & $20,2 \%$ \\
\hline rifrut & 4,0 & 7,5 & 180,0 & 24 & 0,66 & 42.768 & 1,88 & 891,0 & 45,0 & $42,3 \%$ \\
\hline sinvar-Tabacundo & 5,0 & 12,0 & 122,0 & 24 & 0,66 & 68.429 & 2,40 & $1.140,5$ & 24,4 & $43,8 \%$ \\
\hline rinsa & 11,2 & 34,0 & 688,0 & 24 & 0,66 & 193.882 & 3,04 & $1.442,6$ & 61,4 & $57.8 \%$ \\
\hline oflora & 8,5 & 16,0 & 423,0 & 24 & 0,66 & 91.238 & 1,88 & 894,5 & 49,8 & $33,0 \%$ \\
\hline ricultura & 7,0 & 9,5 & 400,0 & 24 & 0,66 & 54.173 & 1,36 & 644,9 & 57,1 & $64,8 \%$ \\
\hline rvalle & 4,0 & 8,4 & 195,0 & 24 & 0,66 & 47.900 & 2,10 & 997,9 & 48,8 & $69,6 \%$ \\
\hline roflores & 4,0 & 10,8 & 75,0 & 24 & 0,66 & 61.586 & 2,70 & $1.283,0$ & 18,8 & $40,4 \%$ \\
\hline serig & 3,0 & 5,4 & 26,0 & 24 & 0,66 & 30.793 & 1.80 & 855,4 & 8,7 & $44,0 \%$ \\
\hline yal flowers & 6,0 & 10,4 & 108,0 & 24 & 0,66 & 59.305 & 1,73 & 823,7 & 18,0 & $32,5 \%$ \\
\hline sas del monte & 7,5 & 22,0 & 690,0 & 24 & 0,66 & 125.453 & 2,93 & $1.393,9$ & 92,0 & $35,7 \%$ \\
\hline gaflor & 9,0 & 9,0 & 155,0 & 24 & 0,66 & 51.322 & 1,00 & 475,2 & 17,2 & $22,7 \%$ \\
\hline MÉDIA & & & & 24 & & 78.871 & 2,05 & 974,7 & 36,9 & $39,3 \%$ \\
\hline DESVIO & & & & & & 40.863 & 0.59 & 281,4 & 22,1 & \\
\hline
\end{tabular}


Tabela D.6: CULTIVO DE ROSAS: ESCRITÓRIOS E SERVIÇOS GERAIS

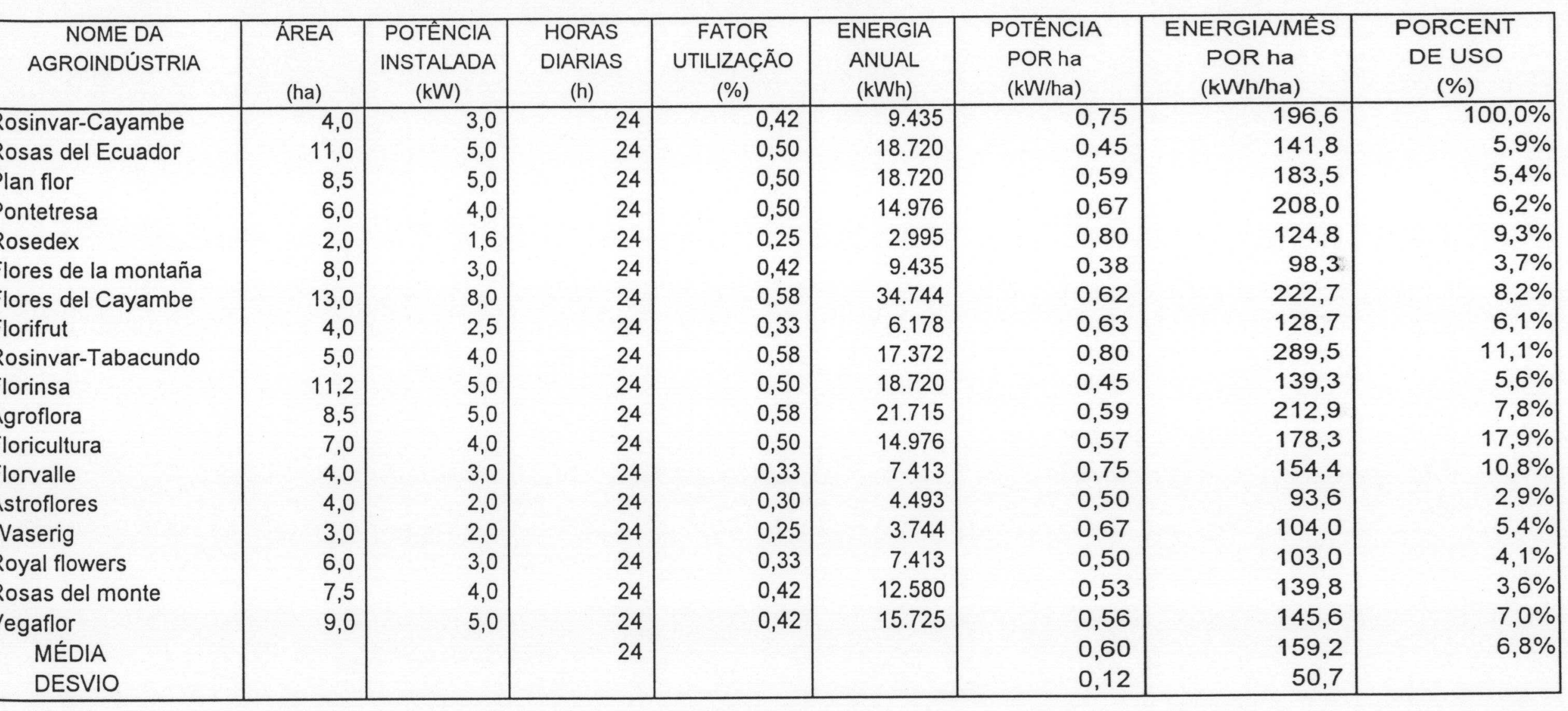


Tabela D.7: CULTIVO DE ROSAS: COMPARAÇÃO DE ENERGIA CALCULADA COM ENERGIA MÉDIA MENSAL REGISTRADA NA EMELNORTE

\begin{tabular}{|c|c|c|c|c|c|}
\hline $\begin{array}{c}\text { NOME DA } \\
\text { AGROINDÚSTRIA }\end{array}$ & $\begin{array}{c}\text { ENERGI/M } \\
\text { CALCULAD } \\
\text { POR ha } \\
\text { (kWh/ha) }\end{array}$ & $\begin{array}{c}\text { ENERGI/M } \\
\text { CALCULADO } \\
\text { TOTAL } \\
(\mathrm{kWh})\end{array}$ & $\begin{array}{c}\text { ENERGIA } \\
\text { MÉDIA } \\
\text { MENSAL } \\
\text { (kWh) }\end{array}$ & DIFERENÇA & $\begin{array}{c}\text { PORCENT } \\
\text { DE ERRO } \\
(\%)\end{array}$ \\
\hline Rosinvar-Cayambe & 197 & 786 & 717 & (69) & $-8,8 \%$ \\
\hline Rosas del Ecuador & 2.398 & 26.378 & 26.840 & 462 & $1,8 \%$ \\
\hline Plan flor & 3.421 & 29.078 & 27.093 & (1.985) & $-6,8 \%$ \\
\hline Pontetresa & 3.370 & 20.220 & 18.690 & (1.530) & $-7,6 \%$ \\
\hline Rosedex & 1.340 & 2.680 & 2.938 & 258 & $9,6 \%$ \\
\hline Flores de la montaña & 2.681 & 21.448 & 19.396 & (2.052) & $-9,6 \%$ \\
\hline Flores del Cayambe & 2.711 & 35.246 & 31.800 & $(3.446)$ & $-9,8 \%$ \\
\hline Florifrut & 2.107 & 8.429 & 8.590 & 161 & $1,9 \%$ \\
\hline Rosinvar-Tabacundo & 2.606 & 13.030 & 11.714 & (1.316) & $-10,1 \%$ \\
\hline Florinsa & 2.495 & 27.943 & 25.330 & (2.613) & $-9,4 \%$ \\
\hline Agroflora & 2.713 & 23.063 & 23.080 & 17 & $0,1 \%$ \\
\hline Floricultura & 995 & 6.968 & 7.656 & 688 & $9,9 \%$ \\
\hline Florvalle & 1.434 & 5.734 & 5.796 & 62 & $1,1 \%$ \\
\hline Astroflores & 3.175 & 12.701 & 13.427 & 726 & $5,7 \%$ \\
\hline Waserig & 1.943 & 5.830 & 6.341 & 511 & $8,8 \%$ \\
\hline Royal flowers & 2.536 & 15.218 & 15.160 & (58) & $-0,4 \%$ \\
\hline Rosas del monte & 3.906 & 29.292 & 28.004 & (1.288) & $-4,4 \%$ \\
\hline Vegaflor & 2.091 & 18.817 & 20.078 & 1.261 & $6,7 \%$ \\
\hline
\end{tabular}

Tabela D.8: CULTIVO DE ROSAS: COMPARAÇÃO DE POTÊNCIA CALCULADA COM POTENNCIA CONTRATADA

\begin{tabular}{|c|c|c|c|c|c|}
\hline $\begin{array}{c}\text { NOME DA } \\
\text { AGROINDÚSTRIA }\end{array}$ & $\begin{array}{c}\text { POTÉNCIA } \\
\text { CALCULAD } \\
\text { POR ha } \\
\text { (kW/ha) } \\
\end{array}$ & $\begin{array}{c}\text { POTÉNCIA } \\
\text { INSTALADA } \\
\text { TOTAL } \\
(\mathrm{kW}) \\
\end{array}$ & $\begin{array}{l}\text { POTÉNCIA } \\
\text { CONTRAT } \\
(\mathrm{kW})\end{array}$ & DIFERENÇ & $\begin{array}{c}\text { PORCENT } \\
\text { DE ERRO } \\
(\%)\end{array}$ \\
\hline Rosinvar-Cayambe & 0,75 & 3 & 55 & 52,0 & $94,5 \%$ \\
\hline Rosas del Ecuador & 10,21 & 112 & 165 & 52,7 & $31,9 \%$ \\
\hline Plan flor & 13,08 & 111 & 71 & $-40,2$ & $-56,6 \%$ \\
\hline Pontetresa & 13,10 & 79 & 50 & $-28,6$ & $-57,2 \%$ \\
\hline Rosedex & 5,47 & 11 & 10 & $-0,9$ & $-9,3 \%$ \\
\hline Flores de la montaña & 10,90 & 87 & 85 & $-2,2$ & $-2,6 \%$ \\
\hline Flores del Cayambe & 11,87 & 154 & 132 & $-22,3$ & $-16,9 \%$ \\
\hline Florifrut & 10,75 & 43 & 11 & $-32,0$ & $-290,9 \%$ \\
\hline Rosinvar-Tabacundo & 8,80 & 44 & 80 & 36,0 & $45,0 \%$ \\
\hline Florinsa & 11,16 & 125 & 110 & $-15,0$ & $-13,6 \%$ \\
\hline Agroflora & 10,12 & 86 & 102 & 16,0 & $15,7 \%$ \\
\hline Floricultura & 3,36 & 24 & 30 & 6,5 & $21,7 \%$ \\
\hline Florvalle & 4,73 & 19 & 29 & 10,1 & $34,8 \%$ \\
\hline Astroflores & 11,45 & 46 & 25 & $-20,8$ & $-83,2 \%$ \\
\hline Waserig & 10,47 & 31 & 10 & $-21,4$ & $-214,0 \%$ \\
\hline Royal flowers & 9,80 & 59 & 40 & $-18,8$ & $-47,0 \%$ \\
\hline Rosas del monte & 16,16 & 121 & 107 & $-14,2$ & $-13,3 \%$ \\
\hline Vegaflor & 9,44 & 85 & 60 & $-25,0$ & $-41,7 \%$ \\
\hline
\end{tabular}


Tabela D.9: CULTIVO DE GIPSÓFILA: DADOS GERAIS

\begin{tabular}{|c|c|c|c|c|c|}
\hline \multirow{2}{*}{$\begin{array}{l}\text { NOME DA } \\
\text { AGROINDÚSTRIA }\end{array}$} & \multirow{2}{*}{$\begin{array}{l}\text { ÁREA } \\
\text { (ha) }\end{array}$} & \multicolumn{2}{|c|}{ NÚM FUNCIONÁRIOS } & \multirow{2}{*}{$\begin{array}{c}\text { POTÉNCIA } \\
\text { CONTRATADA } \\
(\mathrm{kW})\end{array}$} & \multirow{2}{*}{$\begin{array}{c}\text { ENERGIA } \\
\text { MÉDIA } \\
\text { (kWh/mes) }\end{array}$} \\
\hline & & TECNICO & PRODUÇÃO & & \\
\hline Agrizama & 7,5 & 20 & 130 & 595 & 92.720 \\
\hline Niña María & 1,5 & 5 & 22 & 10 & 6.340 \\
\hline Proflores & 3,3 & 14 & 50 & 92 & 15.943 \\
\hline
\end{tabular}

Fonte: Usos finais nas agroindústrias. Ibarra Janeiro 1994

Tabela D.10: CULTIVO DE GIPSÓFILA: CALCULO DE POTÊNCIA CONTRATADA E ENERGIA MÉDIA MENSAL POR HECTARE E POR FUNCIONÁRIO

1)POTENNCIA POR HECTARE, 2)ENERGIA POR HECTARE

3)POTÊNCIA POR FUNCIONÁRIO, 4)ENERGIA POR FUNCIONÁRIO

5)FUNCIONÁRIO POR HECTARE

\begin{tabular}{|l|r|r|r|r|r|}
\hline NOME DA & \multicolumn{1}{|c|}{$\begin{array}{c}\text { 1) } \\
\text { AGROINDÚSTRIA }\end{array}$} & $\begin{array}{c}\text { 2) } \\
\text { kWha }\end{array}$ & $\begin{array}{c}\text { 3) } \\
\text { kW/hanc }\end{array}$ & $\begin{array}{c}\text { 4) } \\
\text { kWh/Func }\end{array}$ & \multicolumn{1}{c|}{$\begin{array}{c}\text { 5) } \\
\text { Func/ha }\end{array}$} \\
\hline Agrizama & 79,33 & 12.363 & 3,97 & 618,13 & 20 \\
Niña María & 6,67 & 4.227 & 0,37 & 234,81 & 18 \\
Proflores & 27,88 & 4.831 & 1,44 & 249,11 & 19 \\
MÉDIA & 37,96 & 7.140 & 1,92 & 367,35 & 19 \\
DESVIO & 30,51 & 3.701 & 1,51 & 177,42 & 1 \\
\hline
\end{tabular}


Tabela D.11: CULTIVO DE GIPSÓFILA: ILUMINAÇÃO DO CULTIVO

ÂMPADAS INCANDESCENTES

\begin{tabular}{|c|c|c|c|c|c|c|c|c|c|c|}
\hline $\begin{array}{l}\text { NOME DA } \\
\text { OINDÚSTRIA }\end{array}$ & $\begin{array}{l}\text { ÁREA } \\
\text { (ha) }\end{array}$ & $\begin{array}{c}\text { POTÉNCIA } \\
\text { INSTALADA } \\
(\mathrm{kW})\end{array}$ & $\begin{array}{c}\text { FATOR } \\
\text { COINCID } \\
(\%)\end{array}$ & $\begin{array}{l}\text { POTÊNCIA } \\
\text { COINCIDEN } \\
(\mathrm{kW})\end{array}$ & $\begin{array}{l}\text { HORAS } \\
\text { DIÁRIAS } \\
\text { (h) }\end{array}$ & $\begin{array}{c}\text { FATOR } \\
\text { UTILIZAÇÃO } \\
(\%)\end{array}$ & $\begin{array}{l}\text { ENERGIA } \\
\text { ANUAL } \\
\text { (kWh) }\end{array}$ & $\begin{array}{l}\text { POTÉNCIA } \\
\text { POR ha } \\
\text { (kW/ha) }\end{array}$ & $\begin{array}{c}\text { ENERGIAIM } \\
\text { POR ha } \\
\text { (kWh/ha) }\end{array}$ & $\begin{array}{c}\text { PORCENT } \\
\text { DE USO } \\
(\%)\end{array}$ \\
\hline १а & 7,5 & 780,0 & 0,33 & 257,4 & 11 & 0,86 & 876.601 & 104,00 & 9.740 & $78,7 \%$ \\
\hline aria & $\begin{array}{l}1,5 \\
3,3\end{array}$ & 96,0 & 0,33 & 31,7 & 5 & 0,7 & $\begin{array}{r}39.917 \\
0\end{array}$ & $\begin{array}{l}64,00 \\
84,00\end{array}$ & $\begin{array}{r}2.218 \\
0 \\
5.979\end{array}$ & $\begin{array}{r}47,9 \% \\
0,0 \% \\
70,3 \%\end{array}$ \\
\hline
\end{tabular}

\section{ÂMPADAS A VAPOR DE SÓDIO}

\begin{tabular}{|c|c|c|c|c|c|c|c|c|c|c|}
\hline $\begin{array}{l}\text { NOME DA } \\
\text { OINDÚSTRIA }\end{array}$ & $\begin{array}{l}\text { ÁREA } \\
\text { (ha) }\end{array}$ & $\begin{array}{c}\text { POTÊNCIA } \\
\text { INSTALADA } \\
(\mathrm{kW})\end{array}$ & $\begin{array}{c}\text { FATOR } \\
\text { COINCID } \\
(\%)\end{array}$ & $\begin{array}{c}\text { POTÉNCIA } \\
\text { COINCIDEN } \\
(\mathrm{kW})\end{array}$ & $\begin{array}{c}\text { HORAS } \\
\text { DIÁRIAS } \\
\text { (h) }\end{array}$ & $\begin{array}{c}\text { FATOR } \\
\text { UTILIZAÇÃO } \\
(\%)\end{array}$ & $\begin{array}{c}\text { ENERGIA } \\
\text { ANUAL } \\
\text { (kWh) }\end{array}$ & $\begin{array}{c}\text { POTÊNCIA } \\
\text { POR ha } \\
\text { (kW/ha) }\end{array}$ & $\begin{array}{c}\text { ENERGIAVM } \\
\text { POR ha } \\
\text { (kWh/ha) }\end{array}$ & $\begin{array}{c}\text { PORCENT } \\
\text { DE USO } \\
(\%)\end{array}$ \\
\hline Ila & $\begin{array}{l}7,5 \\
1,5 \\
3,3\end{array}$ & 54,0 & 1 & 54,0 & 4 & 1 & $\begin{array}{r}0 \\
0 \\
77.760\end{array}$ & $\begin{array}{r}0,00 \\
0,00 \\
16,36\end{array}$ & $\begin{array}{r}0 \\
0 \\
1.964\end{array}$ & $37,9 \%$ \\
\hline
\end{tabular}


Tabela D.12: CULTIVO DE GIPSÓFILA: ILUMINAÇÃO DA SALA DE ABERTURA

LÂMPADAS INCANDESCENTES

\begin{tabular}{|c|c|c|c|c|c|c|c|c|c|c|}
\hline $\begin{array}{l}\text { NOME DA } \\
\text { ROINDÚSTRIA }\end{array}$ & $\begin{array}{l}\text { ÁREA } \\
\text { (ha) }\end{array}$ & $\begin{array}{c}\text { POTÉNCIA } \\
\text { INSTALAD } \\
(\mathrm{kW})\end{array}$ & $\begin{array}{c}\text { FATOR } \\
\text { COINCIDE } \\
(\%)\end{array}$ & $\begin{array}{l}\text { POTÉNCIA } \\
\text { COINCIDEN } \\
(\mathrm{kW})\end{array}$ & $\begin{array}{l}\text { HORAS } \\
\text { DIÁRIAS } \\
\text { (h) }\end{array}$ & $\begin{array}{c}\text { FATOR } \\
\text { UTILIZAÇĀOO } \\
(\%)\end{array}$ & $\begin{array}{l}\text { ENERGIA } \\
\text { ANUAL } \\
(\mathrm{kWh})\end{array}$ & $\begin{array}{l}\text { POTÉNCIA } \\
\text { POR ha } \\
\text { (kW/ha) }\end{array}$ & $\begin{array}{c}\text { ENERGIAVM } \\
\text { POR ha } \\
\text { (kW/h/ha) }\end{array}$ & $\begin{array}{c}\text { PORCENT } \\
\text { DE USO } \\
(\%)\end{array}$ \\
\hline$\overline{m a}$ & 7,5 & 28,8 & 0,5 & 14,4 & 15 & 1 & 77.760 & 3,84 & 864 & $7,0 \%$ \\
\hline María & 1,5 & 6,4 & 0,5 & 3,2 & 18 & 1 & 20.736 & 4,27 & 1.152 & $24,9 \%$ \\
\hline res & 3,3 & 14,4 & 0,5 & 7,2 & 24 & 1 & 62.208 & 4,36 & 1.571 & $\begin{array}{l}30,3 \% \\
11,9 \%\end{array}$ \\
\hline
\end{tabular}

LÂMPADA A VAPOR DE SÓDIO

\begin{tabular}{|c|c|c|c|c|c|c|c|c|c|c|}
\hline $\begin{array}{l}\text { NOME DA } \\
\text { ROINDÚSTRIA }\end{array}$ & $\begin{array}{l}\text { ÁREA } \\
\text { (ha) }\end{array}$ & $\begin{array}{l}\text { POTÉNCIA } \\
\text { INSTALAD } \\
(\mathrm{kW})\end{array}$ & $\begin{array}{c}\text { FATOR } \\
\text { COINCIDE } \\
(\%)\end{array}$ & $\begin{array}{l}\text { POTÉNCIA } \\
\text { COINCIDEN } \\
(\mathrm{kW})\end{array}$ & $\begin{array}{l}\text { HORAS } \\
\text { DIARIAS } \\
\text { (h) }\end{array}$ & $\begin{array}{c}\text { FATOR } \\
\text { UTILIZAÇĀO } \\
(\%)\end{array}$ & $\begin{array}{c}\text { ENERGIA } \\
\text { ANUAL } \\
\text { (kWh) }\end{array}$ & $\begin{array}{c}\text { POTÉNCIA } \\
\text { POR ha } \\
\text { (kW/ha) }\end{array}$ & $\begin{array}{c}\text { ENERGIAMM } \\
\text { POR ha } \\
\text { (kWh/ha) }\end{array}$ & $\begin{array}{c}\text { PORCENT } \\
\text { DE USO } \\
(\%)\end{array}$ \\
\hline & 7,5 & & & & & & 0 & 0,00 & 0 & $0,0 \%$ \\
\hline ría & 1,5 & & & & & & 0 & 0,00 & 0 & $0,0 \%$ \\
\hline & 3,3 & & & & & & 0 & 0,00 & 0 & $0,0 \%$ \\
\hline
\end{tabular}

pres

0,00

$0,0 \%$ 
Tabela D.13: CULTIVO DE GIPSÓFILA: SISTEMA DE IRRIGAÇÃO

\begin{tabular}{|c|c|c|c|c|c|c|c|c|c|c|}
\hline $\begin{array}{l}\text { NOME DA } \\
\text { ROINDÚSTRIA }\end{array}$ & $\begin{array}{l}\text { ÁREA } \\
\text { (ha) }\end{array}$ & $\begin{array}{l}\text { POTENCIA } \\
\text { INSTALADA } \\
(\mathrm{kW})\end{array}$ & $\begin{array}{c}\text { FATOR } \\
\text { COINCID } \\
(\%)\end{array}$ & $\begin{array}{l}\text { POTENNCIA } \\
\text { COINCIDEN } \\
(\mathrm{kW})\end{array}$ & $\begin{array}{l}\text { HORAS } \\
\text { DIÁRIAS } \\
\text { (h) }\end{array}$ & $\begin{array}{c}\text { FATOR } \\
\text { UTILIZAÇÃO } \\
(\%)\end{array}$ & $\begin{array}{c}\text { ENERGIA } \\
\text { ANUAL } \\
(\mathrm{kWh})\end{array}$ & $\begin{array}{c}\text { POTENCIA } \\
\text { POR ha } \\
\text { (kW/ha) }\end{array}$ & $\begin{array}{c}\text { ENERGIAMMES } \\
\text { POR ha } \\
\text { (kWh/ha) }\end{array}$ & $\begin{array}{c}\text { PORCENT } \\
\text { DE USO } \\
(\%)\end{array}$ \\
\hline $\mathrm{ma}$ & 7,5 & 30,0 & 1 & 30,0 & 5 & 1 & 54.000 & 4,00 & 600,0 & $4,8 \%$ \\
\hline María & 1,5 & 9,0 & 1 & 9,0 & 7 & 1 & 22.680 & 6,00 & $1.260,0$ & $27,2 \%$ \\
\hline $\begin{array}{l}\text { res } \\
\text { (incandescer }\end{array}$ & 3,3 & 9,0 & 1 & 9,0 & 5 & 1 & 16.200 & $\begin{array}{l}2,73 \\
5,00\end{array}$ & $\begin{array}{l}409,1 \\
930,0\end{array}$ & $\begin{array}{r}7,9 \% \\
10,9 \%\end{array}$ \\
\hline
\end{tabular}

Tabela D.14: CULTIVO DE GIPSÓFILA: CÂMARA DE REFRIGERAÇÃO

\begin{tabular}{|c|c|c|c|c|c|c|c|c|c|c|}
\hline $\begin{array}{l}\text { NOME DA } \\
\text { ROINDÚSTRIA }\end{array}$ & $\begin{array}{l}\text { ÁREA } \\
\text { (ha) }\end{array}$ & $\begin{array}{l}\text { POTÉNCIA } \\
\text { INSTALADA } \\
(\mathrm{kW})\end{array}$ & $\begin{array}{l}\text { VOLUMEN } \\
\text { CÂMARA } \\
\text { (m3) }\end{array}$ & $\begin{array}{l}\text { HORAS } \\
\text { DIÁRIAS } \\
\text { (h) }\end{array}$ & $\begin{array}{c}\text { FATOR } \\
\text { UTILIZAÇÃO } \\
(\%)\end{array}$ & $\begin{array}{c}\text { ENERGIA } \\
\text { ANUAL } \\
(\mathrm{kWh})\end{array}$ & $\begin{array}{l}\text { POTÉNCIA } \\
\text { POR Ha } \\
\text { (kW/ha) }\end{array}$ & $\begin{array}{c}\text { ENERGIAMÊS } \\
\text { POR Ha } \\
(\mathrm{kWh} / \mathrm{ha})\end{array}$ & $\begin{array}{l}\text { VOLUME } \\
\text { POR Ha } \\
\text { (m3/ha) }\end{array}$ & $\begin{array}{c}\text { PORCENT } \\
\text { DE USO } \\
(\%)\end{array}$ \\
\hline$m a$ & 7,5 & 16,0 & 196,0 & 24 & 0,66 & 91.238 & 2,13 & $1.013,8$ & 26,1 & $8,2 \%$ \\
\hline María & 1,5 & & & & & & 0,00 & 0,0 & 0,0 & $0,0 \%$ \\
\hline res & 3,3 & 6,0 & 95,0 & 24 & 0,66 & 34.214 & 1,82 & 864,0 & 28,8 & $\begin{array}{r}16,7 \% \\
6,0 \%\end{array}$ \\
\hline
\end{tabular}

Tabela D.15: CULTIVO DE GIPSÓFILA: ESCRITÓRIOS E SERVIÇOS GERAIS

\begin{tabular}{|c|c|c|c|c|c|c|c|c|}
\hline $\begin{array}{l}\text { NOME DA } \\
\text { ROINDÚSTRIA }\end{array}$ & $\begin{array}{l}\text { ÁREA } \\
\text { (ha) }\end{array}$ & $\begin{array}{c}\text { POTÊNCIA } \\
\text { INSTALADA } \\
(\mathrm{kW})\end{array}$ & $\begin{array}{c}\text { HORAS } \\
\text { DIÁRIAS } \\
\text { (h) }\end{array}$ & $\begin{array}{c}\text { FATOR } \\
\text { UTILIZAÇĀO } \\
(\%)\end{array}$ & $\begin{array}{c}\text { ENERGIA } \\
\text { ANUAL } \\
\text { (kWh) }\end{array}$ & $\begin{array}{l}\text { POTÊNCIA } \\
\text { POR Ha } \\
\text { (kW/ha) }\end{array}$ & $\begin{array}{c}\text { ENERGIAVMÊS } \\
\text { POR Ha } \\
\text { (kWh/ha) }\end{array}$ & $\begin{array}{c}\text { PORCENT } \\
\text { DE USO } \\
(\%)\end{array}$ \\
\hline 1a & 7,5 & 4,0 & 24 & 0,45 & 14.515 & 0,53 & 161,3 & $1,3 \%$ \\
\hline aría & 1,5 & 0,0 & 0 & & 0 & 0,00 & 0,0 & $0,0 \%$ \\
\hline es & 3,3 & 4,0 & 24 & 0,50 & 14.976 & 1,21 & 378,2 & $\begin{array}{l}7,3 \% \\
0,9 \%\end{array}$ \\
\hline
\end{tabular}


Tabela D.16: CULTIVO DE GIPSÓFILA: COMPARAÇÃO DE ENERGIA CALCULADA COM ENERGIA MÉDIA MENSAL REGISTRADA NA EMELNORTE

\begin{tabular}{|l|r|r|r|r|r|}
\hline AGROINDÚSTRIAS & $\begin{array}{c}\text { ENERGIA } \\
\text { CALCUL } \\
\text { POR ha }\end{array}$ & $\begin{array}{c}\text { ENERG/MÊS } \\
\text { CALCUL } \\
\text { TOTAL } \\
\text { PWERGIA }\end{array}$ & $\begin{array}{c}\text { DÉDIA } \\
\text { MENSAL }\end{array}$ & & $\begin{array}{c}\text { PORCENT } \\
\text { DE ERRO }\end{array}$ \\
& $(\mathrm{kWh} / \mathrm{ha})$ & $(\mathrm{kWh})$ & $(\mathrm{kWh})$ & $(\%)$ \\
\hline Agrisama & 12.379 & 92.843 & 92.720 & $-122,92$ & $-0,1 \%$ \\
Niña Maria & 4.630 & 6.944 & 6.340 & $-604,4$ & $-9,5 \%$ \\
Proflores & 5.186 & 17.113 & 15.943 & $-1170,2$ & $-7,3 \%$ \\
\hline
\end{tabular}

Tabela D.17: CULTIVO DE GIPSÓFILA: COMPARAÇÃO DA POTÊNCIA CALCULADA COM A POTÊNCIA CONTRATADA

\begin{tabular}{|l|r|r|r|r|r|}
\hline \multicolumn{1}{|c|}{$\begin{array}{c}\text { NOME DA } \\
\text { AGROINDÚSTRIA }\end{array}$} & $\begin{array}{c}\text { POTÉNCIA } \\
\text { CALCULAD } \\
\text { POR ha } \\
(\mathrm{kW} / \mathrm{ha})\end{array}$ & $\begin{array}{c}\text { POTENNCIA } \\
\text { INSTALADA } \\
\text { TOTAL } \\
(\mathrm{kW})\end{array}$ & $\begin{array}{c}\text { POTÉNCIA } \\
\text { CONTRAT }\end{array}$ & DIFEREN & \multicolumn{1}{c|}{$\begin{array}{r}\text { PORCENT } \\
\text { DE ERRO }\end{array}$} \\
\hline Agrisama & 114,5 & 859 & 595 & $-263,8$ & $(\mathrm{~kW})$ \\
Niña Maria & 74,3 & 111 & 10 & $-101,4$ & $-1014,0 \%$ \\
Proflores & 10,1 & 87 & 92 & 4,6 & $5,0 \%$ \\
\hline
\end{tabular}


Tabela D.18: CULTIVO DE CRAVOS: DADOS GERAIS

\begin{tabular}{|c|c|c|c|c|c|}
\hline \multirow{2}{*}{$\begin{array}{l}\text { NOME DA } \\
\text { AGROINDÚSTRIA }\end{array}$} & \multirow{2}{*}{$\begin{array}{l}\text { ÁREA } \\
\text { (ha) }\end{array}$} & \multicolumn{2}{|c|}{ NÚMER FUNCIONÁRIOS } & \multirow{2}{*}{$\begin{array}{l}\text { POTÊNCIA } \\
\text { CONTRATAD } \\
(\mathrm{kW})\end{array}$} & \multirow{2}{*}{$\begin{array}{c}\text { ENERGIA } \\
\text { MÉDIA } \\
\text { (kWh/mes) }\end{array}$} \\
\hline & & TECNICO & PRODUÇÃO & & \\
\hline Nerita flowers & 8,0 & 10 & 128 & 44 & 4.262 \\
\hline Florexpo & 5,0 & 8 & 72 & 20 & 4.148 \\
\hline
\end{tabular}

Fonte: Usos finais nas agroindústrias. Ibarra Janeiro 1994

Tabela D.19: CULTIVO DE CRAVOS: CÁLCULO DA POTÊNCIA CONTRATADA E ENERGIA MÉDIA MENSAL POR HECTARE E POR FUNCIONÁRIO

1)POTENNCIA POR HECTARE, 2)ENERGIA POR HECTARE

3)POTENNCIA POR FUNCIONÁRIO, 4)ENERGIA POR FUNCIONÁRIO

5)FUNCIONÁRIO POR HECTARE

\begin{tabular}{|l|r|r|r|r|r|}
\hline NOME DA & \multicolumn{1}{|c|}{$\begin{array}{c}\text { 1) } \\
\text { kW/ha }\end{array}$} & $\begin{array}{c}\text { 2) } \\
\text { kWh/ha }\end{array}$ & $\begin{array}{c}\text { 3) } \\
\text { kW/Func }\end{array}$ & $\begin{array}{c}\text { 4) } \\
\text { kWh/Func }\end{array}$ & \multicolumn{1}{c|}{$\begin{array}{c}\text { 5) } \\
\text { Func/ha }\end{array}$} \\
\hline Nerita flowers & 5,5 & 532,75 & 0,32 & 30,88 & 17 \\
Florexpo & 4,0 & 829,60 & 0,25 & 51,85 & 16 \\
MÉDIA & 4,8 & 681,18 & 0,28 & 41,37 & 17 \\
DESVIO & 0,8 & 148,43 & 0,03 & 10,48 & 1 \\
\hline
\end{tabular}


Tabela D.20: CULTIVO DE CRAVOS: SISTEMA DE IRRIGAÇÃO

\begin{tabular}{|c|c|c|c|c|c|c|c|c|c|c|}
\hline $\begin{array}{l}\text { AE DA } \\
\text { OINDÚSTRIA }\end{array}$ & $\begin{array}{l}\text { ÁREA } \\
\text { (ha) }\end{array}$ & $\begin{array}{c}\text { POTÉNCIA } \\
\text { INSTALADA } \\
(\mathrm{kW})\end{array}$ & $\begin{array}{c}\text { FATOR } \\
\text { COINCID } \\
(\%)\end{array}$ & $\begin{array}{c}\text { POTENCIA } \\
\text { COINCIDEN } \\
(\mathrm{kW})\end{array}$ & $\begin{array}{l}\text { HORAS } \\
\text { DIARIAS } \\
\text { (h) }\end{array}$ & $\begin{array}{c}\text { FATOR } \\
\text { UTILIZAÇÃO } \\
(\%)\end{array}$ & $\begin{array}{c}\text { ENERGIA } \\
\text { ANUAL } \\
\text { (kWh) }\end{array}$ & $\begin{array}{c}\text { POTENCIA } \\
\text { POR ha } \\
(\mathrm{kW} / \mathrm{ha})\end{array}$ & $\begin{array}{c}\text { ENERGIAVME } \\
\text { POR ha } \\
\text { (kWh/ha) }\end{array}$ & $\begin{array}{l}\text { PORCENT } \\
\text { DE USO }\end{array}$ \\
\hline ta flowers & 8,0 & 5,8 & 1 & 5,8 & 8 & 0,62 & 10.356 & 0,73 & 107,9 & $19,1 \%$ \\
\hline $\begin{array}{l}\text { expo } \\
\text { DIA }\end{array}$ & 5,0 & 5,2 & 1 & 5,2 & 8 & 0,62 & 9.285 & $\begin{array}{l}1,04 \\
0,88 \\
\end{array}$ & $\begin{array}{l}154,8 \\
131,3 \\
\end{array}$ & $\begin{array}{l}19,1 \% \\
19,1 \% \\
\end{array}$ \\
\hline
\end{tabular}

Tabela D.21: CULTIVO DE CRAVOS: CÂMARA DE REFRIGERAÇÃO

\begin{tabular}{|c|c|c|c|c|c|c|c|c|c|c|}
\hline $\begin{array}{l}\text { AE DA } \\
\text { OINDÚSTRIA }\end{array}$ & $\begin{array}{l}\text { ÁREA } \\
\text { (ha) }\end{array}$ & $\begin{array}{c}\text { POTÉNCIA } \\
\text { INSTALAD } \\
(\mathrm{kW})\end{array}$ & $\begin{array}{c}\text { VOLUME } \\
\text { CÂMARA } \\
(\mathrm{m} 3)\end{array}$ & $\begin{array}{l}\text { HORAS } \\
\text { DIÁRIAS } \\
\text { (h) }\end{array}$ & $\begin{array}{c}\text { FATOR } \\
\text { UTILIZAÇÄO } \\
(\%)\end{array}$ & $\begin{array}{c}\text { ENERGIA } \\
\text { ANUAL } \\
(\mathrm{kWh})\end{array}$ & $\begin{array}{l}\text { POTÊNCIA } \\
\text { POR ha } \\
\text { (kW/ha) }\end{array}$ & $\begin{array}{c}\text { ENERGIAMEES } \\
\text { POR ha } \\
\text { (kWh/ha) }\end{array}$ & $\begin{array}{l}\text { VOLUME } \\
\text { POR ha } \\
\text { (m3/ha) }\end{array}$ & $\begin{array}{c}\text { PORCENT } \\
\text { DE USO } \\
(\%)\end{array}$ \\
\hline flowers & 8,0 & 6,5 & 130,0 & 24 & 0,66 & 37.066 & 0,81 & 386,1 & 16,25 & $68,5 \%$ \\
\hline$m$ & 5,0 & 6,0 & 100,0 & 24 & 0,66 & 34.214 & $\begin{array}{l}1,20 \\
1,01\end{array}$ & $\begin{array}{l}570,2 \\
478,2\end{array}$ & $\begin{array}{r}20,00 \\
18,1\end{array}$ & $\begin{array}{l}70,6 \% \\
69,7 \%\end{array}$ \\
\hline
\end{tabular}

Tabela D.22: CULTIVO DE CRAVOS: ESCRITÓRIOS E SERVIÇOS GERAIS

\begin{tabular}{|c|c|c|c|c|c|c|c|c|}
\hline $\begin{array}{l}\text { ME DA } \\
\text { OINDÚSTRIA }\end{array}$ & $\begin{array}{l}\text { ÁREA } \\
\text { (ha) }\end{array}$ & $\begin{array}{l}\text { POTÊNCIA } \\
\text { INSTALADA } \\
(\mathrm{kW})\end{array}$ & $\begin{array}{c}\text { HORAS } \\
\text { DIÁRIAS } \\
\text { (h) }\end{array}$ & $\begin{array}{c}\text { FATOR } \\
\text { UTILIZAÇÃO } \\
(\%)\end{array}$ & $\begin{array}{c}\text { ENERGIA } \\
\text { ANUAL } \\
\text { (kWh) }\end{array}$ & $\begin{array}{l}\text { POTÊNCIA } \\
\text { POR ha } \\
\text { (kW/ha) }\end{array}$ & $\begin{array}{c}\text { ENERGIAIMÊS } \\
\text { POR ha } \\
\text { (kWh/ha) }\end{array}$ & $\begin{array}{c}\text { PORCENTAG } \\
\text { DE USO } \\
(\%)\end{array}$ \\
\hline ta flowers & 8,0 & 2,5 & 16 & 0,5 & 6.720 & 0,31 & 70,0 & $12,4 \%$ \\
\hline $\begin{array}{l}\text { expo } \\
\text { DIA }\end{array}$ & 5,0 & 2,0 & 16 & 0,5 & 4.992 & $\begin{array}{l}0,40 \\
0,36\end{array}$ & $\begin{array}{l}83,2 \\
76,6\end{array}$ & $\begin{array}{l}10,3 \% \\
11,2 \%\end{array}$ \\
\hline
\end{tabular}


Tabela D.23: CULTIVO DE CRAVOS: COMPARAÇÃO DE ENERGIA CALCULADA COM A ENERGIA MÉDIA MENSAL REGISTRADA NA EMELNORTE

\begin{tabular}{|c|c|c|c|c|c|}
\hline $\begin{array}{l}\text { NOME DA } \\
\text { AGROINDÚSTRIA }\end{array}$ & $\begin{array}{l}\text { ENERGIA } \\
\text { CALCULAD } \\
\text { POR ha } \\
(\mathrm{kWh} / \mathrm{ha})\end{array}$ & $\begin{array}{c}\text { ENERGIA } \\
\text { CALCULAD } \\
\text { TOTAL } \\
\text { (kWh) }\end{array}$ & $\begin{array}{r}\text { ENERGIA } \\
\text { MÉDIA } \\
\text { MEDIDA } \\
(\mathrm{kWh})\end{array}$ & DIFERENÇA & $\begin{array}{c}\text { PORCENTAG } \\
\text { DE ERRO } \\
(\%) \\
\end{array}$ \\
\hline Nerita flowers & 564 & 4.512 & 4.262 & $-249,8$ & $-5,9 \%$ \\
\hline Florexpo & 808 & 4.041 & 4.148 & 107,0 & $2,6 \%$ \\
\hline
\end{tabular}

Tabela D.24: CULTIVO DE CRAVOS: COMPARAÇÃO DE POTÊNCIA CALCULADA COM A POTÊNCIA CONTRATADA

\begin{tabular}{|l|r|r|r|r|r|}
\hline NOME DA & $\begin{array}{c}\text { POTÉNCIA } \\
\text { AGROINDÚSTRIA } \\
\text { CALCULAD } \\
\text { POR ha } \\
(\mathrm{kW} / \mathrm{ha})\end{array}$ & $\begin{array}{c}\text { POTÊNCIA } \\
\text { INSTALADA } \\
\text { TOTAL } \\
(\mathrm{kW})\end{array}$ & $\begin{array}{c}\text { POTÊNCIA } \\
\text { CONTRAT }\end{array}$ & DIFERENÇA & $\begin{array}{c}\text { PORCENT } \\
\text { DE ERRO }\end{array}$ \\
\hline Nerita flowers & 1,85 & 15 & 44 & $(\mathrm{~kW})$ & \multicolumn{1}{c|}{$(\%)$} \\
Florexpo & 2,64 & 13 & 20 & 6,2 & $66,4 \%$ \\
\hline
\end{tabular}


Tabela D.25: CULTIVO DE VÁRIAS ESPÉCIES: DADOS GERAIS

\begin{tabular}{|c|c|c|c|c|c|c|c|}
\hline \multirow{2}{*}{$\begin{array}{l}\text { NOME DA } \\
\text { AGROINDÚSTRIA }\end{array}$} & \multicolumn{3}{|c|}{ ÁREA POR TIPO DE CULTIVO } & \multicolumn{2}{|c|}{ NÚMERO FUNCIONARIOS } & \multirow{2}{*}{$\begin{array}{r}\text { POTÉNCIA } \\
\text { CONTRATADA } \\
(\mathrm{kW})\end{array}$} & \multirow{2}{*}{$\begin{array}{c}\text { ENERGIA } \\
\text { MÉDIA } \\
\text { (kWh/mes) }\end{array}$} \\
\hline & $\begin{array}{c}\text { ROSAS } \\
\text { (ha) }\end{array}$ & $\begin{array}{l}\text { GYPSOFILA } \\
\text { (ha) }\end{array}$ & $\begin{array}{l}\text { OUTRAS } \\
\text { (ha) }\end{array}$ & TECNICO & PRODUÇÃO & & \\
\hline Jardines del Cayambe & 2,0 & 6,0 & & 14 & 126 & 174 & 34.342 \\
\hline Inlandes & 12,5 & 0,5 & & 20 & 170 & 170 & 33.840 \\
\hline Gerflores & 9,0 & 0,3 & & 12 & 120 & 65 & 26.888 \\
\hline Denmar & 6,0 & 2,0 & & 16 & 122 & 172 & 45.589 \\
\hline Ecuarosas & 8,0 & 2,0 & & 14 & 162 & 272 & 26.219 \\
\hline Inagro & 1,0 & 6,0 & 0,5 & 18 & 124 & 408 & 53.013 \\
\hline Floremit & & 8,5 & 5,5 & 26 & 214 & 450 & 166.557 \\
\hline Inflorex & & 6,0 & 5,0 & 18 & 152 & 253 & 58.688 \\
\hline Guala impor & 3,0 & & 1,0 & 10 & 55 & 33 & 11.173 \\
\hline Roger Chiriboga & & & 4,0 & 8 & 42 & 45 & 4.022 \\
\hline
\end{tabular}

Fonte: Usos finais nas agroindustrias. Ibarra Janeiro 1994

Tabela D.26: CULTIVO DE VÁRIAS ESPÉCIES: CALCULO DE POTÊNCIA CONTRATADA E ENERGIA MÉDIA MENSAL POR HECTARE E POR FUNCIONÁRIO

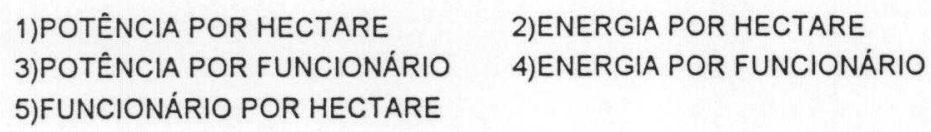

\begin{tabular}{|l|r|r|r|r|r|}
\hline NOME DA & \multicolumn{1}{c|}{$\begin{array}{c}\text { 1) } \\
\text { kW/ha }\end{array}$} & $\begin{array}{c}\text { 2) } \\
\text { kWh/ha }\end{array}$ & $\begin{array}{c}\text { 3) } \\
\text { kW/Func }\end{array}$ & $\begin{array}{c}\text { 4) } \\
\text { kWh/Func }\end{array}$ & $\begin{array}{c}\text { 5) } \\
\text { Func/ha }\end{array}$ \\
\hline Jardines del Cayambe & 21,75 & 4.293 & 1,24 & 245,30 & 18 \\
Inlandes & 13,08 & 2.603 & 0,89 & 178,11 & 15 \\
Gerflores & 6,99 & 2.891 & 0,49 & 203,70 & 14 \\
Denmar & 21,50 & 5.699 & 1,25 & 330,36 & 17 \\
Ecuarosas & 27,20 & 2.622 & 1,55 & 148,97 & 18 \\
Inagro & 54,40 & 7.068 & 2,87 & 373,33 & 19 \\
Floremit & 32,14 & 11.897 & 1,88 & 693,99 & 17 \\
Inflorex & 23,00 & 5.335 & 1,49 & 345,22 & 15 \\
Guala impor & 8,25 & 2.793 & 0,51 & 171,89 & 16 \\
Roger Chiriboga & 11,25 & 1.006 & 0,90 & 80,44 & 13 \\
\multicolumn{1}{r|}{ MÉDIA } & 21,96 & 4.621 & 1,31 & 277,13 & 16 \\
\multicolumn{1}{|c|}{ DESVIO } & 13,38 & 2.970 & 0,67 & 165,19 & 2 \\
\hline
\end{tabular}


Tabela D.27: CULTIVO DE VÁRIAS ESPÉCIES: ILUMINAÇÃO DO CULTIVO

COM LÂMPADAS INCANDESCENTES

\begin{tabular}{|c|c|c|c|c|c|c|c|c|c|c|}
\hline $\begin{array}{l}\text { NOME DA } \\
\text { AGROINDÚSTRIA }\end{array}$ & $\begin{array}{l}\text { ÁREA } \\
\text { (ha) }\end{array}$ & $\begin{array}{c}\text { POTÉNCIA } \\
\text { INSTALADA } \\
(\mathrm{kW}) \\
\end{array}$ & $\begin{array}{c}\text { FATOR } \\
\text { COINCID } \\
(\%) \\
\end{array}$ & $\begin{array}{c}\text { POTÉNCIA } \\
\text { COINCIDEN } \\
(\mathrm{kW}) \\
\end{array}$ & $\begin{array}{c}\text { HORAS } \\
\text { DIÁRIAS } \\
(h)\end{array}$ & $\begin{array}{c}\text { FATOR } \\
\text { UTILIZAÇÃO } \\
(\%) \\
\end{array}$ & $\begin{array}{c}\text { ENERGIA } \\
\text { ANUAL } \\
\text { (kWh) }\end{array}$ & $\begin{array}{l}\text { POTÉNCIA } \\
\text { POR ha } \\
\text { (kW/ha) }\end{array}$ & $\begin{array}{c}\text { ENERG/MÉS } \\
\begin{array}{c}\text { POR ha } \\
(\mathrm{kW} / \mathrm{ha})\end{array}\end{array}$ & $\begin{array}{c}\text { PORCENT } \\
\text { DE USO } \\
(\%) \\
\end{array}$ \\
\hline Jardines del Cayambe & 6,0 & 510,0 & 0,25 & 127,5 & 10 & 0,70 & 281.138 & 85,00 & 3.905 & $64,4 \%$ \\
\hline Inlandes & 0,5 & 48,0 & 0,33 & 15,8 & 12 & 0,84 & 57.480 & 96,00 & 9.580 & $14,3 \%$ \\
\hline Gerflores & 0,3 & 26,0 & 1,00 & 26,0 & 8 & 0,50 & 23.400 & 86,67 & 6.500 & $7,9 \%$ \\
\hline Denmar & 2,0 & 187,0 & 0,33 & 61,7 & 8 & 0,75 & 133.294 & 93,50 & 5.554 & $23,5 \%$ \\
\hline Ecuarosas & 2,0 & 214,0 & 0,25 & 53,5 & 7 & 0,72 & 97.070 & 107,00 & 4.045 & $30,4 \%$ \\
\hline Inagro & 6,0 & 516,0 & 0,25 & 129,0 & 12 & 0,83 & 308.362 & 86,00 & 4.283 & $47,2 \%$ \\
\hline Floremit & 8,5 & 895,0 & 0,33 & 295,4 & 11 & 0,73 & 853.798 & 105,29 & 8.371 & $43,2 \%$ \\
\hline Inflorex & 6,0 & 480,0 & 0,25 & 120,0 & 12 & 1,00 & 518.400 & 80,00 & 7.200 & $67,6 \%$ \\
\hline Guala impor & 0,0 & & & 0,0 & & & 0 & & & \\
\hline Roger Chiriboga & 0,0 & & & 0,0 & & & 0 & & & \\
\hline MÉDIA & & & 0,37 & & 10 & 0,76 & & 92,43 & 6.180 & $55,0 \%$ \\
\hline DESVIO & & & & & 2 & 0 & & 9,19 & 1.976 & \\
\hline
\end{tabular}

COM LÂMPADAS A VAPOR DE SÓDIO

\begin{tabular}{|c|c|c|c|c|c|c|c|c|c|c|}
\hline $\begin{array}{l}\text { NOME DA } \\
\text { AGROINDÚSTRIA }\end{array}$ & $\begin{array}{l}\text { ÁREA } \\
\text { (ha) }\end{array}$ & 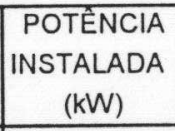 & $\begin{array}{c}\text { FATOR } \\
\text { COINCID } \\
(\%)\end{array}$ & $\begin{array}{c}\text { POTÉNCIA } \\
\text { COINCIDEN } \\
(\mathrm{kW})\end{array}$ & $\begin{array}{c}\text { HORAS } \\
\text { DIÁRIAS } \\
\text { (h) }\end{array}$ & $\begin{array}{c}\text { FATOR } \\
\text { UTILIZAÇÃO } \\
(\%) \\
\end{array}$ & $\begin{array}{c}\text { ENERGIA } \\
\text { ANUAL } \\
\text { (kWh) }\end{array}$ & $\begin{array}{l}\text { POTÉNCIA } \\
\text { POR ha } \\
\text { (kW/ha) }\end{array}$ & $\begin{array}{c}\text { ENERG/MES } \\
\text { POR ha } \\
(\mathrm{kWh} / \mathrm{ha}) \\
\end{array}$ & $\begin{array}{c}\text { PORCENT } \\
\text { DE USO } \\
(\%) \\
\end{array}$ \\
\hline \begin{tabular}{|l|} 
Jardines del Cayambe \\
Inlandes \\
Gerflores \\
Denmar \\
Ecuarosas \\
Inagro \\
Floremit \\
Inflorex \\
Guala impor \\
Roger Chiriboga \\
\end{tabular} & $\begin{array}{l}6,0 \\
0,5 \\
0,3 \\
2,0 \\
2,0 \\
6,0 \\
8,5 \\
6,0\end{array}$ & & & & & & $\begin{array}{l}0 \\
0 \\
0 \\
0 \\
0 \\
0 \\
0 \\
0 \\
0 \\
0\end{array}$ & $\begin{array}{l}0 \\
0 \\
0 \\
0 \\
0 \\
0 \\
0 \\
0 \\
0 \\
0\end{array}$ & $\begin{array}{l}0 \\
0 \\
0 \\
0 \\
0 \\
0 \\
0 \\
0 \\
0 \\
0\end{array}$ & \\
\hline
\end{tabular}


Tabela D.28: CULTIVO DE VÁRIAS ESPÉCIES: ILUMINAÇÃO NA SALA DE ABERTURA

COM LAMMPADAS INCANDESCENTES

\begin{tabular}{|c|c|c|c|c|c|c|c|c|c|c|}
\hline $\begin{array}{l}\text { NOME DA } \\
\text { AGROINDÚSTRIA }\end{array}$ & $\begin{array}{l}\text { ÁREA } \\
\text { (ha) }\end{array}$ & $\begin{array}{c}\text { POTÉNCIA } \\
\text { INSTALADA } \\
(\mathrm{kW})\end{array}$ & $\begin{array}{c}\text { FATOR } \\
\text { COINCID } \\
(\%)\end{array}$ & $\begin{array}{c}\text { POTÉNCIA } \\
\text { COINCIDEN } \\
(\mathrm{kW})\end{array}$ & $\begin{array}{c}\text { HORAS } \\
\text { DIÁRIAS } \\
\text { (h) }\end{array}$ & $\begin{array}{c}\text { FATOR } \\
\text { UTILIZAÇÃO } \\
(\%)\end{array}$ & $\begin{array}{c}\text { ENERGIA } \\
\text { ANUAL } \\
(\mathrm{kWh})\end{array}$ & $\begin{array}{l}\text { POTÉNCIA } \\
\text { POR ha } \\
\text { (kW/ha) }\end{array}$ & $\begin{array}{r}\text { ENER/MÉS } \\
\text { POR ha } \\
(\mathrm{kWh} / \mathrm{ha})\end{array}$ & $\begin{array}{c}\text { PORCENTA } \\
\text { DE USO } \\
(\%)\end{array}$ \\
\hline Jardines del Cayambe & 6,0 & 14,0 & 0,33 & 4,6 & 24 & 1 & 34.927 & 2,33 & 485 & $8,0 \%$ \\
\hline Inlandes & 0,5 & 4,2 & 0,5 & 2,1 & 24 & 1 & 15.876 & 8,40 & 2.646 & $4,0 \%$ \\
\hline Gerflores & 0,3 & 4,0 & 0,5 & 2,0 & 15 & 1 & 9.450 & 13,33 & 2.625 & $3,2 \%$ \\
\hline Denmar & 2,0 & 10,0 & 0,5 & 5,0 & 24 & 1 & 37.800 & 5,00 & 1.575 & $6,7 \%$ \\
\hline Ecuarosas & 2,0 & 9,6 & 0,5 & 4,8 & 18 & 1 & 27.216 & 4,80 & 1.134 & $8,5 \%$ \\
\hline Inagro & 6,0 & 7,2 & 0,5 & 3,6 & 15 & 1 & 17.010 & 1,20 & 236 & $2,6 \%$ \\
\hline Floremit & 8,5 & 20,0 & 0,5 & 10,0 & 24 & 1 & 75.600 & 2,35 & 741 & $3,8 \%$ \\
\hline Inflorex & 6,0 & & & & & & 0 & 0,00 & 0 & $0,0 \%$ \\
\hline Guala impor & & & & & & & 0 & & & $0,0 \%$ \\
\hline Roger Chiriboga & & & & & & & & & & \\
\hline MÉDIA & & & & & 21 & & & 5,35 & 1.349 & $10,5 \%$ \\
\hline DESVIAÇÃO & & & & & 4 & & & 3,94 & 907 & \\
\hline
\end{tabular}

COM LÂMPADAS A VAPOR DE SÓDIO

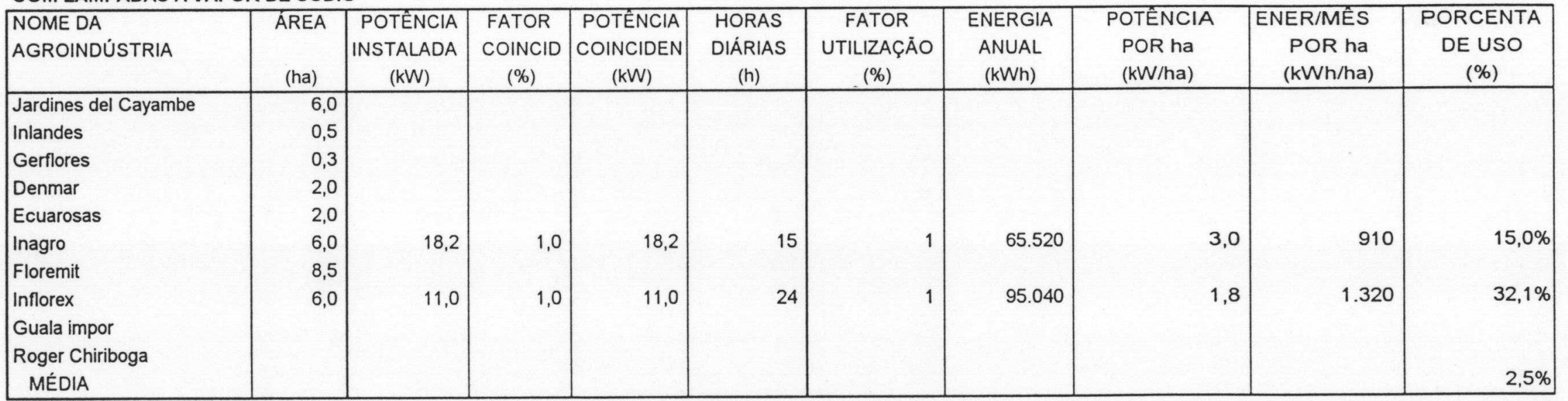


Tabela D.29: CULTIVO DE VÁRIAS ESPÉCIES: SUBLIMADORES

\begin{tabular}{|c|c|c|c|c|c|c|c|c|}
\hline $\begin{array}{l}\text { NOME DA } \\
\text { AGROINDÚSTRIA }\end{array}$ & $\begin{array}{l}\text { ÁREA } \\
\text { (ha) }\end{array}$ & $\begin{array}{c}\text { POTÉNCIA } \\
\text { INSTALAD } \\
(\mathrm{kW})\end{array}$ & $\begin{array}{c}\text { HORAS } \\
\text { DIÁRIAS } \\
\text { (h) }\end{array}$ & $\begin{array}{c}\text { FATOR } \\
\text { UTILIZAÇÁA } \\
(\%)\end{array}$ & $\begin{array}{c}\text { ENERGIA } \\
\text { ANUAL } \\
\text { (kWh) }\end{array}$ & $\begin{array}{l}\text { POTÉNCIA } \\
\text { POR ha } \\
\text { (kW/ha) }\end{array}$ & $\begin{array}{c}\text { ENERG/MESS } \\
\text { POR ha } \\
\text { (kWh/ha) }\end{array}$ & $\begin{array}{c}\text { PORCENTA } \\
\text { DE USO } \\
(\%)\end{array}$ \\
\hline Jardines del Cayambe & 2,0 & & & & & & & \\
\hline Inlandes & 12,5 & 95,0 & 6 & 1 & 205.200 & 7,60 & 1.368 & $47,0 \%$ \\
\hline Gerflores & 9,0 & 85,0 & 4 & 1 & 122.400 & 9,44 & 1.133 & $30,6 \%$ \\
\hline Denmar & 6,0 & 54,0 & 11 & 1 & 213.840 & 9,00 & 2.970 & $72,1 \%$ \\
\hline Ecuarosas & 8,0 & 56,0 & 4 & 1 & 80.640 & 7,00 & 840 & $14,2 \%$ \\
\hline Inagro & 1,0 & 5,5 & 12 & 1 & 23.760 & 5,50 & 1.980 & $7,4 \%$ \\
\hline Floremit & 0,0 & & & & & & & $0,0 \%$ \\
\hline Inflorex & 0,0 & & & & & & & $0,0 \%$ \\
\hline Guala impor & 3,0 & 19,2 & 6 & 1 & 41.472 & 6,40 & 1.152 & $5,4 \%$ \\
\hline Roger Chiriboga & 0,0 & & & & 0 & & & $0,0 \%$ \\
\hline MÉDIA & & & 7 & & & 7,49 & 1.574 & $10,5 \%$ \\
\hline DESVIO & & & 3 & & & 1,38 & 715 & \\
\hline
\end{tabular}


Tabela D.30: CULTIVO DE VÁRIAS ESPÉCIES: SISTEMAS DE IRRIGAÇÃO

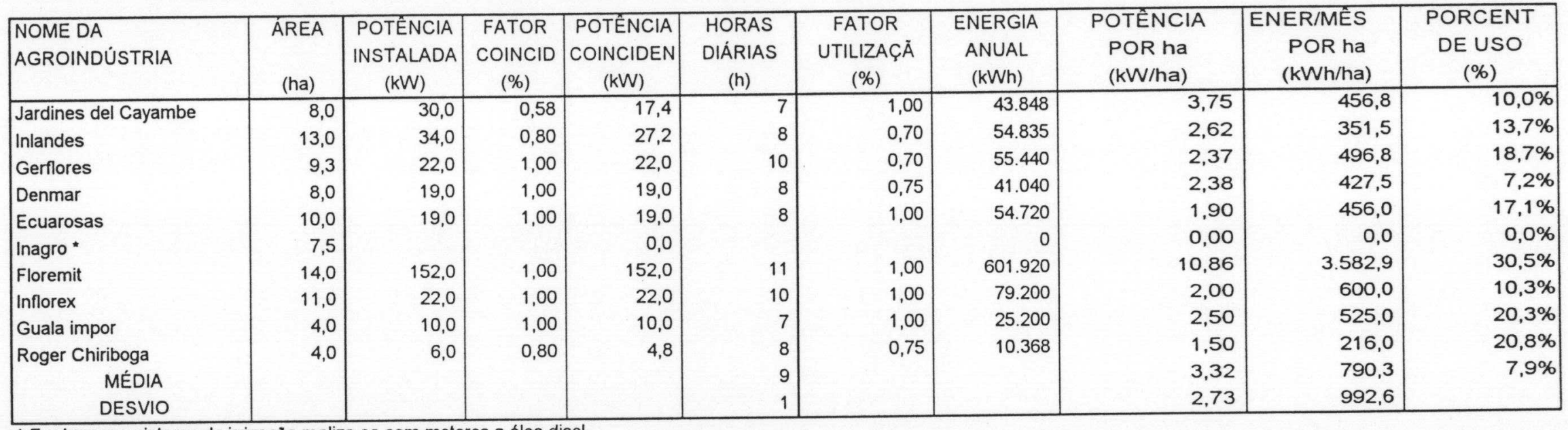

- Em Inagro o sistema de irrigaçåo realiza-se com motores a óleo disel 
Tabela D.31: CULTIVO DE VÁRIAS ESPÉCIES: CÂMARA DE REFRIGERAÇĀO

\begin{tabular}{|c|c|c|c|c|c|c|c|c|c|c|}
\hline $\begin{array}{l}\text { NOME DA } \\
\text { AGROINDÚSTRIA }\end{array}$ & $\begin{array}{l}\text { ÁREA } \\
\text { (ha) }\end{array}$ & $\begin{array}{c}\text { POTÊNCIA } \\
\text { INSTALADA } \\
(\mathrm{kW}) \\
\end{array}$ & $\begin{array}{c}\text { VOLUME } \\
\text { CÂMAR } \\
(\mathrm{m} 3) \\
\end{array}$ & $\begin{array}{c}\text { HORAS } \\
\text { DIÁRIAS } \\
\text { (h) }\end{array}$ & $\begin{array}{c}\text { FATOR } \\
\text { UTILIZAÇÃ } \\
(\%)\end{array}$ & $\begin{array}{c}\text { ENERGIA } \\
\text { ANUAL } \\
\text { (kWh) } \\
\end{array}$ & $\begin{array}{l}\text { POTÉNCIA } \\
\text { POR ha } \\
\text { (kW/ha) }\end{array}$ & $\begin{array}{c}\text { ENERGIA/MẾS } \\
\text { POR ha } \\
\text { (kWh/ha) }\end{array}$ & $\begin{array}{l}\text { VOLUME } \\
\text { POR ha } \\
\text { (m3/ha) }\end{array}$ & $\begin{array}{c}\text { PORCENTA } \\
\text { DE USO } \\
(\%) \\
\end{array}$ \\
\hline Jardines del Cayambe & 8,0 & 10,8 & 500 & 24 & 0,66 & 61.586 & 1,35 & 642 & 62,5 & $14,1 \%$ \\
\hline Inlandes & 13,0 & 8,4 & 500 & 24 & 0,66 & 47.900 & 0,65 & 307 & 38,5 & $12,0 \%$ \\
\hline Gerflores & 9,3 & 11,2 & 210 & 24 & 0,66 & 63.981 & 1,21 & 573 & 22,6 & $21,6 \%$ \\
\hline Denmar & 8,0 & 17,4 & 450 & 24 & 0,66 & 99.222 & 2,18 & 1.034 & 56,3 & $17,5 \%$ \\
\hline Ecuarosas & 10,0 & 7,0 & 300 & 24 & 0,66 & 39.917 & 0,70 & 333 & 30,0 & $12,5 \%$ \\
\hline Inagro & 7,5 & 32,0 & 220 & 24 & 0,66 & 182.477 & 4,27 & 2.028 & 29,3 & $28,0 \%$ \\
\hline Floremit & 14,0 & 60,0 & 660 & 24 & 0,66 & 342.144 & 4,29 & 2.037 & 47,1 & $17,3 \%$ \\
\hline Inflorex & 11,0 & 10,0 & 280 & 24 & 0,66 & 57.024 & 0,91 & 432 & 25,5 & $7,4 \%$ \\
\hline Guala impor & 4,0 & 7,7 & 320 & 24 & 0,66 & 43.908 & 1,93 & 915 & 80,0 & $35,4 \%$ \\
\hline Roger Chiriboga & 4,0 & 6,0 & 240 & 24 & 0,66 & 34.214 & 1,50 & 713 & 60,0 & $68,5 \%$ \\
\hline MÉDIA & & & & & & & 1,90 & 901 & 45,2 & $10,0 \%$ \\
\hline DESVIO & & & & & & & 1,28 & 607 & 18,1 & \\
\hline
\end{tabular}


Tabela D.32: CULTIVO DE VÁRIAS ESPÉCIES: ESCRITÓRIOS E SERVIÇOS GERAIS

\begin{tabular}{|c|c|c|c|c|c|c|c|c|}
\hline $\begin{array}{l}\text { NOME DA } \\
\text { AGROINDÚSTRIA }\end{array}$ & $\begin{array}{l}\text { ÁREA } \\
\text { (ha) }\end{array}$ & $\begin{array}{c}\text { POTENCIA } \\
\text { INSTALAD } \\
(\mathrm{kW})\end{array}$ & $\begin{array}{c}\text { HORAS } \\
\text { DIÁRIAS } \\
(h)\end{array}$ & $\begin{array}{c}\text { FATOR } \\
\text { UTILIZAÇÃ } \\
(\%) \\
\end{array}$ & $\begin{array}{c}\text { ENERGIA } \\
\text { ANUAL } \\
(\mathrm{kWh})\end{array}$ & $\begin{array}{c}\text { POTÉNCIA } \\
\text { POR ha } \\
\text { (kW/ha) }\end{array}$ & $\begin{array}{c}\text { ENERG/MÊS } \\
\text { POR ha } \\
\text { (kWh/ha) }\end{array}$ & $\begin{array}{c}\text { PORCENT } \\
\text { DE USO } \\
(\%) \\
\end{array}$ \\
\hline Jardines del Cayambe & 8,0 & 5,0 & 18 & 0,50 & 15.120 & 0,63 & 157,5 & $3,5 \%$ \\
\hline Inlandes & 13,0 & 6,0 & 24 & 0,40 & 19.354 & 0,46 & 124,1 & $4,8 \%$ \\
\hline Gerflores & 9,3 & 6,0 & 24 & 0,45 & 21.773 & 0,65 & 195,1 & $7,3 \%$ \\
\hline Denmar & 8,0 & 9,0 & 14 & 1,00 & 42.336 & 1,13 & 441,0 & $7,5 \%$ \\
\hline Ecuarosas & 10,0 & 5,0 & 12 & 1,00 & 20.160 & 0,50 & 168,0 & $6,3 \%$ \\
\hline Inagro & 7,5 & 4,0 & 24 & 0,42 & 13.548 & 0,53 & 150,5 & $2,1 \%$ \\
\hline Floremit & 14,0 & 12,0 & 12 & 0,67 & 32.417 & 0,86 & 193,0 & $1,6 \%$ \\
\hline Inflorex & 11,0 & 5,0 & 10 & 1,00 & 16.800 & 0,45 & 127,3 & $2,2 \%$ \\
\hline Guala impor & 4,0 & 4,0 & 10 & 1,00 & 13.440 & 1,00 & 280,0 & $10,8 \%$ \\
\hline Roger Chiriboga & 4,0 & 2,0 & 8 & 1,00 & 5.376 & 0,50 & 112,0 & $10,8 \%$ \\
\hline MÉDIA & & & & & & 0,67 & 194,8 & $2,2 \%$ \\
\hline DESVIO & & & & & & 0,23 & 94,0 & \\
\hline
\end{tabular}

Tabela D.33: CULTIVO DE VÁRIAS ESPÉCIES: RESISTÊNCIAS

\begin{tabular}{|c|c|c|c|c|c|c|c|c|}
\hline $\begin{array}{l}\text { NOME DA } \\
\text { AGROINDÚSTRIA }\end{array}$ & $\begin{array}{l}\text { ÁREA } \\
\text { (ha) }\end{array}$ & $\begin{array}{c}\text { POTÊNCIA } \\
\text { INSTALADA } \\
(\mathrm{kW})\end{array}$ & $\begin{array}{c}\text { HORAS } \\
\text { DIÁRIAS } \\
(\mathrm{h}) \\
\end{array}$ & $\begin{array}{c}\text { FATOR } \\
\text { UTILIZAÇÄA } \\
(\%) \\
\end{array}$ & $\begin{array}{c}\text { ENERGIA } \\
\text { ANUAL } \\
(\mathrm{kWh}) \\
\end{array}$ & $\begin{array}{l}\text { POTENCIA } \\
\text { POR ha } \\
\text { (kW/ha) }\end{array}$ & $\begin{array}{c}\text { ENERG/MÉS } \\
\text { POR ha } \\
\text { (kWh/ha) } \\
\end{array}$ & $\begin{array}{c}\text { PORCENTAG } \\
\text { DE USO } \\
(\%) \\
\end{array}$ \\
\hline $\begin{array}{l}\text { Jardines del Cayambe } \\
\text { Inlandes } \\
\text { Gerflores } \\
\text { Denmar } \\
\text { Ecuarosas } \\
\text { Inagro } \\
\text { Floremit } \\
\text { Inflorex } \\
\text { Guala impor } \\
\text { Roger Chiriboga } \\
\text { MÉDIA }\end{array}$ & $\begin{array}{l}6,0 \\
0,5 \\
0,3 \\
2,0 \\
2,0 \\
6,0 \\
8,5 \\
6,0\end{array}$ & $\begin{array}{l}7,8 \\
9,2\end{array}$ & $\begin{array}{l}15 \\
24\end{array}$ & $\begin{array}{l}1 \\
1\end{array}$ & $\begin{array}{r}0 \\
0 \\
0 \\
0 \\
0 \\
42.120 \\
68.890 \\
0 \\
0 \\
0\end{array}$ & $\begin{array}{l}0,00 \\
0,00 \\
0,00 \\
0,00 \\
0,00 \\
1,30 \\
1,08\end{array}$ & $\begin{array}{r}0 \\
0 \\
0 \\
0 \\
0 \\
585 \\
675\end{array}$ & $\begin{array}{r}9,6 \% \\
17,2 \% \\
\\
1,4 \% \\
\end{array}$ \\
\hline
\end{tabular}


Tabela D.34: CULTIVO DE VÁRIAS ESPÉCIES: COMPARAÇÃO DE ENERGIA CALCULADA COM ENERGIA MÉDIA MENSAL REGISTRADA NA EMELNORTE

\begin{tabular}{|c|c|c|c|c|c|}
\hline $\begin{array}{l}\text { NOME DA } \\
\text { AGROINDÚSTRIA }\end{array}$ & \begin{tabular}{|l|} 
ENERGIA \\
CALCULA \\
POR ha \\
(kWh/ha)
\end{tabular} & \begin{tabular}{|c|} 
ENERGIA \\
CALCULADA \\
TOTAL \\
$(\mathrm{kWh})$ \\
\end{tabular} & $\begin{array}{c}\text { ENERGIA } \\
\text { MÉDIA } \\
\text { MEDIDA } \\
\text { (kWh) }\end{array}$ & DIFEREN & $\begin{array}{c}\text { PORCENT } \\
\text { DE ERRO } \\
(\%)\end{array}$ \\
\hline Jardines del Cayambe & 5.646 & 36.385 & 34.342 & $(2.043)$ & $-5,95 \%$ \\
\hline Inlandes & 14.377 & 33.387 & 33.840 & 453 & $1,34 \%$ \\
\hline Gerflores & 11.524 & 24.704 & 26.888 & 2.184 & $8,12 \%$ \\
\hline Denmar & 12.001 & 47.294 & 45.589 & $(1.705)$ & $-3,74 \%$ \\
\hline Ecuarosas & 6.975 & 26.644 & 26.219 & (425) & $-1,62 \%$ \\
\hline Inagro & 10.172 & 54.400 & 53.013 & $(1.387)$ & $-2,62 \%$ \\
\hline Floremit & 15.600 & 164.564 & 166.557 & 1.993 & $1,20 \%$ \\
\hline Inflorex & 9.679 & 63.872 & 58.688 & $(5.184)$ & $-8,83 \%$ \\
\hline Guala impor & 2.872 & 10.335 & 11.173 & 838 & $7,50 \%$ \\
\hline Roger Chiriboga & 1.041 & 4.163 & 4.022 & (141) & $-3,51 \%$ \\
\hline
\end{tabular}

Tabela D.35: CULTIVO DE VÁRIAS ESPÉCIES: COMPARAÇÃO DE POTÊNCIA CALCULADA COM A POTÊNCIA CONTRATADA

\begin{tabular}{|c|c|c|c|c|c|}
\hline $\begin{array}{l}\text { NOME DA } \\
\text { AGROINDÚSTRIA }\end{array}$ & $\begin{array}{l}\text { POTÉNCI } \\
\text { CALCULA } \\
\text { POR ha } \\
\text { (kW/ha) }\end{array}$ & $\begin{array}{c}\text { POTÉNCIA } \\
\text { INSTALAD } \\
\text { TOTAL } \\
(\mathrm{kW})\end{array}$ & $\begin{array}{c}\text { POTÉNCI } \\
\text { CONTRAT } \\
(\mathrm{kW})\end{array}$ & DIFEREN & $\begin{array}{c}\text { PORCENT } \\
\text { DE USO } \\
(\%)\end{array}$ \\
\hline \begin{tabular}{|l} 
Jardines del Cayambe \\
\end{tabular} & 93,1 & 570 & 174 & -396 & $-227,5 \%$ \\
\hline Inlandes & 115,7 & 196 & 170 & -26 & $-15,1 \%$ \\
\hline Gerflores & 113,7 & 154 & 65 & -89 & $-137,3 \%$ \\
\hline Denmar & 113,2 & 296 & 172 & -124 & $-72,3 \%$ \\
\hline Ecuarosas & 121,9 & 311 & 272 & -39 & $-14,2 \%$ \\
\hline Inagro & 98,8 & 591 & 408 & -183 & $-44,8 \%$ \\
\hline Floremit & 124,7 & 1148 & 450 & -698 & $-155,2 \%$ \\
\hline Inflorex & 83,4 & 528 & 253 & -275 & $-108,7 \%$ \\
\hline Guala impor & 11,8 & 41 & 33 & -8 & $-23,9 \%$ \\
\hline Roger Chiriboga & 3,5 & 14 & 45 & 31 & $68,9 \%$ \\
\hline
\end{tabular}


ANEXO E: FOTOGRAFIAS

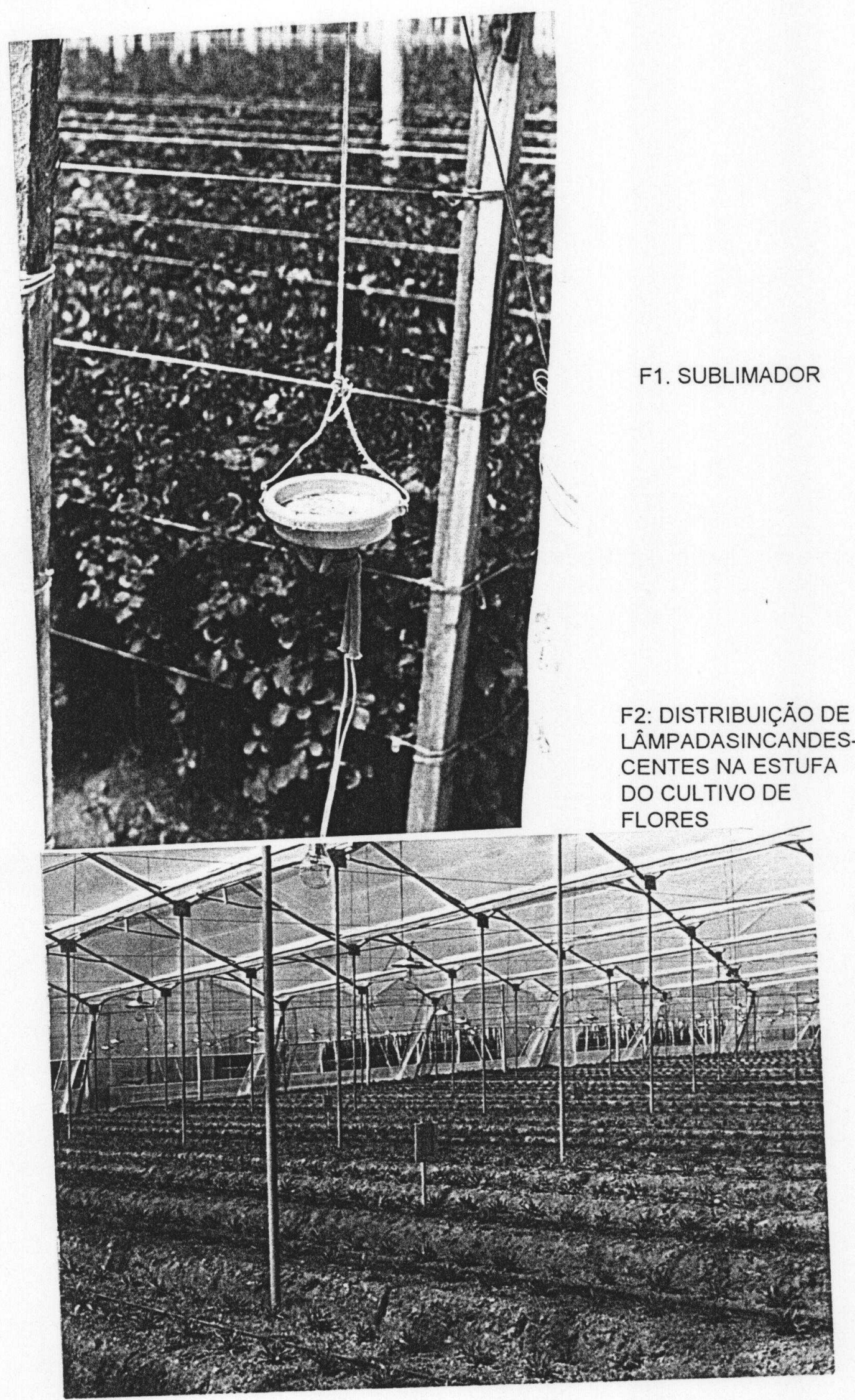




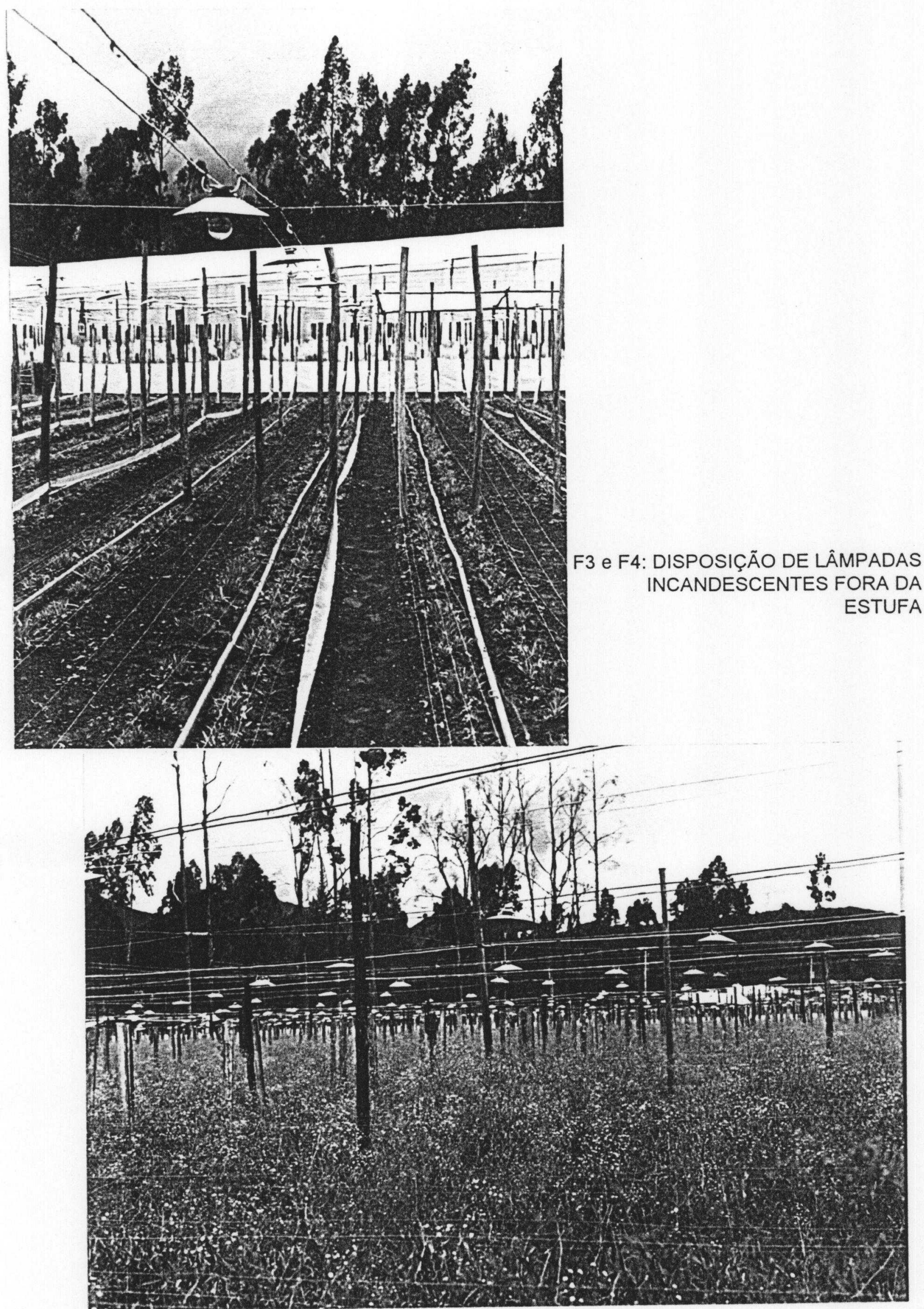




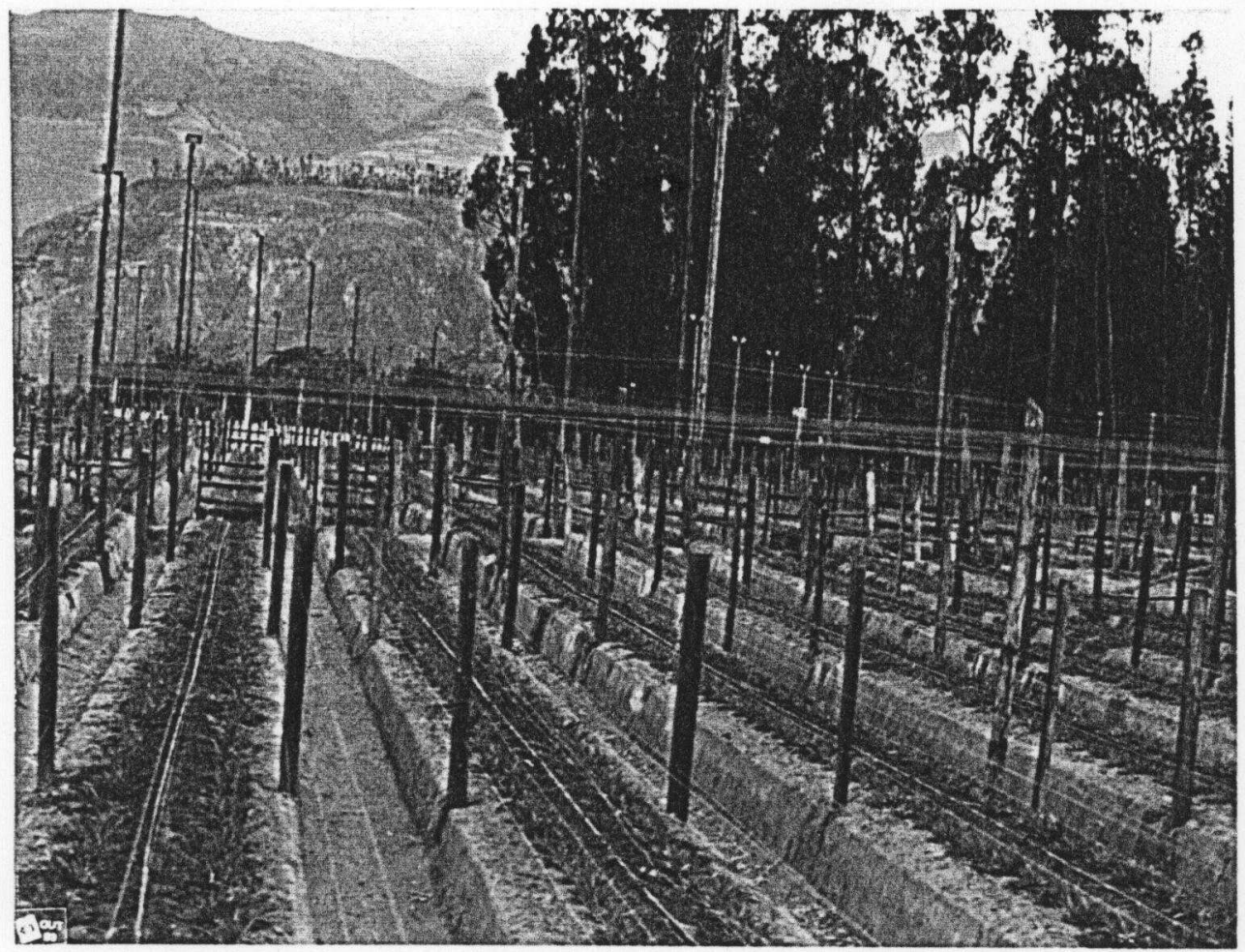

F5 e F6: DISPOSIÇÃO DE LÂMPADAS A VAPOR DE SÓDIO FORA DA ESTUFA

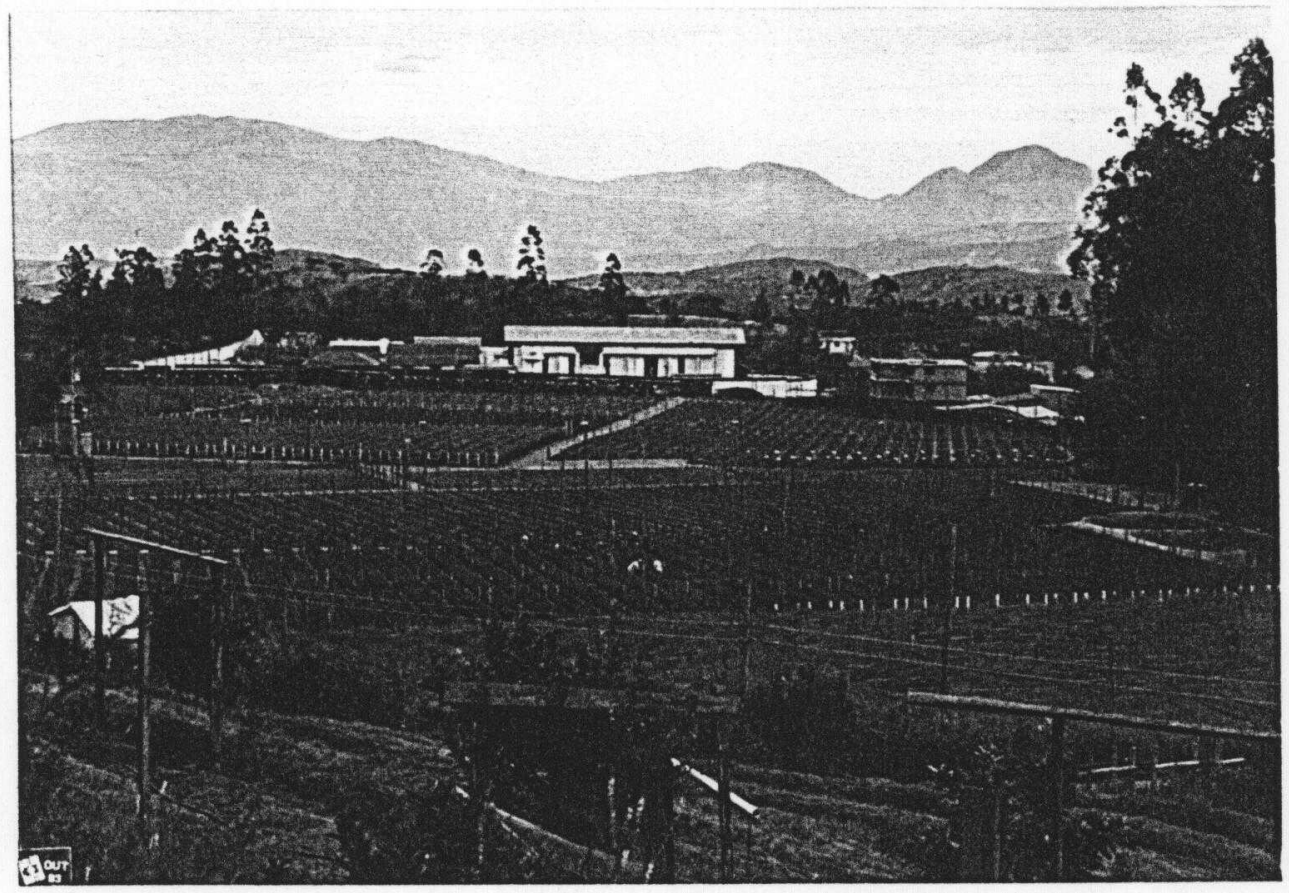




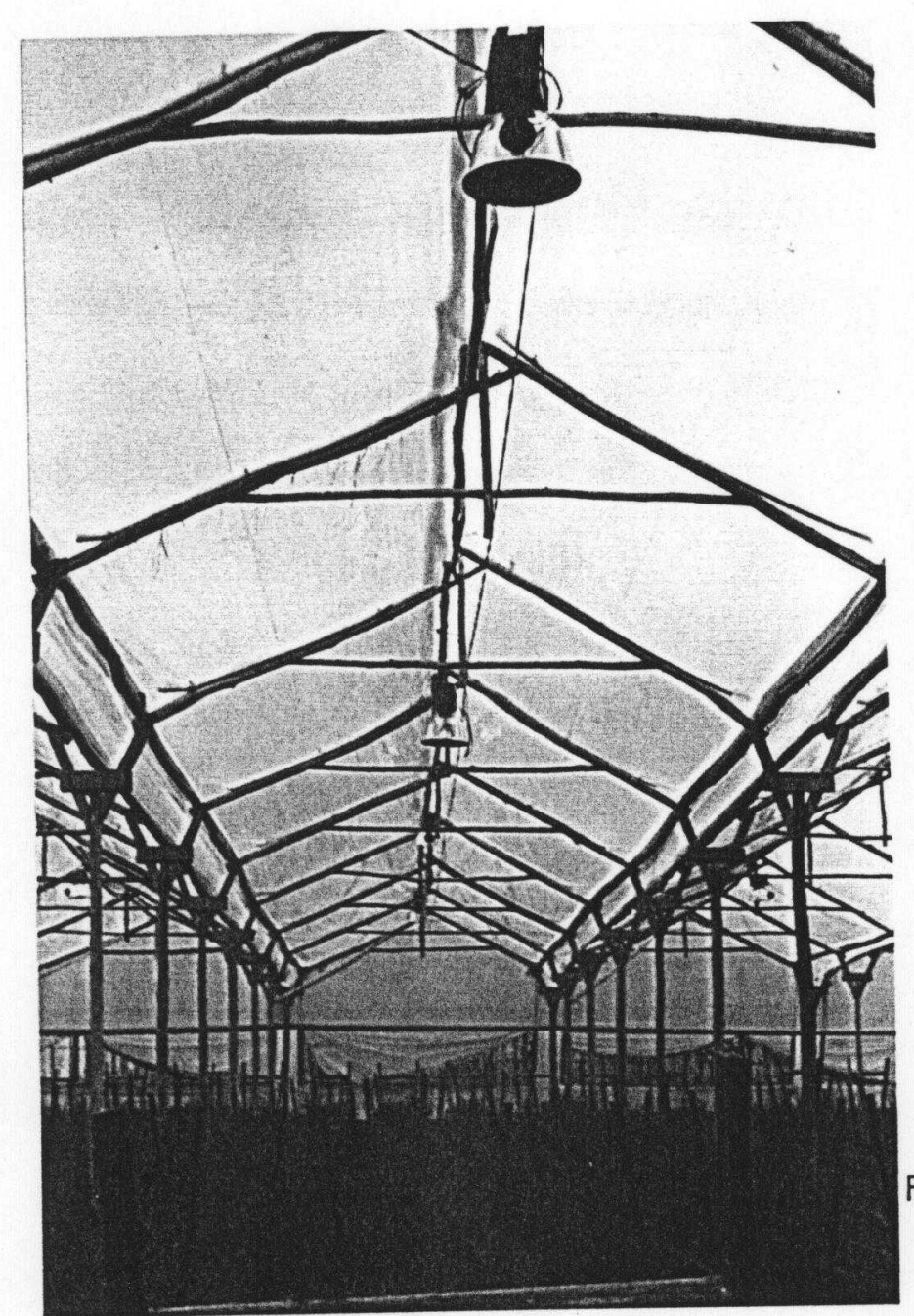

F7 e F8: DISPOSIÇÃO DE LÂMPADAS A VAPOR DE SÓDIO DENTRO DA

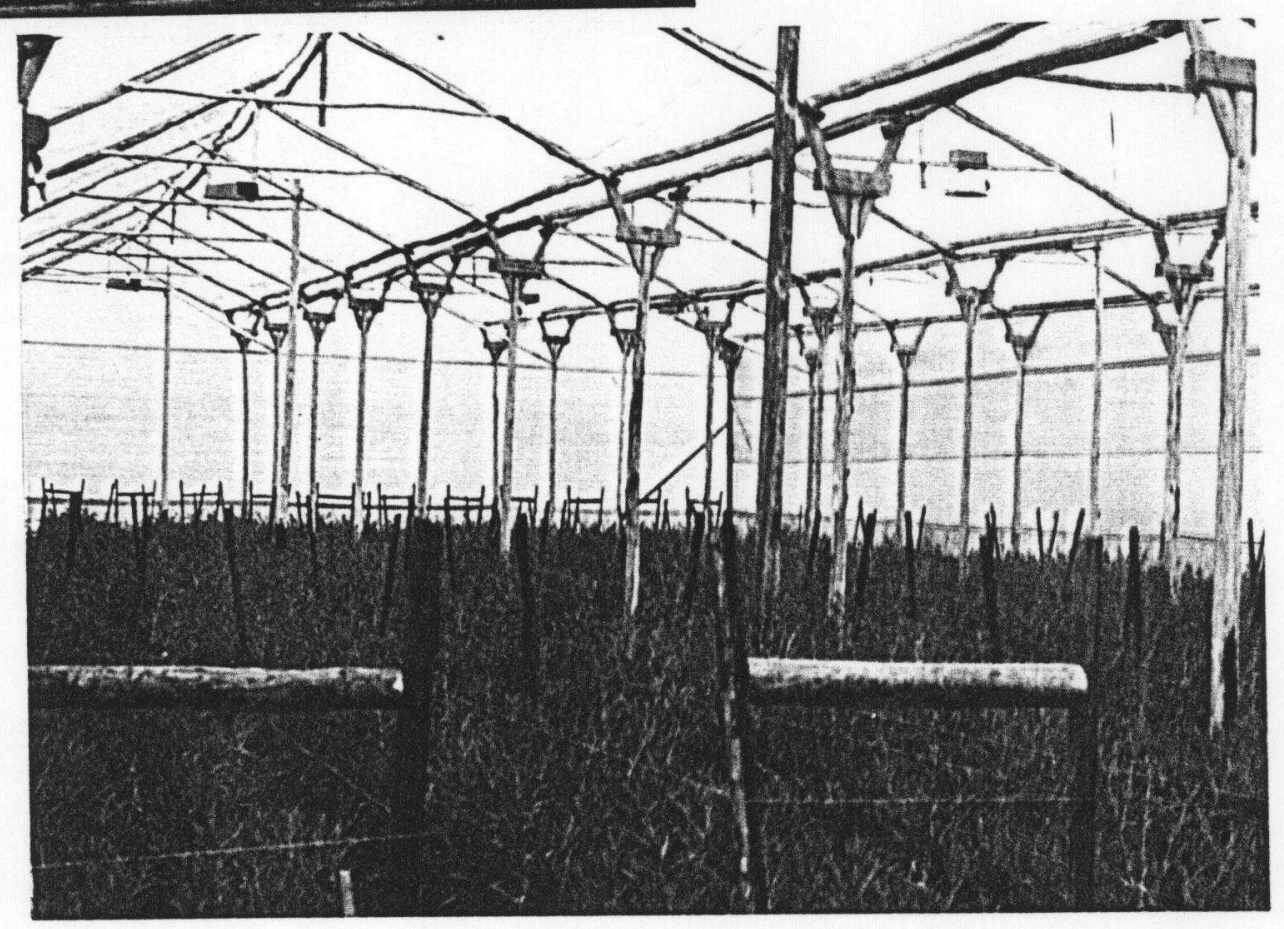




\section{BIBLIOGRAFIA}

ALVES, Marlene Cristina. Irrigação por aspersão convencional, CESP, Ilha Solteira, 1991

ASHRAE HANDBOOK. Refrigeration Systems and Applications, Cooling cut flowers, 1994

ASHRAE. Transactions, Hypobaric Storage of Floral Crops, 1982

ASHRAE HANDBOOK. Refrigeration, Refrigerated Storage Plant Operation, Nursery Stock and Cut Flowers, 1994

BARRAGAN, Javier. Variaciones de presión en laterales portaemisores alimentados por un extremo, por un punto intermedio, o por los dos extremos, Seminário sobre projeto de Irrigação por gotejamento, Universidade de Llerida Espanha, 1993.

BLADIN, Carlos. El clima y sus características en el Ecuador, Asamblea General y reuniones panamericans de consulta anexas, Quito, 1977.

BORRERO, Carlos. Producción y comercialización de flores para corte, Quito, septiembre 19, 1991

CANHAM, A. E. Artificial light in horticulture, Centrex Publishing Company/Eindhoven, 1966.

CESP. Irrigação por gotejo, São Paulo, 1987

CONTI, Laura. Ecologia, Capital, Trabalho e ambiente, São Paulo, 1991.

DOWNS, R. J. Environment and the experimental control of plant growth, Academic press, London, 1975, pag 7-138 
EHRENTREICH, Otto. Câmara frigorífica para estocagem de flores e secagem de bulbos, Revista Abrava, São Paulo, 1980

EMPRESA ELECTRICA REGIONAL NORTE. Catastros de consumo de energia de los años 1989, 1990, 1991, 1993, Dirección Comercial, Ibarra Ecuador.

EMPRESA ELECTRICA REGIONAL NORTE. Despacho de carga de las subestaciones Otavalo y Cayambe, Dirección Técnica, abril 1994, Ibarra Ecuador.

EMPRESA ELECTRICA REGIONAL NORTE. Suministro de potencia y energía del Sistema Nacional Interconectado (DOSNI), Ibarra Ecuador, 1993.

EMPRESA ELECTRICA REGIONAL NORTE. Estadísticas por tipo de servicio, Dirección Comercial, Ibarra Ecuador, 1993.

FONSECA, Jairo Simon. Curso de estatística, São Paulo, 1993

GAUTAM, S. DUTT. Techniques for end-use electricity analysis and conservation program design evaluation a Manual, Volume A. Technical and Economic End-Use Anaysis, The Center for Energy and enviromental studies, Princeton University, June 1992.

GUILLEN, Roberto Andreu. Plantas Vivaces, Valencia, España 1980

HEUSSLER, Peter. Principios fisicos y fisiologicos de la post-cosecha de flores cortadas y su aplicación práctica, Quito, noviembre 1991.

ILUMINATING ENGINEERING SOCIETY OF NORTH AMERICA (IES), LIGHTING HANBOOK. Aplication Volume, New York, 1981, p.(19-31). 
HANBOOK. Aplication Volume, New York, 1993, p.(157-163).

IGLESIAS, José María. Dimensionamiento de ramales de riego por goteo, Artículos Técnicos, Ingeniería Rural, E.U.I.T.A. Lérida, España, 1986.

INSTITUTO NACIONAL DE ESTADISTICAS Y CENSOS. V censo de población y vivienda, Quito 1990.

JONES, Hamlyn G. Plants and microclimate. A quatitative approach to enviromental plant physiology, Cambridge University Press, 1992.

LORDELLO, Antonio Fernando. Métodos de Irrigação, Universidade de São Paulo Escola Superior de Agricultura "Luiz de Queiroz"Departamento de Engenharia Rural, Piracicaba / São Paulo, outubro 1987

LORDELLO, Antonio Fernado. Os métodos de Irrigação, São Paulo, Nobel, 1982.

MORROW. FELICIA, Flowers: Global subsetor study, The World Bank Industry and Energy Department, PPR. Paper N 17, December 1989.

PHILIPS. Manual de alumbrado. Madrid, España, 1983, p.(11-24), p.(215-226)

PHILIPS. Artificial lighting in horticulture, Aplication information, Netherlands, 1989.

RODRIGUEZ. Carlos, Evaluación de instalaciones de microirrigación, Estación de Mecánica Agrícola, Lérida España, 1993.

RUDNICKI. Ryszard M, NOWAK. Joanna, Cold Storage and Transportation conditions for cut flowers cuttings and potted plants, Acta Horticulture, Hortifroid, Fifth Internation Symposium on Postharvest Physiology of Horticulture, Research Institute of Pomology and Floriculture, Poland, 
march, 1991.

SCHOOL OF INDUSTRIAL ENGINEERING AN MANAGEMENT. Energy

Managemente Handbook, Oklahoma State University, 1982.

THRUPP, Lori Ann. Empleo femenino y salud ocupacional, Seminario para Quito, 1992.

WATERS, William F, Desafios en la Agroindustria no tradicional Impactos ambientales y sociales, Memorias de Seminarios-talleres, Quito, 1992. 